\title{
Taxonomic studies of Coronophorales and Niessliaceae (Hypocreomycetidae)
}

\section{Huang SK ${ }^{1,2,3,4,5}$, Hyde $\mathrm{KD}^{3,6^{*}}$, Maharachchikumbura $\mathrm{SSN}^{7}$, McKenzie EHC ${ }^{8}$, Wen TC 1,2,5* $^{*}$}

\author{
${ }^{1}$ State Key Laboratory Breeding Base of Green Pesticide and Agricultural Bioengineering, Key Laboratory of Green \\ Pesticide and Agricultural Bioengineering, Ministry of Education, Guizhou University, Guiyang 550025, China \\ ${ }^{2}$ The Engineering Research Center of Southwest Bio-Pharmaceutical Resources, Ministry of Education, Guizhou \\ University, Guiyang 550025, Guizhou Province, China \\ ${ }^{3}$ Center of Excellence in Fungal Research, Mae Fah Luang University, Chiang Rai 57100, Thailand \\ ${ }^{4}$ School of Science, Mae Fah Luang University, Chiang Rai 57100, Thailand \\ ${ }^{5}$ The Mushroom Research Centre, Guizhou University, Guiyang 550025, China \\ ${ }^{6}$ Innovative Institute of Plant Health, Zhongkai University of Agriculture and Engineering, Haizhu District, Guangzhou \\ 510225, China \\ ${ }^{7}$ School of Life Science and Technology, Center for Informational Biology, University of Electronic Science and \\ Technology of China, Chengdu 611731, China \\ ${ }^{8}$ Manaaki Whenua-Landcare Research, Private Mail Bag 92170, Auckland, New Zealand
}

Huang SK, Hyde KD, Maharachchikumbura SSN, McKenzie EHC, Wen TC 2021 - Taxonomic studies of Coronophorales and Niessliaceae (Hypocreomycetidae). Mycosphere 12(1), 875-992, Doi 10.5943/mycosphere/12/1/9

\begin{abstract}
The number of species in Sordariomycetes has increased dramatically. However, some genera discovered earlier are poorly known, documented and thus need to be redescribed. This paper continues the work on 'Taxonomic studies of some often overlooked Diaporthomycetidae and Sordariomycetidae'. We provide descriptions, notes and figures or drawings for 71 over-looked genera belonging to Bertiaceae, Ceratostomataceae, Chaetosphaerellaceae, Coronophoraceae, Niessliaceae, Nitschkiaceae and Scortechiniaceae in Hypocreomycetidae based on observation of type materials, authentic specimens or studying the literature. The taxonomic placements of the genera are re-defined based on morphology and/or phylogenetic results. As a result, Gonatobotrys and Neotrotteria, which are often overlooked and have unstable taxonomic placements in previous studies, belong to Ceratostomataceae based on morphology and phylogeny. The lichenicolous genus, Nitschkiopsis, which lacks DNA sequence data, is placed in Niessliaceae based on its setose ascomata and hyaline ellipsoidal ascospores similar to Niesslia species. The type species of Cryptosphaerella lacks molecular data and is morphologically similar to Cryptosphaeria or Coronophora, both of which have ostiolate ascomata. Therefore, it is placed in Sordariomycetes, not in Scortechiniaceae, whose species are characterized by ascomata that lack ostioles. In addition, the taxonomy of species with ascomata lacking ostioles in Cryptosphaerella have been revised and introduced as two new genera; Neocryptosphaerella and Pseudocryptosphaerella based on the phylogenetic result. Seven new combinations proposed are Fracchiaea myricoides (三 Coronophora myricoides), Neocryptosphaerella celata (三Cryptosphaerella celata), N. globosa (三Cry. globosa), Pseudocryptosphaerella costaricensis ( $\equiv$ Cry. costaricensis), P. cylindriformis (三 Cry. cylindriformis), P. elliptica (三Cry. elliptica) and P. malindensis (三Cry. malindensis).
\end{abstract}


Keywords - 9 new taxa - Bertiaceae - Ceratostomataceae - Chaetosphaerellaceae Coronophoraceae - Nitschkiaceae - Scortechiniaceae - Niessliaceae

\section{Introduction}

An increase in fungal taxonomic studies over the last decade has led to the discovery of numerous new taxa and the revision of extant taxa, and subsequently, this has resulted in a better understanding of fungal classification (Hyde et al. 2020d, Maharachchikumbura et al. 2021). More than 100 taxa in Sordariomycetes, such as Chaetomium, Humicola, Podospora, Thielavia and Zopfiella species, have been repositioned based on molecular data (Wang et al. 2016, 2019a, b, Vu et al. 2019, Marin-Felix et al. 2020, Hyde et al. 2020e, Huang et al. 2021), while, many new species have been introduced based on morphology and phylogenetic analyses. This data is scattered in many publications, and information is available on various webpages (Pem et al. 2019a, Calabon et al. 2020, Bundhun et al. 2020, Hyde et al. 2020a, Wijesinghe et al. 2021).

A major problem in fungal classification, however, is the number of genera that have not been studied in recent decades (Dayarathne et al. 2016, Huang et al. 2021). Many have very brief descriptions and no drawing or photos (Saccardo 1873b, 1880, 1882a, 1886, Penzig \& Saccardo 1897, Boudier 1904), and therefore it is tough to place these taxa in a classification scheme. As more studies have taken place in the tropics and researchers rely on poorly documented genera from the northern hemisphere, it is extremely hard to link new collections to old names. Similarly, sequence data for many old northern hemisphere genera are lacking (Berkeley 1875, 1876, Ellis \& Everhart 1892, Lundqvist 1972), and new collections from the tropics with sequence data cannot be linked to the extant genera. The trend to introduce additional new taxa, however, is not hindered despite progress in the discovery of many new species from China and Thailand (Hyde et al. 2019, 2020b, c, Jayawardena et al. 2018, Wanasinghe et al. 2018, Hapuarachchi et al. 2019, Luo et al. 2019, Pem et al. 2019b, Phookamsak et al. 2019, Yuan et al. 2020).

Several previous studies have contributed DNA sequence data and taxonomic illustrations of earlier published taxa. This information has helped to clarify the placement of these taxa (Wang et al. 2016, 2019a, b, 2020, Marin-Felix et al. 2020). For example, the polyphyletic Lasiosphaeriaceae with cylindrical to pod-like ascospores was divided into nine families, Bombardiaceae, Diplogelasinosporaceae, Lasiosphaeriaceae, Lasiosphaeridaceae, Naviculisporaceae, Neoschizotheciaceae, Podosporaceae, Strattoniaceae and Zygospermellaceae, based on phylogenetic analyses (Wang et al. 2019a, Vu et al. 2019, Marin-Felix et al. 2020, Huang et al. 2021). The difference between Neurospora and Sordaria was clarified with the ascospores of the former having pitted or ribbed walls and those of the latter being smooth-walled (Cai et al. 2006, Huang et al. 2021). Several Cercophora species having ellipsoidal to triangular ascospores were assigned to Cladorrhinum, Mammaria, Podospora and Triangularia and this taxonomic arrangement was supported by phylogenetic results (Marin-Felix et al. 2020, Huang et al. 2021). Wang et al. (2020) sequenced and analysed additional taxa from the Cordycipitaceae but the affinities and taxonomic placement of many taxa still need to be investigated.

An important class, Sordariomycetes was introduced by Eriksson \& Winka (1997). Many poorly known taxa were initially classified to this class based on morphology (Barr 1983, 1990, Eriksson \& Hawksworth 1993, Lumbsch \& Huhndorf 2007, Hyde et al. 2020e). Hypocreomycetidae was listed in Sordariomycetes and previously accommodated Coronophorales, Hypocreales, Melanosporales and Microascales (Huhndorf et al. 2004b, Lumbsch \& Huhndorf 2007). Subsequently, Conioscyphales, Falcocladiales, Glomerellales, Pleurotheciales, Savoryellales and Torpedosporales were also placed in this subclass based on morphology and phylogenetic results (Jones et al. 2015, Maharachchikumbura et al. 2015, 2016). Parasympodiellales was initially treated as a member of Sordariomycetes (Hernández-Restrepo et al. 2017), and Hyde et al. (2020e) accepted this order in Hypocreomycetidae based on the divergent time estimates. Members of the Conioscyphales, Fuscosporellales, Pleurotheciales and Savoryellales clustered as a distinct, independent clade Savoryellomycetidae (Hongsanan et al. 2017). Therefore, there are currently seven orders, viz Coronophorales, Falcocladiales, Glomerellales, Hypocreales, Microascales, 
Parasympodiellales and Torpedosporales included in Hypocreomycetidae and its divergence time has been estimated as 256 MYA (Hyde et al. 2020e).

Coronophorales is a poorly known order, which has turbinate or globose ascomata with long necks or Quellkörper structures and/or Munk pores in the cells of the ascoma wall (Mugambi et al. 2010, Carneiro de Almeida et al. 2016), and is found on woody substrates worldwide (Mugambi \& Huhndorf 2010, Maharachchikumbura et al. 2016, Hyde et al. 2020e). Several members of this order were initially placed in Sordariales (Nannfeldt 1932, 1975, Müller \& von Arx 1973, Nannfeldt \& Santesson 1975, Barr 1990, Subramanian \& Sekar 1990). However, Huhndorf et al. (2004b) clarified the affinities of Coronophorales based on phylogenetic analyses and subsequently, this order contained six families, Bertiaceae, Ceratostomataceae, Chaetosphaerellaceae, Coronophoraceae, Nitschkiaceae and Scortechiniaceae (Nannfeldt 1975, Subramanian \& Sekar 1990, Mugambi \& Huhndorf 2010, Maharachchikumbura et al. 2015, 2016, Hyde et al. 2017, 2020e). The taxa in Ceratostomataceae usually have long-necked ascomata and ellipsoidal to broadly fusiform ascospores (Marin-Felix et al. 2018, Hyde et al. 2020e). Bertiaceae, Chaetosphaerellaceae, Coronophoraceae and Nitschkiaceae have black, tuberculate ascomata with ostioles or lacking ostioles, but have obconical Quellkörper structures (Saccardo 1882a, Patouillard \& Lagerheim 1895, Subramanian \& Sekar 1990, Réblová 1999a, b). Scortechiniaceae is mainly characterized by Quellkörper structures in the turbinate ascomata and allantoid to ellipsoidal ascospores (Huhndorf et al. 2004b).

Hypocreales, as the largest order in Hypocreomycetidae, is common silvicolous fungi with a worldwide distribution (Rehner \& Samuels 1995, Rossman et al. 1999, Maharachchikumbura et al. 2016). Hyde et al. (2020e) listed 14 families of the order. Some of them with medicinal and edible values are often mentioned in recent studies, such as Ophiocordycipitaceae and Cordycipitaceae (Quandt et al. 2014, Kepler et al. 2017). However, the saprobic Niessliaceae, as an earlier member, has rarely been mentioned over the past decade (Tang et al. 2007, Lombard et al. 2015, Maharachchikumbura et al. 2016, Hyde et al. 2020e). This family usually has membranaceous ascomata with setae or hairs and ellipsoidal to filiform ascospores and accommodates 21 genera, but many members lack sequence data (Rehner \& Samuels 1995, Samuels \& Barr 1997, Rossman et al. 1999, Maharachchikumbura et al. 2016, Hyde et al. 2020e).

In this study, we revisit rarely mentioned taxa in Coronophorales and Niessliaceae. Most of them were found many years ago and lack detailed descriptions, photoplates and molecular data. These facts make it hard to recognize and demarcate species, and it is not easy to compare them with new collections in subsequent studies. Therefore, we re-examine the type material and/or authentic specimens together with the literature of the taxa in Coronophorales and Niessliaceae and provide illustrations and descriptions. Morphology and phylogenetic analyses are used to determine their affinities and taxonomic placement.

\section{Materials \& Methods}

\section{Material examination}

Specimens were loaned from BPI, BR, CUP, F, FH, G, HBG, IMI, MAF, NY, PC, PDD, PRM, S, TRTC, UPS and W herbaria\#. Examination of specimens was done following the method of Senanayake et al. (2020). Samples were observed in pure water and/or 5\% KOH reagent for sectioning; sometimes, they were stained in Congo red or cotton blue to observe the reaction. Specimens were examined using a Motic SMZ 168 stereomicroscope. Micromorphological

\footnotetext{
\# Institution: BPI: U.S. National Funngus Collections, USDA-ARS, USA; BR: Meise Botanic Garden, Belgium; CUP: Cornell University, USA; F: Field Museum of Natural History, USA; FH: Harvard University, USA; G: Conservatoire et Jardin botaniques de la Ville de Genève, Switzerland; HBG: University of Hamburg, Germany; IMI: CABI Bioscience UK Centre, UK; MAF: Facultad de Farmacia, Universidad Complutense, Madrid, Spain; NY: The New York Botanical Garden, USA; PC: Muséum National d'Histoire Naturelle, France; PDD: Manaaki Whenua - Landcare Research, New Zealand; PRM: National Museum, Czech Republic; S: Swedish Museum of Natural History, Sweden; TRTC: Royal Ontario Museum, Canada; UPS: Museum of Evolution, Sweden; W: Naturhistorisches Museum Wien, Austria.
} 
characters were examined using a Nikon ECLIPSE 80i compound microscope, and images were captured with a Canon EOS 550D and/or a Canon EOS 600D digital camera. Taro soft ® Image Framework program version 0.9.0.7 was used for measurements. Some of the type specimens were in poor condition or could not be loaned. For these taxa, we redrew the morphological features based on the original publications. The images used for photoplates were processed with Adobe Photoshop CS6 software (Adobe Systems, USA).

\section{Phylogenetic analyses}

Sequences were obtained from GenBank mostly following previous publications and aligned by using the default settings of MAFFT version 7 (http://mafft.cbrc.jp/alignment/server/index.html) (Katoh \& Standley 2013). These datasets were manually aligned using Bioedit 7.0.9.0 (Hall 1999). The phylogenetic analyses of the combined the nuclear ribosomal large subunit (LSU), nuclear ribosomal small subunit (SSU), internal transcribed spacer (ITS), translation elongation factor (TEF), RNA polymerase II (RPB2) and beta-tubulin (TUB) sequence data were performed using maximum-likelihood (ML) and Bayesian inference (BI). The evolutionary model was obtained using jModeltest 2.1.1 under the Akaike information criterion (AIC) (Darriba et al. 2012). The selected models which are not implemented in MrBayes were substituted by the closest overparameterized model (Huelsenbeck \& Rannala 2004). The TIM2, TIM3, TrN and TrNef models were replaced by the GTR model (Lecocq et al. 2013). The proportion of invariable sites (I) and gamma distributed rates $(\mathrm{G})$ assured in jModeltest were conserved in all models. The ML analyses were run with IQ-TREE (Nguyen et al. 2015, Chernomor et al. 2016), using models for each partitioned gene, with 1000 rapid bootstrap replicates. BI was implemented by MrBayes v.3.0b4 (Ronquist \& Huelsenbeck 2003) with the best-fit model of sequence evolution. Phylogenetic tree was viewed with FigTree v1.4.0 (http://tree.bio.ed.ac.uk/software/figtree/) and processed by Adobe Illustrator CS5. The final alignment and trees were deposited in TreeBASE.

Table of contained information of genera in Coronophorales and Niessliaceae in Hypocreomycetidae. Those not in agreement with Wijayawardene et al. 2020 are marked with an asterisk $(*)$.

Phylum Ascomycota Caval.-Sm.

Class Sordariomycetes O.E. Erikss. \& Winka

Subclass Hypocreomycetidae O.E. Erikss. \& Winka

Coronophorales Nannf.

Bertiaceae Smyk

Bertia De Not.

Gaillardiella Pat.

Ceratostomataceae G. Winter

Arxiomyces P.F. Cannon \& D. Hawksw.

Dactylidispora Y. Marín et al.

Echinusitheca Y. Marín et al.

Erythrocarpon Zukal

Gonatobotrys Corda 1839*

Harzia Costantin

Melanospora Corda

Microthecium Corda

Neotrotteria Sacc.*

Pseudomicrothecium Y. Marín et al.

Pustulipora P.F. Cannon

Rhytidospora Jeng \& Cain

Scopinella Lév.

Setiferotheca Matsush. 
Syspastospora P.F. Cannon \& D. Hawksw.

Vittatispora P. Chaudhary et al.

Chaetosphaerellaceae Huhndorf et al.

Chaetosphaerella E. Müll. \& C. Booth

Crassochaeta Réblová

Neochaetosphaerella Lar.N. Vassiljeva et al.

Spinulosphaeria Sivan.

Coronophoraceae Höhn.

Coronophora Fuckel

Nitschkiaceae (Fitzp.) Nannf.

Acanthonitschkea Speg.

Biciliosporina Subram. \& Sekar

Botryola Bat. \& J.L. Bezerra

Fracchiaea Sacc.

Groenhiella Jørg. Koch et al.

Janannfeldtia Subram. \& Sekar

Lasiosphaeriopsis D. Hawksw. \& Sivan.

Loranitschkia Lar.N. Vassiljeva

Nitschkia G.H. Otth ex P. Karst.

Rhagadostoma Körb.

Rhagadostomella Etayo

Tortulomyces Lar.N. Vassiljeva et al.

Scortechiniaceae Huhndorf et al.

Biciliospora Petr.

Coronophorella Höhn.

Euacanthe Theiss.

Neocryptosphaerella S.K. Huang \& K.D. Hyde *

Neofracchiaea Teng

Pseudocatenomycopsis Crous \& L.A. Shuttlew.

Pseudocryptosphaerella S.K. Huang \& K.D. Hyde *

Scortechinia Sacc.

Scortechiniella Arx \& E. Müll.

Scortechiniellopsis Sivan.

Tympanopsis Starbäck

Hypocreales Lindau

Niessliaceae Kirschst.

Atronectria Etayo

Circinoniesslia Samuels \& M.E. Barr

Cryptoniesslia Scheuer

Eucasphaeria Crous

Malmeomyces Starb.

Melchioria Penz. \& Sacc.

Miyakeomyces Hara

Myrmaeciella Lindau

Myrtacremonium Crous

Neoeucasphaeria Crous

Niesslia Auersw.

= Hyaloseta A.W. Ramaley*

Nitschkiopsis Nannf. \& R. Sant.*

Paraniesslia K.M. Tsui et al.

Pseudohyaloseta Tibpromma \& K.D. Hyde 
Pseudonectriella Petr.

Pseudorhynchia Höhn.

Rosasphaeria Jaklitsch \& Voglmayr

Taiwanascus Sivan \& H.S. Chang

Trichosphaerella E. Bommer et al.

Valetoniella Höhn.

Valetoniellopsis Samuels \& M.E. Barr

\section{Other genera in Hypocreomycetidae}

Glomerellales genera incertae sedis

Ascocodinaea Samuels, Cand. \& Magni

Torpedosporales E.B.G. Jones, Abdel-Wahab \& K.L. Pang

Etheirophoraceae Rungjind., Somrith. \& Suetrong

Etheirophora Kohlm. \& Volkm.-Kohlm.

Swampomyces Kohlm. \& Volkm.-Kohlm.

Juncigenaceae E.B.G. Jones, Abdel-Wahab \& K.L. Pang

Juncigena Kohlm., Volkm.-Kohlm. \& O.E. Erikss.

Sordariomycetes genera incertae sedis

Cryptosphaerella Sacc.*

Hypocreomycetidae O.E. Erikss. \& Winka, Myconet 1(1): 6 (1997)

Eriksson \& Winka (1997) introduced the subclass Hypocreomycetidae closely related to Savoryellomycetidae based on phylogenetic results (Hongsanan et al. 2017). There are six orders in this subclass viz. Coronophorales, Falcocladiales, Glomerellales, Hypocreales, Microascales, Torpedosporales (Wijayawardene et al. 2020) and most contain species as saprobes in aquatic and/or terrestrial habitats (Maharachchikumbura et al. 2016, Hyde et al. 2020e).

Coronophorales Nannf., Nova Acta R. Soc. Scient. upsal., Ser. 4 8(no. 2): 54 (1932)

The genera in Coronophorales have a worldwide distribution as saprobes on wood and are characterized by superficial ascomata, sometimes with a subiculum, Quellkörper (a mucilaginous mass of thick-walled cells as conical structure within the cupulate or collapsed ascoma, believed to induce rupture of the ascoma and release ascospores) and Munk pores (a small pore with annular thickened rim, between cells of the ascoma wall) (Mugambi \& Huhndorf 2010). Asci are clavate to subglobose with subcylindrical to ellipsoidal ascospores and asexual morphs are usually hyphomycetous and phialidic (Mugambi \& Huhndorf 2010, Maharachchikumbura et al. 2016, Hyde et al. 2020e). This order was considered as a synonym of Nitschkiaceae and Sordariales (Barr 1990, Müller \& von Arx 1973, Nannfeldt 1932, Nannfeldt \& Santesson 1975, Subramanian \& Sekar 1990). However, multi-gene analyses were used to show that Coronophorales which accommodates Bertiaceae, Ceratostomataceae, Chaetosphaerellaceae, Coronophoraceae, Nitschkiaceae and Scortechiniaceae is distinct, and is sister to Falcocladiales in Sordariomycetidae (Hongsanan et al. 2017, Huang et al. 2021, this study, Fig. 1).

Bertiaceae Smyk, Ukr. bot. Zh. 38(6): 47 (1981)

Saprobic on wood. Sexual morph: Subiculum inconspicuous or composed of brown to dark brown, branched, septate hyphae. Ascomata solitary or gregarious, superficial to erumpent, usually sitting on a subiculum, cupuliform, turbinate, globose to subglobose, carbonaceous to membranaceous, dark brown to black, tuberculate or smooth, collapsing, collapsing laterally or not collapsing, with ostioles or a papillate ostiole-like structure, without an external opening, periphysate, Quellkörper absent. Peridium composed of carbonaceous to membranaceous, dark 
brown, brown to hyaline cells of textura angularis to textura prismatica, mostly Munk pores present. Paraphyses few, inflated, branched. Asci 8-spored, unitunicate, cylindrical to clavate, long pedicellate, apical ring indistinct or absent. Ascospores 2-3-seriate or irregularly arranged, hyaline to brown, ellipsoidal to fusiform, 0 to multi-septate, smooth-walled, mostly with guttules. Asexual morph: Undetermined (adapted from Patouillard \& Lagerheim 1895, Mugambi \& Huhndorf 2010, Maharachchikumbura et al. 2015, Hyde et al. 2020e).

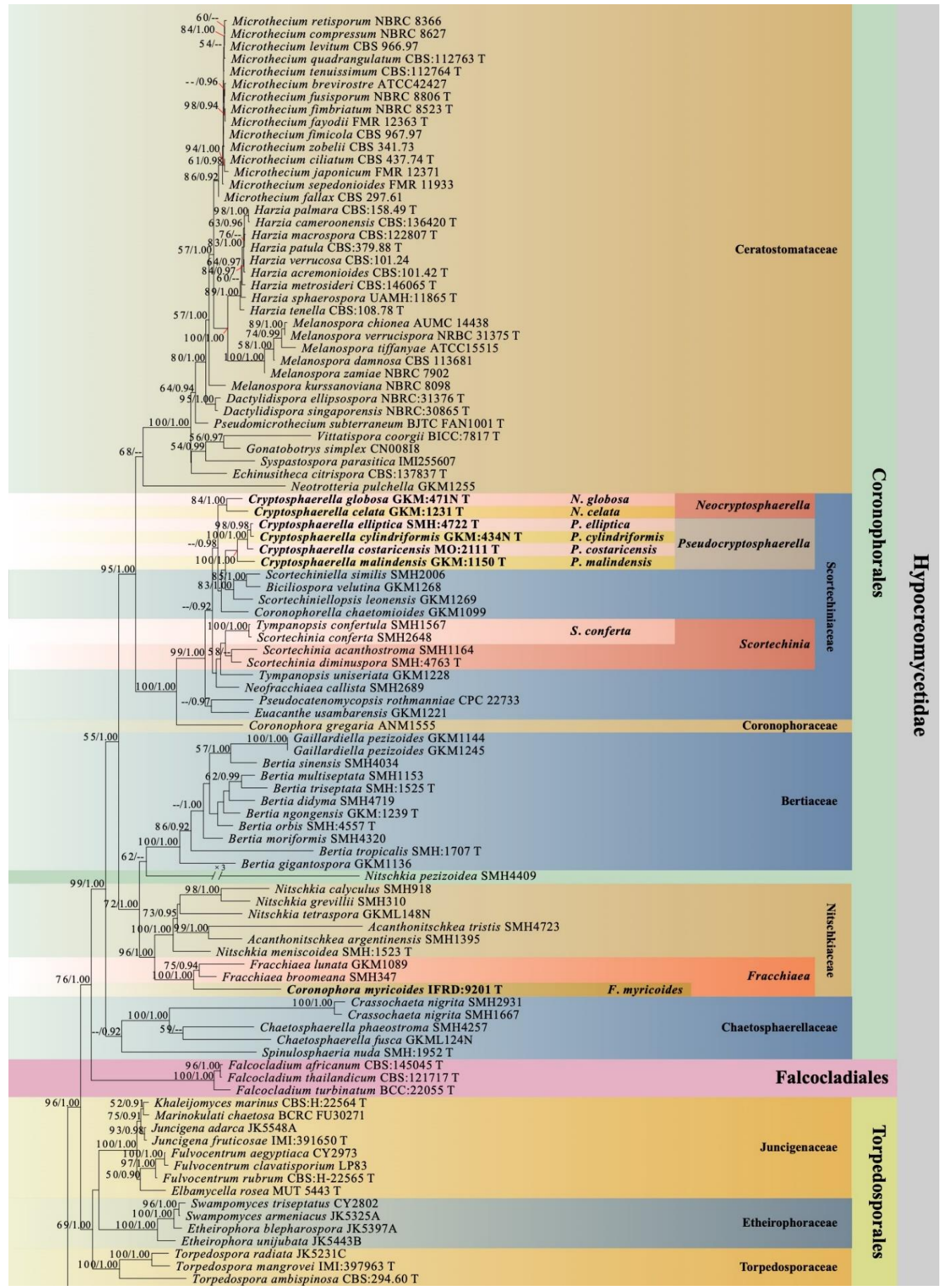

Figure 1 - Phylogram generated from maximum likelihood analysis based on combined LSU, SSU, TEF, RPB2, TUB and ITS sequence data with the confidence values of bootstrap (BS) proportions from the Maximum Likelihood (ML) analysis (ML-BS > 50\%, before the backslash) and the posterior probabilities (PP) from the Bayesian (BY) analysis (BY-PP $>0.90$, after the backslash) above corresponding nodes. The '--' indicates a lack of statistical support $(<50 \%$ for ML-BS and $<0.90$ for BY-PP). One hundred and ninety-eight strains are included in the combined 
analyses which comprised 4581 characters (842 characters for LSU, 1025 characters for SSU, 950 characters for TEF, 876 characters for RPB2, 391 characters for TUB, 497 characters for ITS) after alignment. Strains of Xylariomycetidae are used as outgroup taxa. The best score in IQ-TREE explores with a final likelihood value of -90984.2293 is presented. The model of each partitioned gene is LSU: GTR+I+G; SSU: GTR+G; TEF: GTR+I+G; RPB2: GTR+I+G; TUB: GTR+I+G; ITS: GTR+G. Sequences generated indicated in bold. Strain numbers are noted after the species names and ex-type strains marked with ' $\mathrm{T}$ ' after the culture number. Alignment is available at TreeBASE (URL: http://purl.org/phylo/treebase/phylows/study/TB2:S28271).

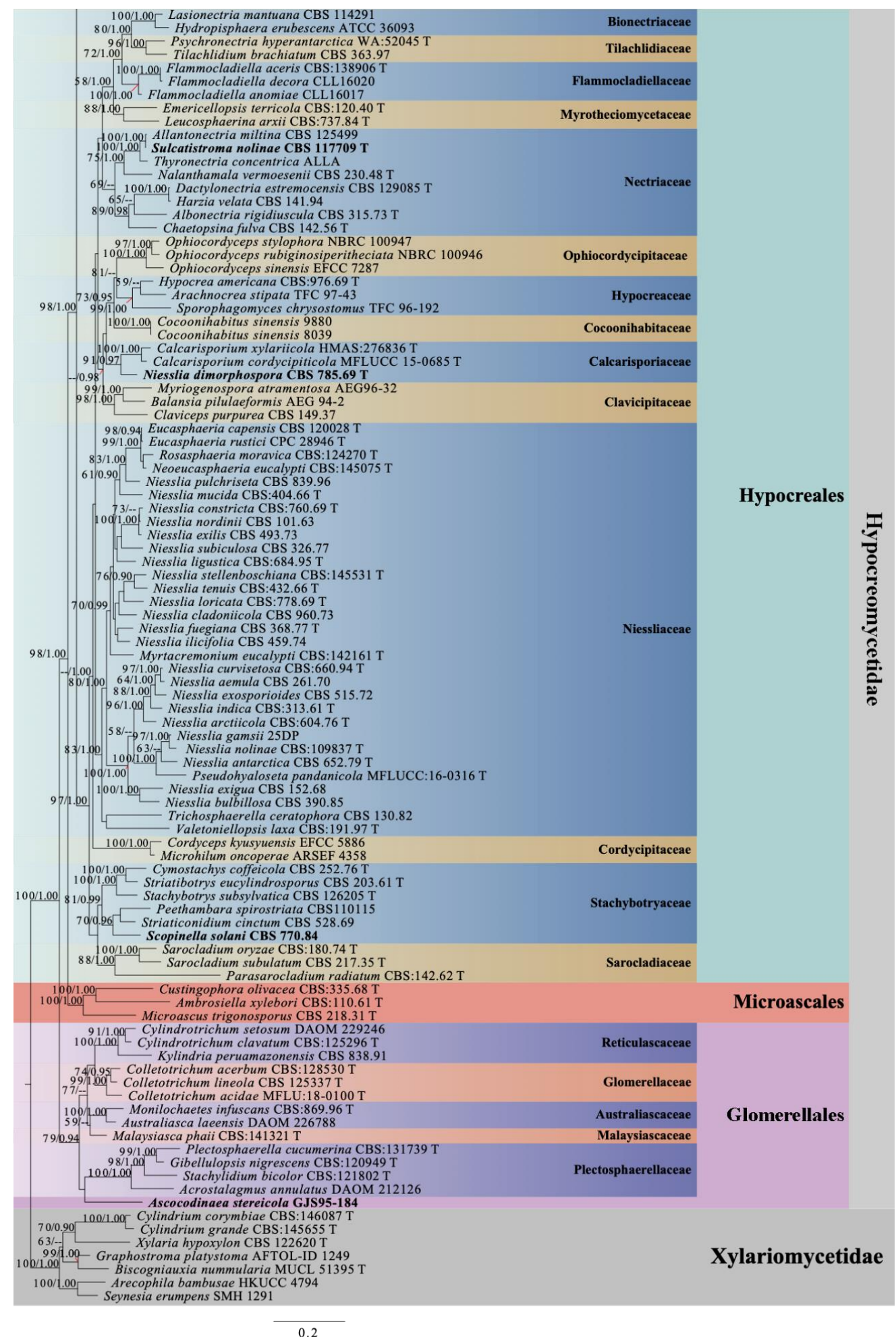

Figure 1 - Continued. 
Type genus - Bertia De Not.

Notes - Smyk (1981) introduced the family Bertiaceae and initially included Bertia which has tuberculate ascomata and fusiform ascospores. Subsequently, Mugambi \& Huhndorf (2010) reevaluated the Coronophorales and transferred the genus Gaillardiella to Bertiaceae based on multigene analysis. Therefore, Bertia and Gaillardiella were confirmed as members of Bertiaceae, and they have tuberculate ascomata, cylindrical to clavate asci and ellipsoidal to fusiform ascospores (Huhndorf et al. 2004b, Mugambi \& Huhndorf 2010). In this study, strains of these two genera clustered with 100\% ML/1.00BY support and are closely related to Nitschkiaceae (Fig. 1).

Bertia De Not., G. bot. ital. 1(1): 334 (1844)

Saprobic on wood. Sexual morph: Subiculum inconspicuous or composed of brown to dark brown, branched, septate hyphae. Ascomata solitary or gregarious, superficial to erumpent, usually sitting on a subiculum, cupuliform, turbinate, globose to subglobose, carbonaceous to membranaceous, dark brown to black, tuberculate or smooth, collapsing, collapsing laterally or not collapsing, with ostioles or a papillate ostiole-like structure, without an external opening, periphysate. Peridium carbonaceous or membranaceous, outer layer composed of dark brown to brown cells of textura angularis, Munk pores present; inner layer composed of hyaline cells of textura prismatica. Paraphyses few, inflated, branched. Asci 8-spored, unitunicate, cylindrical to clavate, long pedicellate, apical ring indistinct or absent. Ascospores 2-3-seriate or irregularly arranged, hyaline to brown, ellipsoidal to fusiform, 0 to multi-septate, smooth-walled, mostly with guttules. Asexual morph: Undetermined (adapted from Mugambi \& Huhndorf 2010, Maharachchikumbura et al. 2015, Hyde et al. 2020e).

Notes - Bertia is typified by B. moriformis and its species mostly have tuberculate ascomata and hyaline ascospores (De Notaris 1844, Mugambi \& Huhndorf 2010). It is closely related to members of Nitschkiaceae based on multi-gene analyses (Huhndorf et al. 2004b, Mugambi \& Huhndorf 2010, Maharachchikumbura et al. 2015, Hyde et al. 2020e, Fig. 1).

Bertia moriformis (Tode) De Not., G. bot. ital. 1(1): 335 (1844)

Fig. 2

Basionym - Sphaeria moriformis Tode, Fung. mecklenb. sel. (Lüneburg) 2: 22 (1791)

Facesoffungi number: FoF 01113

Saprobic on decorticated branches. Sexual morph: Ascomata $0.7-1 \times 0.4-0.8 \mathrm{~mm}(\bar{x}=0.8 \times$ $0.6 \mathrm{~mm}, \mathrm{n}=10$ ), scattered to gregarious, superficial or erumpent through the surface of the host, globose to subglobose, dark brown to black, carbonaceous, tuberculate, collapsing laterally or not collapsing, with a short papillate ostiole-like structure, without an external opening, periphysate. Peridium 90-250 $\mu \mathrm{m}$, comprising three layers, outer layer composed of dark tissues, carbonaceous; middle layer composed of membranaceous, dark brown to brown cells of textura angularis, Munk pores present; inner layer composed of membranaceous, hyaline cells of textura prismatica. Paraphyses 9-13 $\mu \mathrm{m}$ wide, few, inflated, branched. Asci (120-)140-155(-180) $\times(13-) 15-20(-23)$ $\mu \mathrm{m}(\bar{x}=148 \times 18 \mu \mathrm{m}, \mathrm{n}=30), 8$-spored, unitunicate, clavate, with long tapering pedicel, apical ring absent. Ascospores (22-)25-35(-40) $\times(3-) 5-7(-9) \mu \mathrm{m}(\bar{x}=30 \times 6.5 \mu \mathrm{m}, \mathrm{n}=50), 2-3$-seriate or irregularly arranged, hyaline to pale brown, cylindrical to fusiform, 0-1-septate, slightly curved, smooth-walled, with guttules. Asexual morph: Undetermined.

Material examined - Italy, Riva Valdobbia, on decorticated branch of Rhododendron sp. (Ericaceae), 30 April 1859, Carestia (S-F298).

Known hosts and distribution - on decayed wood in Germany (type locality), Italy and USA (Tode 1791, Huhndorf et al. 2004b).

Notes - Sphaeria moriformis was collected in Germany in March or April 1790 (Tode 1791). De Notaris (1844) established Bertia based on S. moriformis. We were unable to obtain the type material but re-examined a specimen collected in Italy in 1859 . This sample is similar to $B$. moriformis described by Tode (1791), which has gregarious, oval, tuberculate ascomata and fusiform ascospores. Bertia species aggregate into a cluster based on phylogenetic result with 100\% ML/1.00BY support (Fig. 1). 

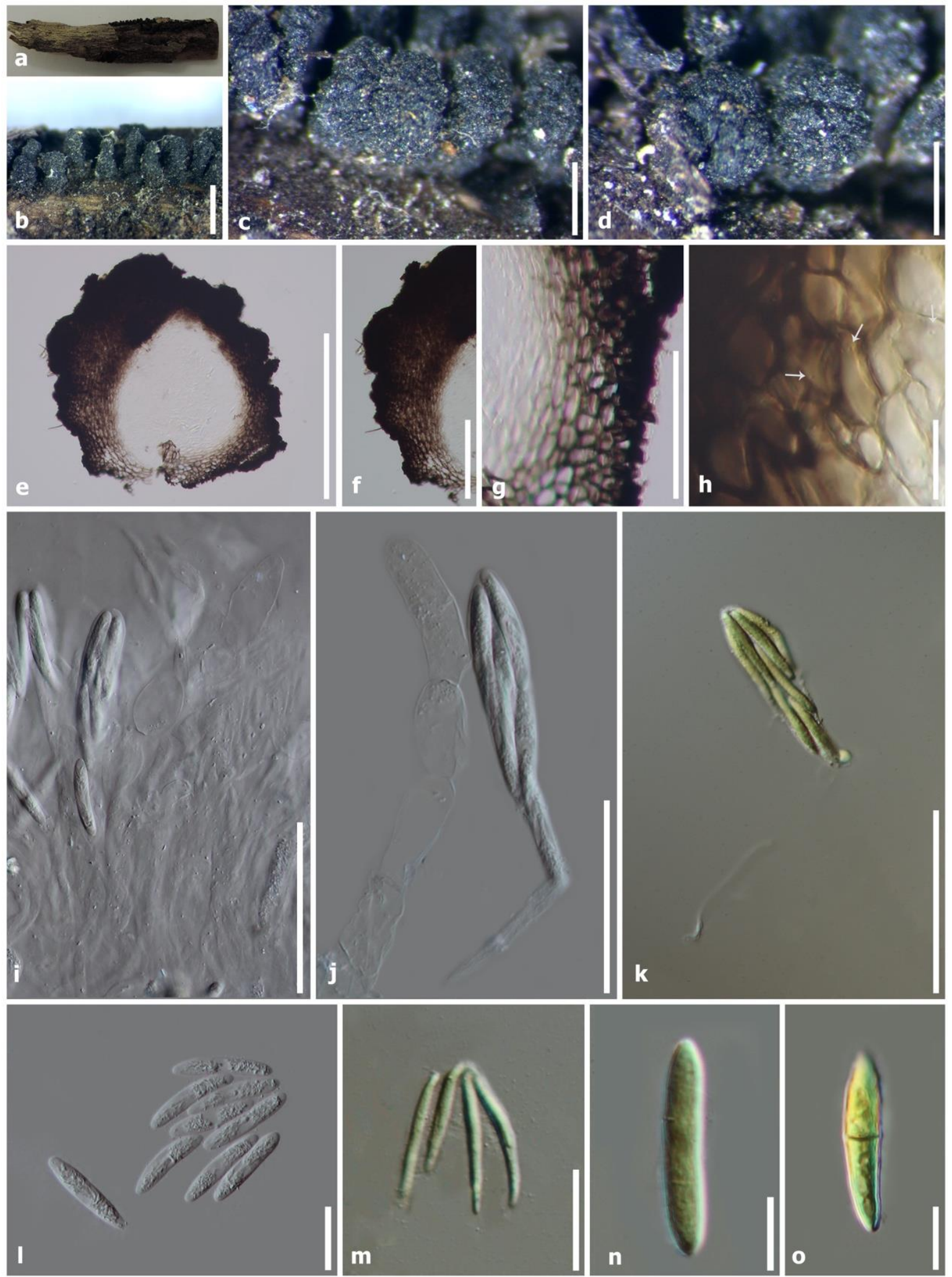

Figure 2 -Bertia moriformis: (S-F298). a Material. b-d Ascomata on the host. e Ascoma in cross section. f-g Peridium. h Wall cells with Munk pores (arrows). i-k Asci with inflated paraphyses. 1-o Ascospores. Notes: $\mathrm{k}, \mathrm{m}-\mathrm{O}$ stained in Melzer's reagent. Scale bars: $\mathrm{b}=1 \mathrm{~mm}, \mathrm{c}-\mathrm{e}=500 \mu \mathrm{m}$, $\mathrm{f}=200 \mu \mathrm{m}, \mathrm{g}=100 \mu \mathrm{m}, \mathrm{i}-\mathrm{k}=50 \mu \mathrm{m}, \mathrm{h}, \mathrm{l}-\mathrm{m}=20 \mu \mathrm{m}, \mathrm{n}-\mathrm{o}=10 \mu \mathrm{m}$.

Gaillardiella Pat., in Patouillard \& Lagerheim, Bull. Soc. mycol. Fr. 11(4): 226 (1895)

Saprobic on wood. Sexual morph: Ascomata gregarious, superficial to erumpent, globose to subglobose, coriaceous, dark brown to black, tuberculate, glabrous, collapsing or not, with ostioles 
or a short papillate ostiole-like structure, without an external opening. Peridium composed of coriaceous to membranaceous, brown to hyaline cells of textura angularis to textura prismatica, sometimes with Munk pores. Paraphyses filiform. Asci 8-spored, unitunicate, cylindrical to clavate, long pedicellate, apical ring indistinct or absent. Ascospores 2-3-seriate or irregularly arranged, hyaline to brown, ellipsoidal to clavate, $0-1$-septate, smooth-walled, mostly with guttules. Asexual morph: Undetermined (adapted from Patouillard \& Lagerheim 1895, Mugambi \& Huhndorf 2010).

Notes - Gaillardiella was placed in Bertiaceae because it has tuberculate ascomata and ellipsoidal to fusiform ascospores similar to Bertia, and its generic type, G. pezizoides, nests with Bertia based on phylogenetic results (Patouillard \& Lagerheim 1895, Huhndorf et al. 2004b, Mugambi \& Huhndorf 2010, Fig. 1).

Gaillardiella pezizoides Pat., in Patouillard \& Lagerheim, Bull. Soc. mycol. Fr. 11(4): 226 (1895)

Facesoffungi number: FoF 10053

Fig. 3

Saprobic on decorticated branches. Sexual morph: Subiculum composed of brown to dark brown, branched, septate hyphae. Ascomata 300-550 $\mu \mathrm{m}$ diam., superficial, sitting on thin subiculum, scattered to gregarious, coriaceous, black, cupuliform, tuberculate, glabrous, collapsing laterally, with a short, papillate ostiole-like structure, without an external opening. Peridium 150$200 \mu \mathrm{m}$ thick, comprising two layers, outer layer composed of coriaceous, dark brown to black cells of textura angularis, Munk pores present; inner layer composed of membranaceous, hyaline cells of textura prismatica. Asci (75-)80-95(-125) $\times(7-) 8-10(-13) \mu \mathrm{m}(\bar{x}=90 \times 9 \mu \mathrm{m}, \mathrm{n}=20), 8$ spored, unitunicate, subclavate to cylindrical, with a long pedicel, evanescent. Ascospores (8-)10$12(-14) \times 3-4.5(-6) \mu \mathrm{m}(\bar{x}=11 \times 4 \mu \mathrm{m}, \mathrm{n}=50)$, hyaline to brown, oval to ellipsoidal, 1 -septate, smooth-walled, with an apical germ pore, guttulate. Asexual morph: Undetermined (adapted from Patouillard \& Lagerheim 1895).

Material examined - Puerto Rico, El Yunque National Forest, El Verde Research Area, 16-ha Grid, Luquillo Mts, 350 to 425 m, on decorticated wood, 26 January 1996, S.M. Huhndorf (FSMH2070).

Known hosts and distribution - on decayed wood in Ecuador (type locality), Puerto Rico and Kenya (Patouillard \& Lagerheim 1895, Mugambi \& Huhndorf 2010).

Notes - The strains of Gaillardiella pezizoides were sequenced by Mugambi \& Huhndorf (2010). In this study, these strains are sister to Bertia sinensis (57\%ML/1.00BY, Fig. 1). We were unable to obtain the type material of $G$. pezizoides and therefore, re-examined and illustrated an authentic specimen SMH2070 collected by Huhndorf.

Ceratostomataceae G. Winter [as 'Ceratostomeae'], Rabenh. Krypt. -Fl., Edn 2 (Leipzig) 1.2: 247 (1885)

Saprobic on wood or vegetation or dung or parasitic on other fungi or closely associated with other fungi or isolated from soil. Sexual morph: Ascomata perithecial or without an external opening, solitary or gregarious, superficial to semi-immersed, carbonaceous, coriaceous or membranaceous, opaque or translucent, yellow to brown, usually glabrous, globose to subglobose, with or lacking ostioles, usually with long necks. Necks cylindrical to conical or absent, comprising fasciculate, pale yellow to brown, cylindrical, septate hyphae, straight or slightly curved, with a tapering or jagged apex, sometimes swelling near the apex, ascospores usually accumulating in necks. Peridium membranaceous, composed of yellow to brown cells of textura angularis or textura prismatica. Asci 4-8-spored, or multi-spored, unitunicate, cylindrical to clavate, pedicellate or sessile, apical ring absent, evanescent. Ascospores uni-, bi-seriate or irregularly arranged, hyaline to dark brown, ellipsoidal to broadly fusiform, aseptate, with a germ pore at one or each end, smooth or ornamented, mostly with guttules, without sheath. Asexual morph: Hyphomycetous. Conidiophores semi-macronematous, mononematous, hyaline to brown, branched or unbranched, phialidic or bulbils, sometimes swollen. Conidia aggregated, hyaline to brown, usually aseptate, globose to citriform or ellipsoidal, with guttules (adapted from Zukal 1885, Patouillard \& 
Lagerheim 1895, Whaley \& Barnett 1963, Jeng \& Cain 1977, Hoch 1977, Walker \& Minter 1981, Cannon 1982, Cannon \& Hawksworth 1982, Horie et al. 1986, Vakili 1989, Matsushima 1995, García et al. 2004, Mugambi \& Huhndorf 2010, Fan et al. 2012, Maharachchikumbura et al. 2015, Chaudhary et al. 2016, Marin-Felix et al. 2018, Crous et al. 2019b, Hyde et al. 2020e).

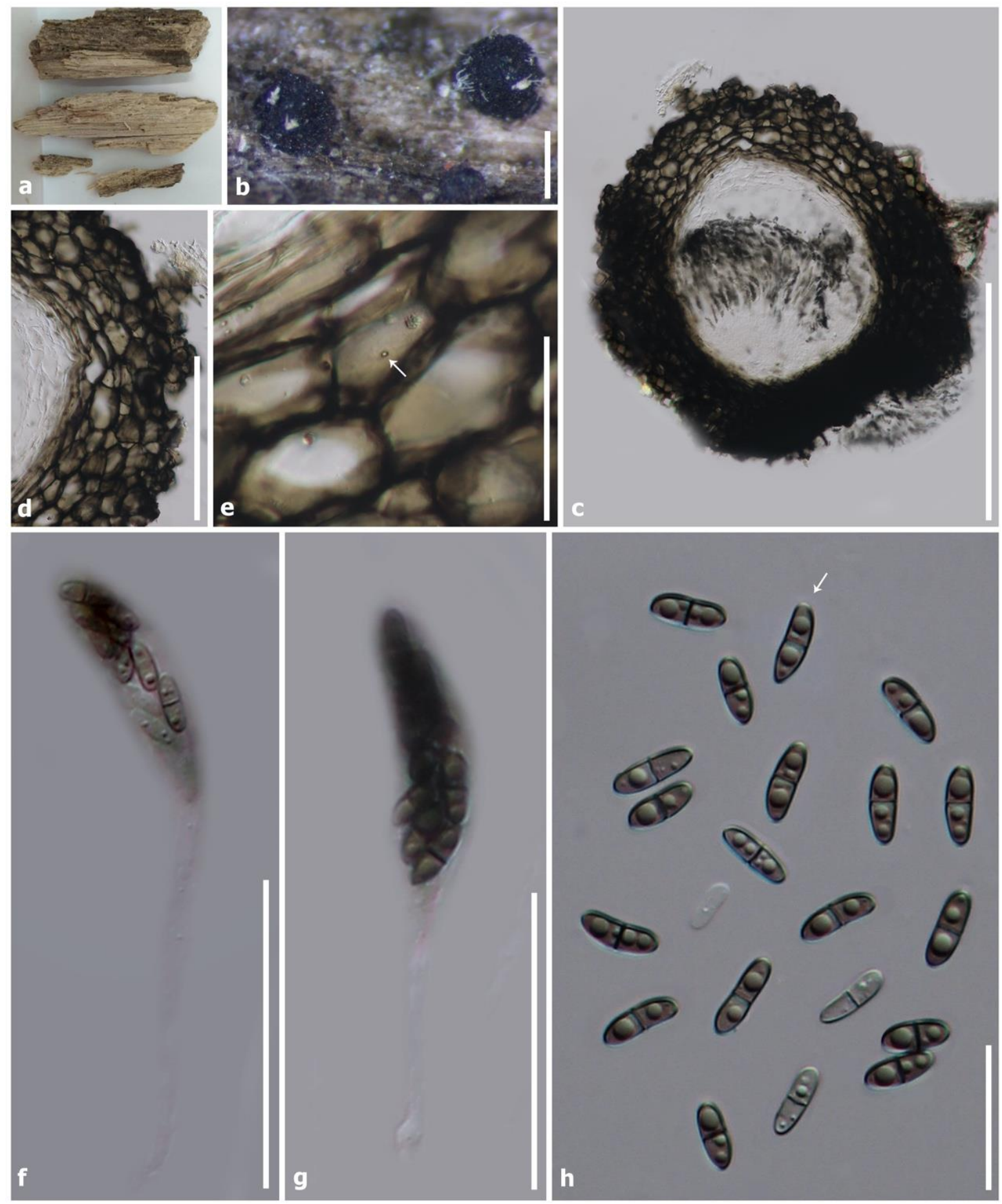

Figure 3 - Gaillardiella pezizoides: (F-SMH2070). a Material. b Ascoma on wood. c Ascoma cross section. d-e Peridium (arrow points to Munk pores). $\mathrm{f}-\mathrm{g}$ Asci. $\mathrm{h}$ Ascospores (arrow points to germ pore). Scale bars: $\mathrm{b}-\mathrm{c}=500 \mu \mathrm{m}, \mathrm{d}=200 \mu \mathrm{m}, \mathrm{e}-\mathrm{g}=50 \mu \mathrm{m}, \mathrm{h}=20 \mu \mathrm{m}$.

\section{Melanospora Corda}

Notes - The family Ceratostomataceae was introduced by Winter (1885) and is characterized by opaque to semi-translucent, yellow to brown ascomata with cylindrical to clavate asci and 
brown to dark brown, aseptate ascospores without a sheath (Hyde et al. 2020e). Ceratostomataceae was considered as a synonym of Melanosporaceae based on the similar morphology of the hyphomycetous asexual morph (Cannon \& Hawksworth 1983, Horie et al. 1986, Barr 1990, Hawksworth et al. 1995, Gams 2000). Subsequently, this family was accommodated in Coronophorales (= Melanosporales) based on phylogenetic study (Zhang \& Blackwell 2002, Zhang et al. 2006, Hibbett et al. 2007, Maharachchikumbura et al. 2015, 2016, Hongsanan et al. 2017, Hyde et al. 2017, 2020e, Wijayawardene et al. 2020). Wijayawardene et al. (2020) listed 14 genera in this family, viz Arxiomyces, Dactylidispora, Echinusitheca, Erythrocarpon, Harzia, Melanospora, Microthecium, Pseudomicrothecium, Pustulipora, Rhytidospora, Scopinella, Setiferotheca, Syspastospora and Vittatispora. In this study, phylogenetically, Gonatobotrys is sister to Vittatispora and Neotrotteria is basal to other Ceratostomataceae; and these two genera are accepted as additional members of Ceratostomataceae (Fig. 1). Therefore, 16 genera are accepted in Ceratostomataceae based on morphology and/or phylogenetic results.

Arxiomyces P.F. Cannon \& D. Hawksw., Trans. Br. mycol. Soc. 81(3): 644 (1983)

Saprobic on wood and/or isolated from soil. Sexual morph: Ascomata perithecial, gregarious, semi-immersed or erumpent through attached bark, globose to subglobose, dark brown to black, sometimes semi-translucent, glabrous or slightly hairy, ostiolate, with long necks. Asci 4- or 8spored, unitunicate, obovoid to clavate, with long tapering pedicel, apical ring indistinct or absent, evanescent. Ascospores irregular or bi-seriate, hyaline becoming brown or dark brown, ovoid to ellipsoidal, aseptate, smooth-walled, mostly with guttules, with a rounded apex and truncated base, usually with a collapsed germ pore. Asexual morph: Undetermined (adapted from Cannon \& Hawksworth 1983, Horie et al. 1986).

Notes - Arxiomyces accommodates three species, A. campanulatus, A. vitis and A. zuberiensis, and is characterized by ellipsoidal ascospores with a rounded apex and truncated base, but no molecular data is available for this genus (Cannon \& Hawksworth 1982, 1983, Horie et al. 1986). These characteristics are similar to Melanospora; thus, Arxiomyces was placed in Ceratostomataceae (Cannon \& Hawksworth 1982, 1983, Horie et al. 1986, Maharachchikumbura et al. 2016, Hyde et al. 2020e).

Arxiomyces vitis (Fuckel) P.F. Cannon \& D. Hawksw., Trans. Br. mycol. Soc. 81(3): 644 (1983)

Basionym - Ceratostoma vitis Fuckel, Jb. nassau. Ver. Naturk. 23-24: 129 (1870)

Fig. 4

Facesoffungi number: FoF 10054

Saprobic on wood. Sexual morph: Ascomata 150-200 $\mu \mathrm{m}(\bar{x}=170 \mu \mathrm{m}, \mathrm{n}=10)$ diam. at venter, perithecial, gregarious, semi-immersed or erumpent through attached bark, globose to subglobose, dark brown to black, glabrous or slightly hairy 3.5-5.5 $\mu \mathrm{m}$ wide, ostiolate, with long, cylindrical necks 500-1500 × 40-70 $\mu \mathrm{m}$, often curved. Peridium 25-50 $\mu \mathrm{m}$, membranaceous, comprising two layers, outer layer composed of dark brown to brown cells of textura angularis; inner layer composed of hyaline cells of textura angularis. Asci $14-17(-19) \times 11-15 \mu \mathrm{m}(\bar{x}=16 \times$ $13 \mu \mathrm{m}, \mathrm{n}=30$ ) ascospore-bearing part, 4- or 8-spored, unitunicate, obovoid to clavate, with long tapering pedicel, apical ring indistinct or absent, quickly evanescent. Ascospores $6-9 \times 4.5-7 \mu \mathrm{m}(\bar{x}$ $=7.5 \times 5.5 \mu \mathrm{m}, \mathrm{n}=50$ ), irregular or bi-seriate, aseptate, hyaline, ovoid to ellipsoidal, becoming brown or dark brown, with rounded apex and truncated base with an obvious collapsed germ pore, collapsing as a small, central, conical protuberance, smooth-walled, mostly with guttules. Asexual morph: Undetermined.

Material examined - Germany, Hessen, Oestrich-Winkel ( $9^{\circ} 00^{\prime} 19^{\prime}$ ' E / 49 46’ 28” N), on decaying radices of Vitis vinifera, in winter, K.W.G. Fuckel (G-G00266143, holotype); Germany, Saxony, at the churchyard of the Königstein fortress, on rotting roots of Humulus lupulus, 2 April 1886, K.W. Krieger (NY-03380967).

Known hosts and distribution - on decayed wood in Germany (type locality) (Fuckel 1870b).

Notes - We re-examined the type specimen, G00266143, and provided an illustration. 

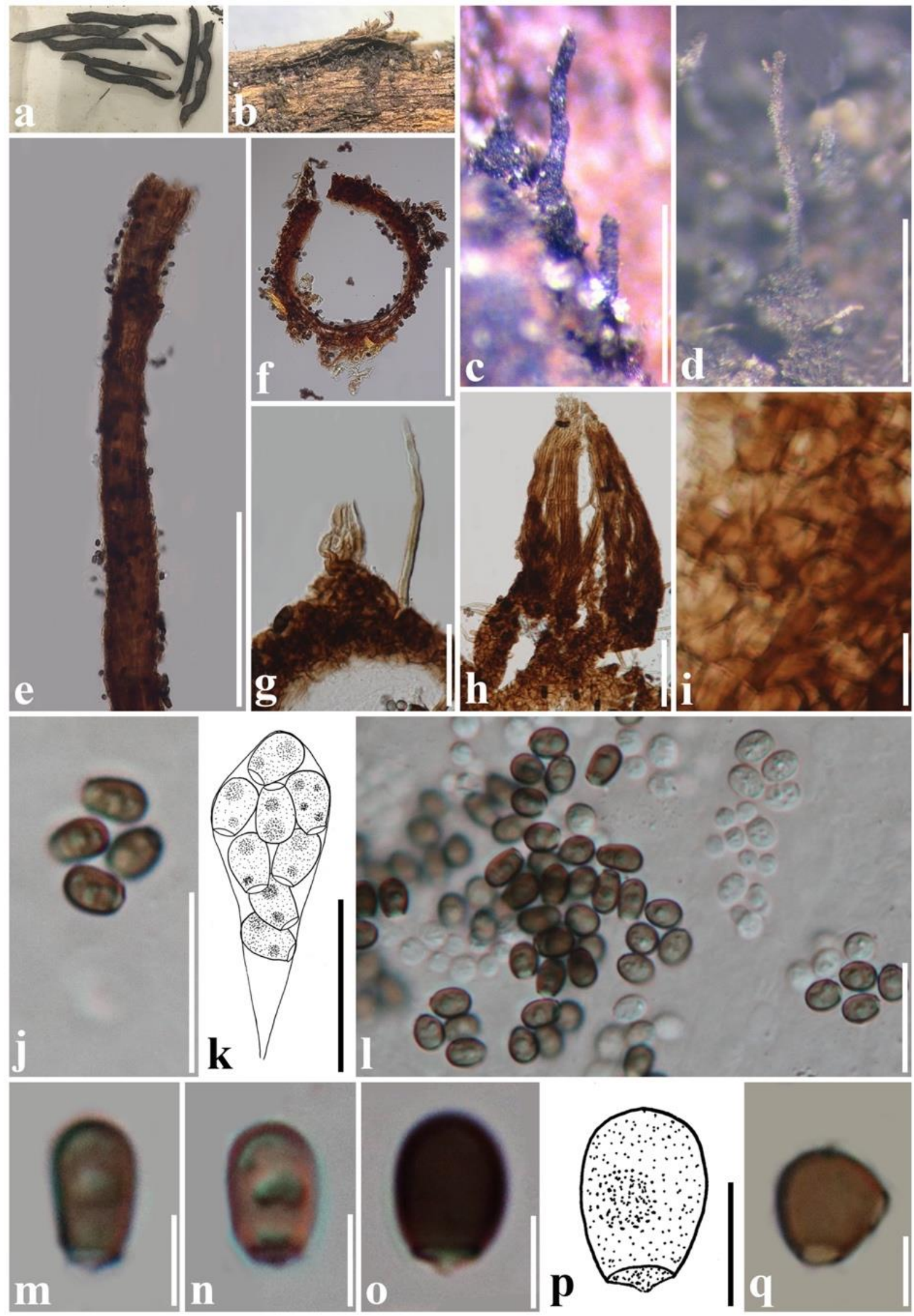

Figure 4 - Arxiomyces vitis: a, c, g-j, 1-o, q (G-G00266143, holotype), k, p (Drawn following observation by microscope); b, d-f (NY-03380967). a Material. b Gregarious ascomata on the host. c Semi-immersed ascomata. d Ascoma with long neck. e Squashed neck. f Venter of ascoma cross section. g Hairs at base. $h$ Neck with fasciculate cells. i Irregular cells at venter of ascoma. $\mathrm{j}-\mathrm{k}$ Asci. $1-\mathrm{q}$ Ascospores (q stained in Melzer's reagent). Scale bars: $\mathrm{c}-\mathrm{d}=500 \mu \mathrm{m}, \mathrm{e}-\mathrm{f}=200 \mu \mathrm{m}$, $\mathrm{h}=100 \mu \mathrm{m}, \mathrm{g}=50 \mu \mathrm{m}, \mathrm{i}-\mathrm{l}=20 \mu \mathrm{m}, \mathrm{m}-\mathrm{q}=5 \mu \mathrm{m}$. 
Dactylidispora Y. Marín, Stchigel, Guarro \& Cano, in Marin-Felix et al., MycoKeys 44: 89 (2018)

Isolated from soil. Sexual morph: Ascomata perithecial or without an external opening, superficial, globose to pyriform, yellow to brown, membranaceous, glabrous or setose, with or lacking ostioles. Necks conical, with crown of setae surrounding the ostioles. Peridium composed of yellow to pale brown cells of textura angularis, membranaceous. Asci 8-spored, unitunicate, broadly clavate, evanescent. Ascospores irregular or bi-seriate, aseptate, hyaline becoming brown to dark brown, broadly fusiform to citriform, umbonate and truncate at both ends, smooth-walled, germ pore with a raised rim at each end, mostly with guttules. Asexual morph: Conidia hyaline, subglobose to ovoid, smooth-walled (adapted from Marin-Felix et al. 2018).

Notes - Dactylidispora was introduced based on Sphaerodes ellipsospora and $S$. singaporensis and, those two are sister to Melanospora kurssanoviana based on phylogenetic results (Marin-Felix et al. 2018). This genus is characterized by citriform ascospores with a germ pore surrounded by a raised rim at each end (Marin-Felix et al. 2018). These features are similar to Pustulipora and Vittatispora; although Pustulipora has ascomata without neck and 4-spored asci (Cannon 1982), and Vittatispora has a hyaline ridge between the germ pores on ascospores (Chaudhary et al. 2006). In this study, Dactylidispora species clustered in Ceratostomataceae (80\% ML/1.00BY, Fig. 1).

Dactylidispora ellipsospora (Takada) Y. Marín, Stchigel, Guarro \& Cano, in Marin-Felix et al., MycoKeys 44: 90 (2018)

Basionym - Microthecium ellipsosporum Takada, in Kobayasi et al., Bull. natn. Sci. Mus., Tokyo 16(3): 527 (1973)

Facesoffungi number: FoF 10145

Isolated from soil. Sexual morph: Ascomata superficial, globose, without an external opening, yellow to brown, membranaceous. Peridium composed of yellow to pale brown cells of textura angularis. Asci 8-spored, unitunicate, broadly clavate, evanescent. Ascospores irregular or biseriate, aseptate, hyaline becoming brown to dark brown, broadly fusiform to citriform, umbonate and truncate at both ends, smooth-walled, germ pore with a raised rim at each end, mostly with guttules. Asexual morph: Undetermined (adapted from García et al. 2004, Marin-Felix et al. 2018).

Known hosts and distribution - on forest soil in Papua New Guinea (type locality) (Takada 1973).

Notes - Dactylidispora ellipsospora was initially named Microthecium ellipsosporum (Takada 1973). Marin-Felix et al. (2018) sequenced its ex-type strain, NBRC 31376, and established this species as the generic type of Dactylidispora. In this study, D. ellipsospora is sister to D. singaporennsis (95\% ML/1.00BY) in Ceratostomataceae (Fig. 1).

Echinusitheca Y. Marín, Stchigel, Dania García, Guarro, A.N. Mill. \& Cano, in Marin-Felix et al., MycoKeys 44: 91 (2018)

Isolated from soil. Sexual morph: Ascomata superficial or immersed, globose, without an external opening, pale brown to brown, semi-translucent, membranaceous, surrounded by setae. Setae straight, pale brown to brown, 0-1-septate, verrucose to tuberculate, tapering, sometimes branched. Peridium composed of brown to hyaline cells of textura angularis to textura globulosa. Asci 8-spored, unitunicate, globose to subglobose, sessile. Ascospores irregular, aseptate, hyaline becoming brown to dark brown, ellipsoidal, smooth-walled, with a germ pore at each end, mostly with guttules. Asexual morph: Undetermined (adapted from Marin-Felix et al. 2018).

Notes - Marin-Felix et al. (2018) established the monotypic Echinusitheca typified by E. citrispora. It is similar to Melanospora in having translucent ascomata and ellipsoidal ascospores; however, the former has globose ascomata and globose to subglobose asci, whereas the latter has ascomata with long necks and clavate asci (Zhang \& Blackwell 2002, Marin-Felix et al. 2018). It nests in Ceratostomataceae based on multi-gene phylogeny (Marin-Felix et al. 2018, this study, Fig. 1). 
Echinusitheca citrispora Y. Marín, Stchigel, Dania García, Guarro, A.N. Mill. \& Cano, in MarinFelix et al., MycoKeys 44: 92 (2018)

Facesoffungi number: FoF 10146

Isolated from soil. Sexual morph: Ascomata superficial or immersed, globose, without an external opening, pale brown to brown, semi-translucent, membranaceous, surrounded by setae. Setae straight, pale brown to brown, 0-1-septate, verrucose to tuberculate, tapering, sometimes branched. Peridium composed of brown to hyaline cells of textura angularis to textura globulosa. Asci 8-spored, unitunicate, globose to subglobose, sessile. Ascospores irregular, aseptate, hyaline becoming brown to dark brown, ellipsoidal, smooth-walled, with a germ pore at each end, mostly with guttules. Asexual morph: Undetermined (adapted from Marin-Felix et al. 2018).

Known hosts and distribution - on forest soil in the USA (type locality) (Marin-Felix et al. 2018).

Notes - Marin-Felix et al. (2018) proposed that Echinusitheca citrispora is similar to Arxiomyces and Scopinella species in having dark semi-translucent ascomata. However, E. citrispora has smooth-walled, ellipsoidal ascospores, while Arxiomyces has ascospores with a rounded apex and truncated base, and Scopinella has ascospores with two prominent longitudinal germ slits (Marin-Felix et al. 2018). The type strain Echinusitheca citrispora (CBS 137837) nests in Ceratostomataceae in the phylogenetic results (Marin-Felix et al. 2018, this study, Fig. 1).

\section{Erythrocarpon Zukal, Verh. zool.-bot. Ges. Wien 35: 337 (1886)}

Saprobic on wood. Sexual morph: Ascomata perithecial, solitary, superficial, globose, reddish brown, membranaceous, surrounded by septate, filiform hyphae, ostiolate. Peridium composed of brown to hyaline cells of textura angularis. Asci 8-spored, unitunicate, cylindrical. Ascospores uniseriate, hyaline to reddish brown, broadly fusiform to ellipsoidal, with germ pore at each end, aseptate, smooth-walled, with guttules. Asexual morph (associated): Hyphomycetous. Conidiophores mononematous, erect, hyaline to brown, septate, branched. Conidia hyaline to brown, fusiform and 0-4-septate, or globose to subglobose and aseptate, or stellated, verrucose (adapted from Zukal 1885).

Notes - The monotypic Erythrocarpon was introduced by Zukal (1885) and is characterized by reddish brown, hairy and globose ascomata with broadly fusiform, reddish brown ascospores with germ pore at each end (Zukal 1885). It has two types of accompanied asexual morph on natural substrate, one has fusiform, septate conidia, and the other has globose or stellate, verrucose conidia (Zukal 1885).

\section{Type species - Erythrocarpon microstomum Zukal, Verh. zool.-bot. Ges. Wien 35: 337 (1886)}

Facesoffungi number: FoF 10147

Fig. $8 \mathrm{~g}-\mathrm{k}$

Saprobic on wood. Sexual morph: Ascomata perithecial, solitary, superficial, globose, reddish brown, membranaceous, surrounded by septate, filiform hyphae, ostiolate. Peridium composed of hyaline to brown cells of textura angularis. Asci 8-spored, unitunicate, cylindrical. Ascospores uniseriate, hyaline to reddish brown, broadly fusiform to ellipsoidal, with germ pore at each end, aseptate, smooth-walled, with guttules. Asexual morph: Hyphomycetous. Conidiophores mononematous, erect, hyaline to brown, septate, branched. Conidia hyaline to brown, fusiform and 0-4-septate or globose to star-shaped and aseptate, verrucose (adapted from Zukal 1885).

Known hosts and distribution - on decayed wood in Austria (type locality) (Zukal 1885).

Notes - Erythrocarpon microstomum is similar to Melanospora zamiae in having ellipsoidal to broadly fusiform ascospores, but the latter has translucent ascomata with a long neck; therefore, it was considered as a member of Ceratostomataceae (Zukal 1885, Maharachchikumbura et al. 2016, Hyde et al. 2020e). There is no molecular data available for this species.

Gonatobotrys Corda, Pracht-Fl. Eur. Schimmelbild.: 9 (1839)

Saprobic on wood or vegetation. Sexual morph: Undetermined. Asexual morph: 
Hyphomycetous. Mycelium composed of hyaline to light brown, superficial, effused, smoothwalled, branched, septate hyphae. Conidiophores mononematous, macronematous, hyaline, erect, septate, branched or unbranched, smooth-walled. Conidiogenous cells terminal to intercalary, polyblastic, globose to subglobose, hyaline to pale brown, swollen. Conidia solitary, obovoid to ellipsoidal, with a raised rim at base, 0 -multi-septate, holoblastic, hyaline to pale brown, smooth to verrucose, conidial secession with conspicuous denticles on the conidia and conidiogenous cells (adapted from Hoch 1977, Walker \& Minter 1981, Whaley \& Barnett 1963).

Notes - Gonatobotrys was introduced by Corda (1839), and is well known as fungicolous hyphomycetes of Alternaria and Fusarium species (Hoch 1977, Walker \& Minter 1981, Whaley \& Barnett 1963). The type species Gonatobotrys simplex was considered as the asexual morph of Melanospora damnosa, and was synonymised as M. simplex (Vakili 1989, Réblová et al. 2016). However, Crous et al. (2020b) proposed that characters of hyphomycetous Gonatobotrys were never observed in Melanospora cultures. Melanospora damnosa is distinct from G. simplex based on phylogenetic results (Vu et al. 2019, Crous et al. 2020b). In this study, Gonatobotrys is sister to Vittatispora (56\%ML/0.97BY) in Ceratostomataceae, but distinct from Melanospora clade based on multi-gene phylogeny (Fig. 1). Therefore, we accept Gonatobotrys as a genus in Ceratostomataceae.

Gonatobotrys simplex Corda, Prachtflora: 9 (1839)

Fig. 5

Facesoffungi number: FoF 10055

Saprobic on rotting vegetation. Sexual morph: Undetermined. Asexual morph: Hyphomycetous. Mycelium composed of hyaline to light brown, superficial, effused, smoothwalled, branched, septate hyphae $2-4 \mu \mathrm{m}(\bar{x}=3, \mathrm{n}=10)$ wide. Conidiophores $5-8 \mu \mathrm{m}(\bar{x}=6.5, \mathrm{n}=$ 30) wide, mononematous, macronematous, hyaline, erect, septate, unbranched, smooth-walled. Conidiogenous cells $9-14 \mu \mathrm{m}(\bar{x}=10.5 \mu \mathrm{m}, \mathrm{n}=20)$ diam., terminal to intercalary, polyblastic, globose to subglobose, hyaline to pale brown, swollen. Conidia $(12-) 14-18(-22) \times 8-12 \mu \mathrm{m}(\bar{x}=$ $16 \times 10 \mu \mathrm{m}, \mathrm{n}=50$ ), solitary, obovoid to ellipsoidal, with a raised rim at base, aseptate, holoblastic, hyaline to pale brown, smooth to verrucose, conidial secession with conspicuous denticles on the conidia and conidiogenous cells (adapted from Vakili 1989).

Material examined - New Zealand, Auckland, on dry rootstock of Camelia sp., 27 April 1977, L.T.W. Mattson (PDD 47724).

Known hosts and distribution - on branches of Crataegus oxyacantha (Rosaceae) in Germany (type locality) (Corda 1839); on dead wood or vegetation in New Zealand, South Africa and USA (Vakili 1989, Crous et al. 2020b).

Notes - Gonatobotrys simplex was first collected on wood in Germany (Corda 1839) and Melanospora damnosa was found on culm of wheat in Italy (Saccardo \& Berlese 1896). Vakili (1989) linked these two species based on the fact that both fungi were found on their corn-meal agar. Thus, Réblová et al. (2016) reduced Gonatobotrys to a synonym of Melanospora. Subsequently, these species were sequenced by $\mathrm{Vu}$ et al. (2019) and Crous et al. (2020b) respectively. In this study, G. simplex and Vittatispora coorgii formed a clade (56\% ML/0.97BY) far from the Melanospora clade (Crous et al. 2020b, this study, Fig. 1). We could not obtain the type specimen; therefore, we re-examined the material that has similar characteristics with the description of G. simplex in Crous et al. (2020b).

Harzia Costantin, Mucéd. Simpl. (Paris): 42 (1888)

Saprobic on wood or leaves or isolated from soil. Sexual morph: Undetermined. Asexual morph: Hyphomycetous. Mycelium composed of hyaline, smooth-walled, branched, septate hyphae. Conidiophores mononematous, macronematous, hyaline, subcylindrical to cylindrical, erect, 0 multi-septate, tapering, smooth-walled. Conidia terminal to intercalary, solitary, obovoid to ellipsoidal, sometimes with a raised rim at base, aseptate, holoblastic, hyaline to brown, smooth to verrucose (adapted from Saccardo 1886, Costantin 1888, Poursafar et al. 2017, Crous et al. 2019b).

Notes - The hyphomycetous Harzia was considered to be related to members of Hypocreales 
(Maharachchikumbura et al. 2016, Wijayawardene et al. 2018), until Schultes et al. (2017) clarified the species in this genus based on molecular information and accepted Harzia as a member in Ceratostomataceae. In this study, Harzia species are sister to Melanospora (100\%ML/1.00BY) in Ceratostomataceae, except for Harzia velata which nests in Nectriaceae (Hypocreales) (100\%ML/1.00BY, Fig. 1).
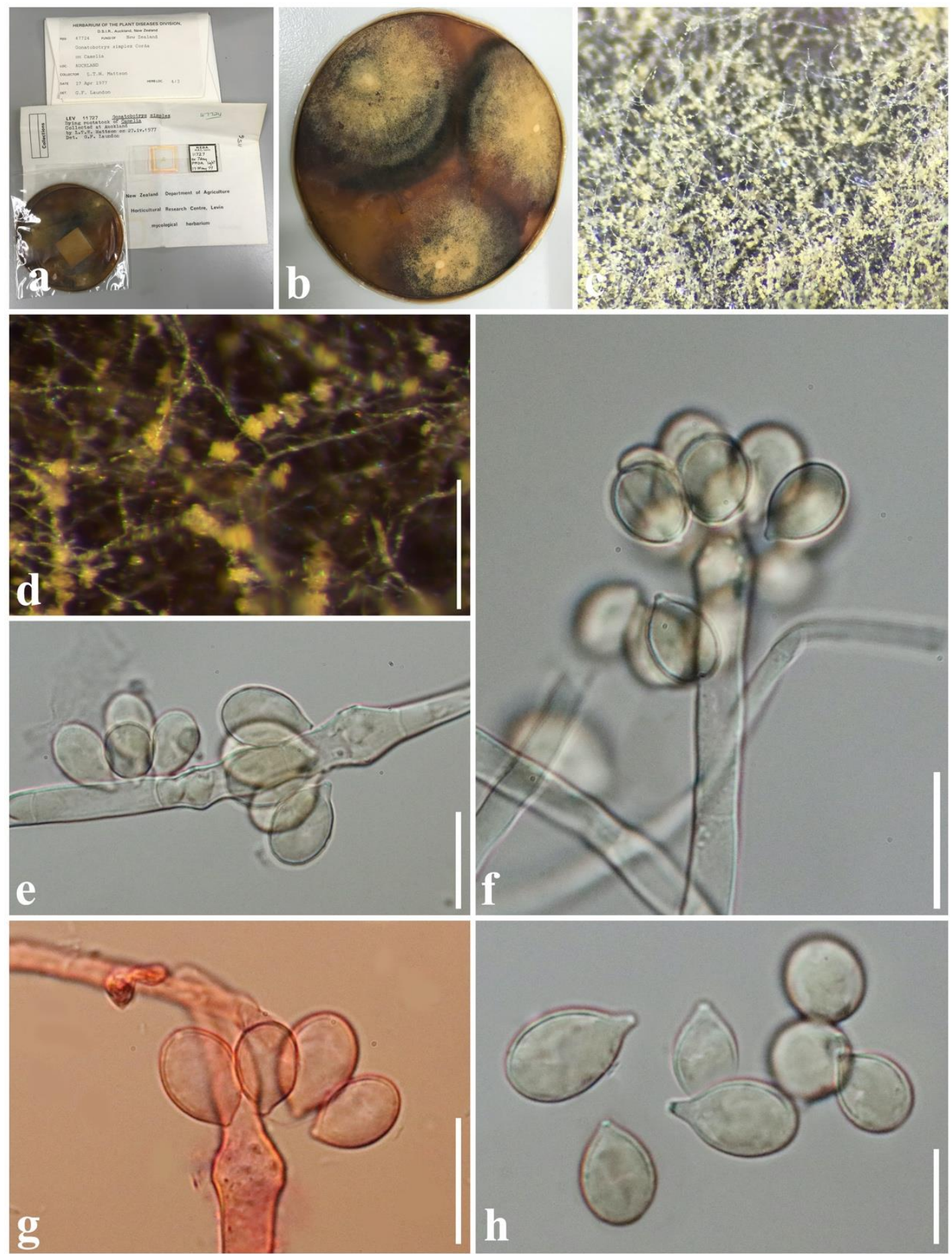

Figure 5 - Gonatobotrys simplex: (PDD-47724). a Material label. b Dry culture. c Mycelium. $\mathrm{d}$ Branched hyphae. $\mathrm{e}-\mathrm{g}$ Conidiophore with conidia ( $\mathrm{g}$ is strained in Congo red reagent). $\mathrm{h}$ Conidia. Scale bars: $\mathrm{d}=200 \mu \mathrm{m}, \mathrm{e}-\mathrm{g}=20 \mu \mathrm{m}, \mathrm{h}=10 \mu \mathrm{m}$.

Harzia acremonioides (Harz) Costantin, Mucéd. Simpl. (Paris): 42 (1888)

Basionym - Monosporium acremonioides Harz, Linig. Hyph.: 17 (1872) 
Facesoffungi number: FoF 10148

Saprobic on wood or leaves. Sexual morph: Undetermined. Asexual morph: Hyphomycetous. Mycelium composed of hyaline, smooth-walled, branched, septate hyphae. Conidiophores mononematous, macronematous, hyaline, subcylindrical to cylindrical, straight or slightly curved, erect, 1-2-septate, tapering, smooth-walled. Conidia terminal, solitary, obovoid to ellipsoidal, aseptate, holoblastic, hyaline to brown, smooth to verrucose (adapted from Saccardo 1886, Poursafar et al. 2017).

Known hosts and distribution - on diseased branches and leaves in Austria and Germany (type locality) (Saccardo 1886); on dune sand in France (Schultes et al. 2017); on diseased wheat and barley in Iran (Poursafar et al. 2017).

Notes - The generic type, Harzia acremonioides, was initially collected on diseased branches and leaves in Austria and Germany (Saccardo 1886). Schultes et al. (2017) sequenced the epitype strain of Monosporium acremonioides ( $\equiv H$. acremonioides) and defined this species in Ceratostomataceae. In our study, $H$. acremonioides is sister to $H$. verrucosa $(84 \% \mathrm{ML} / 0.97 \mathrm{BY}$, Fig. 1).

Melanospora Corda, Icon. fung. (Prague) 1: 24 (1837)

Saprobic on vegetation or dung or wood or parasitic on other fungi or closely associated with other fungi. Sexual morph: Ascomata perithecial, solitary, superficial to immersed, globose venter, usually with long necks, yellow to reddish brown, membranaceous, translucent or semi-translucent, glabrous, tomentose or hairy, ostiolate. Necks cylindrical to conical or absent, composed of fasciculate, cylindrical, pale yellow, septate hyphae, straight or slightly curved, with a jagged apex, ascospores usually accumulating in translucent necks. Peridium membranaceous, composed of yellow to pale brown cells of textura angularis. Asci 4- or 8-spored, unitunicate, obovoid to broadly clavate, evanescent. Ascospores irregular or bi-seriate, hyaline becoming brown or reddish brown, broadly fusiform, ellipsoidal to citriform, umbonate and truncate at both ends, aseptate, smoothwalled, verrucose or with reticulate ribs on surface, usually laterally collapsing, with a germ pore at each end, mostly with guttules. Asexual morph (associated): Hyphomycetous. Mycelium consisting of hyaline to pale brown, branched, septate, smooth-walled hyphae. Conidiophores hyaline, cylindrical, straight, curved or flexuous, septate, branched or unbranched. Conidia hyaline to brown, globose to ovoid, 0-1-septate (adapted from Rehner \& Samuels 1995, Seifert et al. 2011, Schultes et al. 2017, Marin-Felix et al. 2018).

Notes - Melanospora was introduced by Corda (1837) and its asexual morph was considered as Gonatobotrys and Harzia (Vakili 1989, Seifert et al. 2011, Schultes et al. 2017). However, Crous et al. (2020b) suggested that these asexual morphs have never been found on the culture of Melanospora. In this study, Melanospora is sister to Harzia (100\%ML/1.00BY), and distinct from Gonatobotrys based on phylogenetic result (Fig. 1). Therefore, these hyphomycetes are regarded as associated genera of Melanospora, until the cultural characteristics of Melanospora or molecular information is available to determine their relationships.

Melanospora zamiae Corda, Icon. fung. (Prague) 1: 24 (1837)

Fig. 6

Facesoffungi number: FoF 10056

Saprobic on rotting vegetation or dung. Sexual morph: Ascomata 95-240 $\mu \mathrm{m}(\bar{x}=180 \mu \mathrm{m}, \mathrm{n}$ = 10) diam., perithecial, solitary, superficial, globose venter with a long neck, yellow to reddish brown, membranaceous, semi-translucent, glabrous or slightly hairy, ostiolate. Necks 200-300 × 35-50 $\mu \mathrm{m}(\bar{x}=245 \times 42 \mu \mathrm{m}, \mathrm{n}=10)$, cylindrical, composed of fasciculate, cylindrical, pale yellow, septate hyphae $2-3 \mu \mathrm{m}$ wide, straight or slightly curved, with a jagged apex, ascospores usually accumulating in translucent necks. Peridium composed of yellow to pale brown cells of textura angularis to textura globulosa, membranaceous. Asci 4- or 8-spored, unitunicate, obovoid to broadly clavate, evanescent. Ascospores 20-23 $\times(12-) 14-15(-17) \mu \mathrm{m}(\bar{x}=22 \times 14.5 \mu \mathrm{m}, \mathrm{n}=50)$, irregular or bi-seriate, hyaline becoming brown or reddish brown, broadly fusiform to ellipsoidal, 
aseptate, smooth-walled, usually laterally collapsing, umbonate and truncate at each end, with germ pore at both ends, mostly with guttules. Asexual morph: Undetermined.
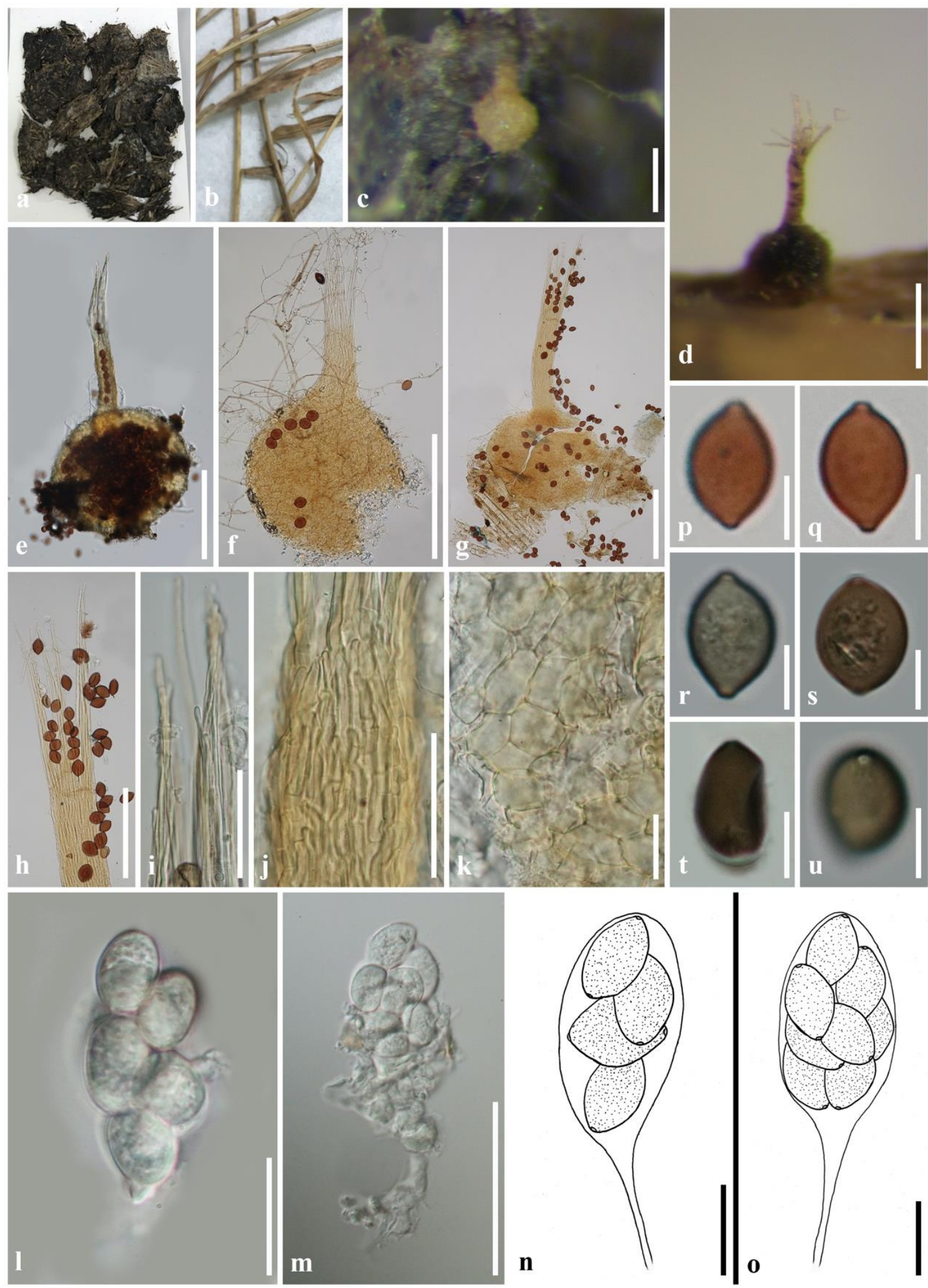

Figure 6 - Melanospora zamiae: a, g-h, p-q (UPS-UPS:BOT:F-129707); b, d-e, i-m, r-u (PDD 36919); c, f (UPS-UPS:BOT:F-129706); n-o (drawn from Cannon \& Hawksworth 1982). a-b Two types of host. c-d Superficial ascomata on the host. e-g Squashed ascomata with long neck. h Apex of neck with fasciculate hyphae. i Neck with a jagged apex. j Neck composed of cylindrical cells. $k$ Cells at venter of ascoma. $1-\mathrm{o}$ Asci. $\mathrm{p}-\mathrm{u}$ Ascospores ( $\mathrm{t}$ ascospore laterally collapsing). Scale bars: $\mathrm{d}-\mathrm{g}=200 \mu \mathrm{m}, \mathrm{c}, \mathrm{h}=100 \mu \mathrm{m}, \mathrm{i}-\mathrm{j}, \mathrm{m}=50 \mu \mathrm{m}, \mathrm{k}-\mathrm{l}, \mathrm{n}-\mathrm{O}=20 \mu \mathrm{m}, \mathrm{p}-\mathrm{u}=10 \mu \mathrm{m}$. 
Material examined - Sweden, Öland, Resmo par., $4 \mathrm{~km}$ E of the church on the Great Alvar, on cow dung in moist chamber in Uppsala, 2 June 1968, R. Santesson (UPS-UPS:BOT:F-129706); Sweden, Öland, Räpplinge, Borgholm, at the Castle ruin, on old horse dung in moist chamber, 30 August 1959, N. Lundqvist (UPS-UPS:BOT:F-129707); New Zealand, Auckland, on leaves of Microlaena stipoides, 14 April 1975, J.M. Dingley (PDD 36919).

Known hosts and distribution - on decayed leaves of Zamia pungens (Zamiaceae) in Germany (type locality) (Corda 1837); on dung or leaves in Israel, New Zealand and Sweden (Vu et al. 2019).

Notes - The generic type Melanospora zamiae has been considered as conspecific with $M$. damnosa (Cannon \& Hawksworth 1982, Réblová et al. 2016). However, these two species exist independently in Melanospora based on phylogenetic results (Marin-Felix et al. 2018, Vu et al. 2019). Figure 1 reveals that Melanospora species clustered as a distinct clade (100\% ML/1.00BY), except M. kurssanoviana which is basal to Harzia, Melanospora and Microthecium (57\% ML/1.00BY, Fig. 1). We were unable to obtain the type specimen, therefore, we re-examined authentic materials collected by Lundqvist (UPS:BOT:F-129707) or determined by Samuels (36919, mentioned in the label of material).

Microthecium Corda, Icon. fung. (Prague) 5: 30, 74 (1842)

Saprobic on wood or leaves or isolated from soil, sometimes fungicolous. Sexual morph: Ascomata perithecial or without an external opening, superficial or immersed, globose to subglobose, scattered or gregarious, yellowish to brown, membranaceous, translucent, glabrous, tomentose or hairy, necks short or absent, with or lacking ostioles. Peridium usually translucent or semi-translucent, membranaceous, composed of yellow to pale brown cells of textura angularis. Asci 4- or 8-spored, clavate to pyriform, evanescent. Ascospores irregular or bi-seriate, hyaline becoming brown to black, ellipsoidal to citriform, usually umbonate and truncate at both ends, smooth-walled or verrucose or with reticulate ribs on surface, with a germ pore at each end, mostly with guttules. Sexual morph: Conidiophores unbranched or branched, cylindrical, septate. Conidia subglobose to oval, hyaline to pale brown, smooth-walled. Bulbils globose to ellipsoidal, pale brown to reddish brown (adapted from Udagawa \& Cain 1969, Marin-Felix et al. 2018).

Notes - Microthecium was introduced by Corda (1842) and typified by $M$. zobelii which was found growing in the hymenial tissue of Rhizopogon albus. This genus has translucent ascomata and ellipsoidal to citriform ascospores with umbonate and truncated ends, simliar to Melanospora and Sphaerodes (Winter 1887b, Cannon \& Hawksworth 1982). Therefore, Microthecium was regarded as a synonym of Melanospora, until Marin-Felix et al. (2018) sequenced several species in these two genera, and Microthecium species existed in Ceratostomataceae as a clade independent of Melanospora. Thus, Microthecium was re-accepted as a genus in Ceratostomataceae (Hyde et al. 2020e, Wijayawardene et al. 2020). In this study, Microthecium species clustered (86\% ML/0.92BY) and are basal to Harzia and Melanospora (57\%ML/1.00BY) in Ceratostomataceae (Fig. 1).

Microthecium zobelii Corda, Icon. fung. (Prague) 5: 74 (1842)

Fig. 81

Facesoffungi number: FoF 10149

Saprobic on dung or isolated from soil, or fungicolous. Sexual morph: Ascomata superficial or immersed, globose to subglobose, without an external opening, scattered or gregarious, yellowish to brown, membranaceous, translucent, glabrous or hairy. Peridium membranaceous, composed of yellow to pale brown cells of textura angularis. Asci 8-spored, clavate, evanescent. Ascospores irregular or bi-seriate, hyaline becoming brown to black, ellipsoidal to citriform, usually umbonate and truncate at both ends, smooth-walled, with a germ pore at each end, mostly with guttules. Sexual morph: Conidia subglobose to oval, hyaline to pale brown, smooth-walled (adapted from Udagawa \& Cain 1969, Marin-Felix et al. 2018).

Known hosts and distribution - on Rhizopogon albus in Germany (type locality) (Corda 1842); on Choiromyces maeandriformis in Czech Republic (Udagawa \& Cain 1969); on decayed 
Coriolus flabelliformis in Papua New Guinea (Marin-Felix et al. 2018, Wang et al. 2019a); on roe dung in Netherlands (Wang et al. 2019a); on soil in Japan (Hawksworth \& Udagawa 1977).

Notes - Microthecium zobelii has ascomata without an external opening and ellipsoidal to citriform ascospores with a terminal apiculate or depressed germ pore at each end (Marin-Felix et al. 2018). In this study, M. zobelii (CBS 341.73) nests in Microthecium based on the phylogenetic result (Fig. 1).

Neotrotteria Sacc., Bulletino dell'orto Botanico della R. Universitá di Napoli 6: 45 (1921)

Saprobic on decorticated wood. Sexual morph: Subiculum extensive, forming large and dense patches, composed of densely clustered, abundant, brown to black, septate, branched, spinulose hyphae with dichotomously branched, tapering ends. Ascomata superficial, collabent, cupulate, turbinate, tuberculate, scattered, black, carbonaceous, lacking ostioles, surrounded by rigid, straight, tapering setae. Peridium centrum with an obconical Quellkörper, comprising three layers, outer layer composed of carbonaceous, black tissues; middle layer composed of membranaceous, olivaceous to brown cells of textura angularis, Munk pores present; inner layer composed of membranaceous, hyaline cells of textura prismatica. Asci multi-spored, unitunicate, cylindrical to clavate, evanescent. Ascospores irregularly arranged, hyaline, allantoid to oval, slightly curved, smooth-walled, aseptate, mostly with guttules. Asexual morph: Undetermined.

Notes - The monotypic Neotrotteria was introduced by Saccardo (1918) and typified by $N$. pulchella in having carbonaceous ascomata with an obconical Quellkörper and clavate asci with numerous spores. These characters were considered similar to Acanthonitschkea (Nitschkiaceae), thus, N. pulchella was transferred as A. pulchella (Nannfeldt 1975, Nannfeldt \& Santesson 1975). Subsequently, Mugambi \& Huhndorf (2010) analyzed LSU sequence data and found that this species is basal to other Scortechiniaceae species. In this study, Neotrotteria is morphologically similar to genera in Scortechiniaceae that have cupulate ascomata with Quellkörper, however, phylogenetically, this genus nests in Ceratostomataceae based on LSU sequence $(83 \% \mathrm{ML}$, not show) and multi-gene analyses (68\%ML, Fig. 1). Therefore, Neotrotteria has an existence between Ceratostomataceae and Scortechiniaceae. However, we place Neotrotteria in Ceratostomataceae based on our phylogenetic result (Fig. 1).

Neotrotteria pulchella Sacc., Bulletino dell'orto Botanico della R. Universitá di Napoli 6: 45 (1918)

Facesoffungi number: FoF 10057

Fig. 7

Saprobic on decorticated wood. Sexual morph: Subiculum extensive, forming large and dense patches, composed of densely clustered, abundant, brown to black, septate, branched, spinulose hyphae 4.5-7 $\mu \mathrm{m}$ thick, with dichotomously branched, tapering ends. Ascomata 300-400 $\times 325-$ $400 \mu \mathrm{m}(\bar{x}=340 \times 360 \mu \mathrm{m}, \mathrm{n}=5)$, superficial, collabent, cupulate, turbinate, tuberculate, scattered, black, carbonaceous, lacking ostioles, with rigid, straight, tapering setae 7-13 $\mu \mathrm{m}$ thick. Peridium centrum with an obconical Quellkörper 65-110 × 140-200 $\mu \mathrm{m}(\bar{x}=85 \times 160 \mu \mathrm{m}, \mathrm{n}=10)$, comprising three layers 45-70 $\mu \mathrm{m}$ thick, outer layer composed of carbonaceous, black tissues; middle layer composed of membranaceous, olivaceous to brown cells of textura angularis, Munk pores present; inner layer composed of membranaceous, hyaline cells of textura prismatica. Asci multi-spored, unitunicate, cylindrical to clavate, evanescent. Ascospores $3.5-5 \times 1-2 \mu \mathrm{m}(\bar{x}=4 \times$ $1.2 \mu \mathrm{m}, \mathrm{n}=50$ ), irregularly arranged, hyaline, allantoid to oval, slightly curved, smooth-walled, aseptate, mostly with guttules. Asexual morph: Undetermined.

Material examined - China, Taiwan, Kukuan, on stems of Lycium chinense, 17 July 1990, C.Y. Chen (IMI 354793).

Known hosts and distribution - on decayed wood of rubber tree (Hevea brasiliensis) in Singapore (type locality) (Saccardo 1918); on stems of Lycium chinense (Solanaceae) in China; on dead wood in Kenya (Mugambi \& Huhndorf 2010).

Notes - Neotrotteria pulchella is characterized by carbonaceous ascomata that have obconical Quellkörper and surrounded by tapering setae, multi-spored asci and oval to allantoid 
ascospores (Saccardo 1918). Subsequently, this species was considered as a member of Nitschkiaceae or Coronophoraceae (Nannfeldt 1975, Nannfeldt \& Santesson 1975, Subramanian \& Sekar 1990). Mugambi \& Huhndorf (2010) clarified the genera in Coronophorales and found that N. pulchella groups together with Scortechiniaceae based on LSU sequence analysis. In this study, N. pulchella nests in Ceratostomataceae based on phylogenetic result (68\% ML, Fig. 1). We were unable to obtain the type material. Therefore, we re-examined an authentic specimen, 354793, which was determined by Sivanesan (mentioned in the label of material).

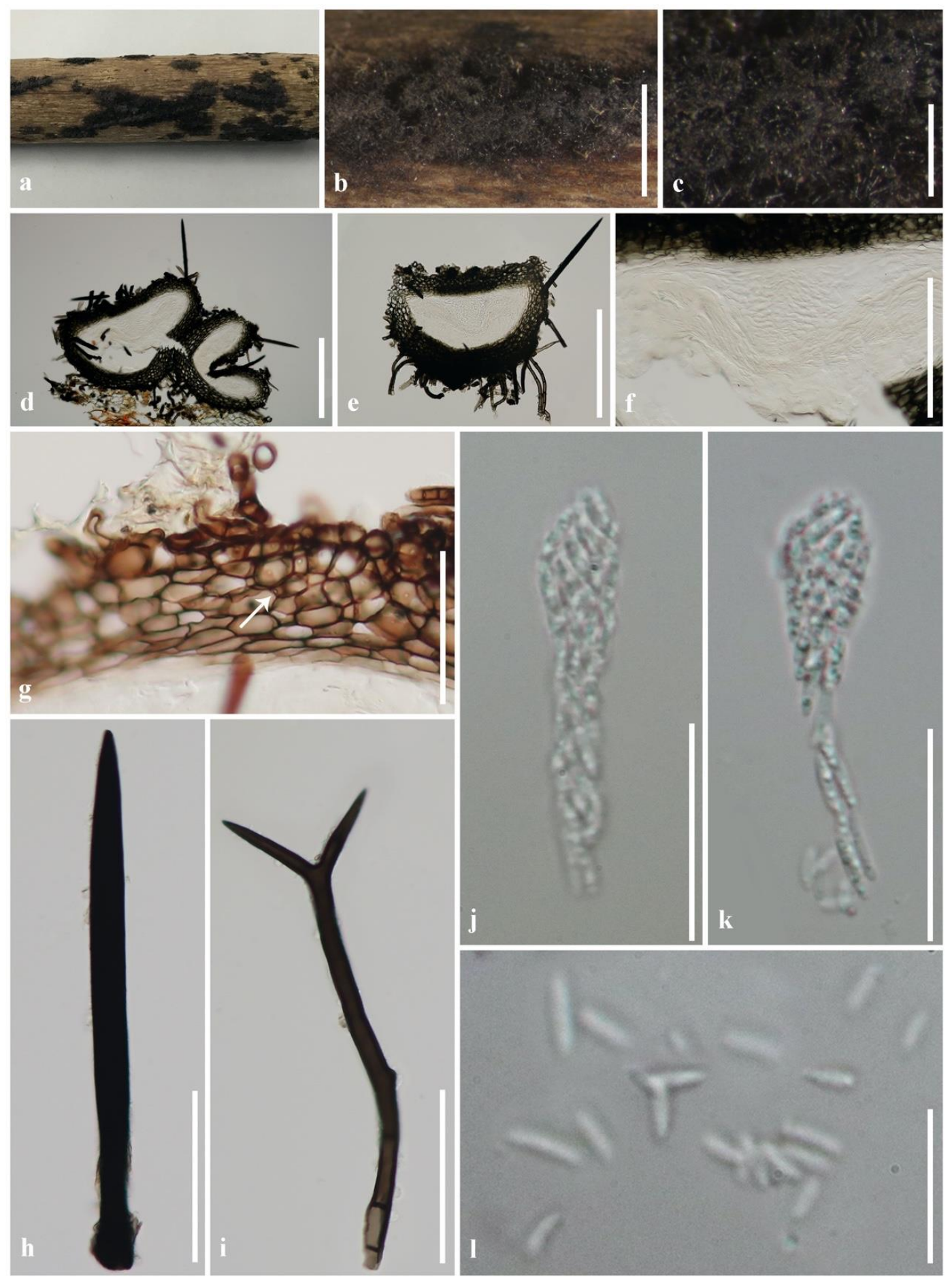

Figure 7 - Neotrotteria pulchella: (IMI-354793). a Ascomata on decorticated wood. b-c Ascomata. d-e Ascomata cross section. f Quellkörper. g Peridium (arrow indicates Munk pores between cells). h Seta. i Hypha with dichotomously branched end. j-k Asci. 1 Ascospores. Scale bars: $\mathrm{b}=2 \mathrm{~mm}, \mathrm{c}=500 \mu \mathrm{m}, \mathrm{d}-\mathrm{e}=200 \mu \mathrm{m}, \mathrm{f}=100 \mu \mathrm{m}, \mathrm{g}-\mathrm{i}=50 \mu \mathrm{m}, \mathrm{j}-\mathrm{k}=20 \mu \mathrm{m}, \mathrm{l}=10 \mu \mathrm{m}$. 
Pseudomicrothecium Y. Marín, Stchigel, Guarro \& Cano, in Marin-Felix et al., MycoKeys 44: 114 (2018)

Saprobic on Tuber. Sexual morph: Ascomata immersed, globose to subglobose, without an external opening, scattered, pale brown to brown, membranaceous, translucent, glabrous or setose. Peridium membranaceous, composed of pale brown to hyaline cells of textura angularis. Asci 2spored, clavate to cylindrical, evanescent. Ascospores hyaline becoming dark brown, ellipsoidal to citriform, usually umbonate and truncate at both ends, smooth-walled, with a terminal indistinct germ pore at each end, mostly with guttules. Sexual morph: Undetermined (adapted from Fan et al. 2012).

Notes - The monotypic Pseudomicrothecium was established by Marin-Felix et al. (2018) and is characterized by ascomata without an external opening and 2-spored asci with ellipsoidal to citriform ascospores (Fan et al. 2012). In this study, P. subterraneum nests in Ceratostomataceae (80\%ML/1.00BY, Fig. 1) based on phylogenetic result.

Pseudomicrothecium subterraneum (L. Fan et al.) Y. Marín, Stchigel, Guarro \& Cano, in MarinFelix et al., MycoKeys 44: 115 (2018)

Basionym - Melanospora subterranea L. Fan, C.L. Hou, P.F. Cannon \& Yu Li, Mycologia 104(6): 1434 (2012)

Facesoffungi number: FoF 10150

Saprobic on Tuber. Sexual morph: Ascomata immersed, globose to subglobose, without an external opening, scattered, pale brown to brown, membranaceous, translucent, glabrous or setose. Peridium membranaceous, composed of pale brown to hyaline cells of textura angularis. Asci 2spored, clavate to cylindrical, evanescent. Ascospores hyaline becoming dark brown, ellipsoidal to citriform, usually umbonate and truncate at both ends, smooth-walled, with a terminal indistinct germ pore at each end, mostly with guttules. Sexual morph: Undetermined (adapted from Fan et al. 2012).

Known hosts and distribution - on decayed tissues of Tuber huidongense and T. indicum in China (type locality) (Fan et al. 2012).

Notes - Marin-Felix et al. (2018) transferred Melanospora subterranea as generic type of Pseudomicrothecium based on phylogenetic result.

Pustulipora P.F. Cannon, Mycotaxon 15: 526 (1982)

Saprobic on wood. Sexual morph: Ascomata perithecial, superficial, globose to subglobose, gregarious, brown to dark brown, membranaceous, covered by white tomentum, ostiolate. Peridium membranaceous, composed of yellow to pale brown cells of textura angularis. Asci 4-spored, clavate to obovoid, evanescent. Ascospores bi-seriate, brown, ellipsoidal to citriform, usually umbonate and truncate at both ends, smooth-walled, with a germ pore at each end, sometimes surrounded by hyaline cushion-like structures. Sexual morph: Undetermined (adapted from Cannon 1982).

Notes - The monotypic genus Pustulipora was introduced by Cannon (1982) and typified by P. corticola. This species was considered as Melanospora theleboloides (Fig. 8a-d). However, Cannon (1982) stated that $P$. corticola is different from $M$. theleboloides with glabrous ascomata, whereas, the former has tomentose ascomata.

Pustulipora corticola P.F. Cannon, Mycotaxon 15: 526 (1982)

Fig. $8 \mathrm{e}-\mathrm{f}$

Facesoffungi number: FoF 10151

Saprobic on wood or leaves. Sexual morph: Ascomata perithecial, superficial, globose to subglobose, gregarious, brown to dark brown, membranaceous, covered by white tomentum, ostiolate. Peridium membranaceous, composed of yellow to pale brown cells of textura angularis. Asci 4-spored, clavate to obovoid, evanescent. Ascospores bi-seriate, brown, ellipsoidal to citriform, usually umbonate and truncate at both ends, smooth-walled, with a germ pore at each 
end, sometimes surrounded by hyaline cushion-like structures. Sexual morph: Undetermined (adapted from Cannon 1982).

Known hosts and distribution - on decayed wood in the UK (type locality) (Cannon 1982).

Notes - We re-examined the type of Melanospora theleboloides (Germany, Hessen, Rheingau, in the castle park near Hattenheim, on decaying leaves, K.W.G. Fuckel, G-326774/1G00127866, holotype), but its ascomata are too dry to observe any complete structure. However, we drew the ascus and ascospores of Pustulipora corticola with reference to Cannon (1982).

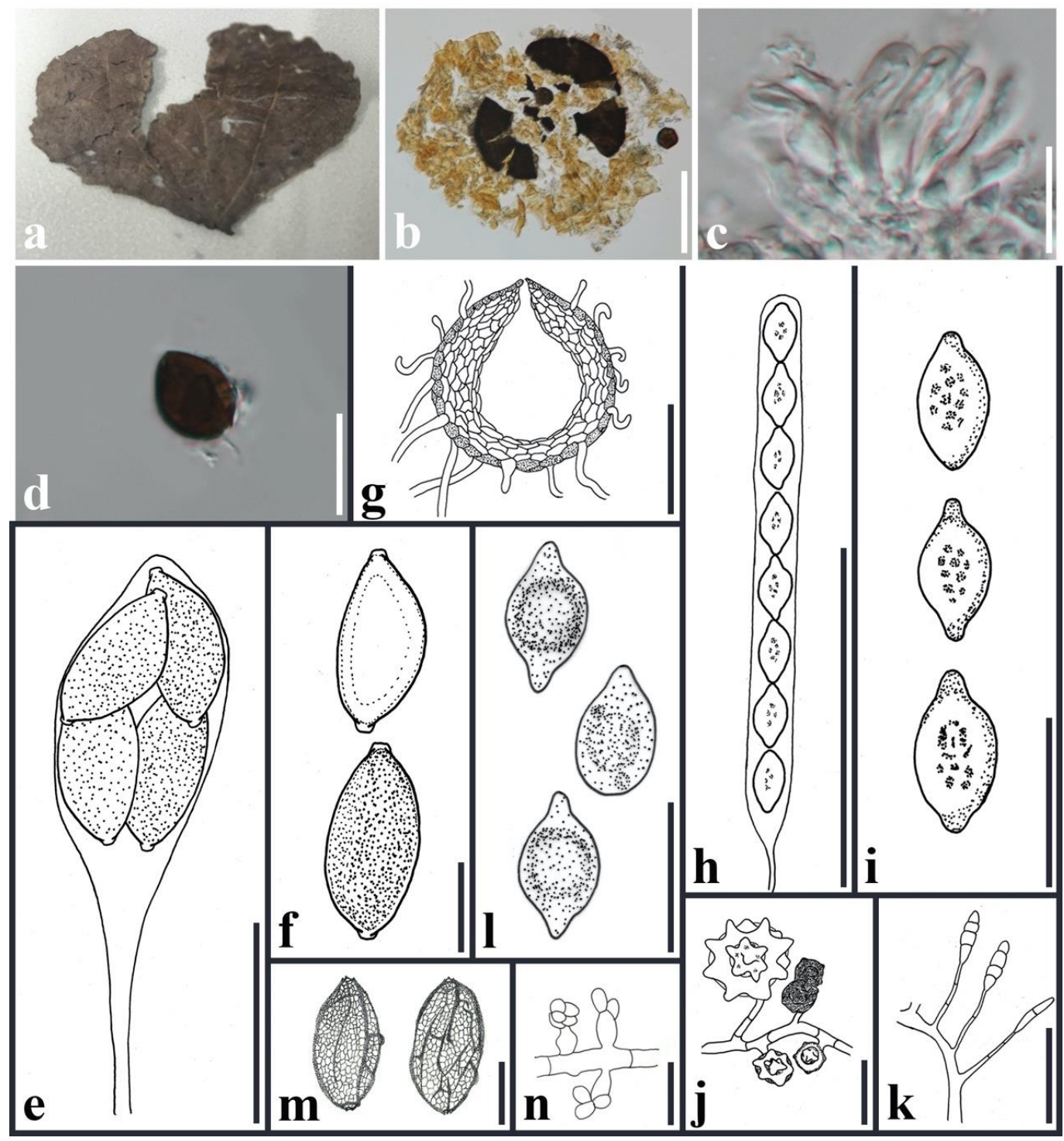

Figure 8 - Melanospora theleboloides: a-d (G-326774/1-G00127866, holotype). a Material. b Crushed ascomata. c Immature asci. d ascospores; Pustulipora corticola: e-f (redrawn from Cannon 1982). e Ascus. f Ascospores; Erythrocarpon microstomum: g-k (redrawn from Zukal 1885). g Ascoma cross section. h Ascus. i Ascospores. $\mathrm{j}-\mathrm{k}$ Two types of conidiophores with conidia; Microthecium zobelii: 1 (redrawn from Corda 1842, Udagawa \& Cain 1969). 1 Ascospores. Microthecium foveolatum: $\mathrm{m}-\mathrm{n}$ (redrawn from Hawksworth \& Udagawa 1977). m Ascospores with irregular ridges. $\mathrm{n}$ Conidiophores with conidia. Scale bars: $\mathrm{g}=200 \mu \mathrm{m}, \mathrm{b}=100 \mu \mathrm{m}, \mathrm{e}, \mathrm{k}=50 \mu \mathrm{m}$, $\mathrm{c}-\mathrm{d}, \mathrm{f}, \mathrm{h}, \mathrm{j}, \mathrm{l}=20 \mu \mathrm{m}, \mathrm{i}, \mathrm{m}-\mathrm{n}=10 \mu \mathrm{m}$.

\section{Rhytidospora Jeng \& Cain, Mycotaxon 5(1): 278 (1977)}

Coprophilous. Sexual morph: Ascomata solitary, superficial, globose, without an external opening, yellow to pale orange, membranaceous, translucent, glabrous or hairy. Peridium cephalothecoid, irregularly polygonous pattern on surface view, membranaceous, outer layer 
composed of yellow to pale orange cells of textura angularis; inner layer composed of hyaline cells of textura prismatica. Paraphyses absent. Asci 2-, 4- or 8-spored, unitunicate, subglobose to clavate, evanescent. Ascospores hyaline becoming dark brown or olivaceous brown, broadly fusiform to ellipsoidal, aseptate, verrucose to tuberculate to wrinkled, sometimes with pits on surface, with germ pore at each end and a large guttule. Asexual morph: Undetermined (adapted from Jeng \& Cain 1977, Krug \& Jeng 1979, Valldosera \& Guarro 1994).

Notes - Rhytidospora was established by Jeng \& Cain (1977) and typified by Rhytidospora tetraspora. It is characterized by translucent, glabrous ascomata and broadly fusiform ascospores with wrinkled or pitted surface (Jeng \& Cain 1977, Krug \& Jeng 1979, Valldosera \& Guarro 1994). These characters were considered similar to Melanospora (Jeng \& Cain 1977), and we found that they are also similar to Neurospora and Sordaria. However, molecular data for this genus is lacking.

Rhytidospora tetraspora Jeng \& Cain, Mycotaxon 5(1): 279 (1977)

Fig. 9

Facesoffungi number: FoF 10058

Coprophilous. Sexual morph: Ascomata 130-250 $\mu \mathrm{m}(\bar{x}=185 \mu \mathrm{m}, \mathrm{n}=10)$ diam., solitary, superficial, globose, without an external opening, yellow to pale orange, membranaceous, translucent, glabrous. Peridium 45-80 $\mu \mathrm{m}(\bar{x}=60 \mu \mathrm{m}, \mathrm{n}=20)$, cephalothecoid, irregularly polygonous pattern on surface view, membranaceous, comprising three layers, outer layer composed of yellow to pale orange cells of textura globulosa; middle layer composed of yellow to pale orange cells of textura angularis; inner layer composed of hyaline cells of textura prismatica. Asci (21-)25-32(-35) $\times(14-) 18-20(-23) \mu \mathrm{m}(\bar{x}=28 \times 19 \mu \mathrm{m}, \mathrm{n}=10)$ ascospore-bearing part, 4spored, unitunicate, obovoid to clavate, evanescent. Ascospores $9.5-14(-18) \times(7-) 8-10(-12.5) \mu \mathrm{m}$ $(\bar{x}=13 \times 9 \mu \mathrm{m}, \mathrm{n}=50)$, bi-seriate, hyaline becoming dark brown or olivaceous brown, broadly fusiform to ellipsoidal, aseptate, verrucose to tuberculate, with germ pore at each end and a large guttule. Asexual morph: Undetermined.

Material examined - Venezuela, Edo. Scure, trail between Manacal and Los Pocitos, NW of Irapa, 905'00' N/62'41'00' 'W, on burro dung, 13 July 1972, K.P. Dumont, R.F. Cain, G.J. Samuels, G. Morillo and J. Farfan (TRTC-052086, holotype); Sweden, Uppland, Häverö, Prästăngen, in a grove of deciduous trees, on old horse dung in moist chamber, 17 June 1976, N. Lundqvist (UPS-UPS:BOT:F-132032).

Known hosts and distribution - on burro dung in Venezuela (type locality) (Jeng \& Cain 1977); on horse dung in Sweden.

Notes - We re-examined the holotype (052086) and an authentic specimen (F-132032) which was collected by Lundqvist, and provide their illustration.

Scopinella Lév., in Orbigny, Dict. Univ. Hist. Nat. 8: 493 (1846)

Saprobic on wood, leaves and/or isolated from soil, or coprophilous or fungicolous. Sexual morph: Ascomata perithecial, solitary to gregarious, superficial to semi-immersed, sometimes sitting on a dense mass of brown hyphae, globose to subglobose venter, usually with long necks, brown to dark brown, semi-translucent, membranaceous, glabrous or hairy, ostiolate. Peridium membranaceous, composed of brown cells of textura angularis. Paraphyses absent or filiform, septate. Asci 2-, 8- to multi-spored, clavate to cylindrical. Ascospores olivaceous brown to dark brown, ellipsoidal, cuboid-ellipsoidal to Z-shaped, verrucose or smooth-walled, usually with two prominent longitudinal germ slits. Sexual morph: Undetermined (adapted from Hawksworth 1975, van Geel \& Aptroot 2006, Pastirčák \& Pastirčáková 2007, Sanchez et al. 2012).

Notes - Scopinella was introduced by Léveillé (1847) based on S. barbata having ascomata with long necks, 8-spored asci and cuboid-ellipsoidal ascospores. Saccardo (1891) proposed a second species based on Melanospora pleiospora, which has multi-spored asci and ellipsoidal ascospores. However, Hawksworth (1975) clarified Scopinella and did not include S. pleiospora. Seven Scopinella species with cuboid-ellipsoidal ascospores were subsequently introduced (Hawksworth 1975, Cannon \& Hawksworth 1982, van Geel \& Aptroot 2006, Pastirčák \& 
Pastirčáková 2007, Sanchez et al. 2012, Marin-Felix et al. 2018, Index Fungorum 2021). Zhang \& Blackwell (2002) sequenced S. solani (CBS 770.84) which nests in Stachybotryaceae (Hypocreales) in our phylogenetic study (Fig. 1). This genus was placed in Ceratostomataceae because of its ascomata with long necks (Pastirčák \& Pastirčáková 2007, Wijayawardene et al. 2020, Hyde et al. 2020e). Lumbsch \& Huhndorf (2010) placed this genus in Hypocreales. In this study, we propose to place Scopinella in Ceratostomataceae pending molecular data of type species.
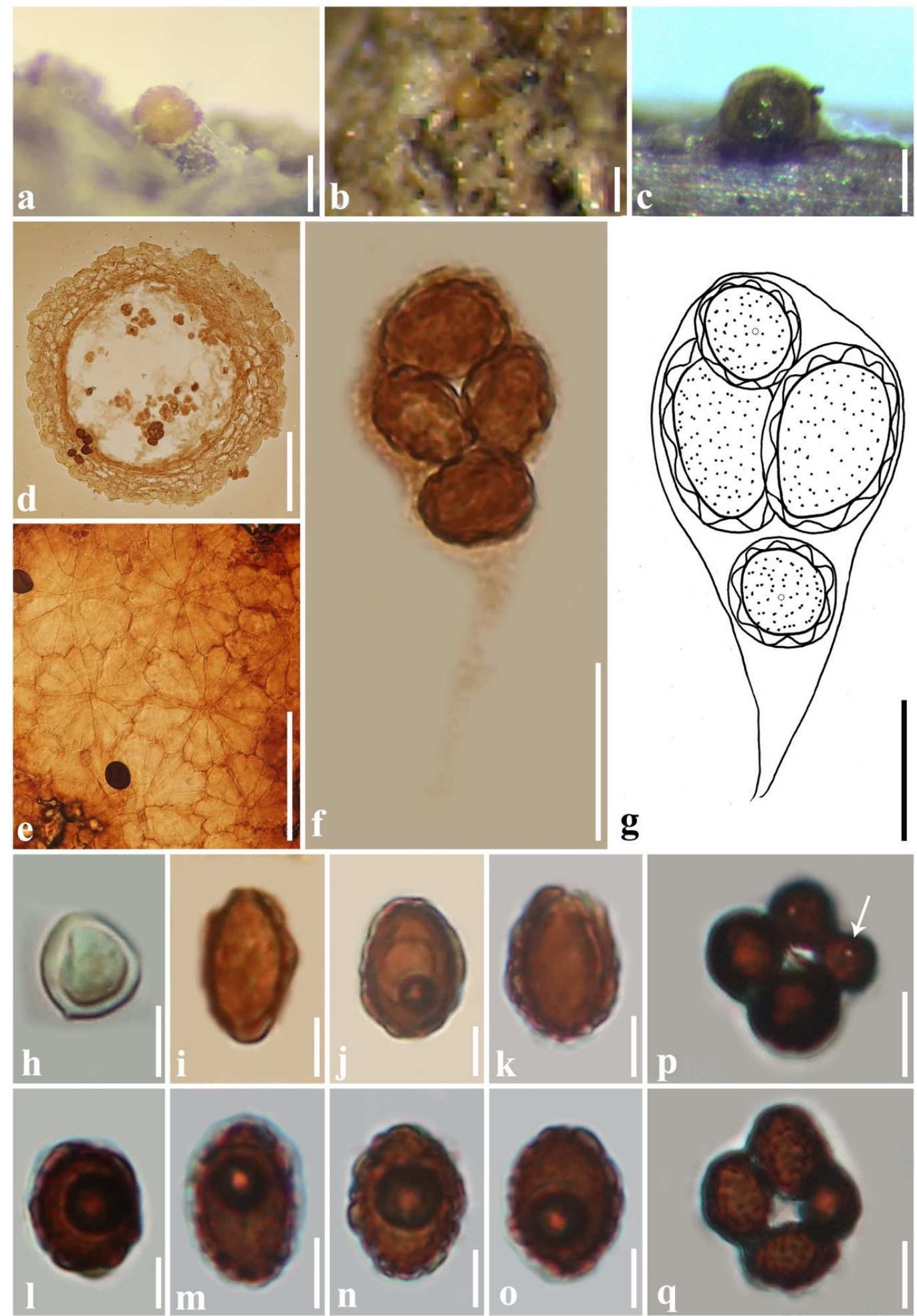

Figure 9 - Rhytidospora tetraspora: a-b, d-g, i-o (TRTC-052086, holotype); c, h, p-q (UPSUPS:BOT:F-132032). a-c Superficial ascomata on the host. d Ascoma cross section. e Peridium 
surface view. $\mathrm{f}-\mathrm{g}$ Asci. $\mathrm{h}-\mathrm{q}$ Ascospores (p arrow indicates germ pore). Scale bars: $\mathrm{a}-\mathrm{b}=200 \mu \mathrm{m}$, $\mathrm{c}-\mathrm{e}=100 \mu \mathrm{m}, \mathrm{f}=20 \mu \mathrm{m}, \mathrm{g}-\mathrm{h}, \mathrm{p}-\mathrm{q}=10 \mu \mathrm{m}, \mathrm{i}-\mathrm{o}=5 \mu \mathrm{m}$.

Scopinella barbata (Pers.) Lév. ex Sacc., Michelia 1(no. 3): 284 (1878)

Fig. $15 g-h$

Facesoffungi number: FoF 10152

Saprobic on leaves. Sexual morph: Ascomata perithecial, solitary to scattered, superficial to semi-immersed, globose to subglobose venter, with a long neck, dark brown to black, semitranslucent, membranaceous, hairy, ostiolate. Necks cylindrical to conical, composed of fasciculate, cylindrical, brown to dark brown, septate hyphae, straight or slightly curved, with a jagged apex, ascospores usually accumulating in necks. Peridium membranaceous, composed of brown cells of textura angularis. Paraphyses absent. Asci 8-spored, unitunicate, clavate, with short pedicel. Ascospores irregular to bi-seriate, brown to dark brown, cuboid-ellipsoidal, smooth-walled, with two prominent longitudinal germ slits. Sexual morph: Undetermined (adapted from Hawksworth 1975)

Known hosts and distribution - on fallen leaves of Quercus, Castanea, Potentilla and Rhododendron in Algeria, Canada, France, Germany (type locality), Italy, Switzerland, the UK and Pakistan (Hawksworth 1975, van Geel \& Aptroot 2006).

Notes - Scopinella barbata was introduced as type species (Léveillé 1847, Saccardo 1878). This genus was ignored until Hawksworth (1975) clarified Chaetoceratostoma hispidum as a synonym of $S$. barbata based on their authentic materials. However, molecular data for this species is unavailable. We were unable to obtain authentic material; therefore, a hand-drawing of ascus and ascospores are provided (Fig. 15g-h) based on Hawksworth (1975).

Setiferotheca Matsush., Matsush. Mycol. Mem. 8: 34 (1995)

Saprobic on litter in forest. Sexual morph: Subiculum white, composed of hyaline, septate hyphae. Ascomata perithecial, superficial, gregarious to solitary, globose to subglobose, pale brown to brown, translucent, membranaceous, with inconspicuous ostioles, surrounded by straight, rigid, tapering, dark brown to black setae. Peridium membranaceous, composed of pale brown cells of textura angularis. Asci 4- to 8-spored, clavate to cylindrical, evanescent. Ascospores usually biseriate, brown, ellipsoidal, smooth-walled, rounded apex, terminal apiculate base with germ pore. Sexual morph: Undetermined (adapted from Matsushima 1995).

Notes - Setiferotheca was established as a genus related to Sphaeroderma (= Melanospora), although the former has ascospores with a germ pore at one end, and the latter has one germ pore at each end (Matsushima 1995). However, no molecular data is available for the Setiferotheca.

Setiferotheca nipponica Matsush., Matsush. Mycol. Mem. 8: 35 (1995)

Fig. $15 \mathrm{k}-\mathrm{m}$

Facesoffungi number: FoF 10153

Saprobic on litter in forest. Sexual morph: Subiculum white, composed of hyaline, septate hyphae. Ascomata perithecial, superficial, gregarious to solitary, globose to subglobose, pale brown to brown, translucent, membranaceous, with inconspicuous ostioles, surrounded by straight, rigid, tapering, dark brown to black setae. Peridium membranaceous, composed of pale brown cells of textura angularis. Asci 4- to 8-spored, clavate to cylindrical, evanescent. Ascospores usually biseriate, brown, ellipsoidal, smooth-walled, rounded apex, terminal apiculate base with germ pore. Sexual morph: Undetermined (adapted from Matsushima 1995).

Known hosts and distribution - on litter in forest in Japan (type locality) (Matsushima 1995).

Notes - The monotypic Setiferotheca is typified by S. nipponica, and this species was found in the litter in forests of Ise-shi, Amami-ohshima and Minakuchi-choh in Japan from 1993 to 1995 (Matsushima 1995).

Syspastospora P.F. Cannon \& D. Hawksw., J. Linn. Soc., Bot. 84(2): 152 (1982)

Parasitic on various moniliaceous hyphomycetes, or isolated from soil, or lichenicolous. Sexual morph: Ascomata perithecial or without an external opening, solitary, superficial to 
immersed, globose to subglobose, sometimes with long necks, pale brown to brown, membranaceous, glabrous or setose or hairy, with or lacking ostioles. Necks absent or cylindrical, composed of fasciculate, cylindrical, septate hyphae, straight or slightly curved. Peridium membranaceous, composed of pale brown to brown cells of textura angularis. Asci 8-spored, unitunicate, clavate, evanescent. Ascospores irregular or bi-seriate, hyaline becoming brown or olivaceous brown, broadly fusiform to cylindrical to doliiform, truncate at both ends, aseptate, smooth-walled or with reticulate ribs on surface, with a large depressed germ pore at each end, mostly with guttules. Asexual morph: Hyphomycetous. Mycelium consisting of hyaline to yellowish brown, branched, septate, smooth-walled hyphae. Chlamydospores terminal to intercalary, globose to ovoid, hyaline to brown (adapted from Cannon \& Hawksworth 1982, Horie et al. 1986, García et al. 2002, Etayo \& Sancho 2008).

Notes - Syspastospora was established as a genus similar to Melanospora, and its generic type, $S$. parasitica, has cylindrical to doliiform ascospores with large terminal depressed germ pores at each end, whereas Melanospora has ellipsoidal to citriform ascospores (Cannon \& Hawksworth 1982). The strain of S. parasitica nested in Hypocreales (Zhang \& Blackwell 2002). This genus was accepted as a member of Ceratostomataceae based on multi-gene analyses (MarinFelix et al. 2018, Hyde et al. 2020e, Wijayawardene et al. 2020). In this study, Syspastospora is sister to Gonatobotrys and Vittatispora in Ceratostomataceae (54\%ML/0.99BY, Fig. 1).

Syspastospora parasitica (Tul.) P.F. Cannon \& D. Hawksw., J. Linn. Soc., Bot. 84(2): 152 (1982)

Fig. $15 \mathrm{f}$

Basionym - Sphaeronaema parasiticum Tul. [as 'parasitica'], Annls Sci. Nat., Bot., sér. 4 8: 40 (1857)

Facesoffungi number: FoF 10154

Parasitic on various moniliaceous hyphomycetes. Sexual morph: Ascomata perithecial, solitary, superficial to immersed, globose to subglobose, with long necks, pale brown to brown, membranaceous, glabrous or hairy, ostiolate. Necks cylindrical, composed of fasciculate, cylindrical, septate hyphae, straight or slightly curved. Peridium membranaceous, composed of pale brown to brown cells of textura angularis. Asci 8-spored, unitunicate, clavate, evanescent. Ascospores irregular or bi-seriate, hyaline becoming brown or olivaceous brown, cylindrical to doliiform, truncate at both ends, aseptate, smooth-walled or with reticulate ribs on surface, with a depressed germ pore at each end, mostly with guttules. Asexual morph: Undetermined (adapted from Cannon \& Hawksworth 1982).

Known hosts and distribution - on various moniliaceous hyphomycetes, e.g. Beauveria, Cephalosporium, Paecilomyce, Hirsutella and Verticillium in Canada, Europe, Kenya, South Africa, Sri Lanka, Trinidad and the USA (Cannon \& Hawksworth 1982).

Notes - Syspastospora parasitica was initially introduced as Sphaeronema parasiticum, and then transferred as Melanospora parasitica based on its ascomata with long hairy necks and ascospores with truncate ends being similar to Melanospora (Tulasne 1857, Tulasne \& Tulasne 1865). However, Sys. parasitica with cylindrical to doliiform ascospores differs from Melanospora species with ellipsoidal to citriform ascospores (Cannon \& Hawksworth 1982). In this study, Sys. parasitica is basal to Gonatobotrys simmplex and Vittatispora coorgii (54\%ML/0.99BY, Fig. 1) in Ceratostomataceae.

Vittatispora P. Chaudhary, J. Campb., D. Hawksw. \& K.N. Sastry, Mycologia 98(3): 461 (2006)

Isolated from soil. Sexual morph: Ascomata perithecial, solitary or gregarious, superficial to semi-immersed, globose, with long necks, pale brown to brown, membranaceous, translucent, glabrous or hairy, ostiolate. Necks cylindrical, composed of fasciculate, cylindrical, pale brown hyphae, straight or slightly curved, ascospores usually accumulating in translucent necks. Peridium membranaceous, composed of brown cells of textura angularis. Asci 8-spored, unitunicate, clavate, evanescent. Ascospores hyaline becoming brown or dark brown, ellipsoidal to citriform, apiculate, 
aseptate, smooth-walled, with germ pore surrounded by a raised rim and connected by a prominent longitudinal ridge. Asexual morph: Undetermined (adapted from Chaudhary et al. 2016).

Notes - The monotypic genus Vittatispora (type $V$. coorgii) has translucent ascomata with ellipsoidal to citriform ascospores with germ pores surrounded by a raised rim and connected by a prominent longitudinal ridge (Chaudhary et al. 2006). These characters are similar to Melanospora. However, Chaudhary et al. (2006) analyzed LSU sequence data and proved that Vittatispora is independent of Melanospora. In this study, Vittatispora is sister to Gonatobotrys in Ceratostomataceae (56\% ML/0.97BY, Fig. 1).

Vittatispora coorgii P. Chaudhary, J. Campb., D. Hawksw. \& K.N. Sastry, Mycologia 98(3): 463 (2006)

Facesoffungi number: FoF 10155

Fig. $150-\mathrm{q}$

Isolated from soil. Sexual morph: Ascomata perithecial, solitary or gregarious, superficial to semi-immersed, globose, with long necks, pale brown to brown, membranaceous, translucent, glabrous or hairy, ostiolate. Necks cylindrical, composed of fasciculate, cylindrical, pale brown hyphae, straight or slightly curved, ascospores usually accumulating in translucent necks. Peridium membranaceous, composed of brown cells of textura angularis. Asci 8-spored, unitunicate, clavate, evanescent. Ascospores hyaline becoming brown or dark brown, ellipsoidal to citriform, apiculate, aseptate, smooth-walled, with germ pore surrounded by a raised rim and connected by a prominent longitudinal ridge. Asexual morph: Undetermined (adapted from Chaudhary et al. 2016).

Known hosts and distribution - on soil in India (type locality) (Chaudhary et al. 2006)

Notes - Vittatispora coorgii is similar to Syspastospora tropicalis has translucent ascomata, clavate asci and ascospores with germ pore surrounded by a raised rim and connected by a prominent longitudinal ridge, but $S$. tropicalis has cylindrical to doliiform ascospores (García et al. 2002, Chaudhary et al. 2006). In this study, Syspastospora is basal to Gonatobotrys and Vittatispora based on phylogenetic result (54\%ML/0.99BY, Fig. 1).

Chaetosphaerellaceae Huhndorf, A.N. Mill. \& F.A. Fernández, in Huhndorf, Miller \& Fernández, Mycol. Res. 108(12): 1387 (2004)

Saprobic on wood. Sexual morph: Subiculum absent or extensive, composed of densely clustered, abundant, dark brown to black, septate, rigid, branched, spinulose hyphae with dichotomously branched, tapering ends. Ascomata perithecial or without an external opening, scattered or densely gregarious, superficial or sitting on or in a subiculum, turbinate, globose to subglobose, carbonaceous or coriaceous, tuberculate, black, glabrous or with brown, cylindrical, spinous setae or black tooth-like spines, ostiolate with papilla or lacking ostioles with Quellkörper, collabent or not. Peridium carbonaceous to coriaceous to membranaceous, composed of brown to hyaline cells of textura angularis to textura prismatica, sometimes Munk pore present. Paraphyses numerous, filiform or broadly cylindrical, septate, inflated, sometimes present only in young ascomata. Asci 8-spored, unitunicate, clavate to cylindrical, with long or short pedicel, apical ring or inconspicuous, evanescent. Ascospores uni- or bi-seriate or overlapping, hyaline, becoming brown or brown median cells and hyaline end cells, ellipsoidal to cylindrical, 1-3-septate, smoothwalled, mostly with guttules. Asexual morph: Hyphomycetous. Conidiophores macronematous, mononematous, brown to dark brown, pale brown towards the apex, occasionally pale towards the base, branched, septate. Conidiogenous cells terminal and intercalary, polyblastic, holoblastic, brown, swollen, globose to subglobose. Conidia solitary, multiple conidia are produced serially from a retrogressive locus, usually central cell dark brown and end cell subhyaline to hyaline, 1-3septate, oval to ellipsoidal (adapted from Müller \& Booth 1972, Sivanesan 1974, Réblová 1999a, b).

Type genus - Chaetosphaerella E. Müll. \& C. Booth

Notes - Chaetosphaerellaceae was established by Huhndorf et al. (2004b) and initially accommodated Chaetosphaerella and Crassochaeta based on phylogenetic results. Subsequently, Mugambi \& Huhndorf (2010) found that Spinulosphaeria exists independently in Coronophorales 
based on LSU sequence data analysis. These three genera were accepted in Chaetosphaerellaceae, because they have similar characteristics of turbinate, tuberculate, black ascomata sitting on hyphal subiculum, clavate asci and ellipsoidal ascospores, and they clustered based on multi-gene analyses (Maharachchikumbura et al. 2015, 2016, Hyde et al. 2017). In this study, Chaetosphaerellaceae clade, which accommodates Chaetosphaerella, Crassochaeta and Spinulosphaeria, nests in Coronophorales (99\%ML/1.00BY, Fig. 1).

Chaetosphaerella E. Müll. \& C. Booth, Trans. Br. mycol. Soc. 58(1): 76 (1972)

Saprobic on wood. Sexual morph: Subiculum extensive, composed of densely clustered, abundant, dark brown to black, septate, rigid, branched, spinulose hyphae with dichotomously branched, tapering ends. Ascomata perithecial, scattered or densely gregarious, superficial or sitting on or in a subiculum, turbinate, globose to subglobose, carbonaceous, tuberculate, black, glabrous or with brown, cylindrical, spinous setae, ostiolate with papilla, periphysate. Peridium carbonaceous to membranaceous, composed of dark brown to brown to hyaline cells of textura angularis to textura prismatica, Munk pore present. Paraphyses broadly cylindrical, septate, inflated, sometimes present only in young ascomata. Asci 8-spored, unitunicate, cylindrical, apical ring indistinct, with short pedicel. Ascospores bi-seriate, hyaline, aseptate, becoming brown median cells and hyaline end cells, 3-septate, slightly constricted at the middle septum, ellipsoidal to cylindrical, slightly curved, smooth-walled, mostly with guttules. Asexual morph: Hyphomycetous. Conidiophores macronematous, mononematous, brown to dark brown, pale brown towards the apex, occasionally pale towards the base, branched, septate. Conidiogenous cells terminal and intercalary, polyblastic, holoblastic, brown, swollen, globose to subglobose. Conidia solitary, multiple conidia are produced serially from a retrogressive locus, usually central cell dark brown and end cell subhyaline to hyaline, 1-3-septate, oval to ellipsoidal (adapted from Müller \& Booth 1972, Réblová 1999a).

Notes - Chaetosphaerella was introduced as a genus similar to Chaetosphaeria in having turbinate ascomata with hyphal subiculum and septate ascospores. However, the latter has enteroblastic conidiogenesis, while the former is holoblastic (Müller \& Booth 1972). Réblová (1999a) clarified two Chaetosphaerella species, C. fusca and C. phaeostroma (type), based on their characteristics. Subsequently, the molecular data showed that these two species clustered in Chaetosphaerellaceae, which is distinct from Chaetosphaeria (Chaetosphaeriaceae) (Huhndorf et al. 2004b, Mugambi \& Huhndorf 2010). Its asexual morphs Oedemium and Veramycina were synonymised as Chaetosphaerella (Réblová et al. 2016). We found that the sexual morphs of $C$. fusca and $C$. phaeostroma are similar, but their conidiogenesis differs. Chaetosphaerella phaeostroma has polyblastic conidiogenous cells (Fig. $10 \mathrm{t}$ ) whereas $C$. fusca has the multiple conidia produced serially from a retrogressive locus of hyphae (Fig. $10 \mathrm{u}-\mathrm{y}$ ). Phylogenetically, these two species form Chaetosphaerella clade, sister to Crassochaeta (100\%ML/1.00BY, Fig. 1) in Chaetosphaerellaceae.

Chaetosphaerella phaeostroma (Durieu \& Mont.) E. Müll. \& C. Booth, Trans. Br. mycol. Soc. 58(1): 77 (1972)

Fig. 10a-t

Basionym - Sphaeria phaeostroma Durieu \& Mont., in Durieu, Expl. Sci. Alg., Fl. Algér. 1(livr. 13): 491 (1846)

Facesoffungi number: FoF 01116

Saprobic on wood. Sexual morph: Subiculum extensive, composed of densely clustered, abundant, dark brown to black, septate, rigid, branched, spinulose hyphae (3-)5-7(-10) $\mu \mathrm{m}$ wide, with dichotomously branched, tapering ends. Ascomata 400-460 $\times 200-335 \mu \mathrm{m}(\bar{x}=435 \times 275$ $\mu \mathrm{m}, \mathrm{n}=10$ ), perithecial, scattered or densely gregarious, superficial or sitting on or in subiculum, turbinate, globose to subglobose, carbonaceous, tuberculate, black, glabrous or with brown, cylindrical, spinous setae 7-12 $\mu \mathrm{m}$, ostiolate with papilla, periphysate. Peridium 25-65 $\mu \mathrm{m}$ thick, comprising three layers, outer layer composed of carbonaceous, dark tissues; middle layer composed of membranaceous, dark brown to brown cells of textura angularis, Munk pores present; 
inner layer composed of membranaceous, hyaline cells of textura prismatica. Paraphyses broadly cylindrical, septate, inflated, present only in young ascomata. Asci (90-)115-135(-145) $\times(16-) 17-$ $20(-21) \mu \mathrm{m}(\bar{x}=121 \times 19 \mu \mathrm{m}, \mathrm{n}=30), 8$-spored, unitunicate, cylindrical, apical ring indistinct, with short pedicel. Ascospores (27-)29-32(-36) $\times(5-) 7-8(-9.5) \mu \mathrm{m}(\bar{x}=30 \times 7.5 \mu \mathrm{m}, \mathrm{n}=50)$, biseriate, hyaline, aseptate, becoming brown median cells and hyaline end cells, 3 -septate, slightly constricted at the middle septum, ellipsoidal to cylindrical, slightly curved, smooth-walled, mostly with guttules. Asexual morph: Hyphomycetous. Conidiophores macronematous, mononematous, brown to dark brown, pale brown towards the apex, occasionally pale towards the base, branched, septate. Conidiogenous cells terminal and intercalary, holoblastic, polyblastic, brown, globose to subglobose, with swollen apex. Conidia solitary, brown to dark brown, pale towards the ends, subglobose to ellipsoidal, aseptate when young, becoming 1-3-septate, constricted at the septum, conidial secession with conspicuous denticles on the conidia and conidiogenous cells (adapted from Réblová 1999a).
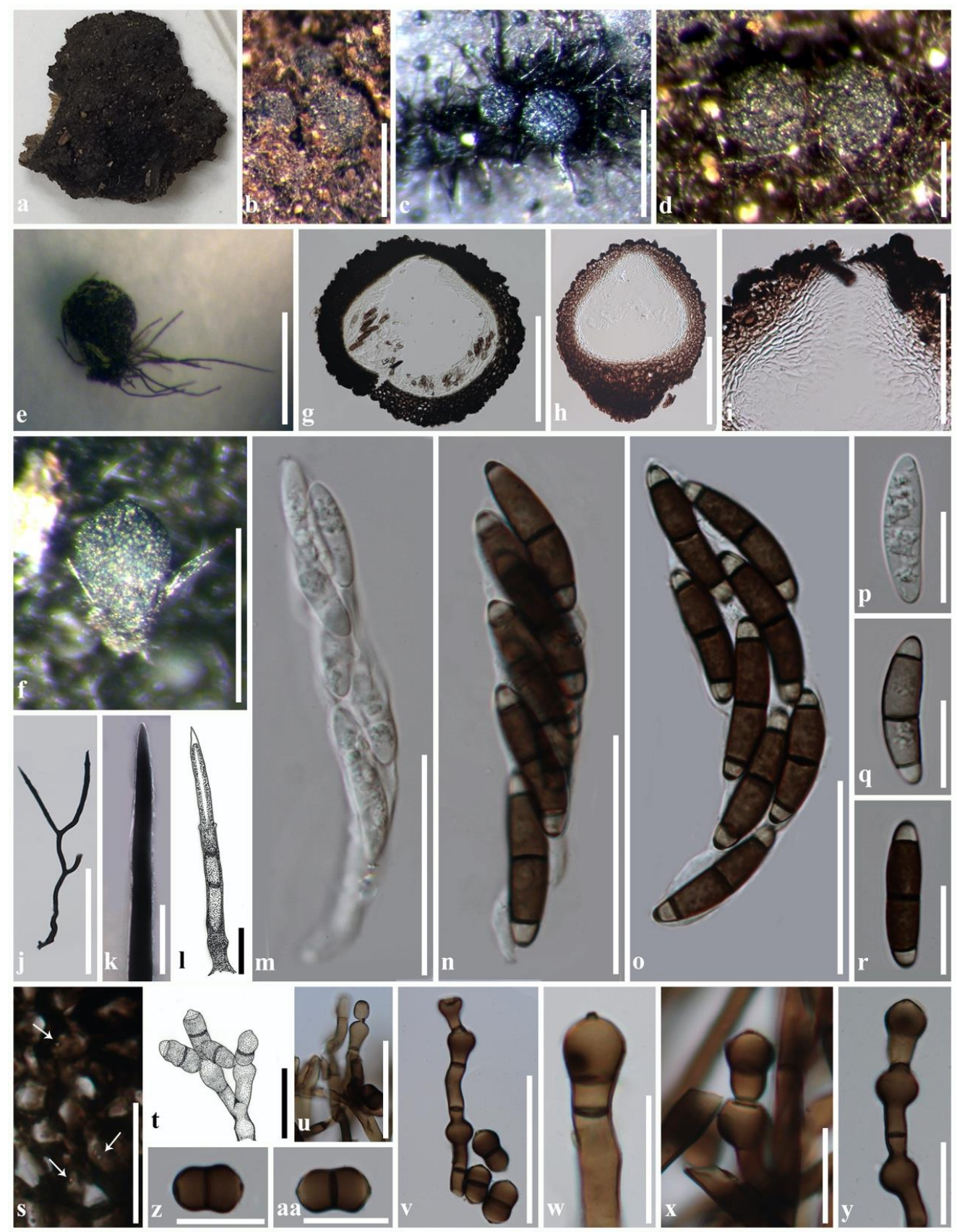

Figure 10 - Chaetosphaerella phaeostroma: a-b, e, g, m-n, p-s (PC-MNHN-PC-PC0167645); c, i (S-F133811); d, o (PC-MNHN-PC-PC0167641); f, h, j (S-F133805); k (S-F133806); 1, t (redrawn 
from Réblová 1999a). a Material. b-d Ascomata on the host. e-f Ascoma with setae. g-h Ascoma cross section. i Ostiole with periphyses. j Branched hypha. k-1 Setae. m-o Asci. p-r Ascospores. s Munk pores (arrow). t Conidiophores with polyblastic conidiogenous cells; Chaetosphaerella fusca: u-aa (UPS-UPS:BOT:F-671626; Russia, Saint Petersburg, Botanical Garden of the Komarov Botanical Institute (lat. 59.96778 long. 30.33167), on dead branches of unknown deciduous tree lying on the surface of ground, 27 August 2009, V. Mel'nik). u-y Conidiophores and conidia produced serially from a retrogressive locus. $\mathrm{z}-\mathrm{aa}$ Conidia. Scale bars: $\mathrm{b}-\mathrm{c}, \mathrm{e}-\mathrm{f}=500 \mu \mathrm{m}, \mathrm{d}, \mathrm{g}=$ $200 \mu \mathrm{m}, \mathrm{h}, \mathrm{j}=100 \mu \mathrm{m}, \mathrm{i}, \mathrm{m}-\mathrm{o}, \mathrm{s}-\mathrm{v}=50 \mu \mathrm{m}, \mathrm{k}-\mathrm{l}, \mathrm{p}-\mathrm{r}, \mathrm{w}-\mathrm{aa}=20 \mu \mathrm{m}$.

Material examined - France, Paris, on dead wood (PC-MNHN-PC-PC0167641); Algeria, on dead wood (PC-MNHN-PC-PC0167645); on dead wood (PC-MNHN-PC-PC0167647); Sweden, Uppland, Gamla Uppsala parish, Fullerö, in a grove by R. Fyris, on decaying fallen branches of ash, associated with Eutypa flavovirens, 9 May 1982, N. Lundqvist (S-F133805); Sweden, Uppland, Stockholm, in the experimental field, on dead wood, 3 May 1920, T. Vestergren (SF133806); Denmark, Sydjylland, Jutland, Haderslev prov., TBU 48, Pamhule forest near Christiansdal ( $=7 \mathrm{~km}$ SW of Haderslev), on Eutypa stroma on Fagus in beech forest, 22 September 1988, N. Lundqvist (S-F133811); Czech Republic, Praha, Cholupice, Bažantnice, on dead wood of Acer negundo, 24 November 1978, F. Kotlaba (PRM-815939); Czech Republic, MährischWeißkirchen (Hranice), Militär-Oberrealschule, on dead wood, November 1913, J. Petrak (PRM875781).

Known hosts and distribution - on decayed wood of Pistacia lentiscus in Algeria (type locality) (Bory de Saint-Vincent \& Durieu de Maisonneuve 1849); on deaded wood of Acer, Broussonetia, Carpinus, Corylus, Fagus, Fraxinus, Hedera, Ilex, Lonnicera, Picea, Pistacia, Prunus, Quercus, Ribes, Salix, Tilia, Ulmus in Austria, China, Czech Republic, Denmark, England, France, Germany, Guyana, Italy, Sweden and the USA (Fuckel 1870a, Saccardo 1883, Winter 1887a, Ellis \& Everhart 1892, Strasser 1911, Teng 1934, Booth 1958, Eriksson 1992, Courtecuisse et al. 1996, Farr et al. 1989, Réblová 1999a).

Notes - Chaetosphaerella phaeostroma was introduced with two types of asexual morphs, Oedemium minus and Veramycina elegans (synanamorph) on natural substrate (Réblová 1999a). Initially, $V$. elegans was described on cultural studies of O. minus (Subramanian 1993), and Réblová (1999a) illustrated that $O$. minus has polyblastic conidiogenous cells and 1-3-septate, ellipsoidal conidia (Fig. 10 t), and V. elegans has single or clustered phialides and hyaline, aseptate, cylindrical conidia. However, more culture characteristics and sequence data are needed to determine their affinities. Figure 1 reveals that $C$. phaeostroma is sister to C. fusca (59\%/ML) in Chaetosphaerellaceae.

\section{Crassochaeta Réblová, Mycotaxon 71: 46 (1999)}

Saprobic on decayed wood. Sexual morph: Subiculum lacking or extensive, composed of densely clustered, dark brown to black, septate, rigid, branched, spinulose hyphae with tapering ends. Ascomata perithecial, superficial, gregarious, dark brown to black, turbinate, conical to ovoidal, tuberculate, collapsing or laterally collapsing when dry, surrounded with dark brown spinous setae, ostiolate with papilla, periphysate. Peridium membranaceous, composed of brown to hyaline cells of textura angularis to textura prismatica, Munk pore absent or present. Paraphyses cylindrical, branched, septate, sometimes constricted at the septa, evanescent. Asci 8-spored, unitunicate, cylindrical, with short pedicel, evanescent. Ascospores fusiform to ellipsoidal, smoothwalled, slightly curved, aseptate, hyaline when young, becoming 3-septate, slightly constricted at the septa, two middle cells brown to dark brown and two end cells hyaline, mostly with guttules. Asexual morph (associated): Conidia solitary, scattered among the hyphae of the subiculum or attached to the surface of the ascomata, ellipsoidal to citriform, slightly apiculate, brown to black, aseptate, with a longitudinal germ slit that nearly connects the two ends (adapted from Réblová 1999b). 
Notes - Réblová (1999b) established Crassochaeta in Trichosphaeriaceae and segregated two Chaetosphaeria species as its members, Crassochaeta fusispora and Cra. nigrita (type), based on their ascomata being larger than Chaetosphaeria. Subsequently, Huhndorf et al. (2004b) analyzed LSU sequence data of Cra. nigrita and found that Crassochaeta is sister to Chaetosphaerella in Coronophorales. Morphologically, Chaetosphaerella and Crassochaeta have similar setose ascomata, cylindrical asci and versicoloured ascospores, but are associated with different asexual morphs. Chaetosphaerella has septate, ellipsoidal conidia, while Crassochaeta has citriform, aseptate conidia with a longitudinal germ slit (Réblová 1999a, b). Thus, Crassochaeta is accommodated in Chaetosphaerellaceae based on morphology and phylogenetic results (Maharachchikumbura et al. 2015, 2016, Hyde et al. 2020e, Wijayawardene et al. 2020). In this study, Crassochaeta is sister to Chaetosphaerella (100\%ML/1.00BY, Fig. 1).

Crassochaeta nigrita (Berk. \& Broome) Réblová, Mycotaxon 71: 48 (1999)

Fig. 11

Basionym - Sphaeria nigrita Berk. \& Broome, J. Linn. Soc., Bot. 14(no. 74): 125 (1873)

Facesoffungi number: FoF 10059

Saprobic on decayed wood. Sexual morph: Subiculum extensive, composed of densely clustered, dark brown to black, septate, rigid, branched, spinulose hyphae 3-7 $\mu \mathrm{m}$ wide, with dichotomously branched or three to multi-branched, tapering ends. Ascomata 330-500 × 265-365 $\mu \mathrm{m}(\bar{x}=400 \times 300 \mu \mathrm{m}, \mathrm{n}=10)$, perithecial, superficial, gregarious, dark brown to black, turbinate, conical to ovoidal, tuberculate, collapsing or laterally collapsing when dry, surrounded with dark brown spinous setae 5-11 $\mu \mathrm{m}$ wide at base, ostiolate with papilla, periphysate. Peridium membranaceous, comprising two layers, outer layer composed of dark brown to brown cells of textura angularis, Munk pore present; inner layer composed of hyaline cells of textura prismatica. Paraphyses cylindrical, branched, septate, evanescent. Asci (110-)120-145(-160) $\times(8-) 10-13(-$ 15) $\mu \mathrm{m}(\bar{x}=140 \times 11.5 \mu \mathrm{m}, \mathrm{n}=30), 8$-spored, unitunicate, cylindrical, apical ring distinct in empty asci, with short pedicel, evanescent. Ascospores 18-23 $\times 7-10 \mu \mathrm{m}(\bar{x}=20 \times 8 \mu \mathrm{m}, \mathrm{n}=50)$, ellipsoidal, smooth-walled, slightly curved, aseptate, hyaline when young, becoming 3-septate, slightly constricted at the septa, two middle cells brown to dark brown, and two end cells hyaline, mostly with guttules. Asexual morph (associated): Conidia solitary, scattered among the hyphae of the subiculum or attached to the surface of the ascomata, ellipsoidal to citriform, slightly apiculate, brown to black, aseptate, with a longitudinal germ slit nearly connects the two ends (adapted from Réblová 1999b).

Material examined - Sri Lanka, Hakgala, Nuwara Eliya Distr., on dead wood, December 1864, G.H.K. Thwaites (IMI-K(M):37405, isotype); China, Hainan, Tan-hsien, on dead wood, 5 December 1934, S.Q. Deng (CUP-CUP-CH 661, paratype).

Known hosts and distribution - on decayed wood in Brazil, Costa Rica, China, Panama, Sri Lanka (type locality) (Réblová 1999b, Huhndorf et al. 2004b).

Notes - Crassochaeta nigrita was initially introduced as Sphaeria nigrita Berk. \& Broome from Sri Lanka (Berkeley \& Broome 1873). Réblová (1999b) proposed that Chaetosphaeria hainanensis is a synonym of Cra. nigrita based on similar characteristics. Subsequently, Huhndorf et al. (2004b) analyzed LSU sequence data of Cra. nigrita and placed Crassochaeta in Chaetosphaerellaceae. We re-examined two well preserved specimens, one is isotype of $S$. nigrita from Sri Lanka identified by Berkeley, and the other is Cha. hainanensis from China was determined as paratype of $C$. nigrita by Huhndorf (mentioned in the label of material). The strains of Cra. nigrita are sister to Chaetosphaerella (100\%ML/1.00BY, Fig. 1).

Neochaetosphaerella Lar.N. Vassiljeva, S.L. Stephenson \& Chernyshev, in Vasilyeva, Chernyshev \& Stephenson, Fungal Diversity 52(1): 192 (2012)

Saprobic on wood. Sexual morph: Subiculum composed of brown, septate, branched, terminal acuminate hyphae. Ascomata perithecial, gregarious, superficial, sitting in a subiculum, oval to subglobose, black, tuberculate, with spiny, septate setae, ostiolate. Peridium composed of brown cells of textura angularis. Paraphyses filiform, evanescent. Asci 8-spored, unitunicate, clavate, 
apex rounded, apical ring inconspicuous, with a short pedicel or sessile, evanescent. Ascospores biseriate to overlapping, broadly allantoid, brown, 3-septate, smooth-walled, guttulate. Asexual morph: Undetermined (adapted from Vasilyeva et al. 2012).
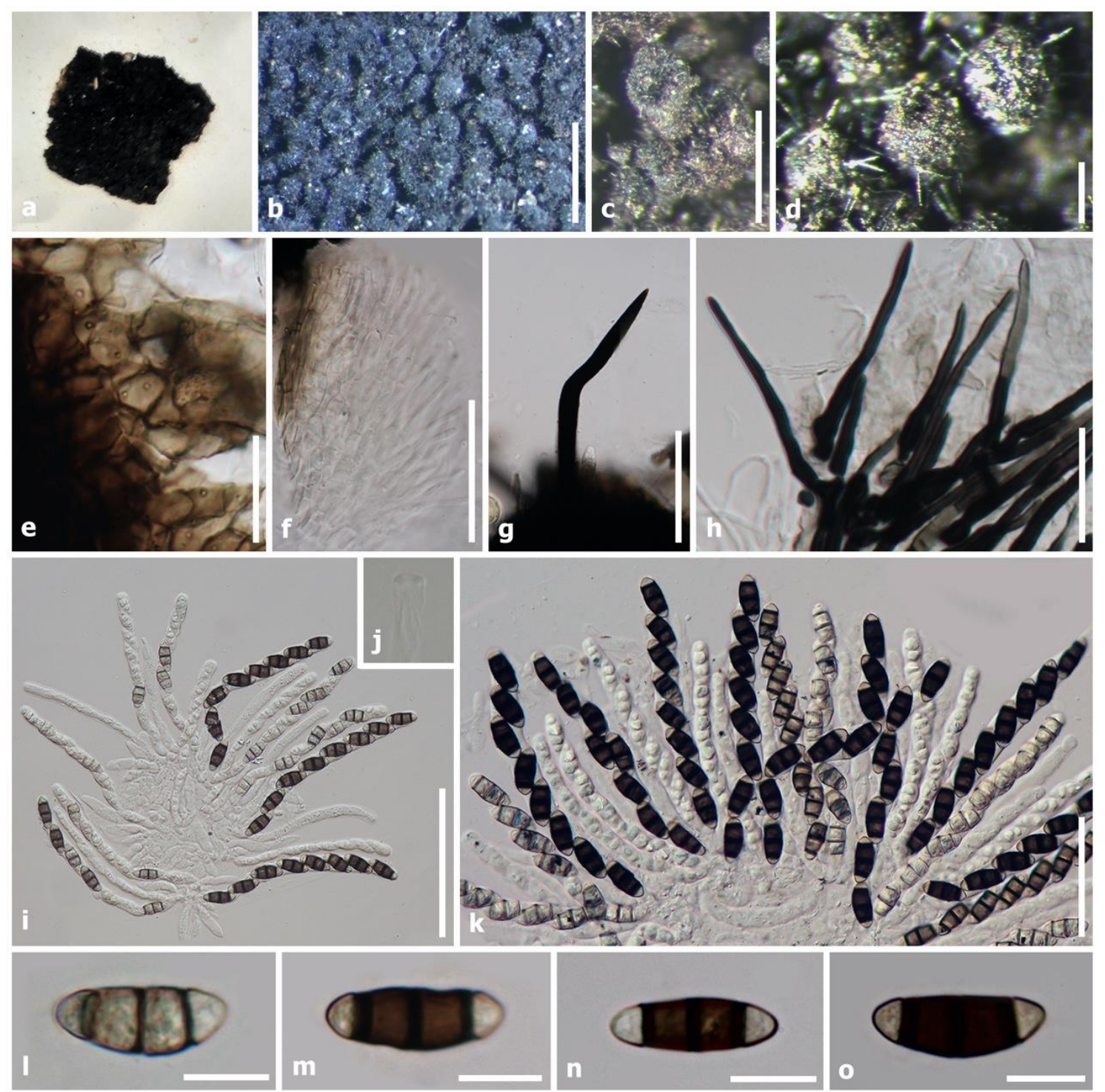

Figure 11 - Crassochaeta nigrita: a-c, h, k-m (IMI-K(M):37405, isotype); d-g, i-j, n-o (CUPCUP-CH 661, paratype). a Material. b Gregarious ascomata. c-d Ascomata on the host. e Peridium with Munk pores. f Periphyses. g Setae. h Hyphae. $\mathrm{i}-\mathrm{k}$ Asci (j apical ring in empty ascus). 1-o Ascospores. Scale bars: $\mathrm{b}=1 \mathrm{~mm}, \mathrm{c}=500 \mu \mathrm{m}, \mathrm{d}=200 \mu \mathrm{m}, \mathrm{i}=100 \mu \mathrm{m}, \mathrm{f}-\mathrm{h}, \mathrm{k}=50 \mu \mathrm{m}, \mathrm{e}=20$ $\mu \mathrm{m}, 1-\mathrm{o}=10 \mu \mathrm{m}$.

Notes - The monotypic Neochaetosphaerella is similar to Chaetosphaerella and Crassochaeta in having tuberculate, setose ascomata and its subiculum is similar to Scortechinia (Scortechiniaceae) with acuminate hyphae. However, Neochaetosphaerella has septate, brown ascospores whereas Chaetosphaerella and Crassochaeta have versicoloured ascospores and Scortechinia has aseptate hyaline ascospores (Vasilyeva et al. 2012). Neochaetosphaerella was initially placed in Coronophorales (Vasilyeva et al. 2012), and then Nitschkiaceae (Maharachchikumbura et al. 2015, Wijayawardene et al. 2020). However, Neochaetosphaerella does not have the hyaline ascospores of Nitschkiaceae. We transfer Neochaetosphaerella to Chaetosphaerellaceae based on the similar tuberculate ascomata, clavate asci and 3-septate ascospores pending molecular data. 
Neochaetosphaerella thaxteriospora Lar.N. Vassiljeva, S.L. Stephenson \& Chernyshev, in Vasilyeva, Chernyshev \& Stephenson, Fungal Diversity 52(1): 192 (2012)

Facesoffungi number: FoF 10156

Saprobic on wood. Sexual morph: Subiculum composed of brown, septate, branched, terminal acuminate hyphae. Ascomata perithecial, gregarious, superficial, sitting in a subiculum, oval to subglobose, black, tuberculate, with spiny, septate setae, ostiolate. Peridium composed of brown cells of textura angularis. Paraphyses filiform, evanescent. Asci 8-spored, unitunicate, clavate, apex rounded, apical ring inconspicuous, with a short pedicel or sessile, evanescent. Ascospores biseriate to overlapping, broadly allantoid, brown, 3-septate, smooth-walled, guttulate. Asexual morph: Undetermined (adapted from Vasilyeva et al. 2012).

Known hosts and distribution - on decayed wood in Russia (type locality) (Vasilyeva et al. 2012).

Notes - Neochaetosphaerella thaxteriospora was initially collected from Russia and is similar to Chaetosphaerella phaeostroma in having setose ascomata and septate, brown ascospores (Vasilyeva et al. 2012).

Spinulosphaeria Sivan., Trans. Br. mycol. Soc. 62(1): 5 (1974)

Saprobic on decayed wood. Sexual morph: Subiculum lacking or extensive, composed of densely clustered, brown to dark brown, septate, branched hyphae. Ascomata superficial, usually sitting on a subiculum, scattered to gregarious, black, with metallic iridescence, turbinate, conical to ovoidal, tuberculate, collapsing when dry, glabrous or surrounded with black, short, tooth-like, usually furcate, spinose ornaments, lacking ostioles, with Quellkörper or not. Peridium carbonaceous or membranaceous, composed of brown to hyaline cells of textura angularis to textura prismatica, Munk pore absent or present. Paraphyses septate, longer than asci, filiform or broad and constricted at the septa, evanescent. Asci 8-spored, unitunicate, clavate, apical ring distinct or indistinct, long pedicellate, evanescent. Ascospores oblong to ellipsoidal, smooth-walled or verrucose, hyaline when young, becoming brown, 1-septate, with large mucilaginous sheath or not. Asexual morph: Undetermined (adapted from Sivanesan 1974, Mugambi \& Huhndorf 2010).

Notes - Spinulosphaeria was placed in Coronophorales and typified by S. thaxteri in having turbinate ascomata covered by tooth-like spines, Quellkörper present and ellipsoidal ascospores without sheath (Sivanesan 1974). Subsequently, Mugambi \& Huhndorf (2010) introduced a second species, S. nuda, and analyzed its LSU sequence data. However, $S$. nuda is characterized by glabrous ascomata without Quellkörper and ellipsoidal ascospores with large glutinous sheath, which are different from $S$. thaxteri. Spinulosphaeria is accepted as a member of Chaetosphaerellaceae based on molecular information of S. nuda (Maharachchikumbura et al. 2015, 2016, Hyde et al. 2017). In this study, Spinulosphaeria is basal to Chaetosphaerella and Crassochaeta in Chaetosphaerellaceae (0.92BY, Fig. 1).

Type species - Spinulosphaeria thaxteri (Pat.) Sivan., Trans. Br. mycol. Soc. 62(1): 36 (1974)Fig 12 Basionym - Neopeckia thaxteri Pat., Bull. Soc. mycol. Fr. 38(2): 83 (1922)

Facesoffungi number: FoF 10060

Saprobic on decayed wood. Sexual morph: Subiculum extensive, composed of densely clustered, brown to dark brown, septate, branched hyphae. Ascomata 860-910 $\times 230-440 \mu \mathrm{m}(\bar{x}=$ $885 \times 280 \mu \mathrm{m}, \mathrm{n}=5$ ), superficial, scattered to gregarious, black, with metallic iridescence, carbonaceous, turbinate, conical to ovoidal, tuberculate, collapsing when dry, surrounded with black, short, tooth-like, 1-4 furcate spines, lacking ostioles, with thin Quellkörper composed of elongated cells at the inner wall of apical region. Peridium 30-70 $\mu \mathrm{m}$ wide, outer layer composed of carbonaceous, dark tissues; middle layer composed of membranaceous, brown to hyaline cells of textura angularis; inner layer composed of hyaline cells of textura prismatica. Paraphyses septate, longer than asci, filiform, evanescent. Asci (30-)45-50(-68) $\times(8-) 10-13(-15) \mu \mathrm{m}(\bar{x}=48 \times 12$ $\mu \mathrm{m}, \mathrm{n}=20)$ at ascospore-bearing part, 8 -spored, unitunicate, clavate, apical ring, long pedicellate, evanescent. Ascospores $9.5-13 \times 3.5-5.5 \mu \mathrm{m}(\bar{x}=11 \times 4.5 \mu \mathrm{m}, \mathrm{n}=30)$, oblong to ellipsoidal, 
smooth-walled, hyaline, aseptate when young, becoming brown to olivaceous, 1-septate, guttulate. Asexual morph: Undetermined (adapted from Sivanesan 1974).

Material examined - USA, Florida, Dayton, on decayed wood, January 1898, R. Thaxter (FH-16-10965, holotype).

Known hosts and distribution - on decayed wood in Liberia, Sierra Leone, the USA (type locality).

Notes - Spinulosphaeria thaxteri was introduced based on Neopeckia thaxteri from the USA and is characterized by subiculum composed of branched hyphae, ascomata surrounded by special tooth-like spines and with thin Quellkörper. There is no molecular data available for this species. In this study, we re-examined the holotype and found that its ascomata are brittle; paraphyses and asci are evanescent.
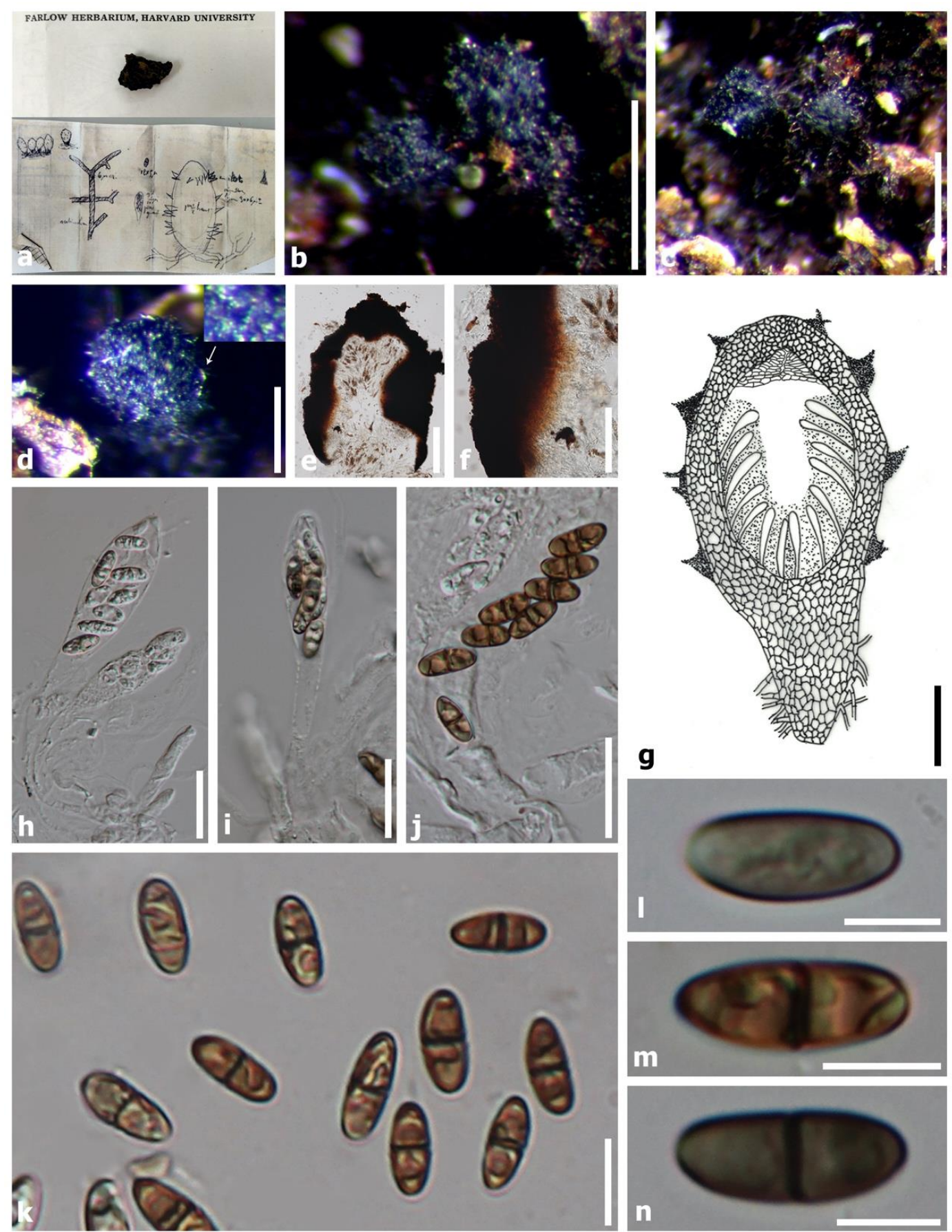

Figure 12 - Spinulosphaeria thaxteri: a-f, h-n (FH-16-10965, holotype); g (redrawn from Sivanesan 1974). a Material label. b-c Turbinate ascomata on wood. d Tuberculate ascoma (arrow 
indicates the enlarged tooth-like spine). e Ascoma cross section. f Peridium. g Sectional view of ascoma with spines. $\mathrm{h}-\mathrm{j}$ Asci. $\mathrm{k}-\mathrm{n}$ Ascospores. Scale bars: $\mathrm{b}-\mathrm{c}=500 \mu \mathrm{m}, \mathrm{d}-\mathrm{e}, \mathrm{g}=200 \mu \mathrm{m}, \mathrm{f}=100$ $\mu \mathrm{m}, \mathrm{h}-\mathrm{j}=20 \mu \mathrm{m}, \mathrm{k}=10 \mu \mathrm{m}, \mathrm{l}-\mathrm{n}=5 \mu \mathrm{m}$.

Coronophoraceae Höhn., Sber. Akad. Wiss. Wien, Math.-naturw. Kl., Abt. 1 116: 624 (1907)

Saprobic on wood, sometimes fungicolous. Sexual morph: Ascomata perithecial or without an external opening, solitary or gregarious, semi-immersed or erumpent or superficial, black, usually carbonaceous, globose to subglobose, sometimes with necks, tuberculate, collapsing or laterally collapsing when dry, glabrous or with hairs, with or lacking ostioles, usually with a central column of mucilaginous cells (Quellkörper). Peridium outer layer composed of carbonaceous, black tissue; inner layer composed of membranaceous, brown to hyaline cells of textura angularis to textura prismatica. Paraphyses absent or numerous, filiform, septate, evanescent. Asci numerous or rare, polysporous, unitunicate, clavate to cylindrical, long pedicellate, apex blunt or rounded, apical ring inconspicuous, evanescent. Ascospores crowded, numerous, hyaline, allantoid to cylindrical, sometimes curved, 0-1-septate, smooth-walled, mostly with guttules. Asexual morph: Undetermined (adapted from Fuckel 1864, Saccardo 1882a).

Type genus - Coronophora Fuckel

Notes - Coronophoraceae was introduced by von Höhnel (1907) to accommodate Cryptosphaerella and Coronophora, and it is characterized by polysporous asci and hyaline, allantoid ascospores. Subsequently, Cryptosphaerella was clarified as a genus in Scortechiniaceae based on phylogenetic result (Mugambi \& Huhndorf 2010). Coronophora was placed as an independent clade in Coronophorales based on the sequences data of Cor. gregaria (Mugambi \& Huhndorf 2010). Therefore, Coronophora is the only member in Coronophoraceae, and this genus is similar to Fracchiaea (Nitschkiaceae) and Pleurostoma (Pleurostomataceae, Calosphaeriales) in having black ascomata and clavate, polysporous asci (Petch 1916, Barr 1985, Mugambi \& Huhndorf 2010, Maharachchikumbura et al. 2015, 2016, Hyde et al. 2020e).

Coronophora Fuckel, Fungi rhenani exsic., fasc. 10: no. 961 (1864)

Saprobic on wood, sometimes fungicolous. Sexual morph: Ascomata perithecial or without an external opening, solitary or gregarious, semi-immersed or erumpent or superficial, black, usually carbonaceous, globose to subglobose, sometimes with necks, tuberculate, collapsing or laterally collapsing when dry, glabrous or with hairs, with or lacking ostioles, usually with Quellkörper. Peridium usually outer layer composed of carbonaceous, black tissue; inner layer composed of membranaceous, brown to hyaline cells of textura angularis to textura prismatica. Paraphyses absent or numerous, filiform, septate, evanescent. Asci numerous or rare, polysporous, unitunicate, clavate to cylindrical, long pedicellate, apex blunt or rounded, apical ring inconspicuous, evanescent. Ascospores crowded, numerous, hyaline, allantoid to cylindrical, sometimes curved, 0-1-septate, smooth-walled, mostly with guttules. Asexual morph: Undetermined (adapted from Fuckel 1864, Saccardo 1882a).

Notes - Coronophora is typified by C. gregaria which has polysporous asci and hyaline, cylindrical, aseptate ascospores (Fuckel 1864, Saccardo 1882b). There are 27 species in this genus, two of which have available molecular data, C. gregaria and C. myricoides (Mugambi \& Huhndorf 2010, Hyde et al. 2016, Index Fungorum 2021). The characteristics of these two species are similar except for the ascospore size (Hyde et al. 2016). In this study, C. gregaria is sister to Scortechiniaceae $(100 \% \mathrm{ML} / 1.00 \mathrm{BY})$, whereas $C$. myricoides is sister to Fracchiaea (100\%ML/1.00BY) in Nitschkiaceae (Fig. 1). Thus, we transferred C. myricoides as Fracchiaea species (see notes for Fracchiaea myricoides).

Coronophora gregaria Fuckel, Jb. nassau. Ver. Naturk. 23-24: 229 (1870) [1869-70]

Fig. 13

Basionym - Sphaeria gregaria Lib., Pl. crypt. Arduenna, fasc. (Liège) 2(nos 101-200): no. $145(1832)$ 
Facesoffungi number: FoF 01119

Saprobic on wood. Sexual morph: Ascomata $0.9-1.4 \times 0.3-1.2 \mathrm{~mm}(\bar{x}=1.2 \times 0.6 \mathrm{~mm}, \mathrm{n}=$ 10 ), gregarious in oval groups, in valsoid configuration with necks converging, immersed to erumpent through the bark of host, black, carbonaceous, oblong to subglobose, tuberculate, laterally collapsing when dry, glabrous, lacking ostioles, with a central column of hyaline, mucilaginous cells (Quellkörper). Peridium 70-170 $\mu \mathrm{m}$ wide, comprising three layers, outer layer composed of carbonaceous, black tissue, 14-95 $\mu \mathrm{m}$ wide; middle layer composed of membranaceous, dark brown to brown cells of textura angularis, 30-85 $\mu \mathrm{m}$ wide, Munk pores rarely present; inner layer composed of membranaceous, hyaline cells of textura prismatica, 12-40 $\mu \mathrm{m}$ wide. Paraphyses absent. Asci (57-)75-90(-120) $\times(10-) 12-15(-20) \mu \mathrm{m}(\bar{x}=85 \times 13.5 \mu \mathrm{m}, \mathrm{n}$ $=30$ ), numerous, polysporous, unitunicate, clavate, long pedicellate, apex rounded, apical ring inconspicuous. Ascospores (5.5-)7-8(-9.5) $\times 1.2-2.5 \mu \mathrm{m}(\bar{x}=7.5 \times 1.8 \mu \mathrm{m}, \mathrm{n}=50)$, crowded, numerous, hyaline, allantoid to cylindrical, slightly curved, aseptate, smooth-walled, with rare guttules. Asexual morph: Undetermined (adapted from Saccardo 1882a).
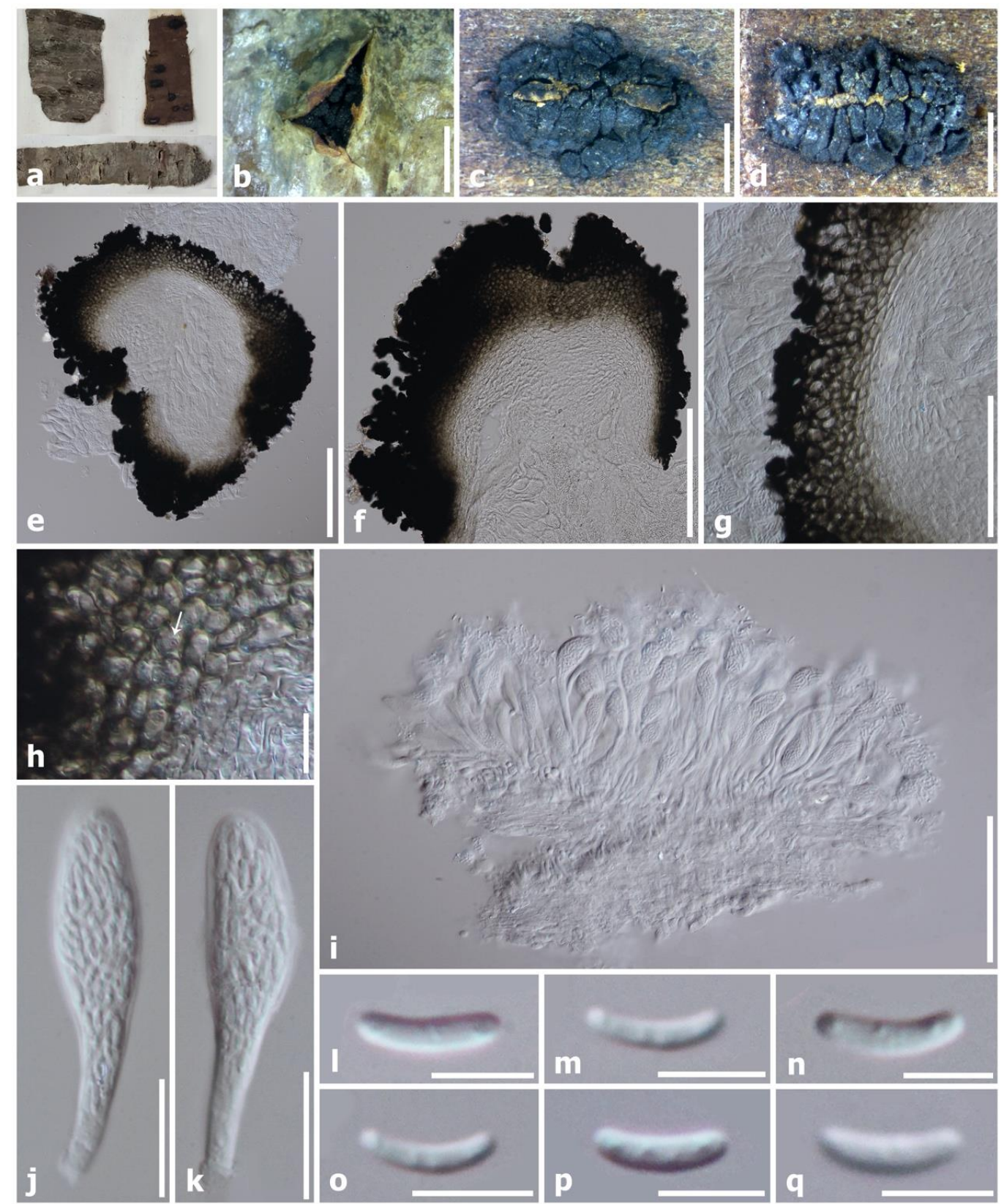

Figure 13 - Coronophora gregaria: (BR-BR5020094489111, isotype). a Material. b Ascomata erumpent through the bark of host. c-d Ascomata on decorticated wood. e Ascoma cross section. 
f Quellkörper. g Peridium. h Munk pore. i-k Asci. 1-q Ascospores. Scale bars: $b-d=2 \mathrm{~mm}$, $\mathrm{e}-\mathrm{f}=200 \mu \mathrm{m}, \mathrm{g}, \mathrm{i}=100 \mu \mathrm{m}, \mathrm{h}, \mathrm{j}-\mathrm{k}=20 \mu \mathrm{m}, \mathrm{l}-\mathrm{q}=5 \mu \mathrm{m}$.

Material examined - Belgium, on decayed wood of Prunus cerasus or Sorbus aucuparia, Autumn, M.A. Libert (BR-BR5020094489111, isotype).

Known hosts and distribution - on decayed branch of Betula, Prunus, Sorbus and Tilia in Belgium (type locality), France, Germany and Italy (Saccardo 1882b).

Notes - Coronophora gregaria was initially introduced as Sphaeria gregaria Lib. from Belgium. Mugambi \& Huhndorf (2010) placed this species in Coronophoraceae based on TEF and RPB2 sequences data. Morphologically, Coronophora was reported to be similar to Fracchiaea and Pleurostoma (Petch 1916, Barr 1985). We re-examined the isotype and found that it has gregarious ascomata in oval groups as valsoid configuration with necks converging, Quellkörper present and polysporous asci with inconspicuous discharge mechanism (ascospores accumulate on the ascus apex, causing the ascus to expand to rupture and release ascospores, Fig. 13i). These characteristics are different from Fracchiaea and Pleurostoma. The strain of C. gregaria (ANM1555) is basal to Scortechiniaceae in Coronophorales (100\%ML/1.00BY, Fig. 1).

Nitschkiaceae Nannf., Nova Acta R. Soc. Scient. upsal., Ser. 4 8(no. 2): 56 (1932)

Saprobic or parasitic on wood, leaves or lichen. Sexual morph: Subiculum absent or composed of numerous or rare, brown, branched, septate hyphae. Ascomata perithecial or without an external opening, solitary or gregarious, semi-immersed or erumpent or superficial, sitting on or in a subiculum, usually carbonaceous, brown to black, cupuliform, globose to subglobose, glabrous or with spines, the apex collapsing when dry or shallowly cupulate when moist, with periphyses inside of the ostioles or inconspicuous ostioles or lacking ostioles, with or Quellkörper absent. Peridium usually outer layer composed of carbonaceous, black tissue; inner layer composed of membranaceous, brown to hyaline cells of textura angularis to textura prismatica, sometimes Munk pores present. Paraphyses absent or numerous, filiform, branched or unbranched, septate, evanescent. Asci 4-, 8- or multi-spored, unitunicate, clavate to cylindrical, pedicellate or sessile, apex blunt or rounded, apical ring inconspicuous, evanescent. Ascospores hyaline to brown, allantoid, ellipsoidal to cylindrical, sometimes curved, smooth-walled, sometimes with mucilaginous sheath or appendages, mostly with guttules. Asexual morph: Undetermined (adapted from Subramanian \& Sekar 1990, Hyde et al. 2020e).

Type genus - Nitschkia G.H. Otth ex P. Karst.

Notes - Nitschkiaceae was initially introduced as subfamily 'Nitschkieae', which has affinity with morphology of Coronophoraceae (Fitzpatrick 1923). Nannfeldt (1932) clarified their relationship and established Nitschkiaceae in Coronophorales. Subsequently, this family accommodated 14 genera and, is characterized by black, turbinate, cupuliform ascomata, usually with Quellkörper and clavate to subcylindrical asci (Nannfeldt 1932, 1975, Subramanian \& Sekar 1990, Maharachchikumbura et al. 2016, Hyde et al. 2020e). Four genera, Acanthonitschkea, Fracchiaea, Neotrotteria and Nitschkia, have sequences data (Huhndorf et al. 2004b, Mugambi \& Huhndorf 2010). We found that Acanthonitschkea, Fracchiaea and Nitschkia (except $N$. pezizoidea) are well clustered in Nitschkiaceae (96\%ML/1.00BY) and closely related to Bertiaceae, but Neotrotteria nests in Ceratostomataceae $(68 \% \mathrm{ML}$, Fig. 1). We place Neotrotteria in Ceratostomataceae based on our phylogenetic result (see notes for Neotrotteria).

Acanthonitschkea Speg., Anal. Mus. nac. B. Aires, Ser. 3 17(10): 116 (1908)

Saprobic on wood or lichen. Sexual morph: Subiculum composed of numerous, brown to black, branched, septate, sinuous hyphae with metallic iridescence; or rigid, straight or slightly sinuous, unbranched, aseptate, brown to black spines with metallic iridescence form a dense barricade. Ascomata perithecial or without an external opening, scattered or gregarious, semiimmersed or erumpent or superficial, sitting on or in a subiculum, carbonaceous, coriaceous or membranaceous, brown to black, turbinate, cupuliform to subglobose, tuberculate, with spines 
similar to those on the mycelium, the apex collapsing, with periphyses inside of the inconspicuous ostioles or lacking ostioles, with or Quellkörper absent. Peridium outer layer composed of carbonaceous, black tissue; inner layer composed of membranaceous, brown to hyaline cells of textura angularis to textura prismatica, sometimes Munk pores present. Paraphyses absent. Asci 8spored, unitunicate, clavate, apex blunt or rounded, apical ring inconspicuous, with long pedicel, evanescent. Ascospores bi-seriate to overlapping, hyaline, 0-1-septate, ellipsoidal to cylindrical, sometimes curved, smooth-walled, mostly with guttules. Asexual morph: Undetermined (adapted from Fitzpatrick 1923).

Notes - Acanthonitschkea was introduced as a genus with characteristics similar to Nitschkia, but with spiny ascomata (Spegazzini 1908, Fitzpatrick 1923). This genus includes 10 species and is typified by $A$. argentinensis in having spiny, tuberculate ascomata, clavate asci and allantoid ascospores (Fitzpatrick 1923, Index Fungorum 2021). Two species have available molecular data, A. argentinensis and A. tristis (Mugambi \& Huhndorf 2010). In this study, these two Acanthonitschkea species are sister to Nitschkia calyculus, $N$. grevillii and $N$. tetraspora (73\% ML/0.95BY, Fig. 1).

Acanthonitschkea argentinensis Speg., Anal. Mus. nac. B. Aires, Ser. 3 17(10): 116 (1908)

Facesoffungi number: FoF 10157

Fig. $14 \mathrm{p}$

Saprobic on wood. Sexual morph: Subiculum composed of sparse to numerous, brown to black, branched, septate, sinuous hyphae with metallic iridescence; or erect, rigid, straight or slightly sinuous, unbranched, aseptate, brown to black spines with metallic iridescence form a dense barricade. Ascomata scattered or densely gregarious, superficial, sitting on a subiculum, membranaceous to coriaceous, brown to black, turbinate, cupuliform, tuberculate, with spines similar to those on the mycelium, the apex collapsing to deeply cupulate, lacking ostioles. Peridium composed of brown to hyaline cells of textura angularis to textura prismatica, Munk pores present. Paraphyses absent. Asci 8-spored, unitunicate, clavate, apex blunt or rounded, apical ring inconspicuous, with long pedicel, evanescent. Ascospores bi-seriate to overlapping, hyaline, 1septate, allantoid to horseshoe-shaped, smooth-walled, with two guttules in each cell. Asexual morph: Undetermined (adapted from Fitzpatrick 1923, Subramanian \& Sekar 1990).

Known hosts and distribution - on decayed wood in Argentina (type locality), India and Puerto Rico (Spegazzini 1908, Subramanian \& Sekar 1990, Mugambi \& Huhndorf 2010).

Notes - Acanthonitschkea argentinensis was collected from a decayed wood in Argentina in February (Spegazzini 1908). This species was considered to have affinity with Nitschkia based on similar morphology (Fitzpatrick 1923, Subramanian \& Sekar 1990). A. argentinensis (SMH1395) was sequenced and shown to be related to Nitschkia species based on LSU, TEF and RPB2 sequence analyses (Mugambi \& Huhndorf 2010). In this study, A. argentinensis is sister to A. tristis (99\% ML/1.00BY, Fig. 1) in Nitschkiaceae.

Acanthonitschkea tristis (J. Kickx f.) Nannf., Svensk bot. Tidskr. 69(1): 57 (1975) Fig. 14a-o Basionym - Hyphasma triste J. Kickx f., FI. crypt. Louvain (Bruxelles): 118 (1835)

Facesoffungi number: FoF 10061

Saprobic on wood. Sexual morph: Subiculum composed of numerous, brown to black, branched, septate, sinuous hyphae, 4-7 $\mu \mathrm{m}$ wide, with metallic iridescence. Ascomata 380-600 $\times$ 375-460 $\mu \mathrm{m}(\bar{x}=478 \times 420 \mu \mathrm{m}, \mathrm{n}=10)$, scattered or densely gregarious, superficial on bark or decorticated wood, sometimes erumpent through the bark of substrate, sitting in a subiculum, carbonaceous, black, turbinate, cupuliform, tuberculate, lacking ostioles, with Quellkörper. Peridium 26-80 $\mu \mathrm{m}$ wide, comprising three layers, outer layer composed of carbonaceous, black tissue; middle layer composed of membranaceous, dark brown to brown cells of textura angularis, Munk pores present; inner layer composed of membranaceous, hyaline cells of textura prismatica. Paraphyses absent. Asci 8-spored, unitunicate, clavate, with a blunt, thick apex and long pedicel, evanescent. Ascospores 5.5-8(-10) $\times 1.5-2.5 \mu \mathrm{m}(\bar{x}=6.5 \times 2 \mu \mathrm{m}, \mathrm{n}=50)$, bi-seriate to 
overlapping, hyaline, ellipsoidal to fusiform, straight, aseptate when young, becoming 1-septate, smooth-walled, with guttules. Asexual morph: Undetermined (adapted from Nannfeldt 1975, Subramanian \& Sekar 1990).
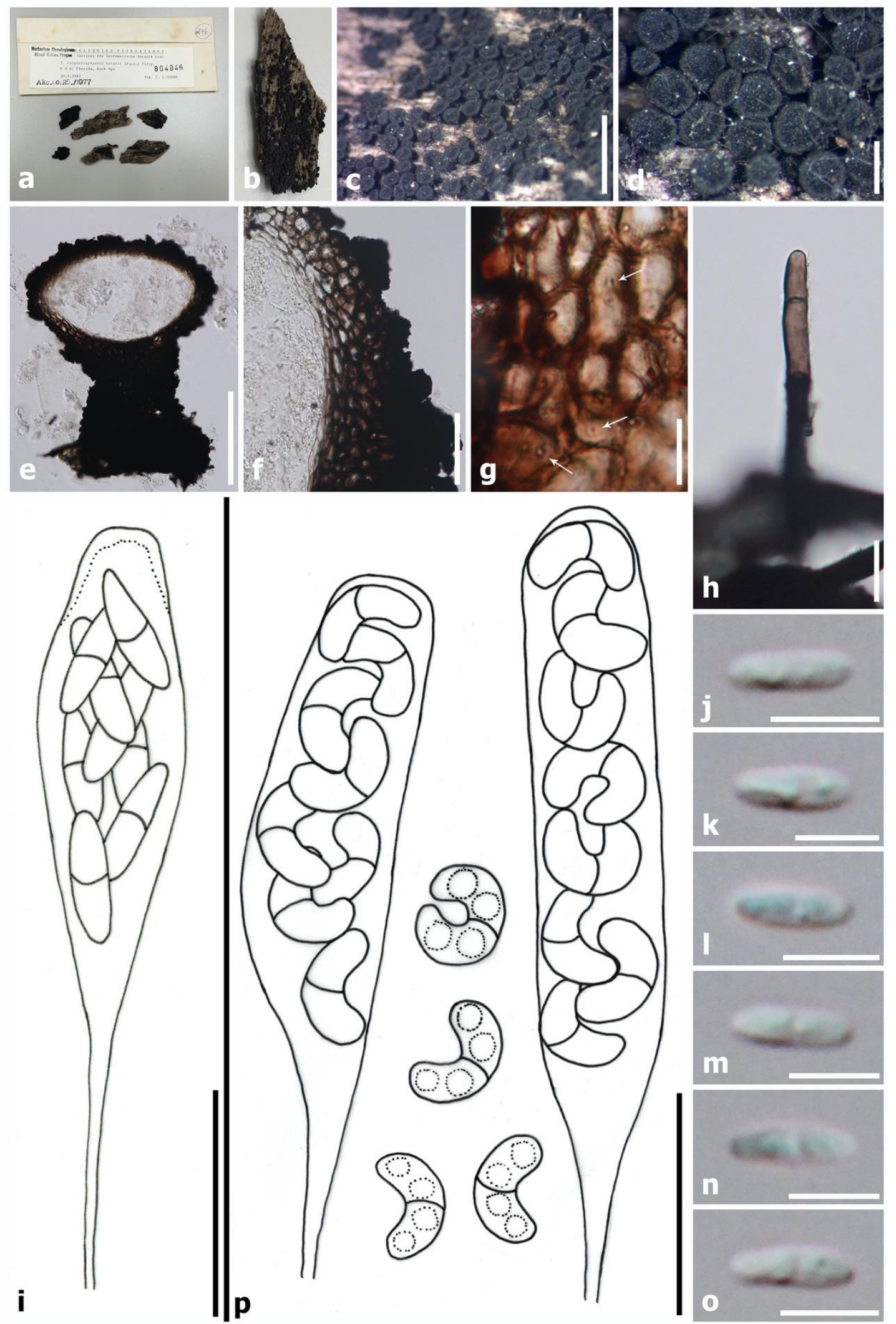

Figure 14 - Acanthonitschkea tristis: a-o (PRM-804846). a Material label. b Gregarious ascomata on decorticated wood. c-d Ascomata. e Ascoma cross section. f Peridium. g Munk pores (arrow). $\mathrm{h}$ Septate hyphae. i Asci with thick apex. j-o Ascospores; Acanthonitschkea argentinensis: 
$\mathrm{p}$ (redrawn from Subramanian \& Sekar 1990). p Asci and ascospores. Scale bars: $\mathrm{c}=2 \mathrm{~mm}, \mathrm{~d}=$ $500 \mu \mathrm{m}, \mathrm{e}=200 \mu \mathrm{m}, \mathrm{f}=50 \mu \mathrm{m}, \mathrm{h}=20 \mu \mathrm{m}, \mathrm{g}, \mathrm{i}, \mathrm{p}=10 \mu \mathrm{m}, \mathrm{j}-\mathrm{o}=5 \mu \mathrm{m}$.

Material examined - USA, Florida, Rock Spa, on decayed, decorticated wood, 20 March 1942, C.L. Shear (PRM-804846).

Known hosts and distribution - on decayed wood in the USA (type locality) and Ecuador (Fitzpatrick 1923, Mugambi \& Huhndorf 2010).

Notes - Nannfeldt (1975) clarified materials related to 'Sphaeria tristis' and introduced Acanthonitschkea tristis. Afterwards, A. tristis (SMH4723) from Ecuador was sequenced and it nested in Nitschkiaceae (Mugambi \& Huhndorf 2010). In this study, A. tristis is sister to A. argentinensis (99\%ML/1.00BY, Fig. 1) in Nitschkiaceae based on multi-gene analysis.

Biciliosporina Subram. \& Sekar, Kavaka 18(1-2): 69 (1993) [1990]

Saprobic on wood. Sexual morph: Ascomata solitary to gregarious, immersed to erumpent thought the bark of substrate, coriaceous, globose to subglobose, black, with metallic iridescence, the apex collapsing when dry, lacking ostioles, with Quellkörper. Peridium composed of brown to hyaline cells of textura angularis to textura prismatica, Munk pores present. Paraphyses absent. Asci 8 -spored, arising from a hyaline placenta-like tissue, radially extending into the locule around the Quellkörper from the base, unitunicate, clavate to cylindrical, apex rounded, apical ring inconspicuous, with long pedicel, evanescent. Ascospores uni- or bi-seriate, hyaline, aseptate, ellipsoidal to reniform, smooth-walled, with a filiform, flagella-like appendage at each end, guttulate. Asexual morph: Undetermined (adapted from Subramanian \& Sekar 1990).

Notes - The monotypic Biciliosporina was introduced as a genus in Coronophoraceae and typified by $B$. karwarensis in having subglobose ascomata, clavate to cylindrical asci and reniform ascospores with a flagella-like appendage at each end (Subramanian \& Sekar 1990). Later, this genus was clarified as a member of Nitschkiaceae based on morphology (Eriksson \& Hawksworth 1987, Lumbsch \& Huhndorf 2010, Maharachchikumbura et al. 2016, Hyde et al. 2020e, Index Fungorum 2021). We found that the ascospores of Biciliosporina are similar to Janannfeldtia, although the latter has polysporous asci.

Biciliosporina karwarensis Subram. \& Sekar, Kavaka 18(1-2): 69 (1993) [1990]Ｆig. 15a-e Facesoffungi number: FoF 10158

Saprobic on wood. Sexual morph: Ascomata solitary to gregarious, immersed to erumpent thought the bark of substrate, coriaceous, globose to subglobose, black, with metallic iridescence, the apex collapsing when dry, lacking ostioles, with Quellkörper. Peridium composed of brown to hyaline cells of textura angularis to textura prismatica, Munk pores present. Paraphyses absent. Asci 8-spored, arising from a hyaline placenta-like tissue, radially extending into the locule around the Quellkörper from the base, unitunicate, clavate to cylindrical, apex rounded, apical ring inconspicuous, with long pedicel, evanescent. Ascospores uni- or bi-seriate, hyaline, aseptate, ellipsoidal to reniform, smooth-walled, with a filiform, flagella-like appendage at each end, guttulate. Asexual morph: Undetermined (adapted from Subramanian \& Sekar 1990).

Material examined - India, Karnataka, Karwar, upper Anmod, on dead twig, 22 November 1980, G. Sekar (IMI-324681, holotype).

Known hosts and distribution - on decayed wood in India (type locality) (Subramanian \& Sekar 1990).

Notes - Biciliosporina karwarensis was introduced based on the specimen IMI324681 (Subramanian \& Sekar 1990). We re-examined this sample and found that most of the ascomata were shrivelled and collapsed, and no other structures could be found.

Botryola Bat. \& J.L. Bezerra, in Batista et al., Publicações Inst. Micol. Recife 431: 11 (1964)

Saprobic on wood. Sexual morph: Ascomata solitary to gregarious, immersed to erumpent thought the bark of substrate, carbonaceous, cupuliform, globose to subglobose, black, with spinous 
setae, lacking ostioles, with Quellkörper. Peridium composed of brown to hyaline cells of textura angularis to textura prismatica. Paraphyses absent. Asci 4-spored, unitunicate, clavate to cylindrical, apex rounded, with long pedicel, evanescent. Ascospores uni- or bi-seriate, hyaline, 1septate, oblong to cylindrical, smooth-walled, guttulate. Asexual morph: Undetermined (adapted from Batista et al. 1964).

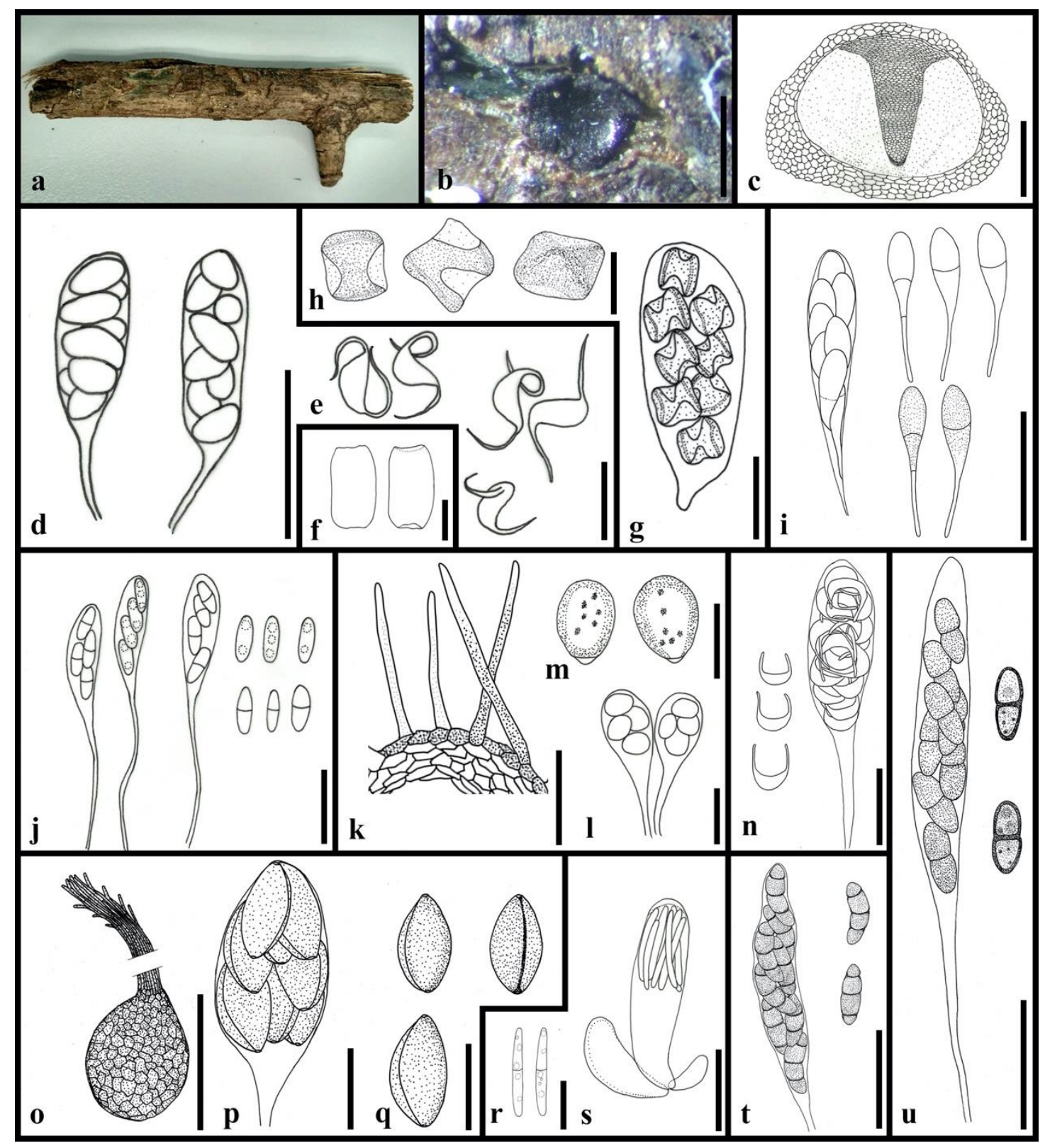

Figure 15 - Biciliosporina karwarensis: a-b (IMI-IMI324681, holotype); c-e (redrawn from Subramanian \& Sekar 1990). a Material. b Collapsed ascomata on the host. c Sectional view of ascoma. d Asci. e Ascospores; Syspastospora parasitica: f (redrawn from Cannon \& Hawksworth 1982). f Ascospores; Scopinella barbata: g-h (redrawn from Hawksworth 1975). g Ascus. h Ascospores; Loranitschkia viticola: i (redrawn from Vasilyeva et al. 2010). i Asci and ascospores; Botryola tetrasperma: j (redrawn from Batista et al. 1964). j Asci and ascospores; Setiferotheca nipponica: $\mathrm{k}-\mathrm{m}$ (redrawn from Matsushima 1995). $\mathrm{k}$ Peridium with setae. 1 Asci. $\mathrm{m}$ Ascospores; Janannfeldtia karwarensis: n (redrawn from Subramanian \& Sekar 1990). n Asci and ascospores; Vittatispora coorgii: o-q (redrawn from Chaudhary et al. 2006). o Ascoma. p Ascus. q Ascospores; Rhagadostomella gregaria: $\mathrm{r}-\mathrm{s}$ (redrawn from Etayo 2002). $\mathrm{r}$ Ascospores. $\mathrm{s}$ Asci; Neochaetosphaerella thaxteriospora: $\mathrm{t}$ (redrawn from Vasilyeva et al. 2012). $\mathrm{t}$ Ascus and ascospores; Tortulomyces thailandicus: u (redrawn from Vasilyeva et al. 2013). u Ascus and 
ascospores. Scale bars: $\mathrm{b}=500 \mu \mathrm{m}, \mathrm{c}, \mathrm{k}, \mathrm{o}=200 \mu \mathrm{m}, \mathrm{i}=50 \mu \mathrm{m}, \mathrm{d}, \mathrm{j}, \mathrm{n}, \mathrm{s}-\mathrm{u}=20 \mu \mathrm{m}, \mathrm{e}, \mathrm{g}, 1, \mathrm{r}=10$ $\mu \mathrm{m}, \mathrm{h}, \mathrm{m}, \mathrm{p}-\mathrm{q}=5 \mu \mathrm{m}, \mathrm{f}=2 \mu \mathrm{m}$.

Notes - The monotypic Botryola was initially placed in Coronophoraceae, but was subsequently clarified as a genus in Nitschkiaceae based on its ascomata similar to Fracchiaea (Batista et al. 1964, Eriksson \& Hawksworth 1987, Lumbsch \& Huhndorf 2010, Maharachchikumbura et al. 2016, Hyde et al. 2020e).

Botryola tetrasperma Bat. \& J.L. Bezerra, in Batista, Bezerra, Castrillón \& Matta, Publicações Inst. Micol. Recife 431: 13 (1964)

Fig. $15 \mathrm{j}$

Facesoffungi number: FoF 10159

Saprobic on wood. Sexual morph: Ascomata solitary to gregarious, immersed to erumpent thought the bark of substrate, carbonaceous, cupuliform, globose to subglobose, black, with spinous setae, lacking ostioles, with Quellkörper. Peridium composed of brown to hyaline cells of textura angularis to textura prismatica. Paraphyses absent. Asci 4-spored, unitunicate, clavate to cylindrical, apex rounded, with long pedicel, evanescent. Ascospores uni- to bi-seriate, hyaline, 1septate, oblong to cylindrical, smooth-walled, guttulate. Asexual morph: Undetermined (adapted from Batista et al. 1964).

Known hosts and distribution - on decayed wood in Brazil (type locality) (Batista et al. 1964).

Notes - Botryola tetrasperma was collected from Manaus, Brazil on 20 February 1961 (Batista et al. 1964). We found that it is similar to Setiferotheca which has spiny ascomata and 4spored asci, although the latter has perithecial ascomata without Quellkörper.

Fracchiaea Sacc., Atti Soc. Veneto-Trent. Sci. Nat. 2(1): 163 (1873)

Saprobic on wood. Sexual morph: Ascomata scattered to gregarious, immersed to erumpent through the bark of substrate or superficial, carbonaceous to coriaceous, black, turbinate, globose to subglobose, with brown to black, spinous setae, lacking ostioles, sometimes with a small papillate ostiole-like structure without an external opening, with Quellkörper incipient. Peridium composed of brown to hyaline cells of textura angularis to textura prismatica, Munk pores present. Paraphyses absent. Asci polysporous, unitunicate, clavate to cylindrical, pedicellate or sessile, apex rounded, apical ring inconspicuous, evanescent. Ascospores arranged obliquely in the ascus in several longitudinal rows, hyaline to yellowish, allantoid, ellipsoidal to cylindrical, slightly curved, 0-1-septate, smooth-walled, mostly with guttules. Asexual morph: Undetermined (adapted from Fitzpatrick 1924, Subramanian \& Sekar 1990).

Notes - Fracchiaea is typified by $F$. heterogenea and was clarified as a genus in Nitschkiaceae based on ascomata with Quellkörper (Fitzpatrick 1924, Subramanian \& Sekar 1990). Subsequently, $F$. broomeana and $F$. lunata were sequenced and these strains nested in Nitschkiaceae (Huhndorf et al. 2004b, Mugambi \& Huhndorf 2010). In this study, Fracchiaea is basal to the clade of Acanthonitschkea and Nitschkia (96\%ML/1.00BY, Fig. 1). Coronophora myricoides is transferred as $F$. myricoides based on morphology and phylogenetic result (see notes for $F$. myricoides).

Fracchiaea heterogenea Sacc., Atti Soc. Veneto-Trent. Sci. Nat. 2(1): 163 (1873)

Fig. 16

Facesoffungi number: FoF 10062

Saprobic on wood. Sexual morph: Subiculum composed of numerous, brown to black, branched, septate, sinuous hyphae, 4-8 $\mu \mathrm{m}$ wide. Ascomata 350-600 $\mu \mathrm{m}(\bar{x}=470 \mu \mathrm{m}, \mathrm{n}=5)$ diam., scattered to densely gregarious, immersed to erumpent through the bark of substrate or superficial, sitting on a subiculum, carbonaceous, black, turbinate, globose to subglobose, the apex collapsing when dry, tuberculate, surrounded by dark brown to black, tiny spines 13-22 $\mu \mathrm{m}$ high, with a small papillate ostiole-like structure without an external opening, with Quellkörper incipient. Peridium 36-95 $\mu \mathrm{m}$ wide, comprising three layers, outer layer composed of carbonaceous, black 
tissue; middle layer composed of membranaceous, dark brown to brown cells of textura angularis, rare Munk pore present; inner layer membranaceous, composed of hyaline cells of textura prismatica. Paraphyses absent. Asci (73-)85-90(-100) $\times 10-15(-20) \mu \mathrm{m}(\bar{x}=87 \times 12 \mu \mathrm{m}, \mathrm{n}=20)$, polysporous, unitunicate, clavate to cylindrical, apex rounded, apical ring inconspicuous, with a short pedicel, evanescent. Ascospores $8-12 \times 1.5-2.5 \mu \mathrm{m}(\bar{x}=9.5 \times 2 \mu \mathrm{m}, \mathrm{n}=50)$, arranged obliquely in the ascus in several longitudinal rows, hyaline, allantoid to cylindrical, slightly curved, aseptate, rarely 1-septate, smooth-walled, guttulate. Asexual morph: Undetermined (adapted from Fitzpatrick 1924, Subramanian \& Sekar 1990).

Material examined - Italy, Veneto, Treviso, on decayed branch of Aesculus, Corylus, Rhamnus etc., 1873, P.A. Saccardo (UPS-UPS:BOT:F-736393, isotype).

Known hosts and distribution - on decayed wood of Aesculus, Alnus, Buxus, Corylus, Eucalyptus, Lonicera, Morus, Myrica, Pinus, Quercus, Rhamnus, Rubus etc. in Brazil, France, Italy (type locality), India, the USA (Saccardo 1873a, Fitzpatrick 1924, Subramanian \& Sekar 1990).

Notes - Fracchiaea heterogenea was introduced by Saccardo (1873b) from Italy and is characterized by tuberculate ascomata, polysporous asci and allantoid ascospores (Saccardo 1873a, Fitzpatrick 1924, Subramanian \& Sekar 1990). Specimen F-736393 collected by Saccardo from Italy, in 1873 is consistent with the specimen information described by Saccardo (1837a, b). Therefore, we state that UPS:BOT:F-736393 is isotype of F. heterogenea.

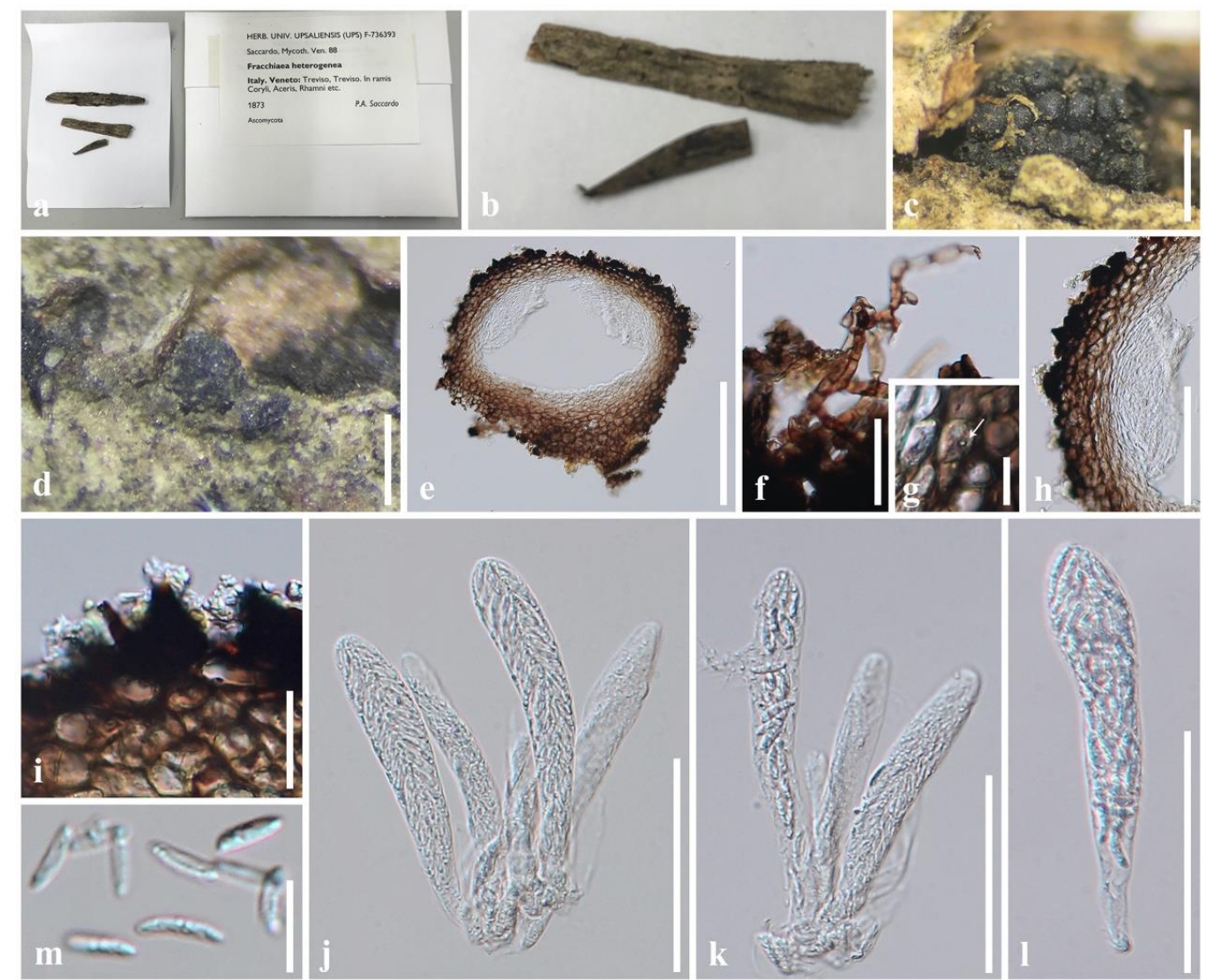

Figure 16 - Fracchiaea heterogenea: (UPS-UPS:BOT:F-736393, isotype). a Material label. b Material. c Gregarious ascomata. d Ascoma erumpent through the bark of host. e Ascoma cross section. f Septate hyphae. g Munk pores (arrow). h Peridium. i Spine on ascoma. j-1 Asci. $\mathrm{m}$ Ascospores. Scale bars: $\mathrm{c}-\mathrm{d}=500 \mu \mathrm{m}, \mathrm{e}=200 \mu \mathrm{m}, \mathrm{h}=100 \mu \mathrm{m}, \mathrm{f}, \mathrm{j}-\mathrm{l}=50 \mu \mathrm{m}, \mathrm{i}=20 \mu \mathrm{m}, \mathrm{g}, \mathrm{m}=$ $10 \mu \mathrm{m}$.

Fracchiaea myricoides (H.X. Wu \& K.D. Hyde) S.K. Huang \& K.D. Hyde, comb. nov.

Basionym - Coronophora myricoides H.X. Wu \& K.D. Hyde, in Hyde et al., Fungal Diversity 80: 164 (2016) 
Index Fungorum number: IF558200

Notes - Coronophora myricoides is characterized by tuberculate ascomata and polysporous asci, which are similar to the type species of Coronophora, C. gregaria (Hyde et al. 2016). Hyde et al. (2016) sequenced C. myricoides (IFRD 9201), but lacked discussion on its phylogenetic analysis. In this study, strain of C. myricoides (IFRD 9201) is sister to Fracchiaea (100\%ML/1.00BY) in Nitschkiaceae (Fig. 1). In addition, C. myricoides is also similar to Fracchiaea with tuberculate ascomata and polysporous asci. We therefore place $C$. myricoides in Fracchiaea based on morphology and phylogenetic result.

Groenhiella Jørg. Koch, E.B.G. Jones \& S.T. Moss, Bot. Mar. 26(6): 265 (1983)

Saprobic on wood. Sexual morph: Ascomata solitary to gregarious, superficial, sitting on rarely developed subiculum, carbonaceous to coriaceous, brown to black, reniform to subglobose, collapsing or laterally collapsing when dry, lacking ostioles. Peridium composed of brown to hyaline cells of textura angularis to textura prismatica. Pseudoparaphyses numerous, septate, constricted at the septa, unbranched or branched, evanescent. Asci 8-spored, unitunicate, arising from a hyaline placenta-like tissue, radially extending into the locule from the base, broadly clavate, with long pedicel, evanescent. Ascospores hyaline when young, becoming pale brown to brown, broadly fusiform to ellipsoidal, with papillate at each end, 1-septate, smooth-walled, guttulate. Appendages initially mucilaginous sheath-like and encapsulate the whole ascospore, becoming fragment to give rise at each end and middle septum. Asexual morph: Undetermined (adapted from Koch et al. 1983).

Notes - The monotypic Groenhiella was introduced as a lignicolous marine fungus and initially placed in Coronophoraceae (Koch et al. 1983). It is characterized by black ascomata, clavate asci and 1-septate ascospores with fragmented sheath (Koch et al. 1983). Later, this genus was transferred as a member of Nitschkiaceae (Eriksson \& Hawksworth 1987, Lumbsch \& Huhndorf 2010, Maharachchikumbura et al. 2016, Hyde et al. 2020e, Index Fungorum 2021).

Groenhiella bivestia Jørg. Koch, E.B.G. Jones \& S.T. Moss, Bot. Mar. 26(6): 265 (1983) Fig. 17 Facesoffungi number: FoF 10063

Saprobic on wood. Sexual morph: Ascomata solitary to gregarious, superficial, sitting on rarely developed subiculum, carbonaceous to coriaceous, brown to black, reniform to subglobose, collapsing or laterally collapsing when dry, lacking ostioles. Peridium 27-60 $\mu \mathrm{m}$ wide, composed of brown to hyaline cells of textura angularis to textura prismatica. Pseudoparaphyses numerous, septate, constricted at the septa, unbranched or branched, evanescent. Asci (25-)35-40 × 13-20 $\mu \mathrm{m}$ $(\bar{x}=38 \times 16 \mu \mathrm{m}, \mathrm{n}=10)$ at ascospore-bearing part, 8 -spored, unitunicate, arising from a hyaline placenta-like tissue, radially extending into the locule from the base, broadly clavate, with long pedicel, evanescent. Ascospores $12-15 \times 6-9 \mu \mathrm{m}(\bar{x}=14 \times 8 \mu \mathrm{m}, \mathrm{n}=30)$, hyaline when young, becoming pale brown to brown, broadly fusiform to ellipsoidal, with papillate at each end, 1septate, smooth-walled, guttulate. Appendages initially mucilaginous sheath-like and encapsulate the whole ascospore, becoming a fragment at each end and at middle septum. Asexual morph: Undetermined (adapted from Koch et al. 1983).

Material examined - Denmark, Grønhøj, west coast of Jutland, on strongly decayed drift wood deposited at base of white dune, partly buried in sand, 16 November 1975, J. Koch (NY1315723, microslide of holotype, from the holotype IMI260599 and the slides made by J.J. Kohlmeyer).

Known hosts and distribution - on decayed wood in Denmark (type locality) (Koch et al. 1983).

Notes - Groenhiella bivestia was introduced by Koch et al. (1983) from Denmark. We were unable to obtain the holotype IMI260599. Therefore, we examined the permanent slides of IMI260599 made by Kohlmeyer, which were deposited as a microslide of holotype, NY-1315723. 


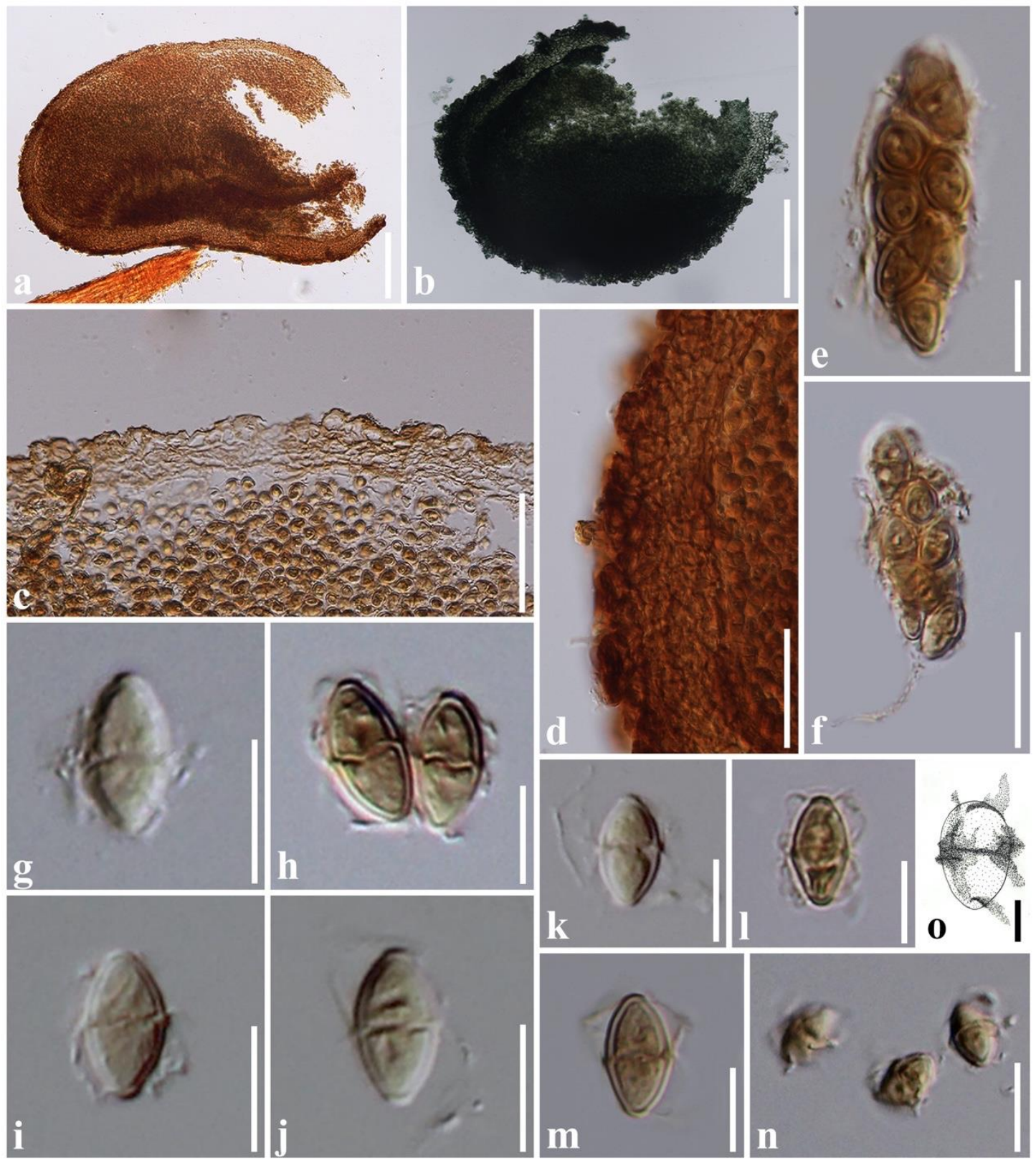

Figure 17 - Groenhiella bivestia: a-n (NY-1315723, microslide of holotype); o (redrawn from Koch et al. 1983). a-b Ascoma cross section (b in blue colouring agent). c-d Peridium. e-f Asci. $\mathrm{g}-\mathrm{o}$ Ascospores. Scale bars: $\mathrm{a}-\mathrm{b}=200 \mu \mathrm{m}, \mathrm{c}-\mathrm{d}=50 \mu \mathrm{m}, \mathrm{f}, \mathrm{n}=20 \mu \mathrm{m}, \mathrm{e}, \mathrm{g}-\mathrm{m}=10 \mu \mathrm{m}, \mathrm{o}=5 \mu \mathrm{m}$.

Janannfeldtia Subram. \& Sekar, Kavaka 18(1-2): 69 (1993) [1990]

Saprobic on wood. Sexual morph: Ascomata solitary to gregarious, immersed to erumpent thought the bark of substrate or superficial on decorticated wood, coriaceous to membranaceous, globose to subglobose, dark brown to black, the apex collapsing when dry, lacking ostioles, with Quellkörper, sitting on thin subiculum composed of brown, septate hyphae. Peridium composed of brown to hyaline cells of textura angularis to textura prismatica, Munk pores present. Paraphyses absent. Asci polysporous, arising from a hyaline placenta-like tissue, radially extending into the locule around the Quellkörper from the base, unitunicate, clavate, apex rounded, apical ring inconspicuous, pedicellate, evanescent. Ascospores overlapping, hyaline, aseptate, boat-shaped to reniform, smooth-walled, with a filiform, flagella-like appendage at each end, guttulate. Asexual morph: Undetermined (adapted from Subramanian \& Sekar 1990).

Notes - The monotypic Janannfeldtia is typified by J. karwarensis, and has clavate asci and reniform ascospores with filiform appendage at each end (Subramanian \& Sekar 1990). This genus 
was initially placed in Coronophorales (Subramanian \& Sekar 1990), but assigned to Nitschkiaceae (Eriksson \& Hawksworth 1987, Lumbsch \& Huhndorf 2010, Maharachchikumbura et al. 2016, Hyde et al. 2020e, Index Fungorum 2021). We found that Janannfeldtia is similar to Biciliosporina in having subglobose ascomata with Quellkörper, clavate asci and ascospores with filiform appendage at each end, although the latter has 8-spored asci (Subramanian \& Sekar 1990).

Janannfeldtia karwarensis Subram. \& Sekar, Kavaka 18(1-2): 70 (1993) [1990]

Fig $15 n$

Facesoffungi number: FoF 10160

Saprobic on wood. Sexual morph: Ascomata solitary to gregarious, immersed to erumpent thought the bark of substrate or superficial on decorticated wood, sitting on thin subiculum composed of brown, septate hyphae, coriaceous to membranaceous, globose to subglobose, dark brown to black, the apex collapsing when dry, lacking ostioles, with Quellkörper. Peridium composed of brown to hyaline cells of textura angularis to textura prismatica, Munk pores present. Paraphyses absent. Asci polysporous, arising from a hyaline placenta-like tissue, radially extending into the locule around the Quellkörper from the base, unitunicate, clavate, apex rounded, apical ring inconspicuous, pedicellate, evanescent. Ascospores overlapping, hyaline, aseptate, boat-shaped to reniform, smooth-walled, with a filiform, flagella-like appendage at each end, guttulate. Asexual morph: Undetermined (adapted from Subramanian \& Sekar 1990).

Known hosts and distribution - on decayed wood in India (type locality) (Subramanian \& Sekar 1990).

Notes - Janannfeldtia karwarensis is characterized by subglobose ascomata, polysporous asci arising from a hyaline placenta-like tissue, radially extending into the locule around the Quellkörper from the base and ascospores with filiform appendage at each end (Subramanian \& Sekar 1990).

Lasiosphaeriopsis D. Hawksw. \& Sivan., in Hawksworth, Trans. Br. mycol. Soc. 74(2): 371 (1980)

Saprobic or parasitic on lichen. Sexual morph: Ascomata perithecial, gregarious, superficial, sitting on a subiculum composed of brown, septate hyphae, carbonaceous, turbinate, obovoid to subglobose, black, tuberculate, ostiolate, with periphyses. Peridium comprising black carbonaceous tissues at outer layer, inner layer composed of membranaceous, brown to hyaline cells of textura angularis to textura prismatica, Munk pores present. Paraphyses absent or cylindrical, septate, constricted at the septum. Asci 2-, 4- to 8-spored, unitunicate, clavate to cylindrical, apex rounded, apical ring inconspicuous, with long pedicel, evanescent. Ascospores uni- to bi-seriate, broadly fusiform, hyaline, aseptate when young, becoming brown to dark brown, 3-septate, rarely multiseptate, sometimes constricted at the septum, smooth-walled, guttulate. Asexual morph: Undetermined (adapted from Hawksworth 1980, Pérez-Ortega \& Halici 2008).

Notes - Lasiosphaeriopsis, a lichenicolous genus, typified by L. salisburyi has tuberculate ascomata, clavate asci and broadly fusiform ascospores (Hawksworth 1980). Lasiosphaeriopsis species were reported on Amygdalaria, Peltigera, Pilophorus, Porpidia, Stereocaulon in America, Asia and Europe (Pérez-Ortega \& Halici 2008). This genus was initially placed in Coronophorales (Hawksworth 1980), and subsequently assigned to Nitschkiaceae (Eriksson \& Hawksworth 1987, Hyde et al. 2020e, Index Fungorum 2021).

Lasiosphaeriopsis salisburyi D. Hawksw. \& Sivan., in Hawksworth, Trans. Br. mycol. Soc. 74(2): 373 (1980)

Fig. 18

Facesoffungi number: FoF 10064

Saprobic or parasitic on lichen. Sexual morph: Ascomata 170-310 $\times 210-370 \mu \mathrm{m}(\bar{x}=245 \times$ $310 \mu \mathrm{m}, \mathrm{n}=10$ ), perithecial, gregarious, superficial, sitting on a subiculum composed of brown, septate hyphae, 3-7 $\mu \mathrm{m}$ wide, carbonaceous, turbinate, obovoid to subglobose, black, tuberculate, ostiolate, with periphyses. Peridium 35-110 $\mu \mathrm{m}$ wide, comprising three layers, outer layer composed of black carbonaceous tissues; middle layer composed of membranaceous, dark brown to pale brown cells of textura angularis, rarely Munk pores present; inner layer composed of 
membranaceous, hyaline cells of textura prismatica. Paraphyses 4-9 $\mu \mathrm{m}$ wide, cylindrical, septate, constricted at the septum, evanescent. Asci (90-)100-110(-120) $\times(14-) 16-18(-22) \mu \mathrm{m}(\bar{x}=105 \times$ $17 \mu \mathrm{m}, \mathrm{n}=20$ ), 2- to 4-spored, unitunicate, clavate to cylindrical, apex rounded, apical ring inconspicuous, pedicellate, evanescent. Ascospores $(22-) 25-30(-35) \times 6.5-9 \mu \mathrm{m}(\bar{x}=27 \times 8 \mu \mathrm{m}, \mathrm{n}$ $=50$ ), bi-seriate, broadly fusiform, hyaline, aseptate when young, becoming 3 -septate and brown to olivaceous brown at middle cells, constricted at the septum, smooth-walled, guttulate. Asexual morph: Undetermined (adapted from Hawksworth 1980).

Material examined - UK, England, Lancashire, Ainsdale, Hillside Sandhills, on thallus of Peltigera rufescens, 23 March 1951, G. Salisbruy (IMI-80468, holotype).

Known hosts and distribution - on thallus of Peltigera rufescens (Peltigeraceae) in the UK (type locality) (Hawksworth 1980).

Notes - Lasiosphaeriopsis salisburyi is similar to Rhagadostoma lichenicola, but differs from it in the possessing of 3-septate ascospores, whereas those of the latter are 0-1-septate (Hawksworth 1980).

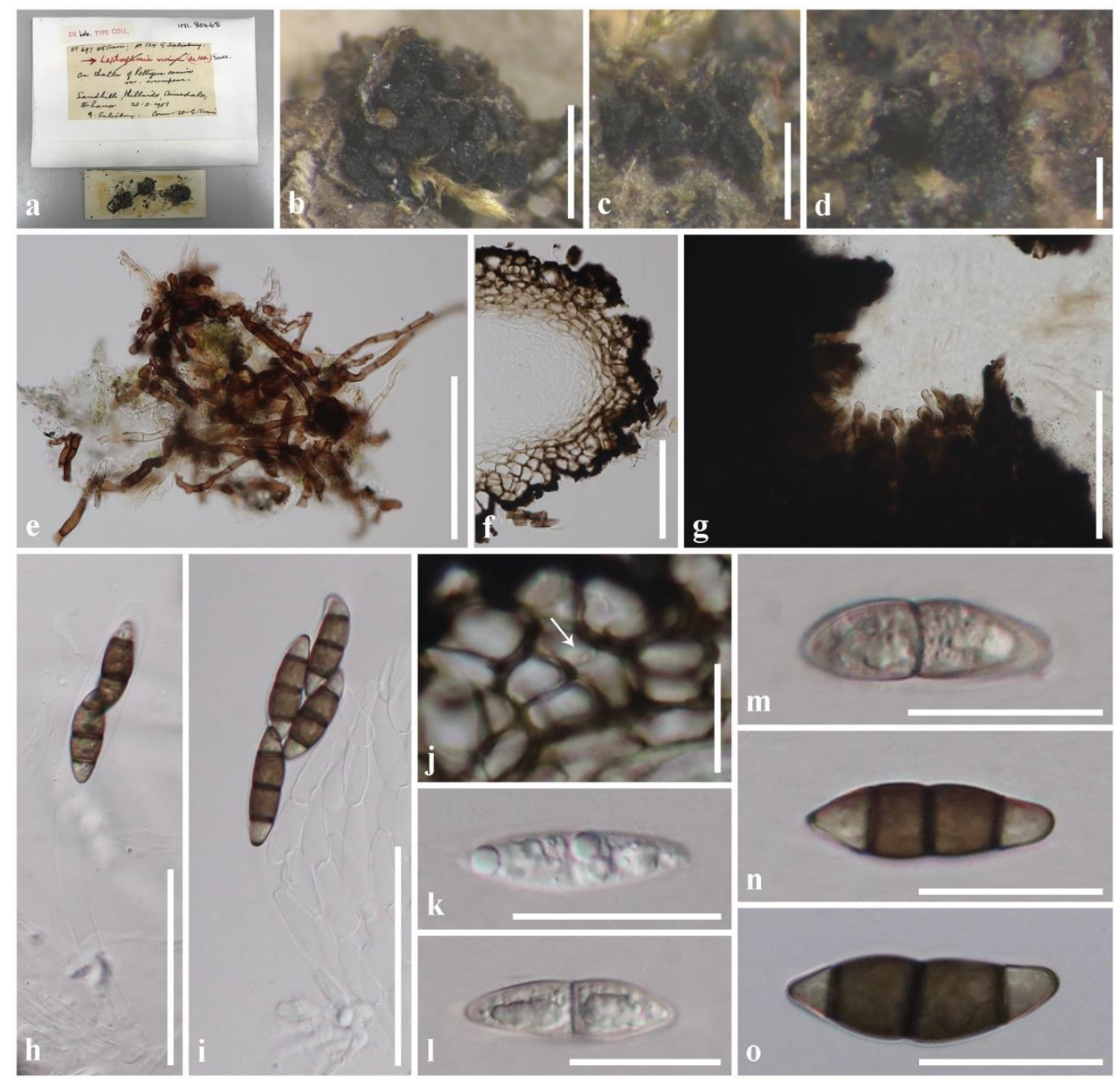

Figure 18 - Lasiosphaeriopsis salisburyi: (IMI-80468, holotype). a Material label. b-d Ascomata on lichen. e Subiculum composed of brown, septate hyphae. f Peridium. g Ostiole. h-i Asci with paraphyses. j Munk pore. $\mathrm{k}-\mathrm{O}$ Ascospores. Scale bars: $\mathrm{b}=1 \mathrm{~mm}, \mathrm{c}=500 \mu \mathrm{m}, \mathrm{d}=200 \mu \mathrm{m}, \mathrm{e}=100$ $\mu \mathrm{m}, \mathrm{f}-\mathrm{i}=50 \mu \mathrm{m}, \mathrm{k}-\mathrm{O}=20 \mu \mathrm{m}, \mathrm{j}=10 \mu \mathrm{m}$.

Loranitschkia Lar.N. Vassiljeva, Mikol. Fitopatol. 24(3): 207 (1990)

Saprobic on wood. Sexual morph: Ascomata scattered to gregarious, superficial, sitting on thin subiculum, pyriform to subglobose, tuberculate, black, the apex collapsing when dry, lacking 
ostioles. Peridium composed of brown to hyaline cells of porous texture. Paraphyses absent. Asci 8-spored, unitunicate, clavate, apex rounded, apical ring inconspicuous, pedicellate, evanescent. Ascospores bi-seriate, hyaline, clavate, with one middle septum, apex rounded, attenuated in a filiform, flagella-like, sometimes 1-septate appendage at base, smooth-walled, guttulate. Asexual morph: Undetermined (adapted from Vasilyeva et al. 2010).

Notes - The monotypic Loranitschkia was introduced by Vasilyeva (1990) from Russia, and it is characterized by tuberculate ascomata, clavate asci and clavate ascospores with a long flagellalike appendage (Vasilyeva et al. 2010). This genus is placed in Nitschkiaceae based on the characteristics of ascomata similar to Nitschkia (Vasilyeva et al. 2010).

Loranitschkia viticola Lar.N. Vassiljeva [as 'Loranitschki’], Mikol. Fitopatol. 24(3): 207 (1990)

Facesoffungi number: FoF 10161

Fig. $15 i$

Saprobic on wood. Sexual morph: Ascomata scattered to gregarious, superficial, sitting on thin subiculum, pyriform to subglobose, black, the apex collapsing when dry, lacking ostioles. Peridium composed of brown to hyaline cells of porous texture. Paraphyses absent. Asci 8-spored, unitunicate, clavate, apex rounded, apical ring inconspicuous, pedicellate, evanescent. Ascospores bi-seriate, hyaline, clavate, with one middle septum, apex rounded, attenuated in a filiform, flagella-like, sometimes 1-septate appendage at base, smooth-walled, guttulate. Asexual morph: Undetermined (adapted from Vasilyeva et al. 2010).

Known hosts and distribution - on decayed wood of Vitis in Russia (type locality) (Vasilyeva et al. 2010).

Notes - The ascomata of Loranitschkia viticola are similar to Nitschkia species, but the wall in Loranitschkia viticola is thicker than in Nitschkia species, in addition, the former has porous texture of ascomata walls, different from the rounded to angular wall cells of the latter (Vasilyeva et al. 2010).

Nitschkia G.H. Otth ex P. Karst., Bidr. Känn. Finl. Nat. Folk 23: 13 (1873)

Saprobic on wood. Sexual morph: Subiculum absent or composed of brown to dark brown, septate, branched, sinuous hyphae with metallic iridescence. Ascomata perithecial or without an external opening, gregarious, erumpent or superficial, sitting on or in a subiculum, carbonaceous or coriaceous, black, turbinate, cupuliform to subglobose, tuberculate, the apex collapsing when dry, with periphyses inside of the inconspicuous ostioles or lacking ostioles. Peridium composed of membranaceous, brown to hyaline cells of textura angularis to textura prismatica, sometimes Munk pores present. Paraphyses absent or unbranched, septate. Asci 4- to 8-spored, unitunicate, clavate to cylindrical, apex blunt or rounded, apical ring inconspicuous, with long pedicel, evanescent. Ascospores bi-seriate to overlapping, hyaline to brown, aseptate or septate, allantoid to subcylindrical, sometimes slightly curved, smooth-walled, mostly with guttules. Asexual morph: Undetermined (adapted from Fitzpatrick 1923, Subramanian \& Sekar 1990).

Notes - Fuckel (1870b) introduced the generic name Nitschkia and described N. fuckelii based on Sphaeria cupularis Fries. Subsequently, Karsten (1873) stated that S. cupularis Fries is illegitimate as it has an earlier homonym S. cupularis Pers.; thus, he clarified the genus Nitschkia and introduced $N$. cupularis as generic type. This genus is characterized by turbinate ascomata, clavate asci and allantoid ascospores and currently includes 58 species (Hyde et al. 2020e, Index Fungorum 2021). Molecular data is available for five species, N. calyculus, N. grevillii, $N$. meniscoidea, N. pezizoidea, N. tetraspora (Huhndorf et al. 2004b, Mugambi \& Huhndorf 2010). In this study, N. calyculus, $N$. grevillii and $N$. tetraspora clustered as a sister clade of Acanthonitschkea (73\%ML/0.95BY, Fig. 1) and $N$. meniscoidea nests in Nitschkiaceae (100\%ML/1.00BY, Fig. 1), but N. pezizoidea is basal to Bertiaceae (62\%ML, Fig. 1). 
Facesoffungi number: FoF 01122

Saprobic on wood. Sexual morph: Ascomata 325-550 $\times 210-450 \mu \mathrm{m}(\bar{x}=500 \times 350 \mu \mathrm{m}, \mathrm{n}=$ 10 ), gregarious, erumpent through the bark of host to superficial, coriaceous to membranaceous, black, turbinate, cupuliform to subglobose, tuberculate, the apex collapsing when dry, lacking ostioles, with a small papillate ostiole-like structure without an external opening and periphyseslike hyphae. Peridium 30-55 $\mu \mathrm{m}$ wide, comprising three layers, outer layer composed of black tissue; middle layer composed of membranaceous, dark brown to brown cells of textura angularis, Munk pores present; inner layer composed of membranaceous, hyaline cells of textura prismatica. Paraphyses 5-12 $\mu \mathrm{m}$ wide, cylindrical, unbranched, septate, constricted at the septum. Asci (45)50-60(-70) $\times(7-) 8-10(-12) \mu \mathrm{m}(\bar{x}=58 \times 9 \mu \mathrm{m}, \mathrm{n}=30), 8$-spored, unitunicate, clavate, apex rounded, pedicellate, evanescent. Ascospores (7.5-)10-12(-14) $\times 2-4 \mu \mathrm{m}(\bar{x}=10.5 \times 2.5 \mu \mathrm{m}, \mathrm{n}=$ $50)$, bi-seriate, hyaline, aseptate, allantoid to subcylindrical, slightly curved, smooth-walled, mostly with guttules. Asexual morph: Undetermined.

Material examined - Austria, Niederösterreich, Wienerwald, Rekawinkel, on decayed wood of Prunus padus, September 1949, F. Petrak (S-F117662); Germany, on decayed wood of Acer and Prunus, K.W. Fuckel (BR-5020096960571).

Known hosts and distribution - on decayed wood of Acer, Prunus, Rubus, Sambucus, Syringa, Tilia and Ulmus in Austria, Germany (type locality), Russia and the USA (Karsten 1873, Vasilyeva et al. 2010).

Notes - We were unable to obtain the type material. Therefore, we re-examined the authentic specimens (F117662 and 5020096960571) collected by Petrak and Fuckel, respectively.

Rhagadostoma Körb., Parerga lichenol. (Breslau) 5: 472 (1865)

Saprobic or parasitic on lichen. Sexual morph: Subiculum absent or composed of brown to dark brown, septate, branched, sinuous hyphae. Ascomata perithecial, gregarious, superficial, sitting on or in a subiculum, carbonaceous, black, globose to subglobose, tuberculate, the apex collapsing when dry, with periphyses inside of the inconspicuous ostioles. Peridium composed of membranaceous, brown to hyaline cells of textura angularis to textura prismatica, Munk pores present. Paraphyses absent or unbranched or branched, septate. Asci 2- to 8-spored, unitunicate, clavate, apex rounded and thickening, apical ring inconspicuous, pedicellate, evanescent. Ascospores bi-seriate to overlapping, hyaline to brown, 1-septate, rarely multi-septate, ellipsoidal, broadly fusiform to cylindrical, sometimes slightly curved, smooth-walled, mostly with guttules. Asexual morph: Undetermined (adapted from Navarro-Rosinés \& Hladun 1994, Navarro-Rosinés et al. 1999).

Notes - Körber (1865) established Rhagadostoma based on R. corrugatum. Subsequently, Saccardo (1882a) stated that $R$. corrugatum is a synonym of Bertia lichenicola, and Keissler (1930) introduced $R$. lichenicola as the current name of $B$. lichenicola and $R$. corrugatum. However, the first identified $R$. corrugatum is regarded as the name of the type species of Rhagadostoma (Maharachchikumbura et al. 2016, Hyde et al. 2020e). This lichenicolous genus was initially placed in Sordariales (Navarro-Rosinés \& Hladun 1994, Navarro-Rosinés et al. 1999). Huhndorf et al. (2004b) proposed that Rhagadostoma is morphologically related to Bertia but its phylogenetic position remains unknown. However, subsequently, this genus was assigned to Nitschkiaceae (Lumbsch \& Huhndorf 2010, Hyde et al. 2020e, Index Fungorum 2021).

Rhagadostoma corrugatum Körb., Parerga lichenol. (Breslau) 5: 473 (1865)

Fig. 20

Facesoffungi number: FoF 10065

Saprobic or parasitic on lichen. Sexual morph: Subiculum absent or composed of brown to dark brown, septate, branched, sinuous hyphae 60-90 $\mu \mathrm{m}$ wide. Ascomata 300-420 $\mu \mathrm{m}(\bar{x}=370$ $\mu \mathrm{m}, \mathrm{n}=10$ ) diam., perithecial, gregarious, superficial, sitting on or in a subiculum, carbonaceous, black, globose to subglobose, tuberculate, the apex collapsing when dry, with periphyses inside of the inconspicuous ostioles. Peridium 60-90 $\mu \mathrm{m}$ wide, comprising three layers, outer layer composed of black tissue; middle layer composed of membranaceous, brown to olivaceous brown 
cells of textura angularis, Munk pores present; inner layer composed of membranaceous, hyaline cells of textura prismatica. Paraphyses absent. Asci 2- to 4-spored, unitunicate, clavate, apex rounded and thickening, apical ring inconspicuous, pedicellate, evanescent. Ascospores (40-)45$55(-68) \times(6-) 8-10(-15) \mu \mathrm{m}(\bar{x}=50 \times 9.5 \mu \mathrm{m}, \mathrm{n}=50)$, bi-seriate to overlapping, hyaline to brown, 1-septate, rarely multi-septate, ellipsoidal, broadly fusiform to cylindrical, sometimes slightly curved, smooth-walled, mostly with guttules. Asexual morph: Undetermined.

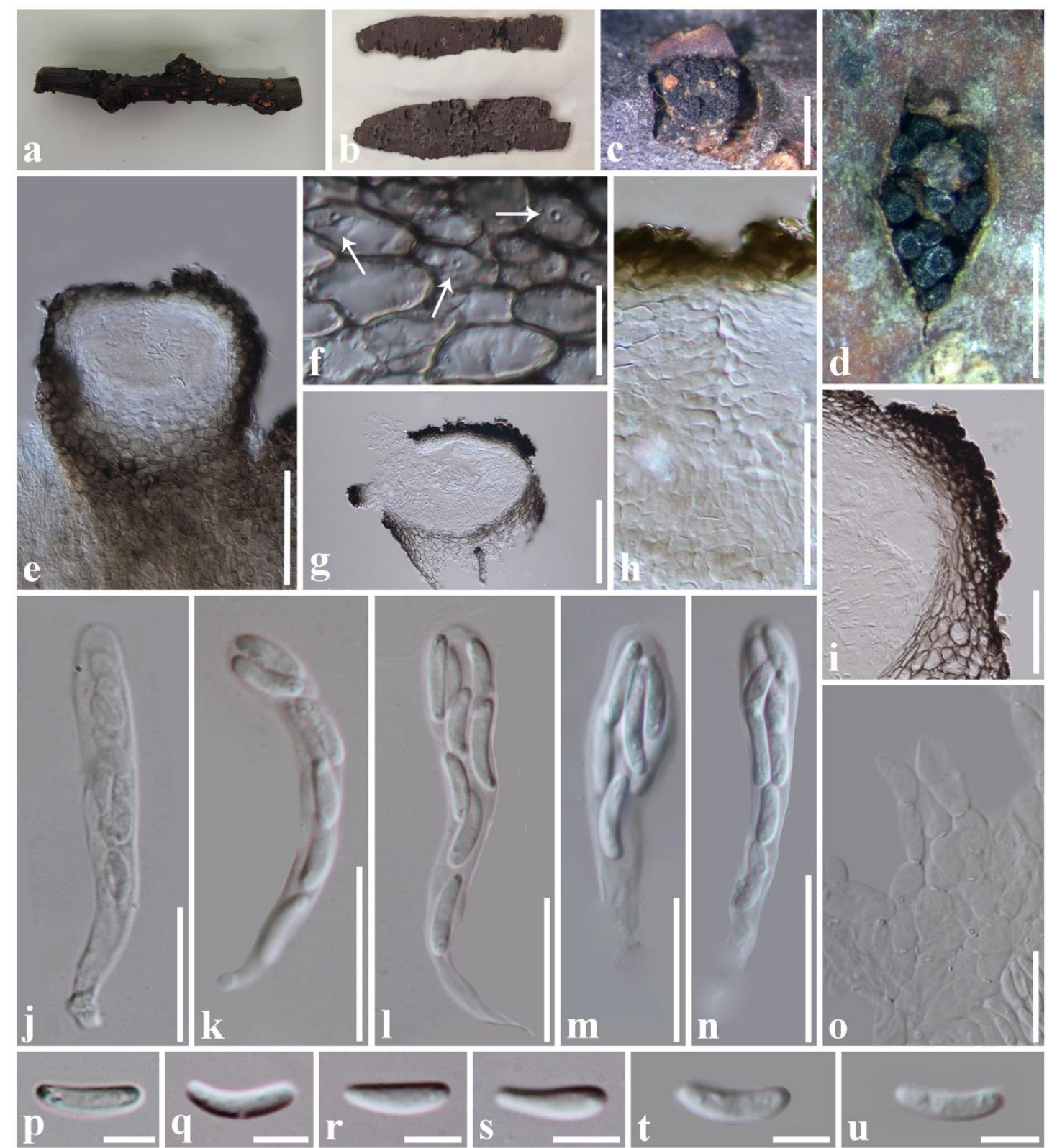

Figure 19 - Nitschkia cupularis: a, c, e, h, m-n, t-u (S-F117662); b, d, f-g, i-1, o-s (BR5020096960571). a-b Material. c-d Ascomata erumpent through the bark of host. e, g Ascoma cross section. f Munk pores (arrow). h Ostiole-like structure without an external opening. i Peridium. j-n Asci. o Paraphyses. p-u Ascospores. Scale bars: c- $d=1 \mathrm{~mm}, \mathrm{~g}=200 \mu \mathrm{m}, \mathrm{e}=100$ $\mu \mathrm{m}, \mathrm{h}-\mathrm{i}=50 \mu \mathrm{m}, \mathrm{f}, \mathrm{j}-\mathrm{O}=20 \mu \mathrm{m}, \mathrm{p}-\mathrm{u}=5 \mu \mathrm{m}$.

Material examined - Norway, Oppland, Sønderland, Nymoen, on Solorina crocea growing on Calamagrostis, 4 September 1984, O.E. Eriksson and J.Z. Yue (NY-03380689).

Known hosts and distribution - on thallus of Solorina crocea in Austria, Finland, Germany, Italy, Norway, Spain (type locality) and the UK (Körber 1865, Saccardo 1882a, Olivier 1907, Hafellner 2015). 
Notes - Rhagadostoma corrugatum was found on Solorina crocea (Körber 1865). We were unable to obtain the type material and, therefore, re-examined an authentic sample on $S$. crocea.

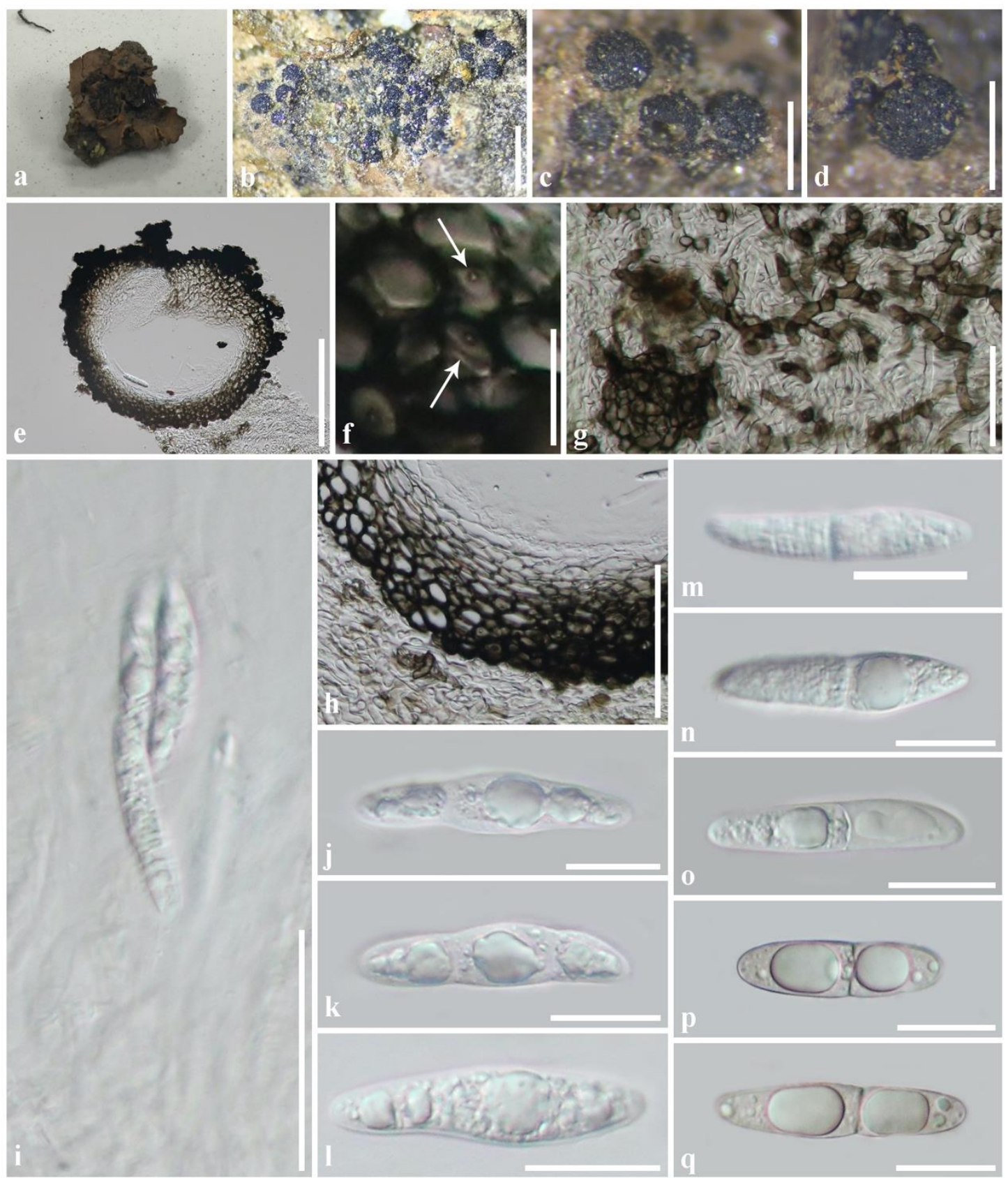

Figure 20 - Rhagadostoma corrugatum: (NY-03380689). a Material. b-d Ascomata on the host. e Ascoma cross section. f Munk pores (arrow). g Subiculum composed of brown hyphae. h Peridium. i Ascus. j-q Ascospores. Scale bars: $b=1 \mathrm{~mm}, \mathrm{c}-\mathrm{d}=500 \mu \mathrm{m}, \mathrm{e}=200 \mu \mathrm{m}, \mathrm{h}=100$ $\mu \mathrm{m}, \mathrm{g}, \mathrm{i}=50 \mu \mathrm{m}, \mathrm{f}, \mathrm{j}-\mathrm{q}=20 \mu \mathrm{m}$.

Rhagadostomella Etayo, Biblthca Lichenol. 84: 109 (2002)

Saprobic or parasitic on lichen. Sexual morph: Ascomata perithecial, gregarious, erumpent to superficial, sitting on a subiculum, carbonaceous, olivaceous brown or dark brown to black, globose to subglobose, tuberculate, the apex collapsing when dry, ostiolate, periphysate. Peridium composed of membranaceous, brown cells of textura epidermoidea to textura angularis. Paraphyses absent. Asci 4- to 8-spored, unitunicate or bitunicate, broadly clavate, apex blunt to rounded and thickening, apical ring conspicuous after the ascospores released, pedicellate, evanescent. Ascospores overlapping at the apex, hyaline, aseptate to 1- or 2-septate, fusiform to 
cylindrical, sometimes slightly curved, smooth-walled, mostly with guttules. Asexual morph: Undetermined (adapted from Etayo 2002, Flakus et al. 2019).

Notes - Rhagadostomella, a lichenicolous genus, was introduced by Etayo (2002) based on $R$. gregaria from Colombia. A second species $R$. hypolobariella which has bitunicate asci and growing on Lobariella pallida in Bolivia was introduced (Flakus et al. 2019). This genus is placed in Nitschkiaceae but no molecular data is available for the Rhagadostomella (Etayo 2002, Flakus et al. 2019).

Rhagadostomella gregaria Etayo, Biblthca Lichenol. 84: 109 (2002)

Fig. $15 r-s$

Facesoffungi number: FoF 10162

Saprobic or parasitic on lichen. Sexual morph: Ascomata perithecial, gregarious, erumpent to superficial, sitting on a subiculum, carbonaceous, dark brown to black, globose to subglobose, tuberculate, the apex collapsing when dry, ostiolate, periphysate. Peridium composed of membranaceous, brown cells of textura epidermoidea to textura angularis. Paraphyses absent. Asci 8-spored, unitunicate, broadly clavate, apex blunt and thickening, apical ring conspicuous after the ascospores released, pedicellate, evanescent. Ascospores overlapping at the apex, hyaline, 1-septate, fusiform to cylindrical, sometimes slightly curved, smooth-walled, mostly with guttules. Asexual morph: Undetermined (adapted from Etayo 2002).

Known hosts and distribution - on thallus of Sticta weigelii in Colombia (type locality) and Ecuador (Etayo 2002, 2017).

Notes - Rhagadostomella gregaria was collected on Sticta weigelii in Colombia and Ecuador and is characterzied by tuberculate ascomata, broadly clavate asci and fusiform to cylindrical ascospores (Etayo 2002, 2017).

Tortulomyces Lar.N. Vassiljeva, S.L. Stephenson, Chernyshev \& K.D. Hyde, Mycoscience 54(1): 111 (2013)

Saprobic on wood. Sexual morph: Subiculum composed of brown, branched, septate, sinuous hyphae. Ascomata gregarious, superficial, sitting on a subiculum, brown to black, turbinate, subglobose, tuberculate, the apex collapsing when dry, lacking ostioles. Peridium composed of brown to hyaline cells of textura angularis to textura prismatica. Paraphyses cylindrical, septate. Asci 8-spored, unitunicate, clavate to cylindrical, apex rounded, apical ring inconspicuous, with long pedicel, evanescent. Ascospores bi-seriate to overlapping, pale brown, 1-septate, ellipsoidal, smooth-walled, guttulate. Asexual morph: Undetermined (adapted from Vasilyeva et al. 2013).

Notes - The monotypic genus Tortulomyces was introduced by Vasilyeva et al. (2013) for $T$. thailandicus growing on dead branches in Thailand. Tortulomyces was placed in Nitschkiaceae, but no molecular data is available for this genus (Vasilyeva et al. 2013).

Tortulomyces thailandicus Lar.N. Vassiljeva, S.L. Stephenson, Chernyshev \& K.D. Hyde, Mycoscience 54(1): 111 (2013)

Fig. $15 \mathrm{u}$

Facesoffungi number: FoF 10163

Saprobic on wood. Sexual morph: Subiculum composed of brown, branched, septate, sinuous hyphae. Ascomata gregarious, superficial, sitting on a subiculum, brown to black, turbinate, subglobose, tuberculate, the apex collapsing when dry, lacking ostioles. Peridium composed of brown to hyaline cells of textura angularis to textura prismatica. Paraphyses cylindrical, septate. Asci 8-spored, unitunicate, clavate to cylindrical, apex rounded, apical ring inconspicuous, with long pedicel, evanescent. Ascospores bi-seriate to overlapping, pale brown, 1-septate, ellipsoidal, smooth-walled, guttulate. Asexual morph: Undetermined (adapted from Vasilyeva et al. 2013).

Known hosts and distribution - on decayed wood in Thailand (type locality) (Vasilyeva et al. 2013).

Notes - Tortulomyces thailandicus grows on dead branches in Thailand and has subglobose ascomata without ostioles, clavate asci and ellipsoidal ascospores, but there is no available molecular data for this species (Vasilyeva et al. 2013). 
Scortechiniaceae Huhndorf, A.N. Mill. \& F.A. Fernández, in Huhndorf, Miller \& Fernández, Mycol. Res. 108(12): 1387 (2004)

Saprobic on wood. Sexual morph: Subiculum absent or composed of numerous or rare, brown to dark brown, branched, septate hyphae, with dichotomously branched, tapering or rounded ends. Ascomata scattered or gregarious, semi-immersed or erumpent or superficial, sitting on or in a subiculum, carbonaceous or coriaceous, brown to black, turbinate, globose, obpyriform to subglobose, the apex collapsing when dry, tuberculate, glabrous or spiny, lacking ostioles, with a conical Quellkörper. Peridium usually outer layer composed of carbonaceous, black tissue; inner layer composed of membranaceous, brown to hyaline cells of textura angularis to textura prismatica, sometimes Munk pores present. Paraphyses absent or filiform, branched or unbranched, septate, evanescent. Asci 8- or multi-spored, unitunicate, clavate to cylindrical, pedicellate or sessile, apex blunt or rounded, without apical ring, evanescent. Ascospores bi-seriate to overlapping, hyaline to brown or olivaceous brown, allantoid, ellipsoidal, ovoid to oval, straight to slightly curved, usually aseptate, smooth-walled, sometimes with mucilaginous appendages, mostly with guttules. Asexual morph: Conidiophores erect, solitary, straight to flexuous. Conidiogenous cells hyaline, smooth-walled, subcylindrical. Conidia hyaline, aseptate, smoothwalled, ellipsoidal to ovoid, guttulate (adapted from Huhndorf et al. 2004b, Hyde et al. 2020e).

Type genus - Scortechinia Sacc.

Notes - Scortechiniaceae was established by Huhndorf et al. (2004b) based on the wellsupported clade of Euacanthe, Neofracchiaea and Scortechinia in LSU sequence analyses. The Quellkörper was accepted as a main character to define this family (Huhndorf et al. 2004b). Later, Biciliospora, Coronophorella, Cryptosphaerella, Pseudocatenomycopsis, Scortechiniella, Scortechiniellopsis and Tympanopsis, were accommodated in this family based on phylogenetic results (Mugambi \& Huhndorf 2010, Crous et al. 2013, Hyde et al. 2020e). The members in this family are characterized by turbinate ascomata with Quellkörper, clavate asci and hyaline ascospores (Huhndorf et al. 2004b, Mugambi \& Huhndorf 2010).

We found that Cryptosphaerella should be redefined. Initially, Cryptosphaerella was introduced as a genus with similar morphology to Cryptosphaeria (Diatrypaceae) (Saccardo 1882a). Later, it was considered a member of Coronophoraceae (von Höhnel 1907). Cryptosphaerella is typified by $C$. nitschkei which has perithecial, immersed ascomata with ostioles and polysporous asci (Nitschke 1870, Saccardo 1882a). Some species with similar characteristics (such as $C$. anonae, $C$. coffaeiphila and $C$. cordobensis) were subsequently introduced to this genus, but no molecular data is available for these species (Spegazzini 1909, 1922, 1926). Mugambi \& Huhndorf (2010) sequenced six 'Cryptosphaerella' species lacking ostioles in the ascomata with Quellkörper. Therefore, Cryptosphaerella was assigned to Scortechiniaceae based on phylogenetic analyses of these six species. However, the type of Cryptosphaerella does not have unique Quellkörpers and Munk pores. We therefore transfer Cryptosphaerella to Sordariomycetes genera incertae sedis and redefine the six species introduced by Mugambi \& Huhndorf (2010) as Pseudocryptosphaerella and Neocryptosphaerella in Scortechiniaceae based on morphology and phylogenetic results.

\section{Biciliospora Petr., Sydowia 6(5-6): 429 (1952)}

Saprobic on wood. Sexual morph: Subiculum composed of numerous, brown to dark brown, branched, septate hyphae, with dichotomously branched, rounded ends. Ascomata scattered or gregarious, superficial, sitting in a subiculum, carbonaceous, brown to black, globose to subglobose, the apex collapsing when dry, tuberculate, glabrous, lacking ostioles, with a central, conical Quellkörper at apex. Peridium outer layer composed of carbonaceous, black tissue; inner layer composed of membranaceous, brown to hyaline cells of textura angularis to textura prismatica, Munk pores present. Paraphyses absent. Asci 8-spored, arising from a hyaline placentalike tissue, radially extending into the locule around the Quellkörper from the base, unitunicate, clavate, pedicellate, apex rounded, without apical ring, evanescent. Ascospores bi-seriate to overlapping, hyaline, ellipsoidal to fusiform, aseptate, smooth-walled, guttulate, with a filiform 
appendage at each end and usually recurved at opposite sides. Asexual morph: Undetermined (adapted from Petrak 1952).

Notes - The monotypic Biciliospora was introduced by Petrak (1952) for B. velutina and initially placed in Coronophorales. Subsequently, this genus was assigned in Coronophoraceae and even accepted as a synonym of Nitschkia (Müller \& von Arx 1973, Nannfeldt 1975, Subramanian \& Sekar 1990). However, molecular data of Biciliospora revealed that this genus nested in Scortechiniaceae (Mugambi \& Huhndorf 2010). In this study, Biciliospora is sister to Scortechiniella (85\%ML/1.00BY, Fig. 1) in Scortechiniaceae.

Biciliospora velutina Petr., Sydowia 6(5-6): 429 (1952)

Fig. 21

Facesoffungi number: FoF 10066

Saprobic on wood. Sexual morph: Subiculum composed of numerous, brown to dark brown, branched, septate hyphae 4.5-7.5 $\mu \mathrm{m}$ wide, with dichotomously branched, rounded ends. Ascomata 340-450 $\mu \mathrm{m}(\bar{x}=380 \mu \mathrm{m}, \mathrm{n}=10)$ diam., scattered or gregarious, superficial, sitting in a subiculum, carbonaceous, brown to black, globose to subglobose, the apex collapsing when dry, tuberculate, glabrous, lacking ostioles, with a central, conical Quellkörper at apex. Peridium 25-45 $\mu \mathrm{m}$ wide, comprising three layers, outer layer composed of carbonaceous, black tissue; middle layer composed of membranaceous, brown to reddish-brown cells of textura angularis, Munk pore present; inner layer membranaceous, composed of hyaline cells of textura prismatica. Paraphyses absent. Asci (65-)70-85(-90) $\times(14-) 16-20(-22) \mu \mathrm{m}(\bar{x}=75 \times 18 \mu \mathrm{m}, \mathrm{n}=20)$ at the ascosporebearing part, 8 -spored, arising from a hyaline placenta-like tissue, radially extending into the locule around the Quellkörper from the base, unitunicate, clavate, pedicellate, apex rounded, without apical ring, evanescent. Ascospores 25-30(-35) $\times 5-8 \mu \mathrm{m}(\bar{x}=28 \times 6 \mu \mathrm{m}, \mathrm{n}=50)$, bi-seriate to overlapping, hyaline, ellipsoidal to fusiform, aseptate, smooth-walled, guttulate, with a filiform appendage at each end and usually recurved at opposite sides. Asexual morph: Undetermined.

Material examined - Porto Rico, Utaada, on fallen branches in coffee grove, 20 October 1920, F.S. Earle (W-11051, holotype).

Known hosts and distribution - on fallen branches in coffee grove in Porto Rico (type locality) and Kenya (Petrak 1952, Mugambi \& Huhndorf 2010).

Notes - Biciliospora velutina was introduced by Petrak (1952) from Porto Rico and was sequenced by Mugambi \& Huhndorf (2010). In this study, B. velutina is sister to Scortechiniella similis (85\% ML/1.00BY, Fig. 1), differing from the latter in having polysporous asci with oval ascospores (von Arx \& Müller 1954).

Coronophorella Höhn., Sber. Akad. Wiss. Wien, Math.-naturw. Kl., Abt. 1 118: 1507 (1909)

Saprobic on wood. Sexual morph: Subiculum composed of numerous, brown to dark brown, branched, septate hyphae, with dichotomously branched, tapering ends. Ascomata scattered or gregarious, superficial, sitting in a subiculum, coriaceous, brown to black, globose to subglobose, the apex collapsing when dry, tuberculate, glabrous, lacking ostioles, with a central, conical Quellkörper touching the bottom of the locule. Peridium composed of membranaceous, brown to hyaline cells of textura angularis to textura prismatica, Munk pores present. Paraphyses absent. Asci 8-spored, arising from a hyaline placenta-like tissue, radially extending into the locule around the Quellkörper from the base, unitunicate, clavate to cylindrical, pedicellate, apex rounded, without apical ring, evanescent. Ascospores bi-seriate to overlapping, hyaline, reniform to allantoid, aseptate, smooth-walled, guttulate. Asexual morph: Undetermined (adapted from Penzig \& Saccardo 1897, Subramanian \& Sekar 1990).

Notes - The monotypic Coronophorella was initially placed in Coronophorales, and was considered to be a synonym of Nitschkia, Scortechinia and Tympanopsis based on morphology (Penzig \& Saccardo 1897, von Arx \& Müller 1954, Müller \& Arx 1955, Nannfeldt \& Santesson 1975). However, this genus was an independent branch of Scortechiniaceae in phylogenetic result (Mugambi \& Huhndorf 2010). In this study, Coronophorella is basal to Biciliospora, Pseudocryptosphaerella, Scortechiniella and Scortechiniellopsis in Scortechiniaceae (Fig. 1). 


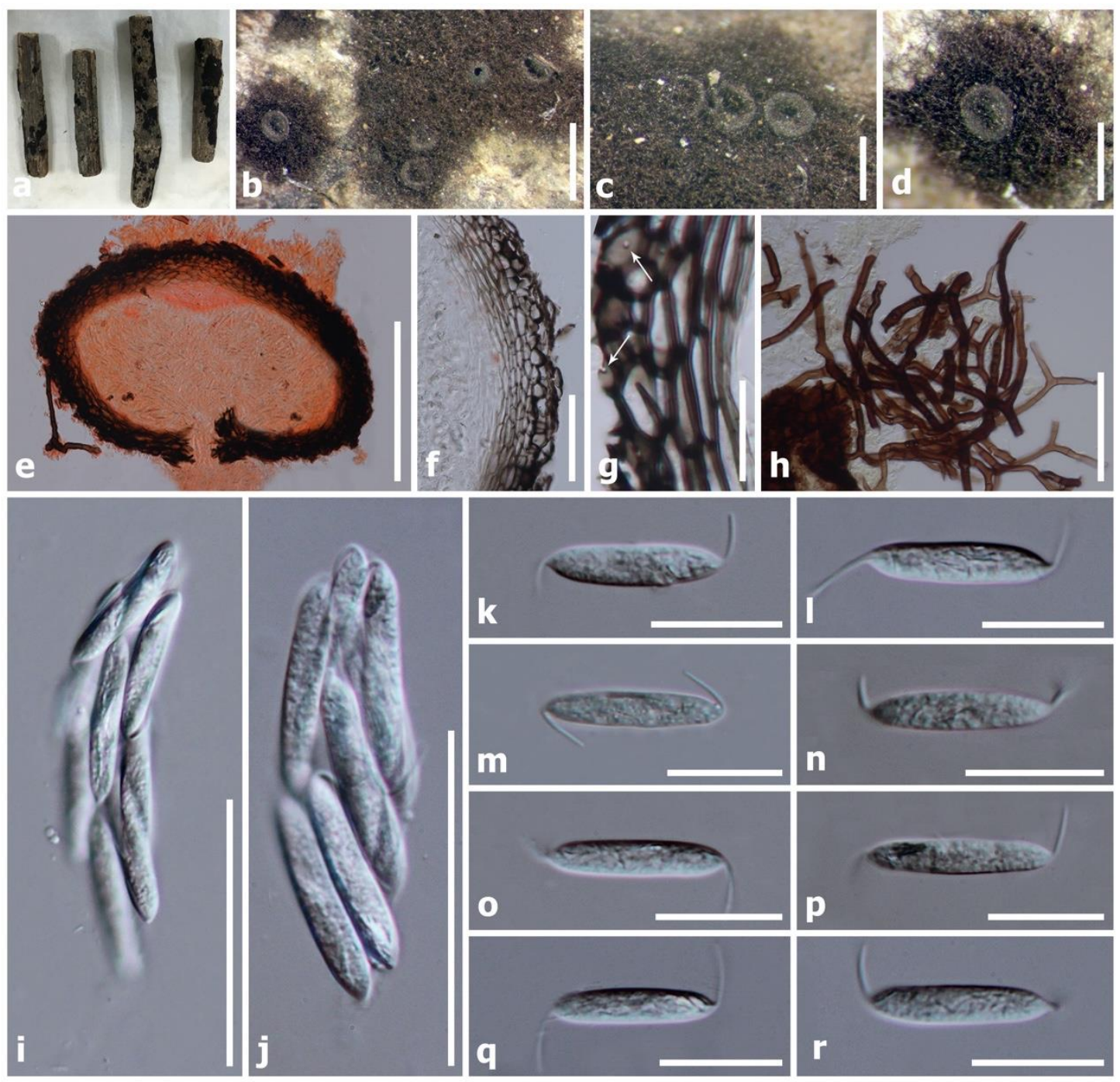

Figure 21 - Biciliospora velutina: (W-11051, holotype). a Material. b-d Ascomata sitting in a subiculum on host. e Ascoma cross section (in Congo red reagent). f Peridium. g Munk pores (arrow). h Septate hyphae. i-j Asci. k-r Ascospores. Scale bars: $b=1 \mathrm{~mm}, \mathrm{c}-\mathrm{d}=500 \mu \mathrm{m}, \mathrm{e}=200$ $\mu \mathrm{m}, \mathrm{f}, \mathrm{h}-\mathrm{j}=50 \mu \mathrm{m}, \mathrm{g}, \mathrm{k}-\mathrm{r}=20 \mu \mathrm{m}$.

Coronophorella chaetomioides (Penz. \& Sacc.) Höhn., Sber. Akad. Wiss. Wien, Math.-naturw. Kl., Abt. 1 118: 1507 (1909)

Fig. 24n-o

Basionym - Enchnoa chaetomioides Penz. \& Sacc., Malpighia 11(9-10): 390 (1897)

Facesoffungi number: FoF 10164

Saprobic on wood. Sexual morph: Subiculum composed of numerous, brown to dark brown, branched, septate hyphae, with dichotomously branched, tapering ends. Ascomata scattered or gregarious, superficial, sitting in a subiculum, coriaceous, brown to black, globose to subglobose, the apex collapsing when dry, tuberculate, glabrous, lacking ostioles, with a central, conical Quellkörper almost or touching the bottom of the locule. Peridium composed of membranaceous, brown to hyaline cells of textura angularis to textura prismatica, Munk pores present. Paraphyses absent. Asci 8-spored, arising from a hyaline placenta-like tissue, radially extending into the locule around the Quellkörper from the base, unitunicate, clavate to cylindrical, pedicellate, apex rounded, without apical ring, evanescent. Ascospores bi-seriate to overlapping, hyaline, reniform to allantoid, aseptate, smooth-walled, guttulate. Asexual morph: Undetermined (adapted from Penzig \& Saccardo 1897, Subramanian \& Sekar 1990). 
Known hosts and distribution - on decayed wood in Ghana, India, Indonesia (type locality), Kenya and Sierra Leone (Penzig \& Saccardo 1897, Nannfeldt \& Santesson 1975, Subramanian \& Sekar 1990, Mugambi \& Huhndorf 2010).

Notes - Coronophorella chaetomioides was originally introduced as Enchnoa chaetomioides from Indonesia (Penzig \& Saccardo 1897). It is characterized by ascomata without ostioles, clavate asci and reniform to allantoid ascospores (Penzig \& Saccardo 1897, Subramanian \& Sekar 1990). Mugambi \& Huhndorf (2010) accepted this species in Scortechiniaceae based on molecular data. In this study, C. chaetomioides nests in Scortechiniaceae (Fig. 1).

Euacanthe Theiss., Annls mycol. 15(3/4): 272 (1917)

Saprobic on wood. Sexual morph: Subiculum composed of numerous, brown to dark brown, branched, septate hyphae, with dichotomously branched, tapering ends. Ascomata densely gregarious, superficial, sitting on a subiculum, coriaceous, black, turbinate, cupuliform to subglobose, the apex collapsing when dry, tuberculate, with spiculate, erect setae, lacking ostioles, with a central, conical Quellkörper. Peridium composed of membranaceous, brown to hyaline cells of textura angularis to textura prismatica, Munk pores present. Paraphyses absent. Asci 8-spored, arising from a hyaline placenta-like tissue, radially extending into the locule around the Quellkörper from the base, unitunicate, clavate, pedicellate, apex rounded, without apical ring, evanescent. Ascospores bi-seriate to overlapping, hyaline, reniform, aseptate, smooth-walled, guttulate. Asexual morph: Undetermined (adapted from Engler 1895, Subramanian \& Sekar 1990).

Notes - The monotypic Euacanthe was introduced based on Meliolopsis usambarensis (Theissen 1917). Nannfeldt \& Santesson (1975) transferred this genus as Acanthonitschkea (Nitschkiaceae) and placed E. usambarensis as a synonym of A. foveolata. Subsequently, Subramanian \& Sekar (1990) assigned Euacanthe in Coronophorales and accepted E. foveolata based on A. foveolata as the only species in this genus. Mugambi \& Huhndorf (2010) sequenced E. foveolata and found it nested in Scortechiniaceae. We use the original name, E. usambarensis, as the current name of type species to avoid confusion in future work. In this study, Euacanthe is sister to Pseudocatenomycopsis (0.97BY, Fig. 1) in Scortechiniaceae.

Euacanthe usambarensis (Rehm) Theiss., Annls mycol. 15(3/4): 272 (1917) Fig. 22 Basionym - Meliolopsis usambarensis Rehm, in Hennings, Pflanzenw. Ost-Afrikas Nachbarg., Teil C: 31 (1895)

Facesoffungi number: FoF 10067

Saprobic on wood. Sexual morph: Subiculum composed of numerous, brown to dark brown, branched, septate hyphae 6-14 $\mu \mathrm{m}$ wide, with dichotomously branched, tapering ends. Ascomata 630-1250 $\times 420-690 \mu \mathrm{m}(\bar{x}=985 \times 550 \mu \mathrm{m}, \mathrm{n}=10)$, densely gregarious, superficial, sitting on a subiculum, coriaceous, black, turbinate, cupuliform to subglobose, the apex collapsing when dry, tuberculate, with spiculate, erect setae 10-15 $\mu \mathrm{m}$ wide, lacking ostioles, with a central, conical Quellkörper. Peridium 60-90 $\mu \mathrm{m}$ wide, membranaceous, comprising two layers, outer layer composed of dark brown to brown cells of textura angularis, Munk pores present; inner layer composed of hyaline cells of textura prismatica. Paraphyses absent. Asci (14-)18-21(-23) $\times 7-9$ $\mu \mathrm{m}(\bar{x}=20 \times 8 \mu \mathrm{m}, \mathrm{n}=20)$ at ascospore-bearing part, 8-spored, arising from a hyaline placentalike tissue, radially extending into the locule around the Quellkörper from the base, unitunicate, clavate, pedicellate, apex rounded, without apical ring, evanescent. Ascospores $(4.5-) 5-6(-7) \times$ 2.5-4 $\mu \mathrm{m}(\bar{x}=5.5 \times 3 \mu \mathrm{m}, \mathrm{n}=50)$, bi-seriate to overlapping, hyaline, reniform, aseptate, smoothwalled, guttulate. Asexual morph: Undetermined (adapted from Engler 1895, Subramanian \& Sekar 1990).

Material examined - Tanzania, Usambara, Kombolo-Waldbestände, on decayed wood, February 1893, C. Holst (S-F12537, holotype); ibid. (S-F12538, isotype).

Known hosts and distribution - on decayed wood in India, Kenya and Tanzania (type locality) (Engler 1895, Subramanian \& Sekar 1990, Mugambi \& Huhndorf 2010). 
Notes - Euacanthe usambarensis was introduced based on Meliolopsis usambarensis (Theissen 1917). Nannfeldt \& Santesson (1975) proposed that Sphaeria foveolata and E. usambarensis were synonym of Acanthonitschkea foveolata. Later, Subramanian \& Sekar (1990) accepted E. foveolata as type species based on A. foveolata, and Mugambi \& Huhndorf (2010) sequenced E. foveolata (GKM1221). However, we use the original E. usambarensis as its generic type. This species is sister to the asexual species Pseudocatenomycopsis rothmanniae (0.97BY, Fig. 1) in Scortechiniaceae based on phylogenetic result.

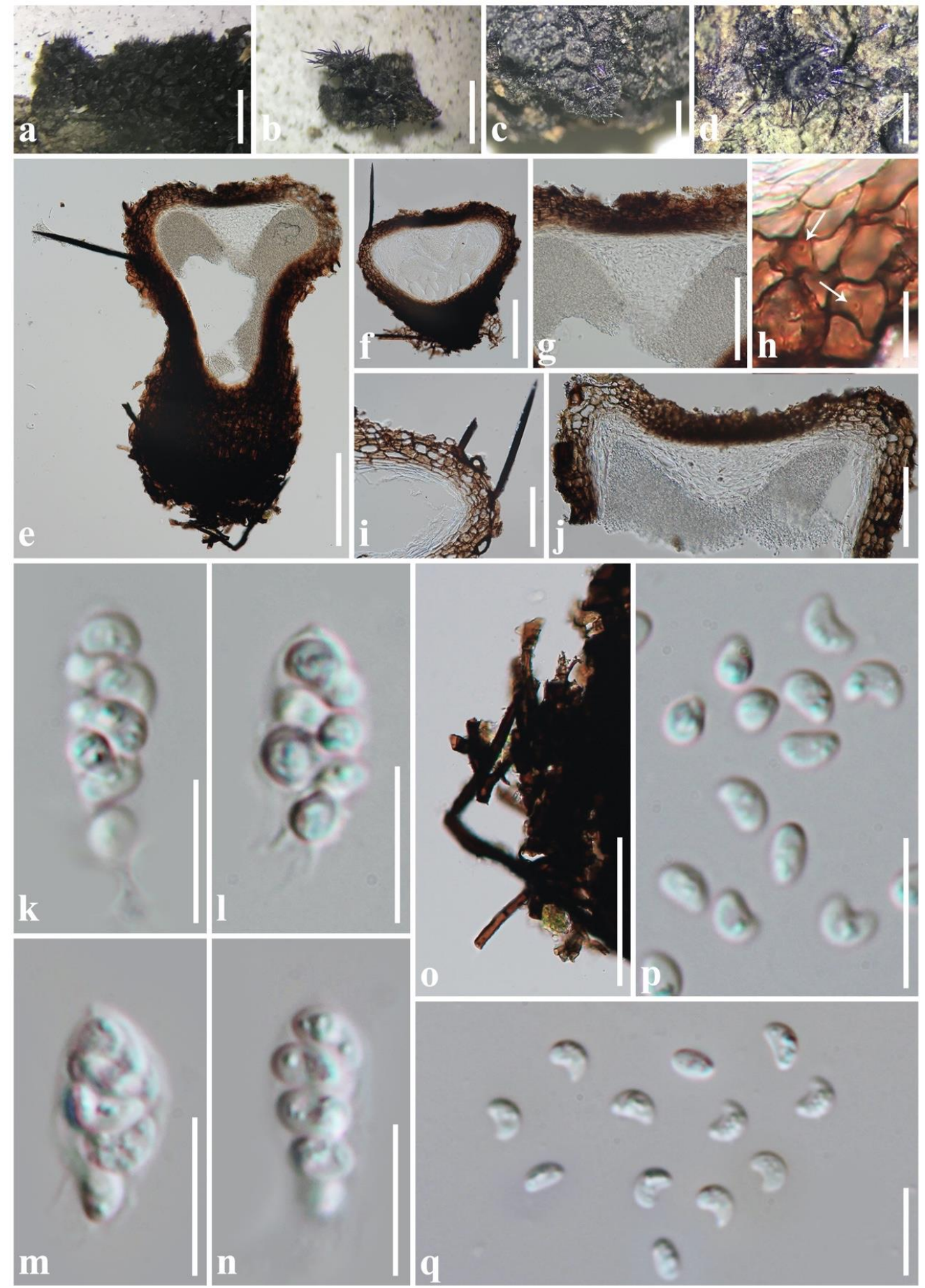

Figure 22 - Euacanthe usambarensis: a-b, f, h-j, m-n, q (S-F12537, holotype); c-e, g, k-1, o-p (SF12538, isotype). a-d Ascomata sitting on a subiculum on host. e-f Ascoma cross section. g, j Conical Quellkörper. h Munk pores (arrow). i Peridium. k-n Asci. o Septate hyphae. p-q Ascospores. Scale bars: $\mathrm{a}=2 \mathrm{~mm}, \mathrm{~b}-\mathrm{c}=1 \mathrm{~mm}, \mathrm{~d}=500 \mu \mathrm{m}, \mathrm{e}-\mathrm{f}=200 \mu \mathrm{m}, \mathrm{g}, \mathrm{i}-\mathrm{j}, \mathrm{o}=100 \mu \mathrm{m}$, $\mathrm{h}=20 \mu \mathrm{m}, \mathrm{k}-\mathrm{n}, \mathrm{p}-\mathrm{q}=10 \mu \mathrm{m}$. 
Neocryptosphaerella S.K. Huang \& K.D. Hyde, gen. nov.

Etymology: Name refers to genus being similar to Cryptosphaerella.

Facesoffungi number: FoF 10165; Index Fungorum number: IF558354

Saprobic on wood. Sexual morph: Ascomata solitary or scattered, immersed to erumpent, black, turbinate, the apex collapsing when dry, tuberculate, sitting in a subiculum, lacking ostioles, with a central, conical Quellkörper. Peridium composed of brown to hyaline cells of textura angularis to textura prismatica, Munk pores present. Paraphyses absent. Asci polysporous, unitunicate, clavate, with long pedicel, apex rounded, without apical ring, evanescent. Ascospores overlapping, hyaline, allantoid to cylindrical, slightly curved, aseptate, smooth-walled, guttulate. Asexual morph: Undetermined (adapted from Mugambi \& Huhndorf 2010).

Notes - We establish Neocryptosphaerella based on Cryptosphaerella celata (type) and $C$. globosa. Mugambi \& Huhndorf (2010) introduced six 'Cryptosphaerella' species having ascomata lacking ostioles and a Quellkörper. The characteristics of the type of Cryptosphaerella are ostiolate ascomata lacking a Quellkörper (Saccardo 1882a) (see notes for Cryptosphaerella). Therefore, Cryptosphaerella should not belong to Scortechiniaceae and these six species do not belong to Cryptosphaerella based on morphology. Phylogenetically, C. celata and C. globosa form an independent clade and the remaining four species form another clade in Scortechiniaceae (Mugambi \& Huhndorf 2010). The phylogenetic position of the type of Cryptosphaerella is undetermined. We therefore introduce Neocryptosphaerella for C. celata and C. globosa. This genus is sister to Biciliospora, Coronophorella, Pseudocryptosphaerella, Scortechiniella and Scortechiniellopsis in Scortechiniaceae, and has ascomata lacking ostioles, Quellkörper and polysporous asci with allantoid to cylindrical ascospores (Mugambi \& Huhndorf 2010, this study, 0.98BY, Fig. 1).

Neocryptosphaerella celata (Mugambi \& Huhndorf) S.K. Huang \& K.D. Hyde, comb. nov.

Basionym - Cryptosphaerella celata Mugambi \& Huhndorf, Mycologia 102(1): 197 (2010)

Facesoffungi number: FoF 10166; Index Fungorum number: IF558348

Saprobic on wood. Sexual morph: Ascomata solitary or scattered, immersed to erumpent, black, turbinate, the apex collapsing when dry, tuberculate, sitting in a subiculum, lacking ostioles, with a central, conical Quellkörper. Peridium composed of brown to hyaline cells of textura angularis to textura prismatica, Munk pores present. Paraphyses absent. Asci polysporous, unitunicate, clavate, with long pedicel, apex rounded, without apical ring, evanescent. Ascospores overlapping, hyaline, allantoid to cylindrical, slightly curved, aseptate, smooth-walled, guttulate. Asexual morph: Undetermined (adapted from Mugambi \& Huhndorf 2010).

Known hosts and distribution - on decorticated wood in Kenya (type locality) (Mugambi \& Huhndorf 2010).

Notes - Neocryptosphaerella celata is sister to N. globosa (84\%ML/1.00BY, Fig. 1), differing in the size of ascospores (Mugambi \& Huhndorf 2010).

Neocryptosphaerella globosa (Mugambi \& Huhndorf) S.K. Huang \& K.D. Hyde, comb. nov.

Basionym - Cryptosphaerella globosa Mugambi \& Huhndorf, Mycologia 102(1): 201 (2010) Index Fungorum number: IF558353

Neofracchiaea Teng, Sinensia, Shanghai 9: 255 (1938)

Saprobic on wood. Sexual morph: Subiculum composed of numerous, brown to dark brown, branched, septate hyphae, with dichotomously branched, rounded ends. Ascomata densely gregarious, superficial, sitting in a subiculum, coriaceous, black, globose to subglobose, the apex collapsing when dry, tuberculate, lacking ostioles, with a central, conical Quellkörper. Peridium composed of membranaceous, brown to hyaline cells of textura angularis to textura prismatica, Munk pores present. Paraphyses absent. Asci polysporous, arising from a hyaline placenta-like tissue, radially extending into the locule around the Quellkörper from the base, unitunicate, clavate, pedicellate, apex rounded, without apical ring, evanescent. Ascospores overlapping, hyaline, 
cylindrical to oblong, slightly curved, aseptate, smooth-walled, guttulate. Asexual morph: Undetermined (adapted from Saccardo 1882b).

Notes - The monotypic Neofracchiaea was introduced by Teng (1938) based on Cucurbitaria callista, which was considered to be a member of Cryptosphaerella, Fracchiaea or Nitschkia based on similar charcteristics (Saccardo 1882a, Fitzpatrick 1924, Nannfeldt \& Santesson 1975). However, Neofracchiaea nested in Scortechiniaceae as an independent clade based on phylogenetic results (Huhndorf et al. 2004b, Mugambi \& Huhndorf 2010). In this study, Neofracchiaea is sister to Scortechinia and Tympanopsis (Fig. 1).

Neofracchiaea callista (Berk. \& M.A. Curtis) Teng, Sinensia, Shanghai 9: 255 (1938)

Fig. 23

Basionym - Cucurbitaria callista Berk. \& M.A. Curtis, N. Amer. Fung.: no. 821 (1875)

Facesoffungi number: FoF 10068

Saprobic on wood. Sexual morph: Subiculum composed of numerous, brown to dark brown, branched, septate hyphae 3-7 $\mu \mathrm{m}$ wide, with dichotomously branched, rounded ends. Ascomata 200-350 $\mu \mathrm{m}(\bar{x}=260 \mu \mathrm{m}, \mathrm{n}=20)$ diam., densely gregarious, superficial, sitting in a subiculum, coriaceous, black, globose to subglobose, the apex collapsing when dry, tuberculate, lacking ostioles, with a central, conical Quellkörper. Peridium 20-55 $\mu \mathrm{m}$ wide, membranaceous, comprising two layers, outer layer composed of brown to olivaceous brown cells of textura angularis, Munk pores present; inner layer composed of hyaline cells of textura prismatica. Paraphyses absent. Asci (30-)40-50(-60) $\times(9-) 12-15(-18) \mu \mathrm{m}(\bar{x}=45 \times 14 \mu \mathrm{m}, \mathrm{n}=20)$ at ascospore-bearing part, polysporous, arising from a hyaline placenta-like tissue, radially extending into the locule around the Quellkörper from the base, unitunicate, clavate, pedicellate, apex rounded, without apical ring, evanescent. Ascospores $(5.5-) 6.5-8(-10) \times 1.5-2.6 \mu \mathrm{m}(\bar{x}=7.5 \times 2$ $\mu \mathrm{m}, \mathrm{n}=50$ ), overlapping, hyaline, cylindrical to oblong, slightly curved, aseptate, smooth-walled, guttulate. Asexual morph: Undetermined.

Material examined - USA, Maryland, Beltsville, on decayed wood, October 1950, F. Petrak (PDD-54147); ibid. 16 June 1950 (PDD-60976).

Known hosts and distribution - on decayed wood in China and the USA (type locality) (Berkeley 1875, Saccardo 1882a, Teng 1938).

Notes - We were unable to obtain type material and therefore, re-examined the authentic samples collected by Petrak from the USA.

Pseudocatenomycopsis Crous \& L.A. Shuttlew., in Crous et al., Persoonia 31: 221 (2013)

Saprobic on wood. Sexual morph: Undetermined. Asexual morph: Mycelium hyaline, branched, septate. Conidiophores erect, hyaline to brown, straight to flexuous, branched, septate. Conidiogenous cells hyaline to brown, subcylindrical, with flattened. Ramoconidia hyaline to brown, 0-1-septate, ellipsoidal to subcylindrical, smooth-walled, forming conidial chains. Conidia hyaline, ellipsoidal to ovoid, smooth-walled (adapted from Crous et al. 2013).

Notes - The monotypic Pseudocatenomycopsis was introduced for P. rothmanniae (Crous et al. 2013). This asexual genus is considered to be similar to Catenomycopsis in morphology and in phylogenetic position is sister to Euacanthe (Crous et al. 2013, this study, Fig. 1).

Pseudocatenomycopsis rothmanniae Crous \& L.A. Shuttlew., in Crous et al., Persoonia 31: 221 (2013)

Facesoffungi number: FoF 10167

Saprobic on wood. Sexual morph: Undetermined. Asexual morph: Mycelium hyaline, branched, septate. Conidiophores erect, hyaline to brown, straight to flexuous, branched, septate. Conidiogenous cells hyaline to brown, subcylindrical, with flattened. Ramoconidia hyaline to brown, 0-1-septate, ellipsoidal to subcylindrical, smooth-walled, forming conidial chains. Conidia hyaline, ellipsoidal to ovoid, smooth-walled (adapted from Crous et al. 2013).

Known hosts and distribution - on stems of Rothmannia engleriana (Rubiaceae) in Zambia (type locality) (Crous et al. 2013). 
Notes - Pseudocatenomycopsis rothmanniae is sister to Euacanthe usambarensis (0.97BY, Fig. 1)
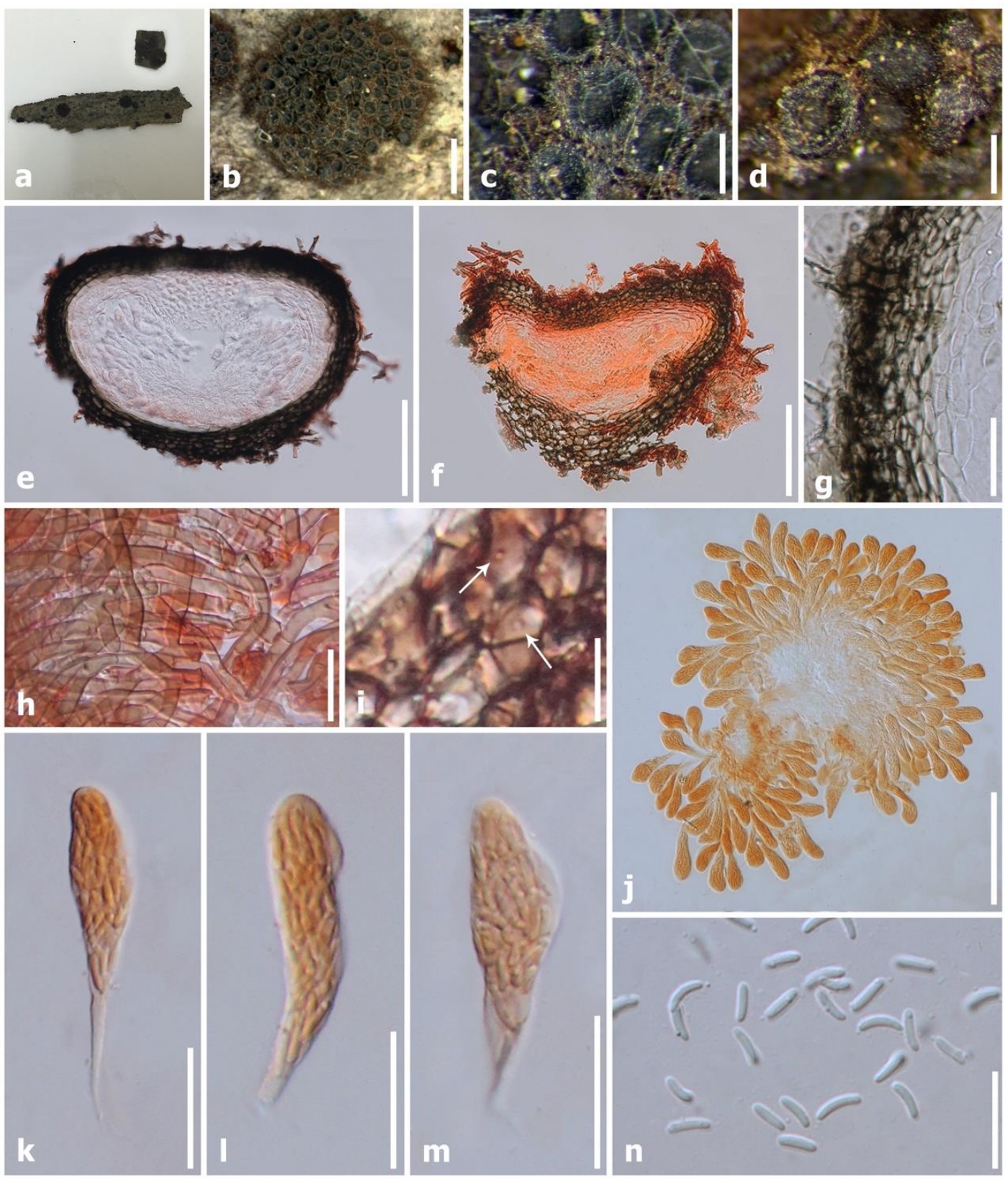

Figure 23 - Neofracchiaea callista: a-c, e, h-j, i, n (PDD-54147); d, f-h, j-m (PDD-60976). a Material. b-d Ascomata sitting in a subiculum on host. e-f Ascoma cross section. g Peridium. h Septate hyphae. i Munk pores (arrow). j-m Asci. n Ascospores. Notes: e-f, h, j-m are stained in Congo red reagent. Scale bars: $b=1 \mathrm{~mm}, \mathrm{c}-\mathrm{d}=200 \mu \mathrm{m}, \mathrm{e}-\mathrm{f}, \mathrm{j}=100 \mu \mathrm{m}, \mathrm{g}-\mathrm{h}, \mathrm{k}-\mathrm{n}=20 \mu \mathrm{m}, \mathrm{i}=10$ $\mu \mathrm{m}$.

Pseudocryptosphaerella S.K. Huang \& K.D. Hyde, gen. nov.

Etymology: Name refers to genus being similar to Cryptosphaerella.

Facesoffungi number: FoF 10168; Index Fungorum number: IF558359

Saprobic on wood. Sexual morph: Ascomata solitary or scattered, immersed to erumpent, black, turbinate, the apex collapsing when dry, tuberculate, sitting in a subiculum, lacking ostioles, with a central, conical Quellkörper. Peridium composed of brown to hyaline cells of textura angularis to textura prismatica, Munk pores present. Paraphyses absent. Asci 8- to multi-spored, unitunicate, clavate, with long pedicel, apex rounded, without apical ring, evanescent. Ascospores 
overlapping, hyaline, ellipsoidal cylindrical to broadly fusiform, slightly curved, aseptate, smoothwalled, guttulate. Asexual morph: Undetermined (adapted from Mugambi \& Huhndorf 2010).

Notes - Mugambi \& Huhndorf (2010) introduced and sequenced four 'Cryptosphaerella' species, C. costaricensis, C. cylindriformis, C. elliptica and C. malindensis. These species clustered in a clade and are characterized by lacking ostioles in the ascomata and a Quellkörper, polysporous asci and ellipsoidal to broadly fusiform ascospores (Mugambi \& Huhndorf 2010). In this study, they cluster with 100\%ML/1.00BY support (Fig. 1) and are sister to Biciliospora, Scortechiniella and Scortechiniellopsis in Scortechiniaceae. Therefore, we accept these species as members of Pseudocryptosphaerella based on phylogenetic result.

Pseudocryptosphaerella elliptica (Mugambi \& Huhndorf) S.K. Huang \& K.D. Hyde, comb. nov. Basionym - Cryptosphaerella elliptica Mugambi \& Huhndorf, Mycologia 102(1): 201 (2010) Facesoffungi number: FoF 10169; Index Fungorum number: IF558355

Saprobic on wood. Sexual morph: Ascomata solitary or scattered, immersed to erumpent, black, turbinate, the apex collapsing when dry, tuberculate, with tooth-like setae, sitting in a subiculum, lacking ostioles, with a central, conical Quellkörper. Peridium composed of brown to hyaline cells of textura angularis to textura prismatica, Munk pores present. Paraphyses absent. Asci polysporous, unitunicate, clavate, with long pedicel, apex rounded, without apical ring, evanescent. Ascospores overlapping, hyaline, ellipsoidal to broadly fusiform, aseptate, smoothwalled, guttulate. Asexual morph: Undetermined (adapted from Mugambi \& Huhndorf 2010).

Known hosts and distribution - on decayed wood in Ecuador (type locality) (Mugambi \& Huhndorf 2010).

Notes - Pseudocryptosphaerella elliptica is sister to P. cylindriformis (100\% ML/1.00BY, Fig. 1), differing from the latter which has cylindrical to oblong ascospores.

Pseudocryptosphaerella costaricensis (Mugambi \& Huhndorf) S.K. Huang \& K.D. Hyde, comb. nov. (2010)

Basionym - Cryptosphaerella costaricensis Mugambi \& Huhndorf, Mycologia 102(1): 199

Index Fungorum number: IF558356

Pseudocryptosphaerella cylindriformis (Mugambi \& Huhndorf) S.K. Huang \& K.D. Hyde, comb. nov. (2010)

Basionym - Cryptosphaerella cylindriformis Mugambi \& Huhndorf, Mycologia 102(1): 199

Index Fungorum number: IF558357

Pseudocryptosphaerella malindensis (Mugambi \& Huhndorf) S.K. Huang \& K.D. Hyde, comb. nov.

Basionym - Cryptosphaerella malindensis Mugambi \& Huhndorf [as 'malindensis'], Mycologia 102(1): 202 (2010)

Index Fungorum number: IF558358

Scortechinia Sacc., Syll. fung. (Abellini) 9: 604 (1891)

Saprobic on wood. Sexual morph: Subiculum composed of numerous, brown to dark brown, branched, septate hyphae, with dichotomously branched, spinous ends. Ascomata densely gregarious, superficial, sitting in a subiculum, carbonaceous, black, with metallic iridescence, turbinate, globose to subglobose, the apex collapsing when dry, glabrous, lacking ostioles, with a central, conical Quellkörper. Peridium composed of membranaceous, brown to hyaline cells of textura angularis to textura prismatica, Munk pores present. Paraphyses absent. Asci 8-spored, arising from a hyaline placenta-like tissue, radially extending into the locule around the Quellkörper from the base, unitunicate, clavate, pedicellate, apex rounded, without apical ring, evanescent. Ascospores bi-seriate to overlapping, hyaline to brown, ellipsoidal to oval, straight or 
curved, aseptate, smooth-walled, guttulate. Asexual morph: Undetermined (adapted from Subramanian \& Sekar 1990).

Notes - Scortechinia was introduced by Saccardo \& Berlese (1885) for S. culcitella. This genus subsequently was considered as a synonym of Nitschkia based on similar morphology (Nannfeldt \& Santesson 1975). However, S. acanthostroma, S. conferta and S. diminuspora were sequenced by Huhndorf et al. (2004b) and Mugambi \& Huhndorf (2010). These strains are sister to Tympanopsis in Scortechiniaceae (Fig. 1). Subramanian \& Sekar (1990) combined Tympanopsis confertula as Scortechinia conferta based on their similar characteristics, which is also confirmed by molecular analysis (Fig. 1).

Scortechinia culcitella (Berk. \& Ravenel) Speg., Anal. Soc. cient. argent. 26(1): 29 (1888)

Fig. 24a-m

Basionym - Sphaeria culcitella Berk. \& Ravenel, in Berkeley \& Curtis, Proc. Amer. Acad. Arts \& Sci. 4: 128 (1860)

Facesoffungi number: FoF 10170

Saprobic on wood. Sexual morph: Subiculum composed of numerous, brown to dark brown, branched, septate hyphae 6.5-14 $\mu \mathrm{m}$ wide, with dichotomously branched, spinous ends. Ascomata $220-400 \times 140-260 \mu \mathrm{m}(\bar{x}=300 \times 220 \mu \mathrm{m}, \mathrm{n}=10)$, densely gregarious, superficial, sitting in a subiculum, carbonaceous, black, with metallic iridescence, turbinate, globose to subglobose, the apex collapsing when dry, glabrous, lacking ostioles, with a central, conical Quellkörper. Peridium 30-75 $\mu \mathrm{m}$ wide, composed of membranaceous, brown to hyaline cells of textura angularis to textura prismatica, Munk pores present. Paraphyses absent. Asci 8-spored, arising from a hyaline placenta-like tissue, radially extending into the locule around the Quellkörper from the base, unitunicate, clavate, pedicellate, apex rounded, without apical ring, evanescent. Ascospores $9-13 \times$ 4-5 $\mu \mathrm{m}(\bar{x}=11 \times 4.5 \mu \mathrm{m}, \mathrm{n}=20)$, bi-seriate to overlapping, hyaline to brown, ellipsoidal to oval, straight or curved, aseptate, smooth-walled, guttulate. Asexual morph: Undetermined (adapted from Spegazzini 1888).

Material examined - USA, Carolina, on decayed trunk of Ostrya or Acer (PC-MNHN-PCPC0121050).

Known hosts and distribution - on decayed wood of Betula, Cerasus and Prunus in India, Paraguay (type locality) and the USA (Spegazzini 1888, Subramanian \& Sekar 1990).

Notes - Scortechinia culcitella was introduced based on Sphaeria culcitella (Spegazzini 1888). Nannfeldt \& Santesson (1975) subsequently transferred it as Nitschkia acanthostroma (= S. acanthostroma) based on morphology. Scortechinia acanthostroma was sequenced by Mugambi \& Huhndorf (2010), but there is no molecular data available for the type S. culcitella.

Scortechiniella Arx \& E. Müll., Beitr. Kryptfl. Schweiz 11(no. 1): 382 (1954)

Saprobic on wood. Sexual morph: Subiculum composed of numerous, brown to dark brown, branched, septate hyphae, with dichotomously branched, rounded ends. Ascomata scattered or gregarious, superficial, sitting in a subiculum, coriaceous, brown to black, globose to subglobose, the apex collapsing when dry, glabrous, lacking ostioles, with a central, conical Quellkörper at apex. Peridium composed of membranaceous, brown to hyaline cells of textura angularis to textura prismatica. Paraphyses absent. Asci polysporous, arising from a hyaline placenta-like tissue, radially extending into the locule around the Quellkörper from the base, unitunicate, clavate, pedicellate, apex rounded, without apical ring, evanescent. Ascospores overlapping, hyaline, ellipsoidal to oval, aseptate, smooth-walled, guttulate, with a filiform appendage at each end. Asexual morph: Undetermined (adapted from von Arx \& Müller 1954).

Notes - The monotypic Scortechiniella was introduced for S. similis which has similar morphology to Scortechinia, differing in multi-spored asci and ascospores with appendages (von Arx \& Müller 1954). Mugambi \& Huhndorf (2010) accepted it as a member of Scortechiniaceae based on its molecular data. In this study, Scortechiniella is sister to Biciliospora (85\% ML/1.00BY, Fig. 1). However, the latter has fusiform ascospores. 

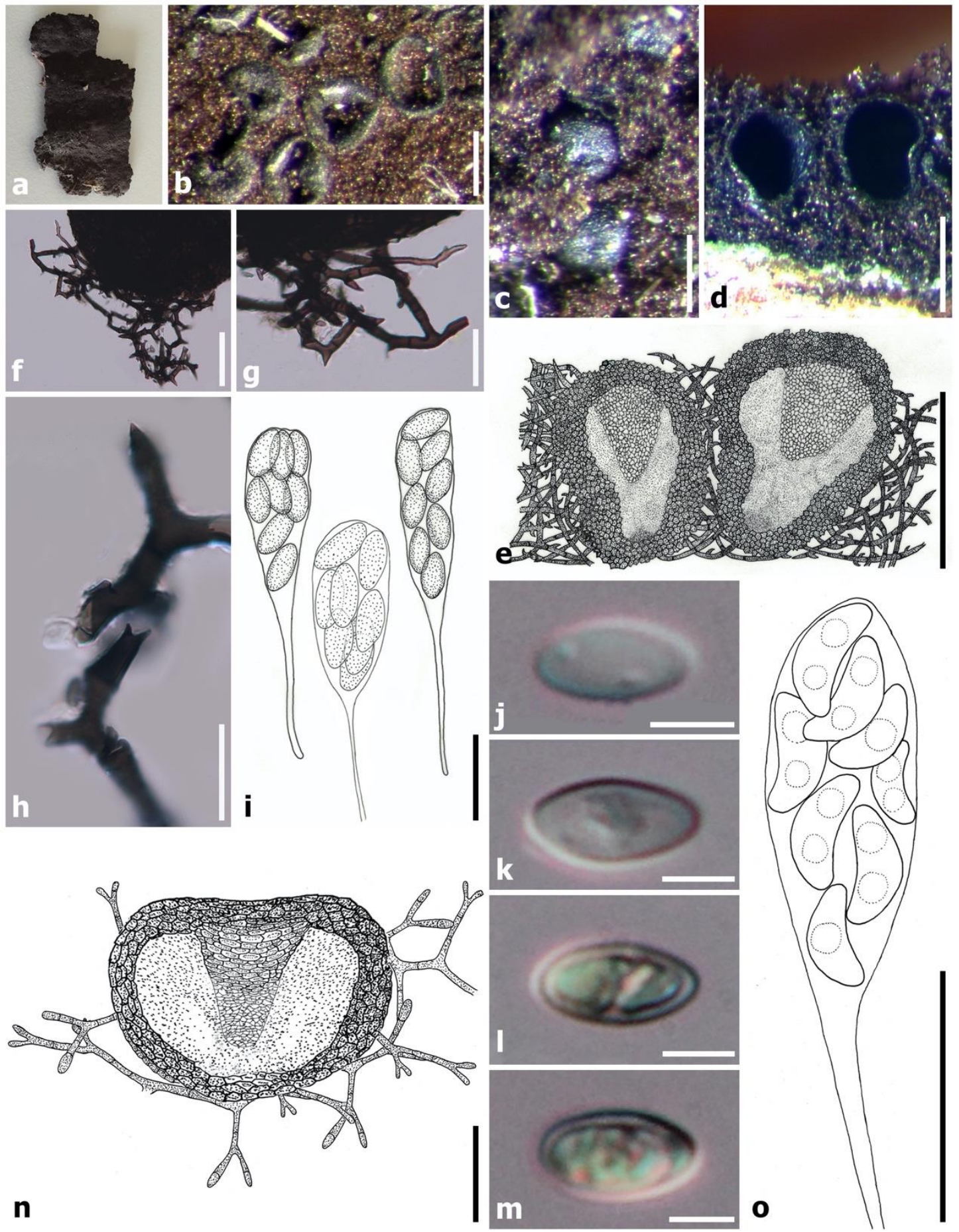

Figure 24 - Scortechinia culcitella: a-h, j-m (PC-MNHN-PC-PC0121050); i (redrawn from Subramanian \& Sekar 1990). a Material. b-d Gregarious ascomata sitting in a subiculum. e Sectional view of Ascomata. $\mathrm{f}-\mathrm{h}$ Hyphae of subiculum. i Asci. j-m Ascospores; Coronophorella chaetomioides: $\mathrm{n}-\mathrm{o}$ (redrawn from Subramanian \& Sekar 1990). n Sectional view of Ascoma. o Ascus. Scale bars: $\mathrm{b}-\mathrm{e}=200 \mu \mathrm{m}, \mathrm{f}, \mathrm{n}=100 \mu \mathrm{m}, \mathrm{g}-\mathrm{h}=50 \mu \mathrm{m}, \mathrm{o}=20 \mu \mathrm{m}, \mathrm{i}=10 \mu \mathrm{m}, \mathrm{j}-\mathrm{m}=5$ $\mu \mathrm{m}$.

Scortechiniella similis (Bres.) Arx \& E. Müll., Beitr. Kryptfl. Schweiz 11(no. 1): 383 (1954)

Fig. 251-n

Basionym - Trichosphaerella similis Bres., in Wildeman, Bull. Jard. bot. État Brux. 4(1): 7 (1914)

Facesoffungi number: FoF 10171 
Saprobic on wood. Sexual morph: Subiculum composed of numerous, brown to dark brown, branched, septate hyphae, with dichotomously branched, rounded ends. Ascomata scattered or gregarious, superficial, sitting in a subiculum, coriaceous, brown to black, globose to subglobose, the apex collapsing when dry, glabrous, lacking ostioles, with a central, conical Quellkörper at apex. Peridium composed of membranaceous, brown to hyaline cells of textura angularis to textura prismatica. Paraphyses absent. Asci polysporous, arising from a hyaline placenta-like tissue, radially extending into the locule around the Quellkörper from the base, unitunicate, clavate, pedicellate, apex rounded, without apical ring, evanescent. Ascospores overlapping, hyaline, ellipsoidal to oval, aseptate, smooth-walled, guttulate, with a filiform appendage at each end. Asexual morph: Undetermined (adapted from von Arx \& Müller 1954).

Known hosts and distribution - on decayed wood in Puerto Rico and Zaire (type locality) (von Arx \& Müller 1954, Mugambi \& Huhndorf 2010).

Notes - Scortechiniella similis is similar to Biciliospora velutina in having ascomata without ostioles, polysporous asci and ascospores with filiform appendages, but the latter has fusiform ascospores. Phylogenetically, $S$. similis is sister to $B$. velutina based on multi-gene analysis (85\% ML/1.00BY, Fig. 1).

Scortechiniellopsis Sivan., Trans. Br. mycol. Soc. 62(1): 36 (1974)

Saprobic on wood. Sexual morph: Subiculum composed of numerous, brown to dark brown, branched, septate hyphae, with dichotomously branched, tapering ends. Ascomata scattered or gregarious, superficial, sitting in a subiculum, coriaceous, brown to black, globose to subglobose, the apex collapsing when dry, glabrous, lacking ostioles, with a central, conical Quellkörper at apex, almost or touching the bottom of the locule. Peridium composed of membranaceous, brown to hyaline cells of textura angularis to textura prismatica. Paraphyses filiform. Asci polysporous, arising from a hyaline placenta-like tissue, radially extending into the locule around the Quellkörper from the base, unitunicate, clavate to cylindrical, pedicellate, apex rounded, without apical ring, evanescent. Ascospores overlapping, hyaline, reniform, allantoid to ovoid, aseptate, smooth-walled, guttulate. Asexual morph: Undetermined (adapted from Sivanesan 1974).

Notes - The monotypic Scortechiniellopsis was initially placed in Coronophorales (Sivanesan 1974). However, Mugambi \& Huhndorf (2010) accepted it in Scortechiniaceae based on phylogenetic result. In this study, Scortechiniellopsis is sister to Biciliospora and Scortechiniella (83\% ML/1.00BY, Fig. 1), differing from it in the possessing of ascospores without appendage.

Scortechiniellopsis leonensis Sivan., Trans. Br. mycol. Soc. 62(1): 37 (1974)

Fig. 25a-f

Facesoffungi number: FoF 10172

Saprobic on wood. Sexual morph: Subiculum composed of numerous, brown to dark brown, branched, septate hyphae, with dichotomously branched, tapering ends. Ascomata scattered or gregarious, superficial, sitting in a subiculum, coriaceous, brown to black, globose to subglobose, the apex collapsing when dry, glabrous, lacking ostioles, with a central, conical Quellkörper at apex, almost or touching the bottom of the locule. Peridium composed of membranaceous, brown to hyaline cells of textura angularis to textura prismatica. Paraphyses filiform. Asci polysporous, arising from a hyaline placenta-like tissue, radially extending into the locule around the Quellkörper from the base, unitunicate, clavate to cylindrical, pedicellate, apex rounded, without apical ring, evanescent. Ascospores overlapping, hyaline, reniform, allantoid to ovoid, aseptate, smooth-walled, guttulate. Asexual morph: Undetermined (adapted from Sivanesan 1974).

Material examined - Sierra Leone, on decayed branch of Cynometra leonensis, 27 September 1954, F.C. Deighton (IMI-58117, holotype).

Known hosts and distribution - on decayed wood of Cynometra leonensis (Fabaceae) in Sierra Leone (type locality) and Kenya (Mugambi \& Huhndorf 2010).

Notes - We re-examined the holotype specimen. Unfortunately, we did not find any structures, except for some dark brown and septate hyphae. 


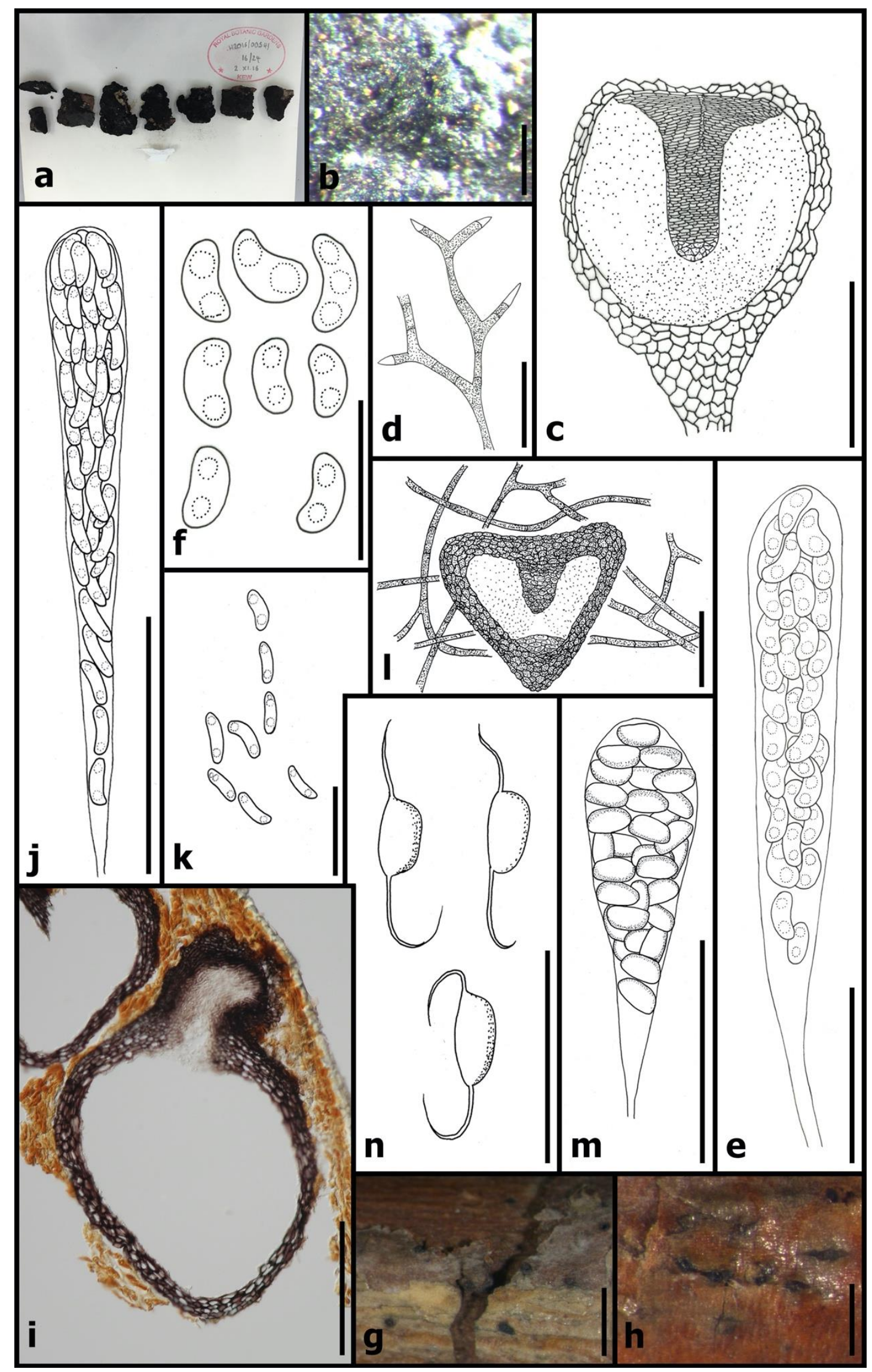

Figure 25 - Scortechiniellopsis leonensis: a-b (IMI-58117, holotype); c-f (redrawn from Sivanesan 1974). a Material. b Hyphae on host. c Sectional view of Ascoma. d Hyphae of subiculum. e Ascus. f Ascospores; Cryptosphaerella nitschkei: g (IMI-K-M251354); h-i (NY02934200); j-k (redrawn from Saccardo 1882b). g-h Immersed ascomata. i Ascoma cross section. 
j Ascus. k Ascospores; Scortechiniella similis: 1-n (redrawn from von Arx \& Müller 1954). 1 Sectional view of ascoma. $\mathrm{m}$ Ascus. $\mathrm{n}$ Ascospores. Scale bars: $\mathrm{g}=1 \mathrm{~mm}, \mathrm{~h}=500 \mu \mathrm{m}, \mathrm{b}-\mathrm{c}, \mathrm{i}, \mathrm{l}=$ $200 \mu \mathrm{m}, \mathrm{d}, \mathrm{j}, \mathrm{m}=50 \mu \mathrm{m}, \mathrm{e}, \mathrm{k}, \mathrm{n}=20 \mu \mathrm{m}, \mathrm{f}=10 \mu \mathrm{m}$.

Tympanopsis Starbäck, Bih. K. svenska VetenskAkad. Handl., Afd. 3 19(no. 2): 24 (1894)

Saprobic on wood. Sexual morph: Subiculum composed of numerous, brown to dark brown, branched, septate hyphae. Ascomata scattered to gregarious, superficial, sitting in a subiculum, carbonaceous to coriaceous, black, turbinate, globose to subglobose, the apex collapsing when dry, tuberculate, glabrous, lacking ostioles, with a central, conical Quellkörper. Peridium usually outer layer composed of carbonaceous, black tissue; inner layer composed of membranaceous, brown to hyaline cells of textura angularis to textura prismatica, sometimes Munk pores present. Paraphyses absent. Asci 8-spored, arising from a hyaline placenta-like tissue, radially extending into the locule around the Quellkörper from the base, unitunicate, clavate, pedicellate, apex rounded, without apical ring, evanescent. Ascospores bi-seriate to overlapping, hyaline to brown or olivaceous brown, ellipsoidal to oval, straight or curved, aseptate, smooth-walled, guttulate. Asexual morph: Undetermined (adapted from Starbäck 1894).

Notes - Tympanopsis was introduced by Starbäck (1894) for T. euomphala. Nannfeldt \& Santesson (1975) subsequently accepted it as Nitschkia. However, the phylogenetic position of $T$. uniseriate is an independent clade in Scortechiniaceae (Mugambi \& Huhndorf 2010). In this study, Tympanopsis is sister to Scortechinia (Fig. 1).

Tympanopsis euomphala (Berk. \& M.A. Curtis) Starbäck, Bih. K. svenska VetenskAkad. Handl., Afd. 3 19(no. 2): 24 (1894)

Fig. 26

Basionym - Sphaeria euomphala Berk. \& M.A. Curtis, Grevillea 4(no. 32): 141 (1876)

Facesoffungi number: FoF 10069

Saprobic on wood. Sexual morph: Subiculum composed of numerous, brown to dark brown, branched, septate hyphae 4-8 $\mu \mathrm{m}$ wide, with rounded ends. Ascomata 390-700 $\times 400-600 \mu \mathrm{m}(\bar{x}=$ $580 \times 480 \mu \mathrm{m}, \mathrm{n}=10$ ), scattered to gregarious, superficial, sitting in a subiculum, carbonaceous to coriaceous, black, turbinate, globose to subglobose, the apex collapsing when dry, tuberculate, glabrous, lacking ostioles, with a central, conical Quellkörper. Peridium 40-130 $\mu \mathrm{m}$ wide, comprising three layers, outer layer composed of carbonaceous, black tissue; middle layer composed of membranaceous, brown to reddish-brown cells of textura angularis, Munk pore present; inner layer membranaceous, composed of hyaline cells of textura prismatica. Paraphyses absent. Asci $20-25 \times 8-12 \mu \mathrm{m}(\bar{x}=23 \times 10 \mu \mathrm{m}, \mathrm{n}=10)$ at ascospore-bearing part, 8 -spored, arising from a hyaline placenta-like tissue, radially extending into the locule around the Quellkörper from the base, unitunicate, clavate, pedicellate, apex rounded, without apical ring, evanescent. Ascospores 6-9 $\times 2.5-3.5 \mu \mathrm{m}(\bar{x}=7 \times 3 \mu \mathrm{m}, \mathrm{n}=50)$, bi-seriate to overlapping, hyaline to olivaceous brown, ellipsoidal, straight or slightly curved, aseptate, smooth-walled, guttulate. Asexual morph: Undetermined.

Material examined - UK, on decayed wood, associated with Hyporxylon rubiginosum, 26 September 1935, E.W. Mason (IMI-13384).

Known hosts and distribution - on decayed wood of Fraxinus in the UK and USA (type locality) (Berkeley 1876).

Notes - Tympanopsis euomphala was transferred as Nitschkia confertula (Nannfeldt \& Santesson 1975), but no molecular data is available. We were unable to obtain type material. Therefore, we re-examined an authentic material determined by Nannfeldt (mentioned in the label of material).

Hypocreales Lindau, in Engler \& Prantl, Nat. Pflanzenfam., Teil. I (Leipzig) 1(1): 343 (1897)

Notes - Hypocreales accommodates fourteen families, Bionectriaceae, Calcarisporiaceae, Clavicipitaceae, Cocoonihabitaceae, Cordycipitaceae, Flammocladiellaceae, Hypocreaceae, Myrotheciomycetaceae, Nectriaceae, Niessliaceae, Ophiocordycipitaceae, Sarocladiaceae, 
Stachybotryaceae, and Tilachlidiacea (Hyde et al. 2020e, Wijayawardene et al. 2020). They are widely distributed in tropical and subtropical regions as saprophytic, symbiotic or parasitic organisms (Maharachchikumbura et al. 2016, Hyde et al. 2020e). However, the multi-gene analysis proved that these families belong in Hypocreales, and they usually have membranaceous ascomata (Hyde et al. 2020e).
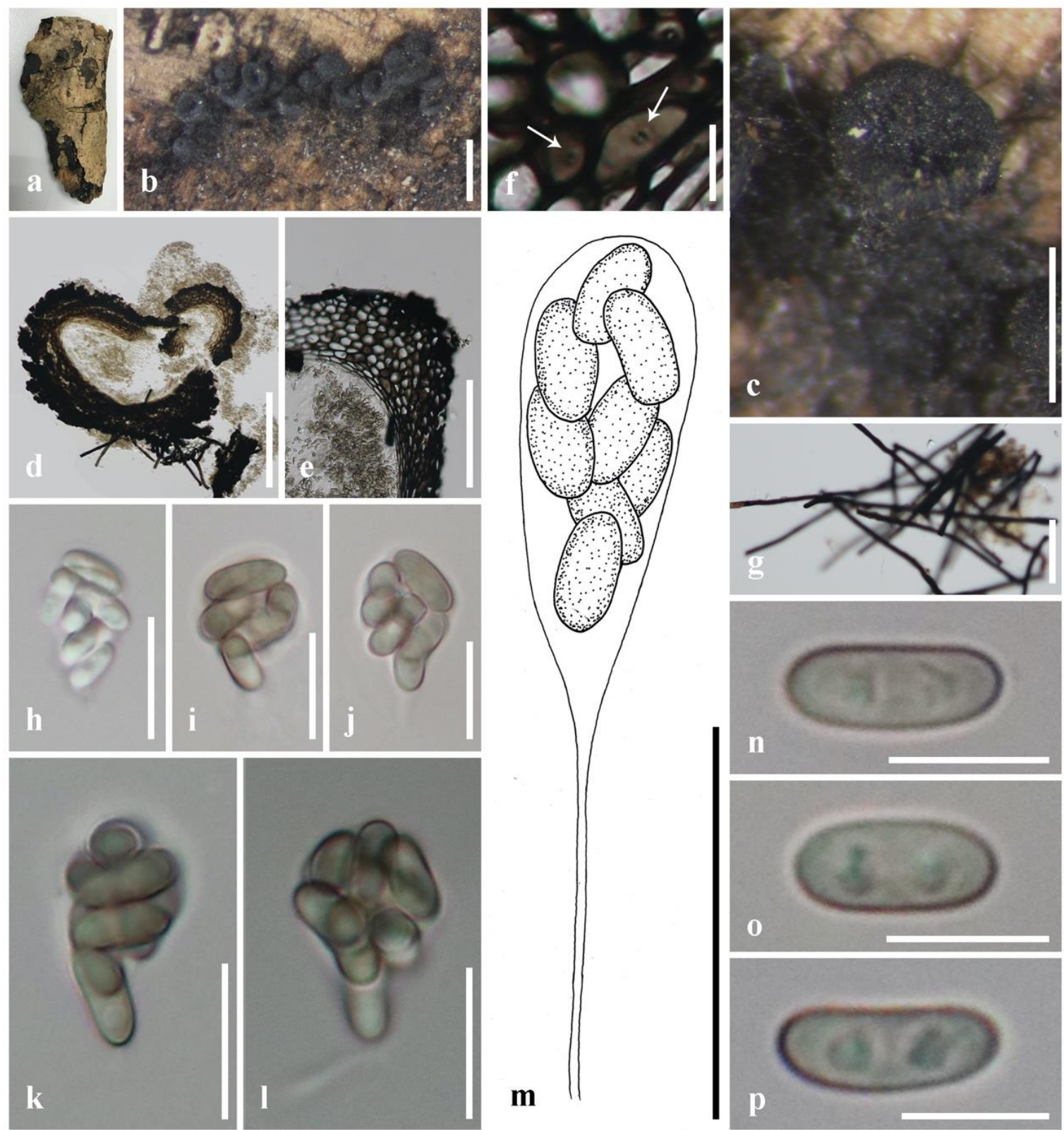

Figure 26 - Tympanopsis euomphala: a-1, n-p (IMI-13384); m (redrawn from Starbäck 1894). a Material. b-c Ascomata. d-e Ascoma cross section. f Munk pores (arrow). g Hyphae of subiculum. $\mathrm{h}-\mathrm{m}$ Asci. $\mathrm{n}-\mathrm{p}$ Ascospores. Scale bars: $\mathrm{b}=1 \mathrm{~mm}, \mathrm{c}=500 \mu \mathrm{m}, \mathrm{d}=200 \mu \mathrm{m}, \mathrm{e}, \mathrm{g}=100$ $\mu \mathrm{m}, \mathrm{m}=20 \mu \mathrm{m}, \mathrm{f}, \mathrm{h}-1=10 \mu \mathrm{m}, \mathrm{n}-\mathrm{p}=5 \mu \mathrm{m}$.

Niessliaceae Kirschst., Annls mycol. 37(1/2): 89 (1939)

Saprobic or parasitic on wood, leaves or isolated from soil, sometimes fungicolous and lichenicolous. Sexual morph: Ascomata perithecial or cleistothecial, solitary or gregarious, semiimmersed to superficial, sometimes sitting on a subiculum, cupuliform, globose to subglobose, yellow, orange, brown or black, membranaceous, tuberculate or smooth, glabrous or with setae or irregular appendages, collapsing or collapsing laterally or not collapsing, with or lacking ostioles. Peridium composed of membranaceous, yellow or brown or olivaceous brown or reddish brown to 
hyaline cells of textura angularis to textura epidermoidea to textura prismatica. Paraphyses absent or filiform or cylindrical, septate, branched or unbranched. Asci 8-spored, unitunicate, cylindrical to clavate, pedicellate, apex rounded or blunt, apical ring indistinct or absent, evanescent. Ascospores uni- or bi-seriate or overlapping, hyaline to brown, ellipsoidal to fusiform, straight or curved, 0-1septate, verrucose or smooth-walled, sometimes faintly striate, mostly with guttules. Asexual morph: Hyphomycetous. Mycelium hyaline to light brown, superficial, effused. Conidiophores mononematous, macronematous, hyaline, unbranched, aseptate. Conidia oval to ellipsoidal, usually aseptate, hyaline, smooth-walled, guttulate. Coelomycetous. Conidiomata globose to subglobose, dark brown to black. Peridium composed of brown cells of textura angularis, becoming hyaline towards the inner conidiogenous region. Conidiophores hyaline, cylindrical to subcylindrical, septate. Conidia oval to ellipsoidal, 0-2-septate, hyaline, smooth-walled, guttulate (adapted from Samuels \& Barr 1997, Hyde et al. 2020e).

Type genus - Niesslia Auersw.

Notes - The family Niessliaceae was established by Kirschstein (1939) to currently accommodate 21 genera (Hyde et al. 2020e, Wijayawardene et al. 2020). They usually have perithecial ascomata, unitunicate asci with inamyloid apical ring and hyaline, ellipsoidal to fusiform ascospores (Samuels \& Barr 1997, Hyde et al. 2020e). Eight genera have molecular data, Eucasphaeria, Myrtacremonium, Neoeucasphaeria, Niesslia, Pseudohyaloseta, Rosasphaeria, Trichosphaerella, Valetoniellopsis, and they are aggregated in Niessliaceae (Hyde et al. 2020e, this study, 83\%ML/1.00BY, Fig. 1).

Atronectria Etayo, in Etayo \& Rosato, Biblthca Lichenol. 98: 52 (2008)

Lichenicolous. Sexual morph: Ascomata perithecial, solitary or scattered, immersed to erumpent, pyriform to subglobose, black, membranaceous, tuberculate, glabrous, collapsing or collapsing laterally when dry, ostiolate, periphysate. Peridium composed of membranaceous, brown to hyaline cells of textura angularis to textura epidermoidea to textura prismatica. Paraphyses cylindrical, branched, septate, constricted at the septum. Asci 8-spored, unitunicate, cylindrical, pedicellate, apex blunt, apical ring indistinct, evanescent. Ascospores bi-seriate, hyaline to brown, oblong to ellipsoidal, straight or slightly curved, 1-septate, smooth-walled, guttulate. Asexual morph: Undetermined (adapted from Etayo \& Sancho 2008, Flakus et al. 2019).

Notes - The lichenicolous Atronectria was introduced by Etayo \& Sancho (2008) for A. magellanica. The second species, A. lobariellae, was collected on Lobariella crenulata from Bolivia (Flakus et al. 2019). These two species have perithecial ascomata, cylindrical asci and hyaline ascospores (Etayo \& Sancho 2008, Flakus et al. 2019), however no molecular data is available for the Atronectria.

Atronectria magellanica Etayo, in Etayo \& Sancho, Biblthca Lichenol. 98: 52 (2008) Fig. 27a-g Facesoffungi number: FoF 10173

Lichenicolous. Sexual morph: Ascomata perithecial, solitary or scattered, immersed to erumpent through the bark of host, pyriform to subglobose, black, membranaceous, tuberculate, glabrous, collapsing or collapsing laterally when dry, ostiolate, periphysate. Peridium composed of membranaceous, brown to hyaline cells of textura epidermoidea to textura prismatica. Paraphyses cylindrical, branched, septate, constricted at the septum. Asci 8-spored, unitunicate, cylindrical, pedicellate, apex blunt, apical ring indistinct, evanescent. Ascospores bi-seriate, hyaline to brown, ellipsoidal to fusiform, straight or slightly curved, 1-septate, constricted at the septum, smoothwalled, guttulate. Asexual morph: Undetermined (adapted from Etayo \& Sancho 2008).

Material examined - Chile, Navarino, Lago Róbalo, S5458'40.0”, W67 41'24.7’, c. 420m, on thallus of Pseudocyphellaria coriifolia on Nothofagus pumilio; 19 January 2005, J. Etayo (MAF-Etayo 22938, holotype).

Known hosts and distribution - on Pseudocyphellaria coriifolia that grow on Nothofagus in Chile (type locality) (Etayo \& Sancho 2008). 
Notes - We re-examined the holotype of Atronectria magellanica, but apart from the fragile ascomata, we did not observe other structures.

Circinoniesslia Samuels \& M.E. Barr, Can. J. Bot. 75(12): 2166 (1998) [1997]

Fungicolous, on ascomata of Bionectria or Nectria species. Sexual morph: Ascomata perithecial, solitary or scattered, superficial, globose, yellow, membranaceous, surrounded by white, circinately coiled appendages, collapsing when dry, ostiolate with an unconspicuous papilla, periphysate. Peridium composed of membranaceous, yellow to hyaline cells of textura globulosa to textura angularis to textura prismatica. Paraphyses absent. Asci 8-spored, unitunicate, cylindrical, pedicellate, apex rounded, evanescent. Ascospores bi-seriate, hyaline, ellipsoidal, straight or slightly curved, 1-septate, striate, guttulate. Asexual morph: Undetermined (adapted from Samuels \& Barr 1997).

Notes - The monotypic Circinoniesslia was found on ascomata of Bionectria or Nectria and has a special crown-shaped appendage on ascomata with striate ascospores (Samuels \& Barr 1997). Samuels \& Barr (1997) considered that the superficial and setose ascomata is the main feature of Niessliaceae, and Circinoniesslia meets this condition.

Circinoniesslia nectriae Samuels \& M.E. Barr, Can. J. Bot. 75(12): 2166 (1998) [1997] Fig. 28

Facesoffungi number: FoF 10070

Fungicolous, on ascomata of Bionectria or Nectria species. Sexual morph: Ascomata 260 $360 \mu \mathrm{m}(\bar{x}=300 \mu \mathrm{m}, \mathrm{n}=10)$ diam., perithecial, solitary or scattered, superficial, globose, yellow, membranaceous, surrounded by white, circinately coiled appendages, collapsing when dry, ostiolate with an unconspicuous papilla, periphysate. Peridium 25-65 $\mu \mathrm{m}$ wide, membranaceous, comprising three layers, outer layer composed of hyaline cells of textura globulosa; middle layer composed of yellow cells of textura angularis; inner layer composed of hyaline cells of textura prismatica. Paraphyses absent. Asci (45-)50-60(-65) $\times 7-11 \mu \mathrm{m}(\bar{x}=55 \times 9 \mu \mathrm{m}, \mathrm{n}=20)$, 8-spored, unitunicate, cylindrical, pedicellate, apex rounded, evanescent. Ascospores (10-)12-13(-15) $\times$ (4.5-)5-6(-7) $\mu \mathrm{m}(\bar{x}=12.5 \times 5.5 \mu \mathrm{m}, \mathrm{n}=50)$, bi-seriate, hyaline, ellipsoidal to boat-shaped, straight or slightly curved, 1-septate, striate, with an apical germ pore, guttulate. Asexual morph: Undetermined.

Material examined - Puerto Rico, Caribbean National Forest, Luquillo Mts., El Verde Research Area, alt. 350 m, on Bionectria sp. on decayed wood, 19 February 1996, G.J. Samuels, H.-J. Schroers (BPI-748359, holotype).

Known hosts and distribution - on ascomata of Bionectria or Nectria species on decayed wood in Guyana and Puerto Rico (type locality) (Samuels \& Barr 1997).

Notes - We re-examined the holotype of Circinoniesslia nectriae and found that ascomata of C. nectriae grow on the dried ascomata of Bionectria. Samuels \& Barr (1997) mentioned 'the setose ascomata give the impression of small animals, the mouths of which are fringedd with graceful whiskers'. We observed cross-sections of the appendages of ascomata and found that it is composed of loose and globose cells that swell in water.

Cryptoniesslia Scheuer, Mycol. Res. 97(5): 543 (1993)

Saprobic on leaves. Sexual morph: Ascomata perithecial, solitary, immersed to erumpent, pyriform to subglobose, brown or black, membranaceous, with short setae around the ostioles, periphysate, collapsing when dry. Setae cylindrical, expanded near the apex, aseptate, branched or unbranched, dark brown. Peridium composed of membranaceous, brown to hyaline cells of textura epidermoidea to textura angularis to textura prismatica. Paraphyses cylindrical, unbranched, septate, constricted at the septum. Asci 8-spored, unitunicate, clavate, pedicellate, apex blunt, apical ring indistinct, evanescent. Ascospores bi-seriate or overlapping, hyaline, fusiform, with rounded ends, straight or slightly curved, 1-septate, smooth-walled, guttulate. Asexual morph: Undetermined (adapted from Scheuer 1993).

Notes - The monotypic Cryptoniesslia was established by Scheuer (1993) for C. seutlosa, which has similarly immersed ascomata with special setae to Niesslia and Trichosphaerella. 


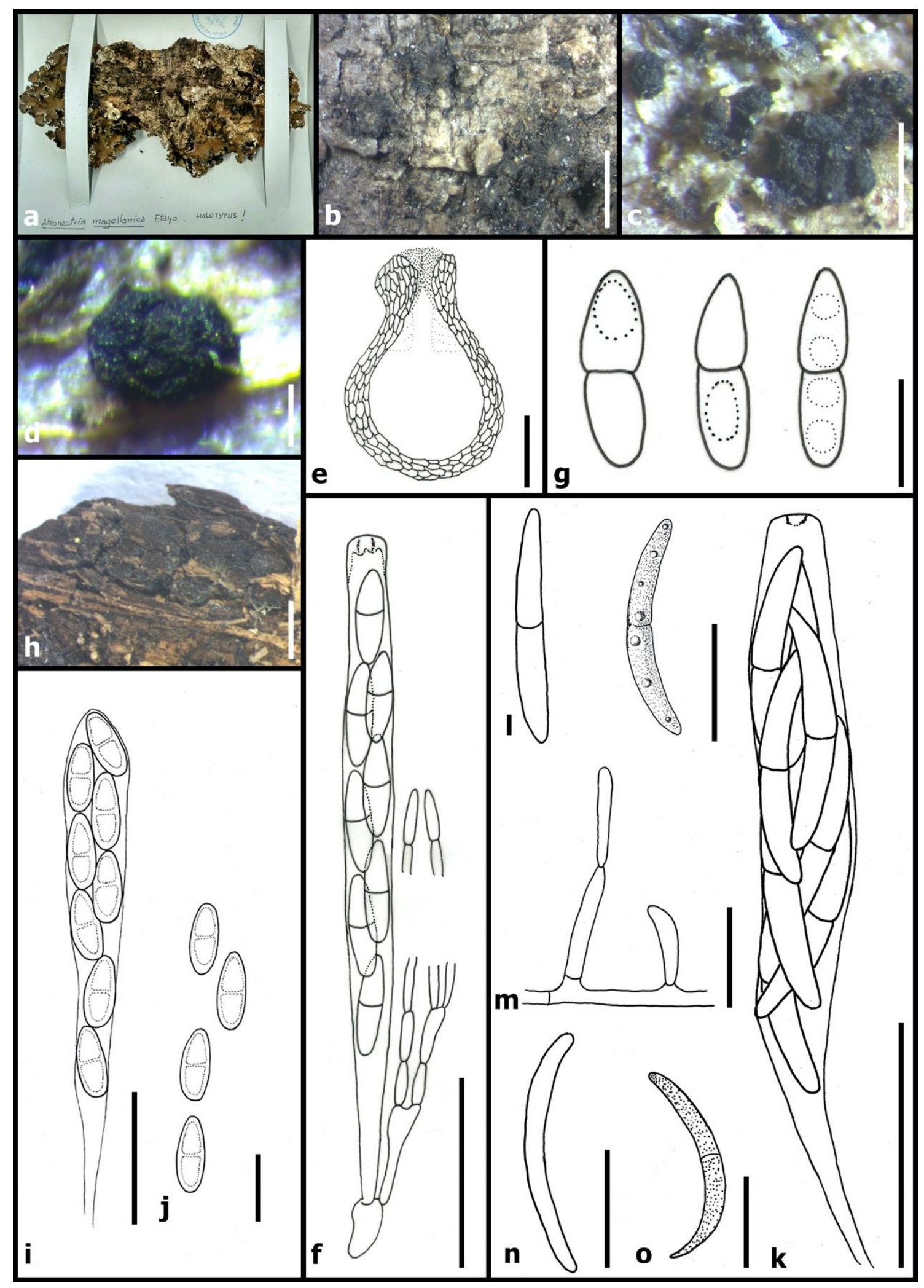

Figure 27 - Atronectria magellanica: a-d (MAF-Etayo 22938, holotype); e-g (redrawn from Etayo \& Sancho 2008). a Material. b-d Ascomata on the host. e Sectional view of ascoma. f Ascus and paraphyses. g Ascospores; Myrmaeciella endoleuca: h (HBG-2347); i-j (redrawn from Jaklitsch \& Voglmayr 2011). h Ascomata on the host. i Ascus. j Ascospores; Eucasphaeria capensis: k-o (redrawn from Crous et al. 2007). k Ascus. 1 Ascospores. m Conidiophores. $\mathrm{n}-\mathrm{o}$ Conidia. Scale bars: $\mathrm{b}=2 \mathrm{~mm}, \mathrm{~h}=1 \mathrm{~mm}, \mathrm{c}=500 \mu \mathrm{m}, \mathrm{d}=200 \mu \mathrm{m}, \mathrm{e}=50 \mu \mathrm{m}, \mathrm{f}, \mathrm{i}, \mathrm{k}, \mathrm{m}=20 \mu \mathrm{m}, \mathrm{j}, \mathrm{l}, \mathrm{n}-\mathrm{o}=10$ $\mu \mathrm{m}, \mathrm{g}=5 \mu \mathrm{m}$. 

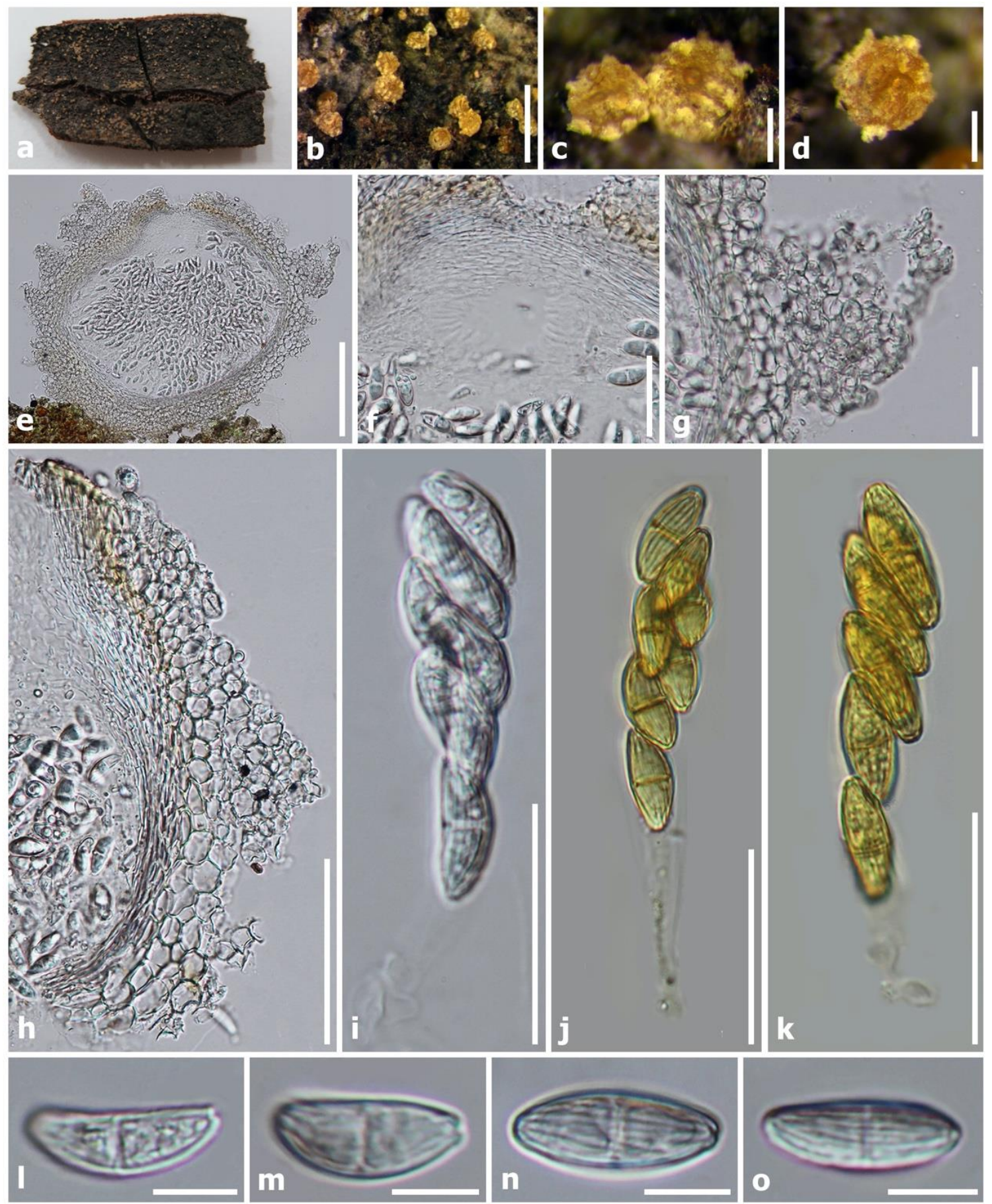

Figure 28 - Circinoniesslia nectriae: (BPI-748359, holotype). a Material. b-d Ascomata on the host. e Ascoma cross section. f Ostiole with periphyses. g Crown appendage cross section. h Peridium. i-k Asci. 1-o Ascospores. Notes: j-k stained in Melzer's reagent. Scale bars: $b=1 \mathrm{~mm}$, $\mathrm{c}-\mathrm{d}=200 \mu \mathrm{m}, \mathrm{e}=100 \mu \mathrm{m}, \mathrm{h}=50 \mu \mathrm{m}, \mathrm{f}-\mathrm{g}, \mathrm{i}-\mathrm{k}=20 \mu \mathrm{m}, \mathrm{l}-\mathrm{o}=5 \mu \mathrm{m}$.

Cryptoniesslia setulosa Scheuer, Mycol. Res. 97(5): 543 (1993)

Fig. 29

Facesoffungi number: FoF 10071

Saprobic on leaves. Sexual morph: Ascomata 100-200 $\mu \mathrm{m}(\bar{x}=155 \mu \mathrm{m}, \mathrm{n}=10)$ diam., perithecial, solitary, immersed to erumpent, pyriform to subglobose, brown or black, membranaceous, with short setae around the ostioles, periphysate, collapsing when dry. Setae cylindrical, expanded near the apex, aseptate, branched or unbranched, dark brown. Peridium 15$40 \mu \mathrm{m}$ wide, membranaceous, comprising three layers, brown cells of textura epidermoidea on surface view; middle layer composed of brown to olivaceous brown cells of textura angularis; 
inner layer composed of hyaline cells of textura prismatica. Paraphyses cylindrical, unbranched, septate, constricted at the septum. Asci (25-)30-35(-40) $\times(8-) 10-13(-15) \mu \mathrm{m}(\bar{x}=32 \times 12 \mu \mathrm{m}, \mathrm{n}$ $=20$ ) at ascospore-bearing part, 8 -spored, unitunicate, clavate, pedicellate, apex blunt, apical ring indistinct, evanescent. Ascospores (15-)20-24 × 2.5-3(-4) $\mu \mathrm{m}(\bar{x}=23 \times 2.8 \mu \mathrm{m}, \mathrm{n}=30)$, bi-seriate or overlapping, hyaline, fusiform, with rounded ends, straight or slightly curved, aseptate when young, becoming 1-septate, smooth-walled, guttulate. Asexual morph: Undetermined (adapted from Scheuer 1993).

Material examined - UK, North Devon, Barnstaple, sand dune system of Braunton Burrows, on decayed leaves of Carex arenariae, 5 August 1988, C. Scheuer (BPI-802277, isotype).

Known hosts and distribution - on decayed leaves of Carex arenariae (Cyperaceae) in the UK (type locality) (Scheuer 1993).

Notes - Cryptoniesslia setulosa was introduced by Scheuer (1993) in having immersed ascomata with special setae surrounded by ostioles, but sequence data are not available.

Eucasphaeria Crous, in Crous, Mohammed, Glen, Verkley \& Groenewald, Fungal Diversity 25: 21 (2007)

Parasitic on leaves and leaf litters. Sexual morph: Ascomata perithecial, solitary or scattered, semi-immersed to superficial, globose to subglobose, black, membranaceous, surrounded by hyaline hyphae, ostiolate, periphysate. Peridium composed of membranaceous, brown cells of textura angularis. Paraphyses absent. Asci 8-spored, unitunicate, cylindrical, pedicellate, apex rounded or blunt, apical ring distinct. Ascospores bi-seriate, hyaline, ellipsoidal to fusiform, straight or curved, 1-septate, verrucose or smooth-walled, sometimes faintly striate, mostly with guttules. Asexual morph: Coelomycetous. Conidiomata semi-immersed, globose to subglobose, acervuloid, dark brown to black. Peridium composed of brown cells of textura angularis, becoming hyaline towards inner conidiogenous region. Conidiophores hyaline, cylindrical to subcylindrical, septate, branched, giving rise to 1-2 conidiogenous cells. Conidiogenous cells fusiform to ellipsoidal, hyaline, phialidic, straight to slightly curved. Conidia in natural environment, cylindrical to oblong, slightly curved, 0-1-septate, hyaline, smooth-walled, guttulate; in culture sporulating, falcate, 0-2septate, hyaline, smooth-walled, guttulate (adapted from Crous et al. 2007, 2016).

Notes - Eucasphaeria was established by Crous et al. (2007), and the type E. capensis was sequenced by Vu et al. (2019). Subsequently, Eucasphaeria rustici and E. proteae were introduced based on morphology and phylogenetic results (Crous et al. 2016, 2020a). In this study, Eucasphaeria is sister to Neocucasphaeria and Rosasphaeria (99\%ML/1.00BY, Fig. 1).

Eucasphaeria capensis Crous, in Crous, Mohammed, Glen, Verkley \& Groenewald, Fungal Diversity 25: 21 (2007)

Fig. $27 \mathrm{k}-\mathrm{O}$

Facesoffungi number: FoF 10174

Parasitic on leaves and leaf litters. Sexual morph: Ascomata perithecial, solitary or scattered, semi-immersed to superficial, globose to subglobose, black, membranaceous, surrounded by hyaline hyphae, ostiolate, periphysate. Peridium composed of membranaceous, brown cells of textura angularis. Paraphyses absent. Asci 8-spored, unitunicate, cylindrical, pedicellate, apex rounded or blunt, apical ring distinct. Ascospores bi-seriate, hyaline, ellipsoidal to fusiform, straight or curved, 1-septate, verrucose or smooth-walled, sometimes faintly striate, mostly with guttules. Asexual morph: Coelomycetous. Conidiomata semi-immersed, globose to subglobose, acervuloid, dark brown to black. Peridium composed of brown cells of textura angularis, becoming hyaline towards the inner conidiogenous region. Conidiophores hyaline, cylindrical to subcylindrical, septate, branched, giving rise to $1-2$ conidiogenous cells. Conidiogenous cells fusiform to ellipsoidal, hyaline, phialidic, straight to slightly curved. Conidia in natural environment, cylindrical to oblong, slightly curved, aseptate, hyaline, smooth-walled, guttulate; in culture sporulating, falcate, 0-2-septate, hyaline, smooth-walled, guttulate (adapted from Crous et al. 2007). 
Known hosts and distribution - on leaves and leaf litters of Eucalyptus in South Africa (type locality) (Crous et al. 2007).

Notes - Eucasphaeria capensis was collected from South Africa and has black ascomata, fuisform ascospores and coelomycetous asexual morph (Crous et al. 2007). Its type strain, $E$. capensis (CBS 120028) was sequenced by $\mathrm{Vu}$ et al. (2019), and it is sister to E. rustici (98\%ML/0.94BY, Fig. 1).
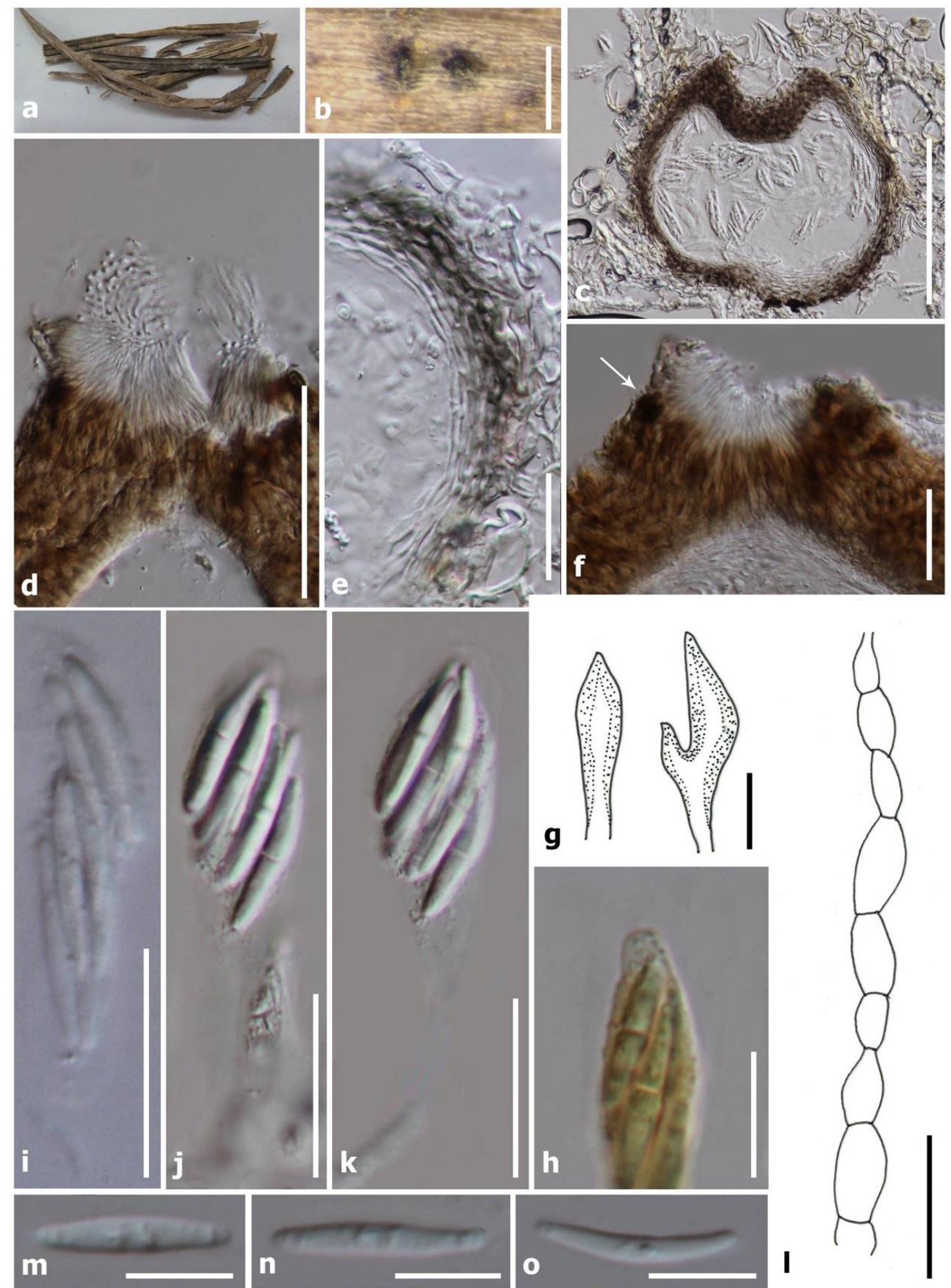

Figure 29 - Cryptoniesslia setulosa: a-f, h-k, m-o (BPI-802277, isotype); g, 1 (redrawn from Scheuer 1993). a Material. b Immersed ascomata. c Ascoma cross section. d, f Ostiole with periphyses (arrow points to setae). e Peridium. g Setae. h Ascus with blunt and thick apex. i-k Asci. 1 Paraphysis. $\mathrm{m}-\mathrm{o}$ Ascospores. Notes: $\mathrm{h}$ stained in Melzer's reagent. Scale bars: $\mathrm{b}=200 \mu \mathrm{m}, \mathrm{c}=$ $100 \mu \mathrm{m}, \mathrm{d}=50 \mu \mathrm{m}, \mathrm{e}-\mathrm{f}, \mathrm{i}-\mathrm{l}=20 \mu \mathrm{m}, \mathrm{g}-\mathrm{h}, \mathrm{m}-\mathrm{o}=10 \mu \mathrm{m}$. 
Malmeomyces Starbäck, Bih. K. svenska VetenskAkad. Handl., Afd. 3 25(no. 1): 32 (1899)

Saprobic on bamboo. Sexual morph: Ascomata perithecial, solitary to scattered, superficial, subglobose, usually collapsing as cupuliform, yellow, membranaceous to coriaceous, surrounded by erect, septate, unbranched, tapering setae with rounded end, ostioles inconspicuous, periphysate. Peridium composed of membranaceous, yellow to hyaline cells of textura angularis to textura prismatica. Paraphyses absent. Asci 8-spored, unitunicate, cylindrical to clavate, pedicellate, apex blunt, apical ring distinct, evanescent. Ascospores bi-seriate or overlapping, hyaline, fusiform, straight or slightly curved, 1-3-septate, smooth-walled, guttulate. Asexual morph: Undetermined (adapted from Starbäck 1899).

Notes - The monotypic Malmeomyces was initially placed in Hypocreaceae (Starbäck 1899), and subsequently accepted at Niessliaceae based on ascomata with erect setae (Lumbsch \& Huhndorf 2010, Maharachchikumbura et al. 2016, Hyde et al. 2020e, Wijayawardene et al. 2020).

Malmeomyces pulchellus Starbäck [as 'pulchella'], Bih. K. svenska VetenskAkad. Handl., Afd. 3 25(no. 1): 32 (1899)

Fig. 30

Facesoffungi number: FoF 10072

Saprobic on bamboo. Sexual morph: Ascomata 130-250 $\mu \mathrm{m}(\bar{x}=180 \mu \mathrm{m}, \mathrm{n}=10)$ diam., perithecial, solitary to scattered, superficial, subglobose, usually collapsing as cupuliform, yellow, membranaceous to coriaceous, surrounded by erect, septate, unbranched, tapering setae, 6-10 $\mu \mathrm{m}$ wide at base, with rounded end, ostioles inconspicuous, periphysate. Peridium 25-60 $\mu \mathrm{m}$ wide, composed of membranaceous, yellow to hyaline cells of textura angularis to textura prismatica. Paraphyses absent. Asci (30-)37-40(-45) $\times(8-) 10-15 \mu \mathrm{m}(\bar{x}=39 \times 12 \mu \mathrm{m}, \mathrm{n}=20)$ at ascosporebearing part, 8-spored, unitunicate, cylindrical to clavate, pedicellate, apex blunt, apical ring distinct, evanescent. Ascospores $(10-) 12-15(-18) \times 2.5-4 \mu \mathrm{m}(\bar{x}=14 \times 3 \mu \mathrm{m}, \mathrm{n}=50)$, bi-seriate or overlapping, hyaline, fusiform, straight or slightly curved, aseptate when young, becoming 1septate, smooth-walled, guttulate. Asexual morph: Undetermined (adapted from Starbäck 1899).

Material examined - Brazil, Rio Grande do Sul, col. Ijuhy, on decayed of Bambusa eujusdam, 1 April 1893, A. Malme (S-F46453, holotype).

Known hosts and distribution - on decayed leaves of Bambusa eujusdam (Bambuseae) in Brazil (type locality) (Starbäck 1899).

Notes - Malmeomyces pulchellus was collected on decayed leaves of bamboo in Brazil and has setose ascomata, clavate asci and 1-3-septate ascospores (Starbäck 1899). In this study, we reexamined the holotype and found that it has 0-1-septate ascospores, but no 2-3-septate ascospores.

Melchioria Penz. \& Sacc., Malpighia 11(9-10): 399 (1897)

Saprobic or parasitic on leaves or stems. Sexual morph: Ascomata perithecial, densely gregarious, superficial, globose to subglobose, black, carbonaceous to coriaceous, glabrous, not collapsing, ostiolate, periphysate. Peridium composed of dark brown to hyaline cells of textura angularis to textura prismatica. Paraphyses absent or filiform. Asci 8-spored, unitunicate, clavate, pedicellate, apical ring indistinct, evanescent. Ascospores bi-seriate or overlapping, hyaline, fusiform, straight or slightly curved, 1-septate, smooth-walled, guttulate. Asexual morph: Undetermined (adapted from Spegazzini 1884, Penzig \& Saccardo 1897).

Notes - Melchioria was initially considered similar to Sphaeria with black ascomata and hyaline, fusiform ascospores (Penzig \& Saccardo 1897). This genus was subsequently listed in Niessliaceae (Lumbsch \& Huhndorf 2007). However, Melchioria does not have setose or hairy ascomata similar to other Niessliaceae members, and there is no molecular data available for this genus. We maintain Melchioria in Niessliaceae pending future work.

Melchioria leucomelaena Penz. \& Sacc., Malpighia 11(9-10): 399 (1897)

Fig. 31

Facesoffungi number: FoF 10073

Saprobic on stems. Sexual morph: Ascomata 290-450 $\mu \mathrm{m}(\bar{x}=380 \mathrm{n}=10)$ diam., perithecial, densely gregarious, superficial, globose to subglobose, tuberculate, black, carbonaceous to 
coriaceous, glabrous, not collapsing, ostiolate, periphysate. Peridium 45-70 $\mu \mathrm{m}$ wide, comprising three layers, outer layer composed of carbonaceous, black tissue; middle layer composed of membranaceous, dark brown cells of textura angularis; inner layer membranaceous, composed of hyaline cells of textura prismatica. Paraphyses absent. Asci $100-120(-140) \times(20-) 24-26(-30) \mu \mathrm{m}$ $(\bar{x}=115 \times 25 \mu \mathrm{m}, \mathrm{n}=20)$ at ascospore-bearing part, 8-spored, unitunicate, clavate, pedicellate, apical ring indistinct, evanescent. Ascospores $(45-) 52-60(-70) \times(6-) 8-10(-14) \mu \mathrm{m}(\bar{x}=57 \times 9.5$ $\mu \mathrm{m}, \mathrm{n}=50$ ), bi-seriate or overlapping, hyaline, fusiform, straight or slightly curved, 1-septate, smooth-walled, guttulate. Asexual morph: Undetermined (adapted from Penzig \& Saccardo 1897).

Material examined - Indonesia, Jawa, Jawa Barat (West), Tjibodas, on decayed stems of Elettaria, N. Nyman (S-F74326); ibid. on stems of Amomum, 1907, v. Höhnel (S-F82127).

Known hosts and distribution - on decayed stems of Elettaria in Indonesia (type locality) (Penzig \& Saccardo 1897).
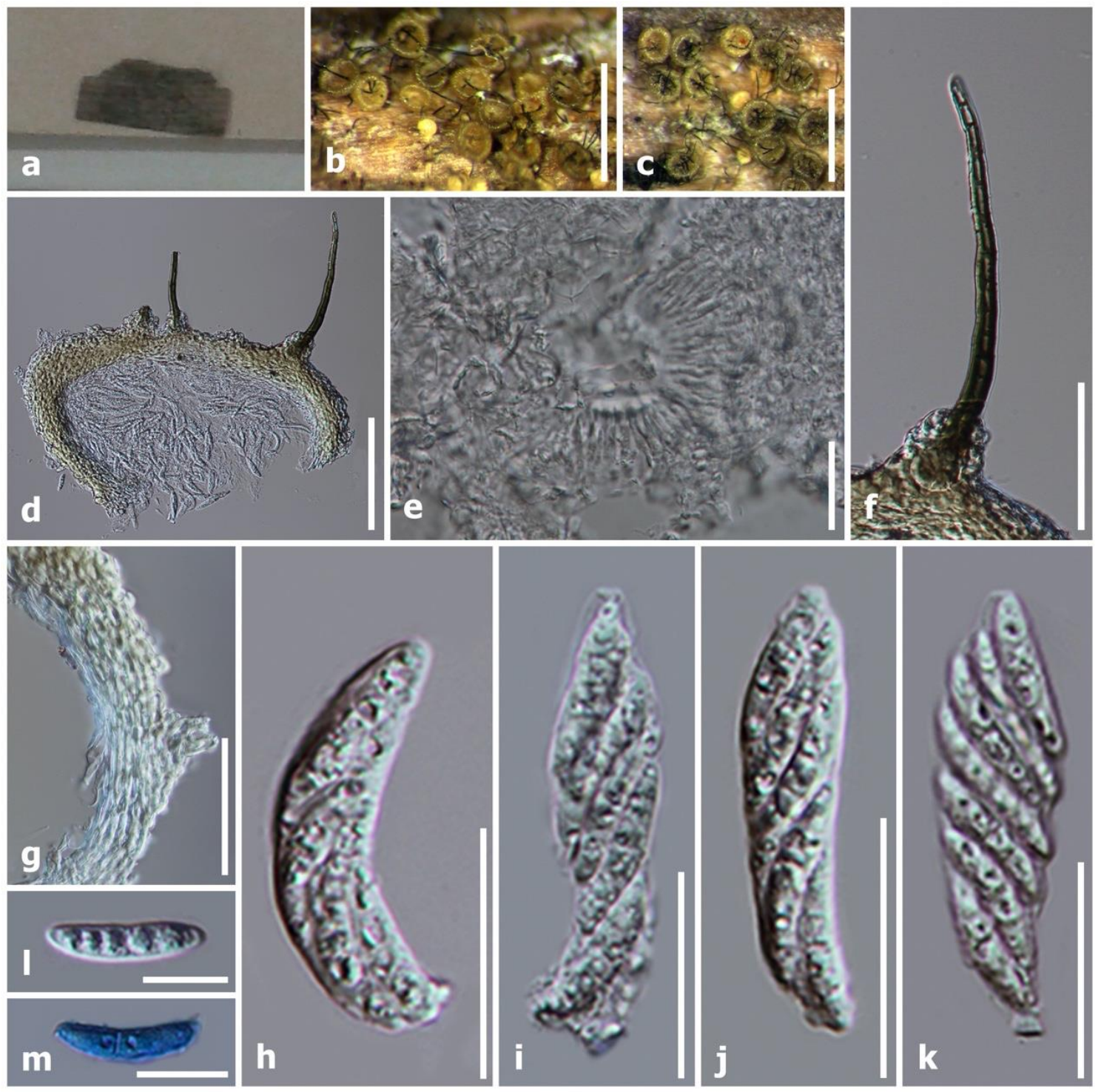

Figure 30 -Malmeomyces pulchellus: (S-F46453, holotype). a Material. b-c Ascomata on the host. $\mathrm{d}$ Ascoma cross section. e Squashed ostiole with periphyses. f Septate setae. g Peridium. h-k Asci. $1-\mathrm{m}$ Ascospores. Notes: $\mathrm{m}$ stained in cotton blue reagent. Scale bars: $\mathrm{b}-\mathrm{c}=500 \mu \mathrm{m}, \mathrm{d}=100 \mu \mathrm{m}, \mathrm{f}-$ $\mathrm{g}=50 \mu \mathrm{m}, \mathrm{e}, \mathrm{h}-\mathrm{k}=20 \mu \mathrm{m}, \mathrm{l}-\mathrm{m}=10 \mu \mathrm{m}$.

Notes - Melchioria leucomelaena was found on the rotten stems of Elettaria in Indonesia and is characterized by black ascomata with fusiform ascospores (Penzig \& Saccardo 1897) but no 
molecular data is available for this species. In this study, the type material is unable to obtain. Therefore, we re-examined two authentic materials collected from Indonesia by Nyman and Höhnel respectively.

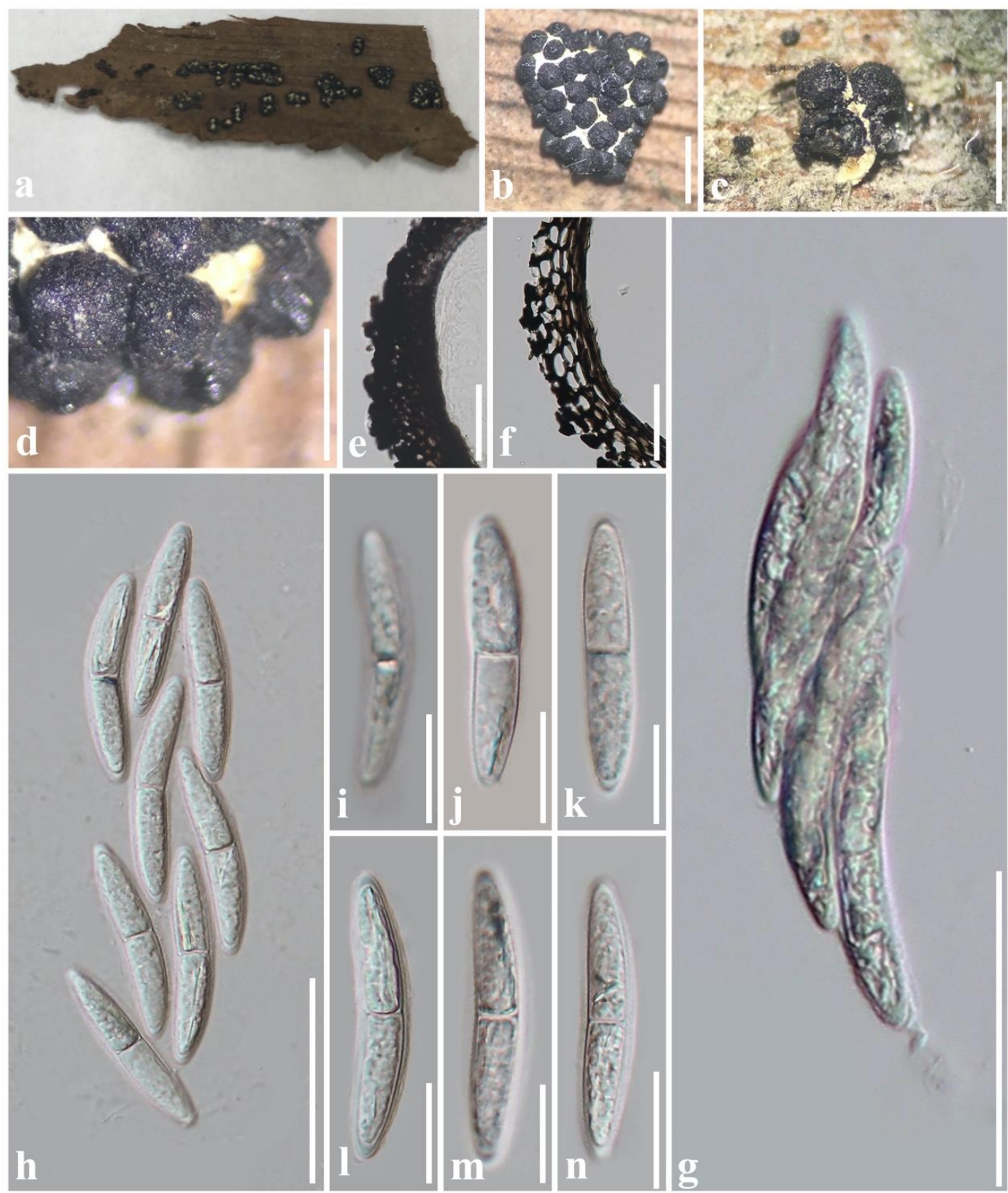

Figure 31 - Melchioria leucomelaena: a-b, d, f-n (S-F74326); c, e (S-F82127). a Material. b-c Ascomata on the host. d Ascomata. e-f Peridium. g-h Evanescent asci. i-n Ascospores. Scale bars: $\mathrm{b}-\mathrm{c}=1 \mathrm{~mm}, \mathrm{~d}=500 \mu \mathrm{m}, \mathrm{e}-\mathrm{h}=50 \mu \mathrm{m}, \mathrm{i}-\mathrm{n}=20 \mu \mathrm{m}$.

Miyakeomyces Hara, Bot. Mag., Tokyo 27(no. 317): (248) (1913)

Parasitic on leaves. Sexual morph: Ascomata perithecial, densely gregarious, penetrated, globose to subglobose, black, coriaceous to membranaceous, glabrous, collapsing when dry, ostiolate, periphysate. Peridium composed of membranaceous, olivaceous brown to hyaline cells of textura intricata to textura angularis to textura prismatica. Paraphyses absent. Asci 8-spored, unitunicate, cylindrical to clavate, pedicellate, apex rounded, apical ring indistinct, evanescent. Ascospores bi-seriate, hyaline, ellipsoidal to fusiform, straight or slightly curved, 2-4-septate, smooth-walled, guttulate. Asexual morph: Undetermined (adapted from von Höhnel 1918). 
Notes - The monotypic Miyakeomyces was found to be parasitic on leaves of Phyllostachys (Hara 1913). von Höhnel (1918) observed that M. bambusae makes the leaf yellow and thick, and its fruiting bodies appear on both sides of the leaf.

Miyakeomyces bambusae Hara [as 'Miyakeamyces'], Bot. Mag., Tokyo 27(no. 317): (248) (1913)

Fig. 32

Facesoffungi number: FoF 10074

Parasitic on leaves. Sexual morph: Ascomata densely aggregate into an ellipsoid, gradually thinning towards the edge, $450-520 \times 500-650 \mu \mathrm{m}(\bar{x}=480 \times 570 \mu \mathrm{m}, \mathrm{n}=5)$ diam., perithecial, penetrated, globose to subglobose, $100-150 \mu \mathrm{m}(\bar{x}=120 \mu \mathrm{m}, \mathrm{n}=10)$ diam., black, coriaceous to membranaceous, glabrous, collapsing when dry, ostiolate, periphysate. Peridium 16-40 $\mu \mathrm{m}$ wide, membranaceous, comprising three layers, outer layer composed of olivaceous brown cells of textura intricata; middle layer composed of olivaceous brown cells of textura angularis; inner layer composed of hyaline cells of textura prismatica. Paraphyses absent. Asci (50-)60-70 × 11-13 $\mu \mathrm{m}$ $(\bar{x}=65 \times 12 \mu \mathrm{m}, \mathrm{n}=10), 8$-spored, unitunicate, cylindrical to clavate, pedicellate, apex rounded, apical ring indistinct, evanescent. Ascospores $(20-) 23-26(-30) \times(4-) 5-6(-7) \mu \mathrm{m}(\bar{x}=25 \times 5 \mu \mathrm{m}, \mathrm{n}$ $=20$ ), bi-seriate, hyaline, ellipsoidal to fusiform, straight or slightly curved, aseptate, smoothwalled, guttulate. Asexual morph: Undetermined.

Material examined - Japan, Gifu, prov. Mino, Kawauye-mura, on leaves of Phyllostachys bambusoides, 11 November 1911, K. Hara (S-F10914, Isolectotype).

Known hosts and distribution - on leaves of Phyllostachys bambusoides (Poaceae) in Japan (type locality) (Hara 1913).

Notes - Miyakeomyces bambusae was introduced as a parasitic species on bamboo leaves and in having 2-4-septate, fusiform ascospores (von Höhnel 1918). In this study, we only found aseptate ascospores in the isolectotype material.

Myrmaeciella Lindau, in Engler \& Prantl, Nat. Pflanzenfam., Teil. I (Leipzig) 1(1): 478 (1897)

Saprobic on wood. Sexual morph: Ascomata perithecial, densely gregarious, superficial, globose to subglobose, black, membranaceous, glabrous, ostioles inconspicuous. Peridium composed of dark brown cells of textura angularis. Paraphyses absent. Asci 8-spored, unitunicate, clavate, pedicellate or sessile, evanescent. Ascospores uni- to bi-seriate, hyaline, ellipsoidal to oblong, straight or slightly curved, 1-septate, guttulate. Asexual morph: Undetermined (adapted from Saccardo 1880, Theissen 1910, Jaklitsch \& Voglmayr 2011).

Notes - Myrmaeciella was treated as a synonym of Hypocreopsis (Müller \& von Arx 1962, Rogerson 1970). Rossman et al. (1999) subsequently transferred Myrmaeciella to Niessliaceae based on their similar membranaceous ascomata, inamyloid asci and ellipsoidal ascospores.

Myrmaeciella endoleuca (Sacc.) Lindau, in Engler \& Prantl, Nat. Pflanzenfam., Teil. I (Leipzig) 1(1): 478 (1897)

Fig. $27 \mathrm{~h}-\mathrm{j}$

Basionym - Myrmaecium endoleucum Sacc., Michelia 2(no. 6): 138 (1880)

Facesoffungi number: FoF 10175

Saprobic on wood. Sexual morph: Ascomata perithecial, densely gregarious, superficial, globose to subglobose, black, membranaceous, glabrous, ostioles inconspicuous. Peridium composed of dark brown cells of textura angularis. Paraphyses absent. Asci 8-spored, unitunicate, clavate, pedicellate, evanescent. Ascospores uni- to bi-seriate, hyaline, ellipsoidal, 1-septate, guttulate. Asexual morph: Undetermined (adapted from Saccardo 1880, Jaklitsch \& Voglmayr 2011).

Material examined - Switzerland, on decayed wood, 11 February 1962, E. Müller and J.A. von Arx (HBG-2347).

Known hosts and distribution - on decayed wood in Switzerland and the USA (type locality) (Saccardo 1880). 
Notes - The type material of Myrmaeciella endoleuca could not be obtained. Therefore, we re-examined the authentic materials collected by Müller and Arx. A kind of hyphomycetes with globose conidia contaminated this specimen, and except for the shriveled ascomata, no other features were observed in this study.
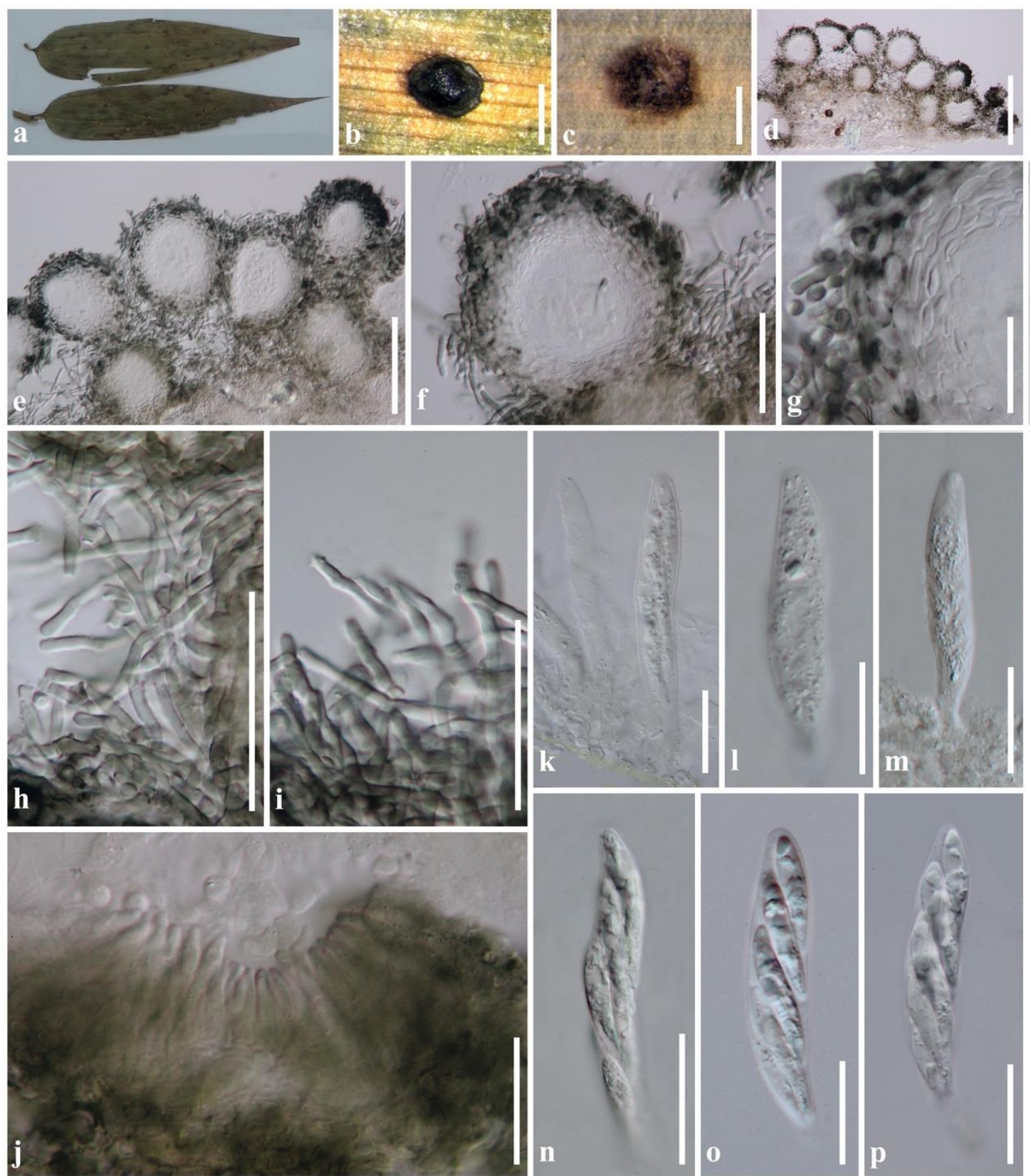

Figure 32 - Miyakeomyces bambusae: (S-F10914, Isolectotype). a Material. b-c Ascomata on the host ( $b$ on front of the leaf, $c$ on back of the leaf). d-e Ascomata cross section. $f$ Ascoma. $\mathrm{g}$ Peridium. $\mathrm{h}-\mathrm{i}$ Olivaceous brown cells of textura intricata. $\mathrm{j}$ Squashed ostiole. $\mathrm{k}-\mathrm{p}$ Asci. Scale bars: $\mathrm{b}-\mathrm{c}=500 \mu \mathrm{m}, \mathrm{d}=200 \mu \mathrm{m}, \mathrm{e}=100 \mu \mathrm{m}, \mathrm{f}, \mathrm{h}-\mathrm{i}=50 \mu \mathrm{m}, \mathrm{g}, \mathrm{j}-\mathrm{p}=20 \mu \mathrm{m}$.

Myrtacremonium Crous, in Crous et al., Persoonia 38: 259 (2017)

Parasitic on leaves. Sexual morph: Undetermined. Asexual morph: Hyphomycetous. Mycelium hyaline, septate, branched hyphae. Conidiophores mononematous, macronematous, hyaline, straight to flexuous. Conidiogenous cells terminal, hyaline, subcylindrical, with minute flared collarette at apex. Conidia solitary, oblong, aseptate, hyaline, smooth-walled, guttulate (adapted from Crous et al. 2017). 
Notes - The hyphomycetous genus Myrtacremonium was accepted in Niessliaceae based on phylogenetic result (Crous et al. 2017). In this study, Myrtacremonium nests in Niessliaceae (70\%ML/0.99BY, Fig. 1).

Myrtacremonium eucalypti Crous, in Crous et al., Persoonia 38: 259 (2017)

Fig. $33 \mathrm{~m}$

Facesoffungi number: FoF 10176

Parasitic on leaves. Sexual morph: Undetermined. Asexual morph: Hyphomycetous. Mycelium hyaline, septate, branched hyphae. Conidiophores mononematous, macronematous, hyaline, straight to flexuous. Conidiogenous cells terminal, hyaline, subcylindrical, with minute flared collarette at apex. Conidia solitary, oblong, aseptate, hyaline, smooth-walled, guttulate (adapted from Crous et al. 2017).

Known hosts and distribution - on leaves of Eucalyptus globulus (Myrtaceae) in Australia (type locality) (Crous et al. 2017).

Notes - The monotypic Myrtacremonium was introduced by Crous et al. (2017) for $M$. eucalypti.

Neoeucasphaeria Crous, in Crous et al., Persoonia 41: 293 (2018)

Parasitic on Eucalyptus. Sexual morph: Undetermined. Asexual morph: Hyphomycetous. Mycelium hyaline, septate, branched hyphae. Conidiophores mononematous, macronematous, densely gregarious, hyaline, straight to flexuous, branched. Conidiogenous cells terminal, hyaline, subcylindrical, phialidic, flexuous. Conidia solitary, ellipsoidal, aseptate, hyaline, smooth-walled, guttulate (adapted from Crous et al. 2018).

Notes - The monotypic Neoeucasphaeria was collected from Eucalyptus in Australia (Crous et al. 2018). In this study, Neoeucasphaeria is sister to Rosasphaeria in Niessliaceae (Fig. 1). Rosasphaeria has cylindrical, curved, 1-septate conidia different from Neoeucasphaeria (Jaklitsch \& Voglmayr 2012).

Neoeucasphaeria eucalypti Crous, in Crous et al., Persoonia 41: 293 (2018)

Facesoffungi number: FoF 10177

Parasitic on Eucalyptus. Sexual morph: Undetermined. Asexual morph: Hyphomycetous. Mycelium hyaline, septate, branched hyphae. Conidiophores mononematous, macronematous, densely gregarious, hyaline, straight to flexuous, branched. Conidiogenous cells terminal, hyaline, subcylindrical, phialidic, flexuous. Conidia solitary, ellipsoidal, aseptate, hyaline, smooth-walled, guttulate (adapted from Crous et al. 2018).

Known hosts and distribution - on Eucalyptus in Australia (type locality) (Crous et al. 2018).

Notes - The hyphomycetous Neoeucasphaeria eucalypti was introduced by Crous et al. (2018) from Australia. It is sister to Rosasphaeria moravica (Fig. 1), differing from it in the possessing of ellipsoidal conidia (Jaklitsch \& Voglmayr 2012).

Niesslia Auersw., in Gonnermann \& Rabenhorst, Myc. Europ. Pyren. 5-6: 30 (1869)

Saprobic on wood, leaves or stems. Sexual morph: Ascomata perithecial, solitary or gregarious, superficial, sometimes sitting on a subiculum, globose to subglobose, or collapsing as cupuliform, brown or black, membranaceous, surrounded by brown to black setae, ostioles inconspicuous, periphysate. Peridium composed of membranaceous, yellow or brown to hyaline cells of textura angularis to textura prismatica. Paraphyses absent. Asci 8-spored, unitunicate, cylindrical to clavate, pedicellate, apex rounded or blunt, apical ring indistinct or absent, evanescent. Ascospores uni- or bi-seriate or overlapping, hyaline, ellipsoidal, cylindrical to fusiform, straight or curved, usually 1-septate, smooth-walled, guttulate. Asexual morph: Hyphomycetous. Conidiophores mononematous, macronematous, hyaline, unbranched. Conidia formed in chains or oval to ellipsoidal, 0-1-septate, hyaline, smooth-walled, guttulate (adapted from Gams et al. 2019). 
Notes - Niesslia was introduced by Auerswald (1869) for $N$. chaetomium and it is characterized by spiny ascomata, ellipsoidal ascospores and acremonium-like asexual morph (Gams et al. 2019). Gams et al. (2019) clarified the affinities of Niesslia species by reviewing the authentic specimens. Several Niesslia species were sequenced (Crous et al. 2019a, Gams et al. 2019, Vu et al. 2019), but there is no molecular data available about the type N. chaetomium. In this study, species of Niesslia are scattered in Niessliaceae (Fig. 1).

Niesslia chaetomium (Ces. \& De Not.) Auersw., in Gonnermann \& Rabenhorst, Myc. Europ. Pyren. 5-6: 30 (1869)

Fig. $33 j-1$

Basionym - Venturia chaetomium Ces. \& De Not., Comm. Soc. crittog. Ital. 1(fasc. 4): 225 (1863)

Facesoffungi number: FoF 01128

Saprobic on coniferous substrates. Sexual morph: Ascomata perithecial, solitary or scattered, superficial, globose to subglobose, or collapsing as cupuliform, black, membranaceous, ostiolate, surrounded by long, brown to black, conical, aseptate, tapering setae. Peridium composed of membranaceous, brown cells of textura angularis. Paraphyses absent. Asci 8-spored, unitunicate, cylindrical, pedicellate, apex blunt, evanescent. Ascospores uni- or bi-seriate, hyaline, ellipsoidal to fusiform, straight or slightly curved, usually 1-septate, smooth-walled, guttulate. Asexual morph: Undetermined (adapted from Gams et al. 2019).

Known hosts and distribution - on decayed wood of Pinus and Juniperus in Czech Republic (type locality), France, Germany, the UK and Venezuela (Corda 1838, Gams et al. 2019).

Notes - Niesslia was established based on N. chaetomium (Auerswald 1869), and afterwards, this species was treated as a synonym of $N$. exosporioides (Index Fungorum 2021). Gams et al. (2019) examined specimens related to Niesslia, and proposed that the substrates of N. chaetomium and $N$. exosporioides are different. Niesslia chaetomium was considered a synonym of $N$. pusilla (Gams et al. 2019), but no molecular data available for these two species.

Niesslia exosporioides (Desm.) G. Winter, Rabenh. Krypt.-Fl., Edn 2 (Leipzig) 1.2: 197 (1885)

Basionym - Sphaeria exosporioides Desm., Nouv. Not.: 39 (1843)

Fig. 33a-i

Facesoffungi number: FoF 10178

Saprobic on grasses and similar substrates. Sexual morph: Ascomata 120-210 $\mu \mathrm{m}(\bar{x}=170$ $\mu \mathrm{m}, \mathrm{n}=5$ ), perithecial, solitary or scattered, superficial, globose to subglobose, or collapsing as cupuliform, black, membranaceous, surrounded by long, brown to black, filiform, septate, tapering setae, 4-9 $\mu \mathrm{m}$ wide at the base, ostioles inconspicuous, periphysate. Peridium 15-30 $\mu \mathrm{m}$ wide, composed of membranaceous, brown cells of textura angularis. Paraphyses absent. Asci 8-spored, unitunicate, cylindrical, pedicellate, apex blunt, evanescent. Ascospores $9-12 \times 1-1.6 \mu \mathrm{m}(\bar{x}=10 \times$ $1.2 \mu \mathrm{m}, \mathrm{n}=20$ ), uni- or bi-seriate, hyaline, ellipsoidal to fusiform, straight or slightly curved, usually 1-septate, smooth-walled, guttulate. Asexual morph: Hyphomycetous. Conidiophores mononematous, macronematous, hyaline, unbranched. Conidia cylindrical, hyaline, smooth-walled, guttulate (adapted from Gams et al. 2019).

Material examined - Austria, Niederdonau, Hainburg, Hundsheimer Kogel, on dead stems of Carex pilosa, May 1940, F. Petrak (PRM-717659).

Known hosts and distribution - on decayed leaves or stems of Carex, Luzula and Festuca in Argentina, Austria, Belgium and France (type locality) (Gams et al. 2019).

Notes - Niesslia exosporioides was introduced by Winter (1885) based on Sphaeria exosporioides. It was considered as a synonym of $N$. chaetomium (Index Fungorum 2021). However, Gams et al. (2019) disagreed with this statement. In this study, we re-examined authentic material of $N$. exosporioides collected by Petrak and found that it has ascomata with filiform, septate setae, differing from $N$. chaetomium that has ascomata with erect, spinous, aseptate setae (Corda 1838, Gams et al. 2019). 


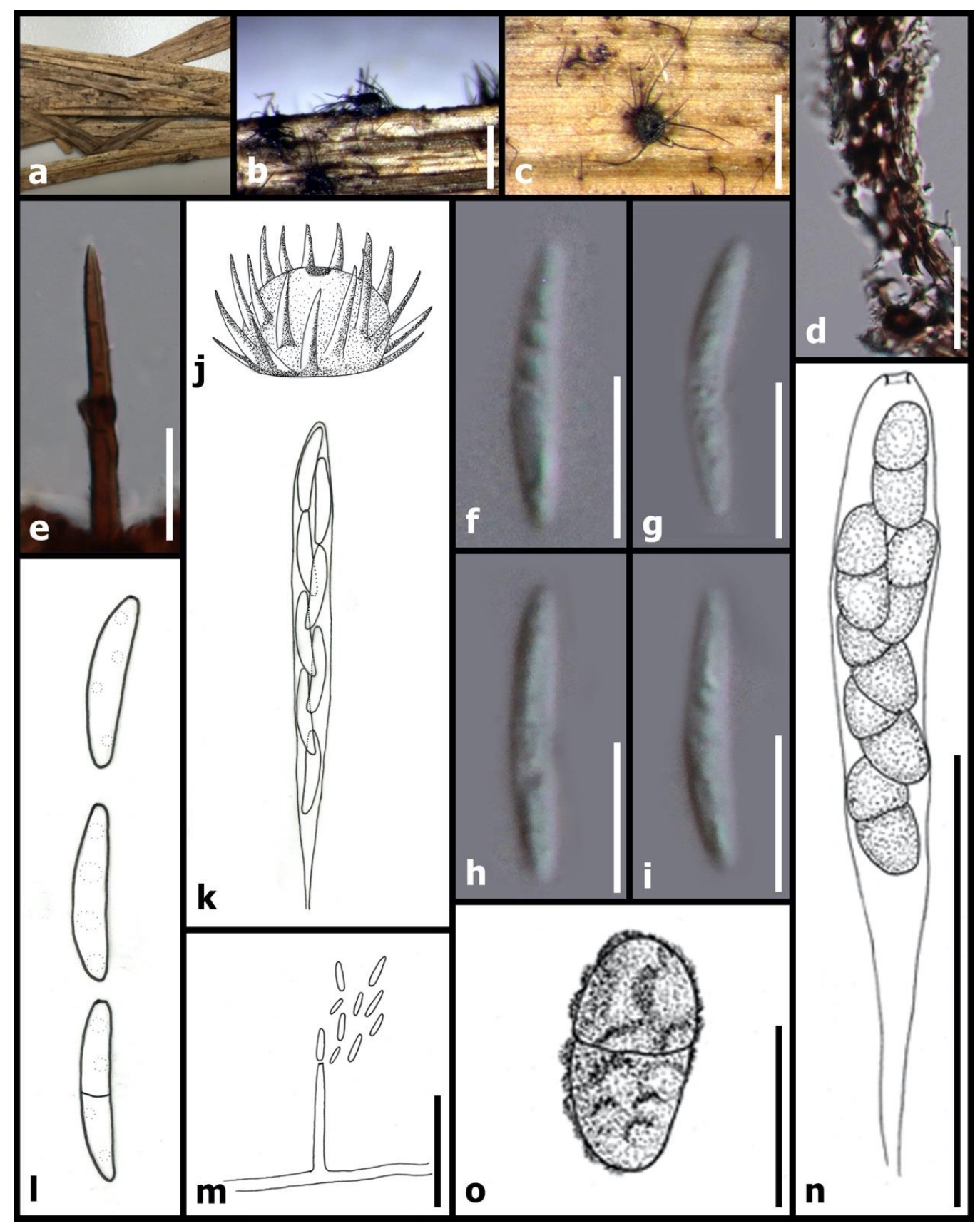

Figure 33 - Niesslia exosporioides: a-i (PRM-717659). a Material. b-c Ascomata on the host. d Peridium. e Septate seta. f-i Ascospores; Niesslia chaetomium: j-1 (redrawn from Corda 1838). j Ascoma. k ascus. 1 Ascospores; Myrtacremonium eucalypti: m (redrawn from Crous et al. 2017). $\mathrm{m}$ Conidiophores and conidia; Paraniesslia tuberculata: $\mathrm{n}-\mathrm{o}$ (redrawn from Tsui et al. 2001). n Ascus. o Ascospores. Scale bars: $\mathrm{b}-\mathrm{c}=500 \mu \mathrm{m}, \mathrm{n}=50 \mu \mathrm{m}, \mathrm{d}, \mathrm{m}=20 \mu \mathrm{m}, \mathrm{e}, \mathrm{o}=10 \mu \mathrm{m}, \mathrm{f}-\mathrm{i}=5$ $\mu \mathrm{m}$.

Niesslia nolinae (A.W. Ramaley) W. Gams, in Gams, Stielow, Gräfenhan \& Schroers, Mycol. Progr. 18(1-2): 34 (2019)

Fig. 34

Basionym - Hyaloseta nolinae A.W. Ramaley, Mycotaxon 79: 269 (2001)

Facesoffungi number: FoF 10179

Saprobic on leaves or leaf litter. Sexual morph: Ascomata perithecial, solitary or gregarious, superficial, sitting on a subiculum with hyaline hyphae, globose to subglobose, collapsing when dry, brown, membranaceous, surrounded by setae, ostioles inconspicuous, periphysate. Setae cylindrical, aseptate, hyaline, tapering, with swollen apex. Peridium composed of membranaceous, brown cells of textura epidermoidea. Paraphyses absent. Asci 8-spored, unitunicate, cylindrical, 
pedicellate, apex rounded, evanescent. Ascospores bi-seriate, hyaline, ellipsoidal to oblong, 1septate, smooth-walled, guttulate. Asexual morph: Hyphomycetous. Mycelium white to orange, superficial, effuse. Conidiophores mononematous, macronematous, hyaline, unbranched, aseptate. Conidia (2-)3.5-4(-4.5) $\times 1-2 \mu \mathrm{m}(\bar{x}=3.8 \times 1.5 \mu \mathrm{m}, \mathrm{n}=50)$, terminal, oval to ellipsoidal, aseptate, hyaline, smooth-walled, guttulate (adapted from Ramaley 2001).

Material examined - USA, New Mexico, Lincoln Co., Valley of Fires, on leaf litter of Nolina micrantha, 22 October 1997, A.W. Ramaley (BPI-871322, holotype).

Known hosts and distribution - on leaves of Nolina micrantha (Asparagaceae) in the USA (type locality) (Ramaley 2001).

Notes - Niesslia nolinae initially introduced as Hyaloseta nolinae from the USA (Ramaley 2001). Gams et al. (2019) subsequently accepted this species in Niesslia based on its ascomata with hyaline setae similar to $N$. pandani. Niesslia nolinae was sequenced by Lombard et al. (2015) and Vu et al. (2019). In this study, N. nolinae is sister to N. gamsii (97\%ML/1.00BY, Fig. 1), differing from the latter that has oblong, clavate or ampulliform conidia (Ashrafi et al. 2017).

Nitschkiopsis Nannf. \& R. Sant., in Nannfeldt, Svensk bot. Tidskr. 69: 322 (1975)

Lichenicolous. Sexual morph: Ascomata perithecial, solitary or scattered, semi-immersed to superficial, globose to subglobose, or collapsing as cupuliform, brown to black, with metallic iridescence, membranaceous, surrounded by two types of setae, ostiolate, periphysate. Setae oblong to cylindrical, hyaline, with swollen apex; conical, spinous, brown to dark brown. Peridium composed of membranaceous, pale brown to reddish brown to hyaline cells of textura angularis to textura prismatica. Paraphyses absent. Asci 8-spored, unitunicate, cylindrical, pedicellate, apex blunt, apical ring indistinct, evanescent. Ascospores uni- or bi-seriate, hyaline, ellipsoidal to oval, 0-1-septate, smooth-walled, guttulate. Asexual morph: Undetermined (adapted from Nannfeldt \& Santesson 1975).

Notes - The monotypic Nitschkiopsis was introduced by Nannfeldt \& Santesson (1975) for N. stictarum. This lichenicolous genus was initially related to Lasiosphaeriaceae and Nitschkiaceae (Nannfeldt \& Santesson 1975). However, Tretiach (2002) transferred it as Niesslia stictarum and introduced another similar lichenicolous species, Nie. robusta. In this study, we found that Nitschkiopsis has perithecial ascomata with hyaline setae similar to Nie. nolinae; and spinous setae similar to Nie. chaetomium, differing from it in the possessing of ellipsoidal ascospores. Since Niesslia is polyphyletic (Fig. 1), we accept the Nitschkiopsis with two kinds of setae as an independent genus in Niessliaceae pending molecular data.

Nitschkiopsis stictarum Nannf. \& R. Sant., Svensk bot. Tidskr. 69(3): 322 (1975)

Fig. 35

Facesoffungi number: FoF 10075

Lichenicolous. Sexual morph: Ascomata $70-130 \mu \mathrm{m}(\bar{x}=105 \mu \mathrm{m}, \mathrm{n}=10)$ diam., perithecial, solitary or scattered, semi-immersed to superficial, globose to subglobose, or collapsing as cupuliform, brown to black, with metallic iridescence, membranaceous, surrounded by two types of setae, ostiolate, periphysate. Setae oblong to cylindrical, hyaline, with swollen apex, $45-85 \times 3.5-5$ $\mu \mathrm{m}$; conical, spinous, brown to dark brown, 9-25 $\times 3-12 \mu \mathrm{m}$. Peridium 10-20 $\mu \mathrm{m}$ wide, membranaceous, comprising three layers, outer layer composed of pale brown cells of textura angularis; middle layer composed of reddish brown to brown cells of textura angularis; inner layer composed of hyaline cells of textura prismatica. Paraphyses absent. Asci $(20-) 25-30(-40) \times(4-$ )5-6.5 $\mu \mathrm{m}(\bar{x}=28 \times 5.4 \mu \mathrm{m}, \mathrm{n}=20)$ at ascospore-bearing part, 8-spored, unitunicate, cylindrical, pedicellate, apex blunt, apical ring indistinct, evanescent. Ascospores (5-)6-8(-8.5) $\times(1.5-) 2-$ $2.5(-3) \mu \mathrm{m}(\bar{x}=7.2 \times 2.3 \mu \mathrm{m}, \mathrm{n}=50)$, uni- or bi-seriate, hyaline, ellipsoidal to oval, 0-1-septate, smooth-walled, guttulate. Asexual morph: Undetermined (adapted from Nannfeldt \& Santesson 1975).

Material examined - Kenya, Central, Nanyku. Mt. Kenys, W slope, National Park Road (Naro Moru Track), in the bamboo zone, Alt. 2700-3100 m, on Sticta ambavillaria on bamboo (Arundinaria alpina), 23 January 1970, R. Santesson (UPS-UPS:BOT:L-112114, holotype); ibid. 
(S-F10356, Isotype); ibid. (UPS-UPS:BOT:F-521855); Tanzania, Arusha, Mt. Meru, E slope, c. 2 $\mathrm{km} \mathrm{N}$ of Kitoto Camp, on Hypericum lanceolatum in a high and relatively dense ericaceous bushland (in the montane forest belt), on Sticta ambavillaria, 7 January 1971, R. Santesson (UPSUPS:BOT:F-521848).
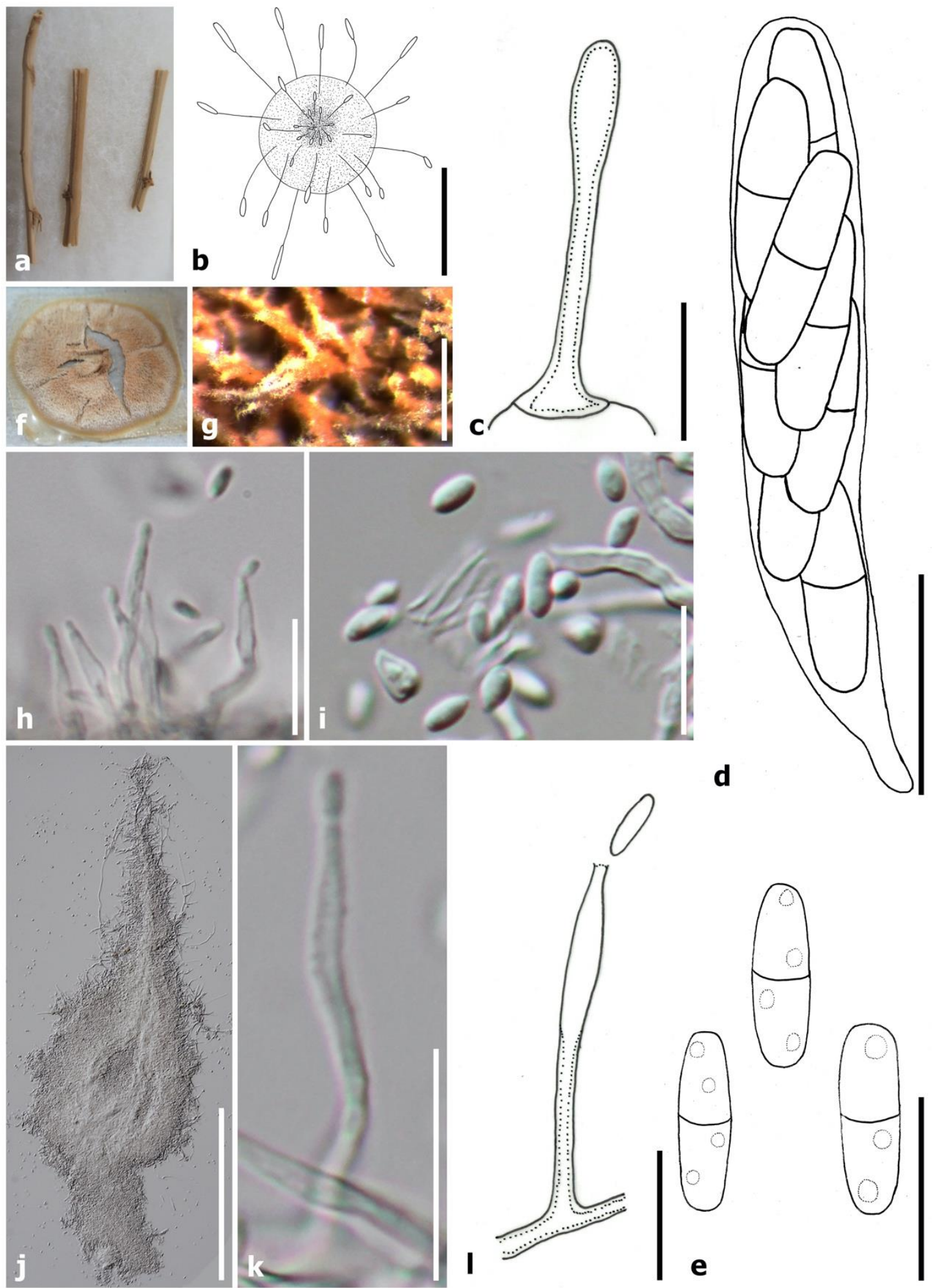

Figure 34 - Niesslia nolinae: a, f-k (BPI-871322, holotype); b-e, 1 (redrawn from Ramaley 2001). a Material. b Ascoma. c Seta with swollen apex. d Ascus. e Ascospores. f Dry culture. g Mycelium. $\mathrm{h}, \mathrm{k}-\mathrm{l}$ Conidiophores and conidia. i Conidia. j Sporodochium. Scale bars: $\mathrm{g}=500 \mu \mathrm{m}, \mathrm{j}=200 \mu \mathrm{m}$, $\mathrm{b}=100 \mu \mathrm{m}, \mathrm{c}-\mathrm{e}, \mathrm{h}-\mathrm{i}, \mathrm{k}-\mathrm{l}=10 \mu \mathrm{m}$. 

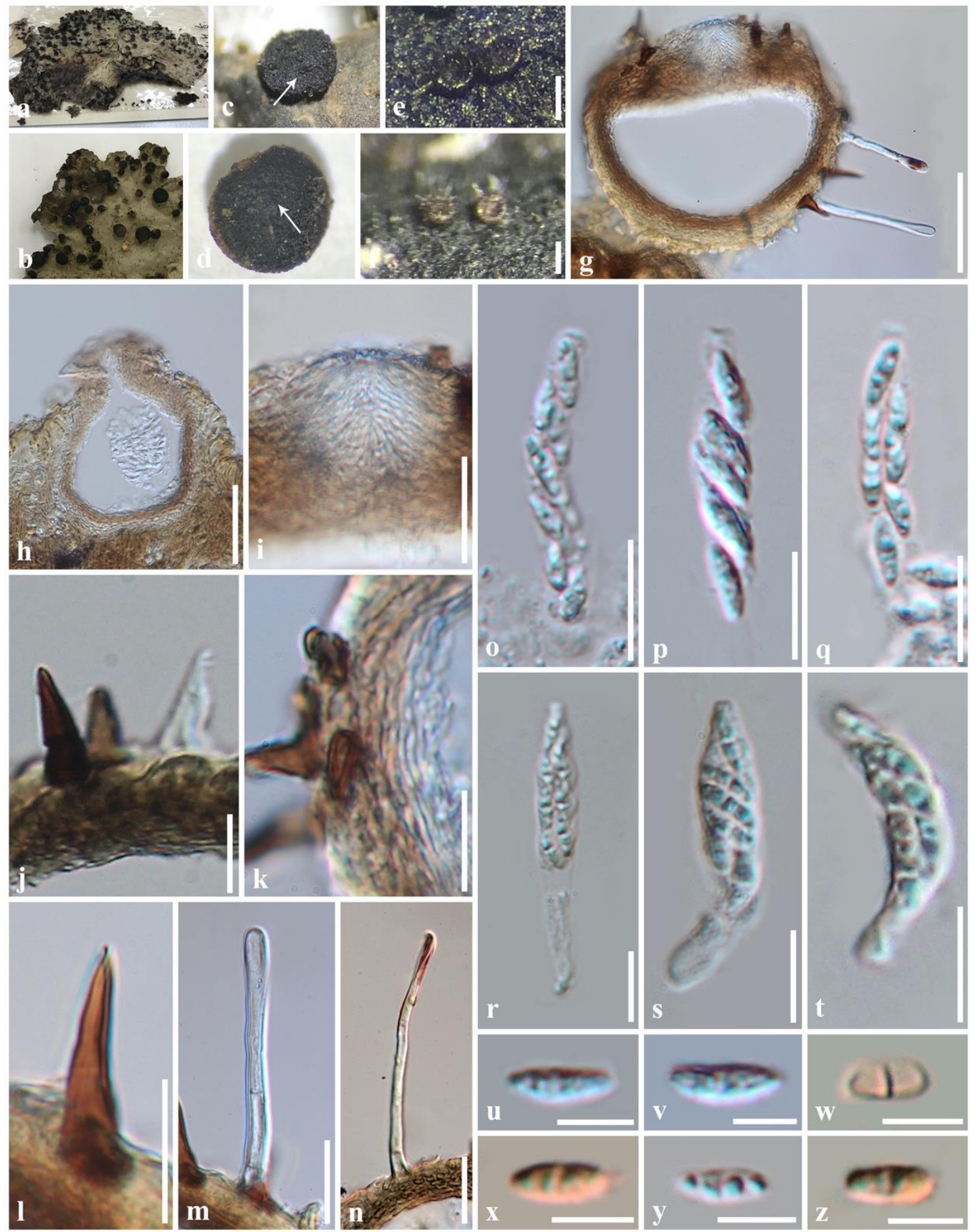

Figure 35 - Nitschkiopsis stictarum: a, c, e, g-i, k-m, o-p, u (UPS-UPS:BOT:L-112114, holotype); b, d, f, j, n, r-t, w-z (S-F10356, Isotype); v (UPS-UPS:BOT:F-521855); q (UPSUPS:BOT:F-521848), a-b Material. c-d Ascomata on Sticta ambavillaria. e-f Ascomata. $\mathrm{g}-\mathrm{h}$ Ascoma cross section. i Ostiole with periphyses. $\mathrm{j}-\mathrm{k}$ Peridium. 1 Conical seta. $\mathrm{m}-\mathrm{n}$ Cylindrical setae. $\mathrm{o}-\mathrm{t}$ Asci. $\mathrm{u}-\mathrm{z}$ Ascospores. Notes: $\mathrm{n}, \mathrm{w}-\mathrm{z}$ stained in Congo red reagent. Scale bars: $\mathrm{c}-\mathrm{d}=100$ $\mu \mathrm{m}, \mathrm{g}-\mathrm{h}=50 \mu \mathrm{m}, \mathrm{i}, \mathrm{m}-\mathrm{n}=20 \mu \mathrm{m}, \mathrm{j}-\mathrm{l}, \mathrm{o}-\mathrm{t}=10 \mu \mathrm{m}, \mathrm{u}-\mathrm{Z}=5 \mu \mathrm{m}$.

Known hosts and distribution - on Sticta ambavillaria in Kenya (type locality), Tanzania, Peru, New Guinea (Nannfeldt \& Santesson 1975, Gams et al. 2019).

Notes - Nitschkiopsis stictarum recorded so far found on Sticta ambavillaria (Nannfeldt \& Santesson 1975, Gams et al. 2019). It was transferred as Niesslia stictarum (Tretiach 2002), however no molecular data is available for the N. stictarum. 
Paraniesslia C.K.M. Tsui, K.D. Hyde \& Hodgkiss, Mycologia 93(5): 1002 (2001)

Saprobic on wood. Sexual morph: Ascomata perithecial, solitary or scattered, semi-immersed to superficial, pyriform, globose to subglobose, pale brown to brown, membranaceous, ostioles surrounded by cylindrical, brown to black, septate setae, periphysate. Peridium membranaceous, brown cells of textura epidermoidea on surface view; inner layer composed of brown to hyaline cells of textura angularis to textura prismatica. Paraphyses filiform, septate, evanescent. Asci 8spored, unitunicate, clavate, pedicellate, apex blunt, evanescent. Ascospores uni- or bi-seriate or overlapping, hyaline when young, becoming olivaceous brown, ellipsoidal to fusiform, 1-septate, slightly constricted at the septum, tuberculate, guttulate. Asexual morph: Undetermined (adapted from Tsui et al. 2001).

Notes - The monotypic Paraniesslia was introduced by Tsui et al. (2001) for P. tuberculata. It is similar to Niesslia with setose ascomata and clavate asci, differing from it in the possessing of tuberculate, ellipsoidal ascospores (Tsui et al. 2001). There is no molecular data available for Paraniesslia.

Paraniesslia tuberculata C.K.M. Tsui, K.D. Hyde \& Hodgkiss, Mycologia 93(5): 1002 (2001)

Fig. 33n-o

Facesoffungi number: FoF 10180

Saprobic on wood. Sexual morph: Ascomata perithecial, solitary or scattered, semi-immersed to superficial, pyriform, globose to subglobose, pale brown to brown, membranaceous, ostioles surrounded by cylindrical, brown to black, septate setae, periphysate. Peridium membranaceous, brown cells of textura epidermoidea on surface view; inner layer composed of brown to hyaline cells of textura angularis to textura prismatica. Paraphyses filiform, septate, evanescent. Asci 8spored, unitunicate, clavate, pedicellate, apex blunt, evanescent. Ascospores uni- or bi-seriate or overlapping, hyaline when young, becoming olivaceous brown, ellipsoidal to fusiform, 1-septate, slightly constricted at the septum, tuberculate, guttulate. Asexual morph: Undetermined (adapted from Tsui et al. 2001).

Known hosts and distribution - on submerged wood in China (type locality) (Tsui et al. 2001).

Notes - Paraniesslia tuberculate was collected on submerged wood in China (Tsui et al. 2001). It is similar to Niesslia, but can be differentiated from its olivaceous brown, tuberculate and ellipsoidal ascospores (Tsui et al. 2001).

Pseudohyaloseta Tibpromma \& K.D. Hyde, in Tibpromma et al., Fungal Diversity: 10.1007/s13225-018-0408-6, [113] (2018)

Saprobic on wood or leaves. Sexual morph: Ascomata perithecial, scattered or gregarious, semi-immersed to superficial, globose to subglobose, black, membranaceous, surrounded by cylindrical, hyaline setae with swollen apex, ostiolate, periphysate. Peridium membranaceous, composed of brown to hyaline cells of textura angularis to textura prismatica. Paraphyses filiform, septate, unbranched. Asci 6-8-spored, unitunicate, clavate, pedicellate, apical ring distinct. Ascospores uni- or bi-seriate, hyaline to subhyaline, cylindrical to fusiform, slightly curved, 1septate, slightly constricted at the septum, tuberculate, guttulate, with a mucilaginous sheath. Asexual morph: Undetermined (adapted from Tibpromma et al. 2018).

Notes - The monotypic Pseudohyaloseta was established by Tibpromma et al. (2018) for $P$. pandanicola. This genus is closely related to Niesslia nolinae based on phylogenetic result. However, the latter has different ellipsoidal ascospores without a sheath (Tibpromma et al. 2018). In this study, Pseudohyaloseta is sister to the clade of N. antarctica, N. gamsii (asexual morph) and N. nolinae (100\%ML/1.00BY, Fig. 1), which have ellipsoidal ascospores without a sheath.

Pseudohyaloseta pandanicola Tibpromma \& K.D. Hyde, in Tibpromma et al., Fungal Diversity: 10.1007/s13225-018-0408-6, [113] (2018)

Facesoffungi number: FoF 10181 
Saprobic on wood or leaves. Sexual morph: Ascomata perithecial, scattered or gregarious, semi-immersed to superficial, globose to subglobose, black, membranaceous, surrounded by cylindrical, hyaline setae with swollen apex, ostiolate, periphysate. Peridium membranaceous, composed of brown to hyaline cells of textura angularis to textura prismatica. Paraphyses filiform, septate, unbranched. Asci 6-8-spored, unitunicate, clavate, pedicellate, apical ring distinct. Ascospores uni- or bi-seriate, hyaline to subhyaline, cylindrical to fusiform, slightly curved, 1septate, slightly constricted at the septum, tuberculate, guttulate, with a mucilaginous sheath. Asexual morph: Undetermined (adapted from Tibpromma et al. 2018).

Known hosts and distribution - on dead roots, stems or leaves of Freycinetia and Pandanus in Thailand (type locality) (Tibpromma et al. 2018).

Notes - Pseudohyaloseta pandanicola was first collected on dead roots of Freycinetia javanica, and Pandanus sp. in Thailand (Tibpromma et al. 2018).

\section{Pseudonectriella Petr., Sydowia 13(1-6): 127 (1959)}

Saprobic or parasitic on wood. Sexual morph: Ascomata perithecial, solitary, superficial, turbinate, obpyriform to subglobose, or deep collapsing as cupuliform, 3-8-loculate, dark brown to black, membranaceous, tuberculate, glabrous, ostioles inconspicuous, periphysate. Peridium composed of membranaceous, brown to pale brown to hyaline cells of textura globulosa to textura angularis to textura prismatica. Paraphyses rare, filiform, septate. Asci 8-spored, unitunicate, cylindrical, pedicellate, apex rounded, apical ring absent, evanescent. Ascospores uni- or bi-seriate, hyaline, ellipsoidal to oval, 0-1-septate, smooth-walled, guttulate. Asexual morph: Coelomycetous. Conidiomata superficial, turbinate, obpyriform to subglobose, or deep collapsing as cupuliform, 38-loculate, dark brown to black, membranaceous, tuberculate. Peridium composed of membranaceous, brown to pale brown cells of textura globulosa to textura angularis to textura prismatica, becoming hyaline towards inner conidiogenous region. Conidiophores erect, hyaline, cylindrical to subcylindrical, unbranched. Conidia terminal, oval to ellipsoidal, aseptate, hyaline, smooth-walled, guttulate (adapted from Petrak 1959).

Notes - The monotypic Pseudonectriella is typified by $P$. ahmadii which has black ascomata, cylindrical asci and ellipsoidal ascospores (Petrak 1959). Lumbsch \& Huhndorf (2007) placed this genus in Niessliaceae. However, no sequence data is available for the Pseudonectriella.

Pseudonectriella ahmadii Petr., Sydowia 13(1-6): 128 (1959)

Fig. 36

Facesoffungi number: FoF 10076

Saprobic or parasitic on wood. Sexual morph: Ascomata 430-600 $\mu \mathrm{m}(\bar{x}=500 \mu \mathrm{m}, \mathrm{n}=10)$ diam., perithecial, solitary, superficial, turbinate, obpyriform to subglobose, or deep collapsing as cupuliform, 3-8-loculate, 130-200 $\mu \mathrm{m}(\bar{x}=160 \mu \mathrm{m}, \mathrm{n}=10)$ diam., dark brown to black, membranaceous, tuberculate, glabrous, ostioles inconspicuous, periphysate. Peridium 20-45 $\mu \mathrm{m}$ wide, membranaceous, comprising three layers, outer layer composed of brown to pale brown cells of textura globulosa; middle layer composed of pale brown to hyaline cells of textura angularis; inner layer composed of hyaline cells of textura prismatica. Paraphyses absent. Asci (20-)25-30($35) \times(2.5-) 3-5(-7) \mu \mathrm{m}(\bar{x}=28 \times 4 \mu \mathrm{m}, \mathrm{n}=20), 8$-spored, unitunicate, cylindrical, pedicellate, apex rounded, apical ring absent, evanescent. Ascospores $(2.5-) 3-3.5(-4.5) \times(1-) 1.5-2.5 \mu \mathrm{m}(\bar{x}=$ $3.4 \times 1.8 \mu \mathrm{m}, \mathrm{n}=50$ ), uni- or bi-seriate, hyaline, ellipsoidal to oval, 0-1-septate, smooth-walled, guttulate. Asexual morph: appeared in the same locule with asci or in conidiomata. Conidiomata 130-200 $\mu \mathrm{m}(\bar{x}=160 \mu \mathrm{m}, \mathrm{n}=10)$ diam., superficial, turbinate, obpyriform to subglobose, or deep collapsing as cupuliform, 3-8-loculate, dark brown to black, membranaceous, tuberculate. Peridium 28-45 $\mu \mathrm{m}$ wide, membranaceous, comprising three layers, outer layer composed of brown to pale brown cells of textura globulosa; middle layer composed of pale brown to hyaline cells of textura angularis; inner layer composed of hyaline cells of textura prismatica, towards inner conidiogenous region. Conidiophores 5-8(-12) $\times 0.5-1.5 \mu \mathrm{m}(\bar{x}=7.5 \times 1 \mu \mathrm{m}, \mathrm{n}=20)$, erect, hyaline, cylindrical to subcylindrical, unbranched. Conidia $1-2.5 \times 0.7-1.5 \mu \mathrm{m}(\bar{x}=2 \times 1 \mu \mathrm{m}, \mathrm{n}=$ 50), terminal, oval to globose, aseptate, hyaline, smooth-walled, guttulate. 
Material examined - Pakistan, Lahore, Changa Manga, on branches of Cadaba farinosa, 24 March 1954, S. Ahmad (BPI-1110420, holotype); ibid. (S-F8085, Isotype).

Known hosts and distribution - on wood of Cadaba farinosa (Capparaceae) in Pakistan (type locality) (Petrak 1959).

Notes - Petrak (1959) collected Pseudonectriella ahmadii on the wood of Cadaba in Pakistan and found that its sexual morph is similar to Nectria cinnabarina. In this study, we re-examined the type material and found both mature asci and conidiophores producing conidia in the same locule (Fig. $36 \mathrm{u}$ ).

Pseudorhynchia Höhn., Sber. Akad. Wiss. Wien, Math.-naturw. Kl., Abt. 1 118: 1206 (1909)

Saprobic leaves or stems. Sexual morph: Ascomata perithecial, scattered or gregarious, semiimmersed to superficial, globose to subglobose, brown or black, membranaceous, tuberculate, inconspicuous ostioles surrounded by long setae. Setae composed of filiform, brown, septate, tapering hyphae, with metallic iridescence. Peridium composed of membranaceous, brown to hyaline cells of textura epidermoidea to textura angularis to textura prismatica. Paraphyses absent. Asci 8-spored, unitunicate, clavate, pedicellate, apex rounded, apical ring indistinct, evanescent. Ascospores bi-seriate, hyaline, fusiform, straight or slightly curved, 0-1-septate, faintly striate, guttulate. Asexual morph: Undetermined (adapted from Penzig \& Saccardo 1897, Dulymamode et al. 2001).

Notes - Pseudorhynchia was established by von Höhnel (1909a) based on Ceratostomella polyrrhyncha. The second species, P. mauritiana, was collected from leaves of Cordemoya integrifolia in Mauritius. They are characterized by ascomata with ostioles surrounded by long setae and fusiform ascospores (Penzig \& Saccardo 1897, Dulymamode et al. 2001). Lumbsch \& Huhndorf (2007) placed this genus in Niessliaceae, but no sequence data is available.

Pseudorhynchia polyrrhyncha (Penz. \& Sacc.) Höhn., Sber. Akad. Wiss. Wien, Math.-naturw. Kl., Abt. 1 118: 1206 (1909)

Fig. 37

Basionym - Ceratostomella polyrrhyncha Penz. \& Sacc., Malpighia 11(9-10): 408 (1897)

Facesoffungi number: FoF 10077

Saprobic leaves or stems. Sexual morph: Ascomata 110-170 $\mu \mathrm{m}(\bar{x}=140 \mu \mathrm{m}, \mathrm{n}=10)$, perithecial, scattered or gregarious, semi-immersed to superficial, globose to subglobose, brown or black, membranaceous, tuberculate, inconspicuous ostioles surrounded by long setae. Setae 420$500 \times 25-55 \mu \mathrm{m}$, composed of filiform, brown, septate, tapering hyphae, with metallic iridescence. Peridium 15-45 $\mu \mathrm{m}$ wide, membranaceous, comprising three layers, brown cells of textura epidermoidea on surface view; middle layer composed of brown to olivaceous brown cells of textura angularis; inner layer composed of hyaline cells of textura prismatica. Paraphyses absent. Asci (50-)65-80(-90) $\times(7-) 9-12(-15) \mu \mathrm{m}(\bar{x}=70 \times 10 \mu \mathrm{m}, \mathrm{n}=20), 8$-spored, unitunicate, clavate, pedicellate, apex rounded, apical ring indistinct, evanescent. Ascospores (15-)17-20(-25) $\times(2.5-$ )3-5(-5.5) $\mu \mathrm{m}(\bar{x}=18 \times 4 \mu \mathrm{m}, \mathrm{n}=50)$, bi-seriate, hyaline, fusiform, straight or slightly curved, 0 1-septate, faintly striate, guttulate. Asexual morph: Undetermined.

Material examined - Venezuela, Edo. Miranda, Guatopo National Park, alt. 500-600 m, $10^{\circ} 03^{\prime} \mathrm{N}, 66^{\circ} 26^{\prime} \mathrm{W}$, Trail between Agua Blanca and La Cruceta, on dead leaves of Heliconia sp., 27-30 November 1990, G.J. Samuels, B. Hein and S.M. Huhndorf (BPI-802960).

Known hosts and distribution - on decayed leaves or stems of Elettaria in Indonesia (type locality) and Venezuela (Penzig \& Saccardo 1897).

Notes - The type material is unable to obtain. Therefore, we re-examined the authentic material collected by Samuels, Hein and Huhndorf in Venezuela.

Rosasphaeria Jaklitsch \& Voglmayr, Fungal Diversity 52(1): 93 (2012)

Saprobic on twigs of Rosa. Sexual morph: Ascomata perithecial, solitary or scattered, immersed, pyriform to subglobose, black, membranaceous, glabrous, ostiolate, periphysate. Peridium composed of membranaceous, brown to hyaline cells of textura angularis to textura 
prismatica. Paraphyses absent. Asci 8-spored, unitunicate, cylindrical to clavate, pedicellate or sessile, apex rounded, apical ring indistinct, evanescent. Ascospores bi-seriate, hyaline, cylindrical to fusiform, straight or slightly curved, 1-septate, smooth-walled, guttulate. Asexual morph: Hyphomycetous. Mycelium white to orange, superficial, effused. Conidiophores mononematous, macronematous, hyaline, unbranched, cylindrical to oblong, aseptate. Conidia terminal, cylindrical, usually curved, 1-septate, hyaline, smooth-walled, guttulate (adapted from Jaklitsch \& Voglmayr 2012).
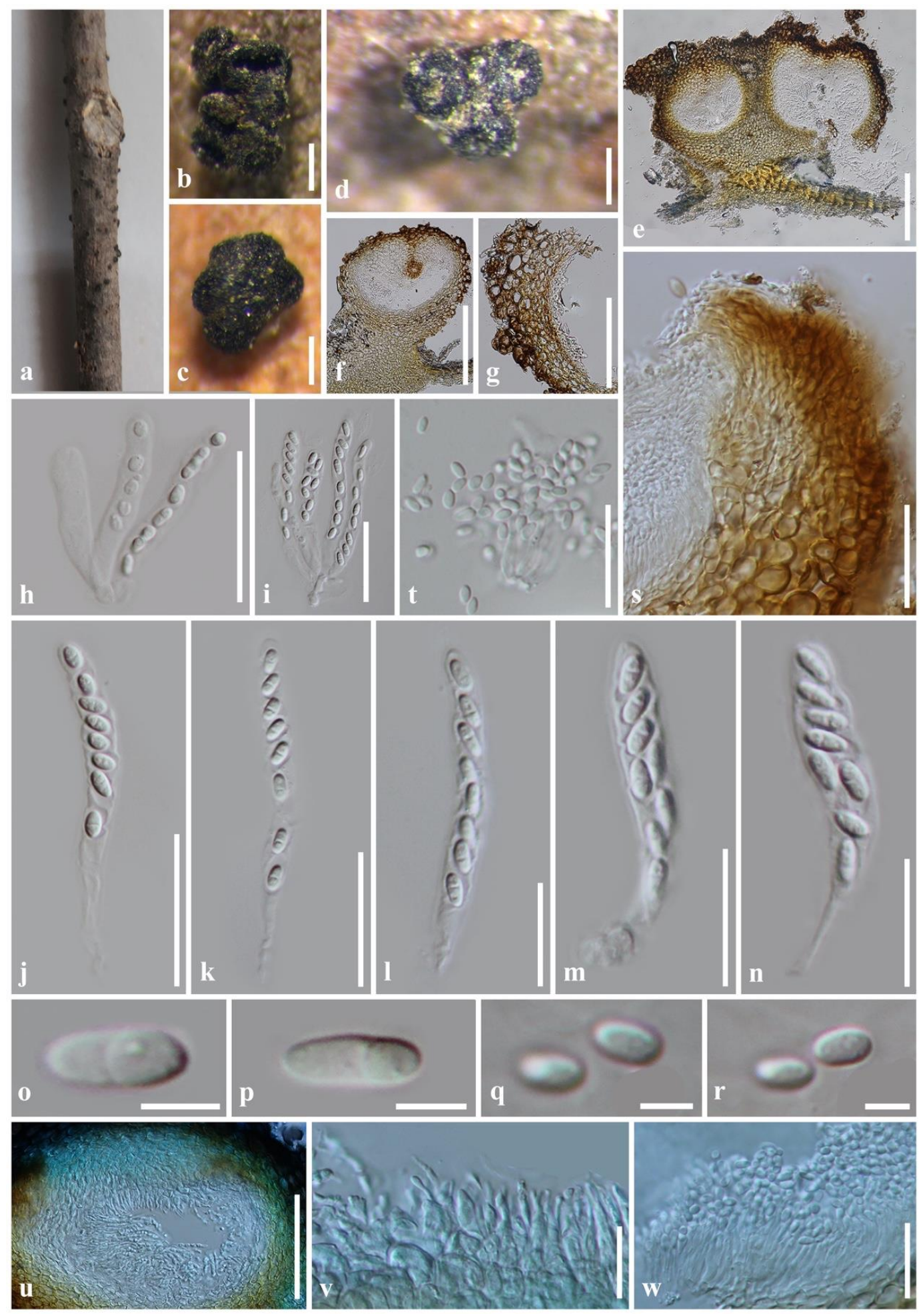

Figure 36 - Pseudonectriella ahmadii: a-c, e, q-r, s, w (BPI-1110420, holotype); d, f-p, t-v (SF8085, Isotype). a Material. b-d Ascomata on the host. e-f Ascomata cross section. g Peridium of 
ascomata. $\mathrm{h}-\mathrm{n}$ Asci. o-r Ascospores. s Peridium of conidiomata. t Conidiophores and conidia. $\mathrm{u}$ Mature asci and conidiophores in the same locule. $\mathrm{v}$ Wall cells of ascomata towards inner conidiogenous region (enlarged view of the conidiophores part of $\mathrm{u}$ ). $\mathrm{w}$ Conidiophores and conidia in conidiomata. Notes: $\mathrm{u}-\mathrm{w}$ stained in cotton blue reagent. Scale bars: $\mathrm{b}-\mathrm{d}=200 \mu \mathrm{m}$, $\mathrm{e}-\mathrm{f}=100$ $\mu \mathrm{m}, \mathrm{g}, \mathrm{u}=50 \mu \mathrm{m}, \mathrm{h}-\mathrm{k}, \mathrm{s}=20 \mu \mathrm{m}, \mathrm{l}-\mathrm{n}, \mathrm{t}, \mathrm{v}-\mathrm{w}=10 \mu \mathrm{m}, \mathrm{o}-\mathrm{r}=2 \mu \mathrm{m}$.
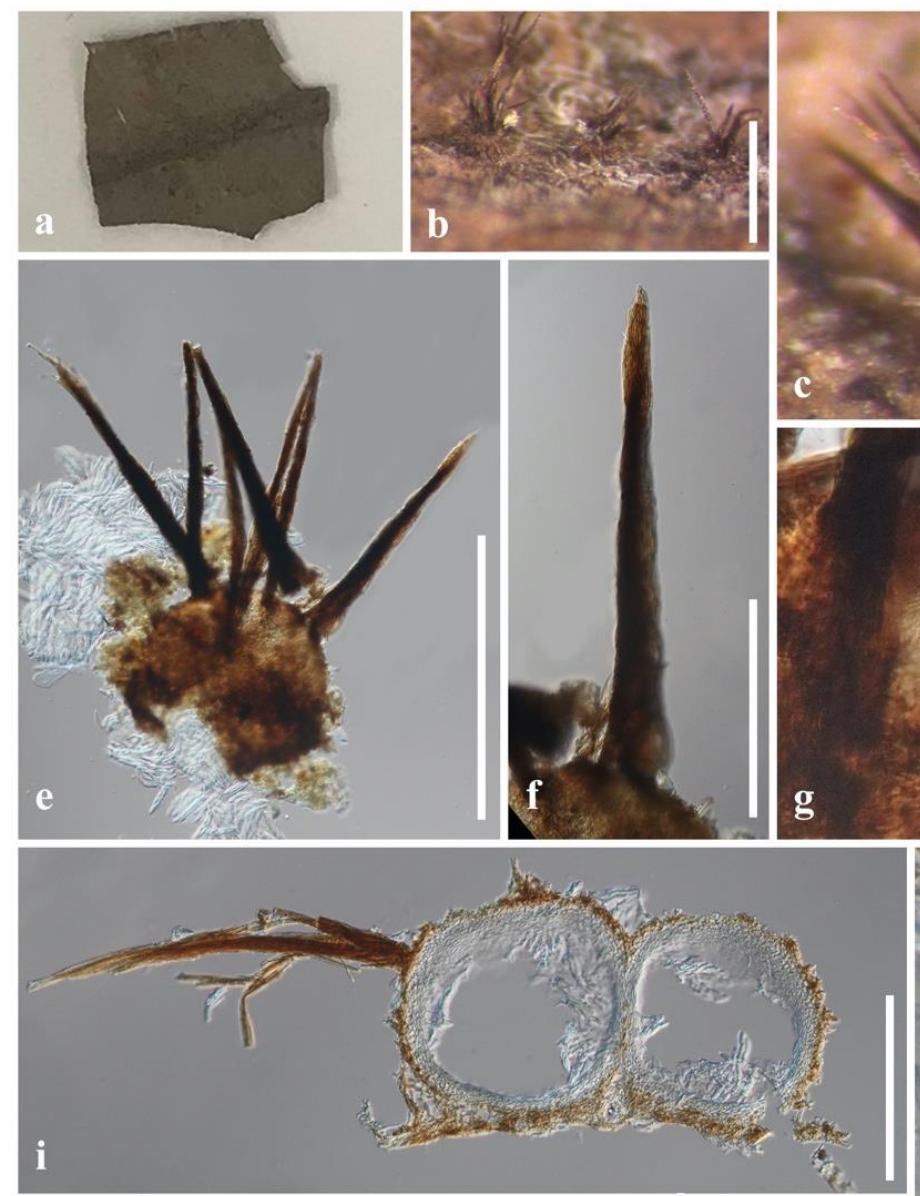
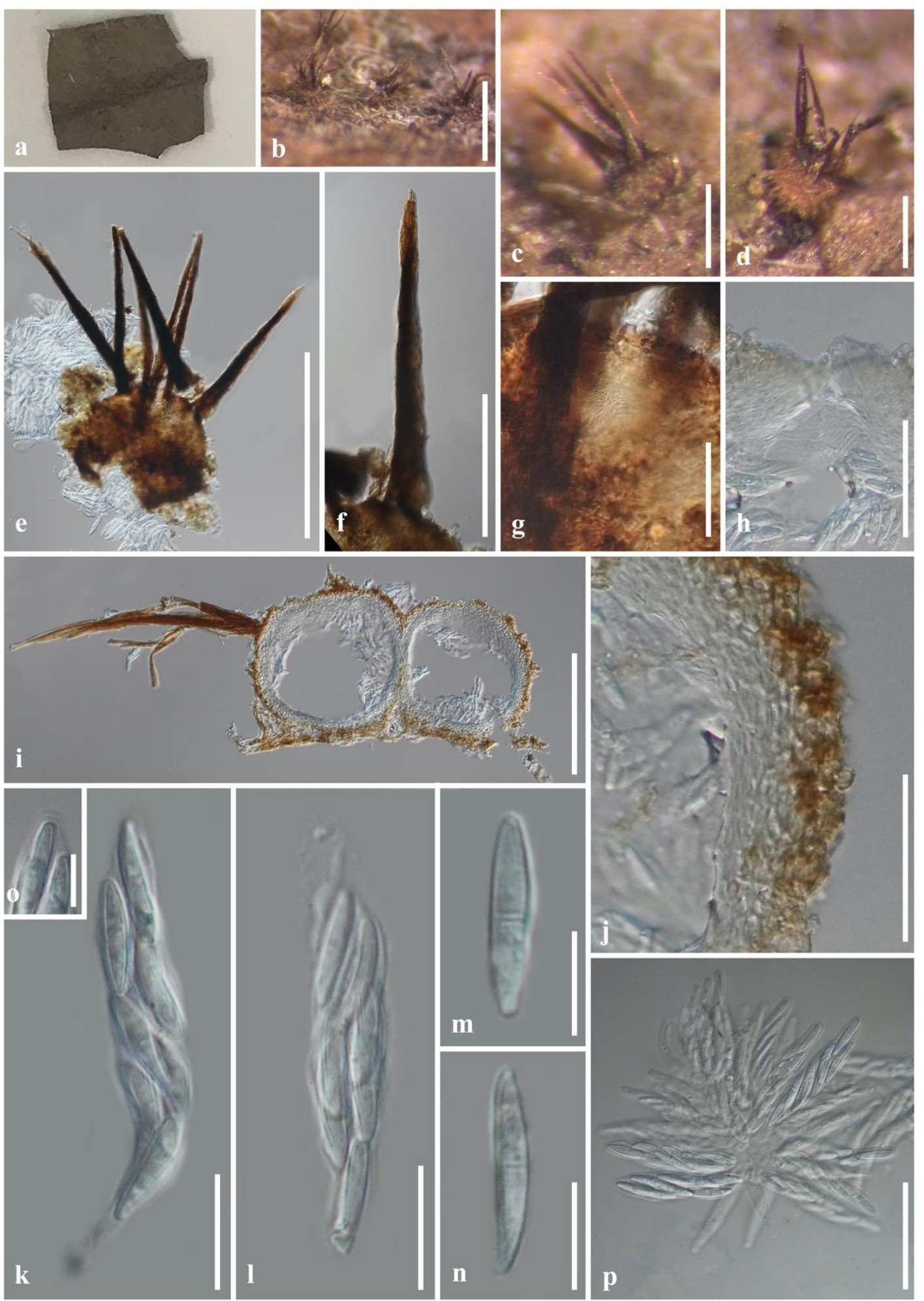

Figure 37 - Pseudorhynchia polyrrhyncha: (BPI-802960). a Material. b-d Ascomata on the host. e Squashed ascoma. f Seta. g-h Ostiole. i Ascomata cross section. j Peridium. k-1, p Asci. $\mathrm{m}-\mathrm{n}$ Ascospores. o Apical ascus. Scale bars: $\mathrm{b}, \mathrm{e}=500 \mu \mathrm{m}, \mathrm{c}-\mathrm{d}, \mathrm{f}, \mathrm{i}=200 \mu \mathrm{m}, \mathrm{g}-\mathrm{h}, \mathrm{j}, \mathrm{p}=50 \mu \mathrm{m}$, $\mathrm{k}-\mathrm{l}=20 \mu \mathrm{m}, \mathrm{m}-\mathrm{O}=10 \mu \mathrm{m}$. 
Notes - The monotypic Rosasphaeria was established by Jaklitsch \& Voglmayr (2012) based on Stigmatea moravica. This genus was placed in Niessliaceae based on phylogenetic result (Jaklitsch \& Voglmayr 2012). In this study, Rosasphaeria is sister to Neoeucasphaeria (Fig. 1), differing from the latter that has ellipsoidal, aseptate and hyaline conidia (Crous et al. 2018).

Rosasphaeria moravica (Petr.) Jaklitsch \& Voglmayr, Fungal Diversity 52(1): 93 (2012) Fig. 38

Basionym - Stigmatea moravica Petr., Annls mycol. 12(5): 473 (1914)

Facesoffungi number: FoF 10078

Saprobic on twigs of Rosa. Sexual morph: Ascomata 110-220 $\mu \mathrm{m}(\bar{x}=160 \mu \mathrm{m}, \mathrm{n}=10)$ diam., perithecial, solitary or scattered, immersed, pyriform to subglobose, black, membranaceous, glabrous, ostiolate, periphysate. Peridium 10-30 $\mu \mathrm{m}$ wide, composed of membranaceous, brown to hyaline cells of textura angularis to textura prismatica. Paraphyses absent. Asci (50-)67-82(-90) $\times$ $(5-) 7-8(-12) \mu \mathrm{m}(\bar{x}=75 \times 7.5 \mu \mathrm{m}, \mathrm{n}=20), 8$-spored, unitunicate, cylindrical to clavate, pedicellate or sessile, apex rounded, apical ring indistinct, evanescent. Ascospores $(15-) 20-25(-30) \times(2-) 2.5-$ $4.5(-5) \mu \mathrm{m}(\bar{x}=22 \times 3.5 \mu \mathrm{m}, \mathrm{n}=50)$, bi-seriate, hyaline, cylindrical to fusiform, straight or slightly curved, 1-septate, smooth-walled, guttulate. Asexual morph: Hyphomycetous. Mycelium white to orange, superficial, effused. Conidiophores mononematous, macronematous, hyaline, unbranched, cylindrical to oblong, aseptate. Conidia terminal, cylindrical, usually curved, 1-septate, hyaline, smooth-walled, guttulate (adapted from Jaklitsch \& Voglmayr 2012).

Material examined - Czech Republic, Olomoucky kraj, M. Weisskirchen, Hrabuvka, on dead twigs of Rosa canina, 18 April 1912, F. Petrak (S-F86647, holotype).

Known hosts and distribution - on decayed twigs of Rosa canina (Rosaceae) in Austria, Czech Republic (type locality) and Sweden (Jaklitsch \& Voglmayr 2012).

Notes - Jaklitsch \& Voglmayr (2012) introduced Rosasphaeria moravica in Niessliaceae. This species is sister to Neoeucasphaeria eucalypti and nests in Niessliaceae (Jaklitsch \& Voglmayr 2012, this study, Fig. 1).

Taiwanascus Sivan. \& H.S. Chang, Mycol. Res. 101(2): 176 (1997)

Saprobic on wood. Sexual morph: Ascomata cleistothecial, solitary, superficial, globose, brown, membranaceous, tuberculate, with setae. Setae cylindrical, aseptate, brown, straight, smooth-walled, with branched ends. Peridium composed of membranaceous, olivaceous brown cells of textura angularis. Paraphyses absent. Asci 4-spored, unitunicate, cylindrical, pedicellate, apex rounded, apical ring absent, evanescent. Ascospores bi-seriate to overlapping, hyaline, fusiform or ellipsoidal, straight or slightly curved, aseptate or 1-septate, smooth-walled, guttulate. Asexual morph: Undetermined (adapted from Sivanesan \& Chang 1997, Rajeshkumar \& Rossman 2013).

Notes - Taiwanascus was introduced by Sivanesan \& Chang (1997) for T. tetrasporus. Rajeshkumar \& Rossman (2013) subsequently introduced second species, T. samuelsii, from India. These species have cleistothecial ascomata with special branched setae, but the former has fusiform ascospores and the latter has ellipsoidal (Sivanesan \& Chang 1997, Rajeshkumar \& Rossman 2013). There is no sequence data available for this genus.

Taiwanascus tetrasporus Sivan. \& H.S. Chang, Mycol. Res. 101(2): 176 (1997)

Fig. 39

Facesoffungi number: FoF 10079

Saprobic on wood. Sexual morph: Ascomata 94-250 $\mu \mathrm{m}(\bar{x}=120 \mu \mathrm{m}, \mathrm{n}=10)$ diam., cleistothecial, solitary, superficial, globose, brown, membranaceous, tuberculate, with setae. Setae 16-32 $\times 3-7 \mu \mathrm{m}(\bar{x}=25 \times 5 \mu \mathrm{m}, \mathrm{n}=20)$, cylindrical, aseptate, brown, straight, smooth-walled, with 2-8-branched ends, each vertex has 6-8 tiny denticles. Peridium 5-10 $\mu \mathrm{m}$ wide, composed of membranaceous, olivaceous brown cells of textura angularis. Paraphyses absent. Asci (15-)20$25(-28) \times 4-6 \mu \mathrm{m}(\bar{x}=23 \times 5 \mu \mathrm{m}, \mathrm{n}=20)$ at ascospore-bearing part, 4-spored, unitunicate, cylindrical, pedicellate, apex rounded, apical ring absent, evanescent. Ascospores (14-)18-22 $\times$ $(0.6-) 1-1.6 \mu \mathrm{m}(\bar{x}=20 \times 1.2 \mu \mathrm{m}, \mathrm{n}=50)$, overlapping, hyaline, fusiform, straight or slightly 
curved, aseptate, rarely 1-septate, smooth-walled, guttulate. Asexual morph: Undetermined (adapted from Sivanesan \& Chang 1997).

Material examined - China, Taiwan, Taipei, Wulai, on dead wood, 18 January 1994, H.S. Chang (IMI-364835, holotype).
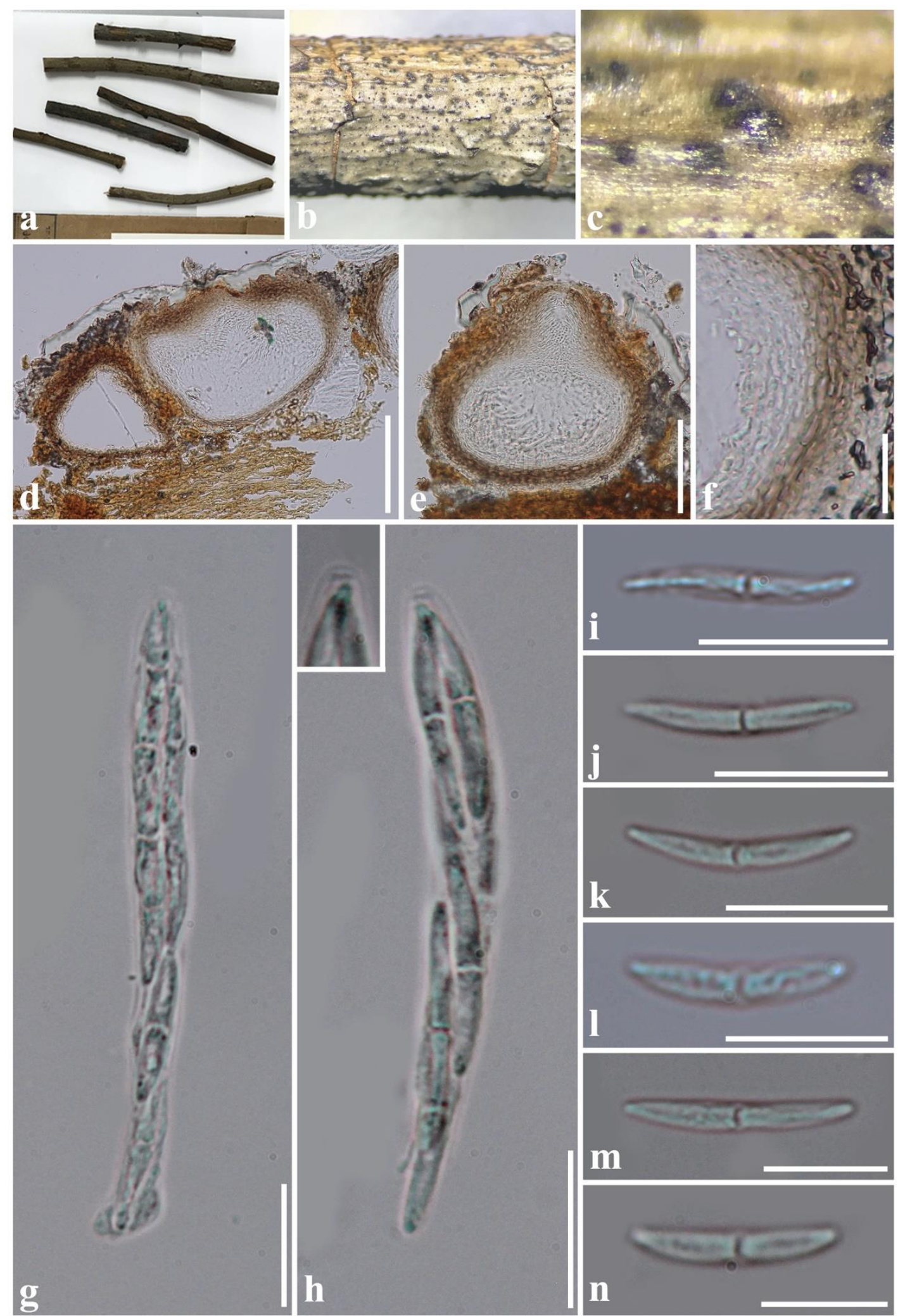

Figure 38 - Rosasphaeria moravica: (S-F86647, holotype). a Material. b Ascomata on the host. c Immersed ascomata. d-e Ascomata cross section. f Peridium. g-h Asci (h enlarged apical ring). i-n Ascospores. Scale bars: $\mathrm{d}-\mathrm{e}=100 \mu \mathrm{m}, \mathrm{f}-\mathrm{n}=20 \mu \mathrm{m}$. 

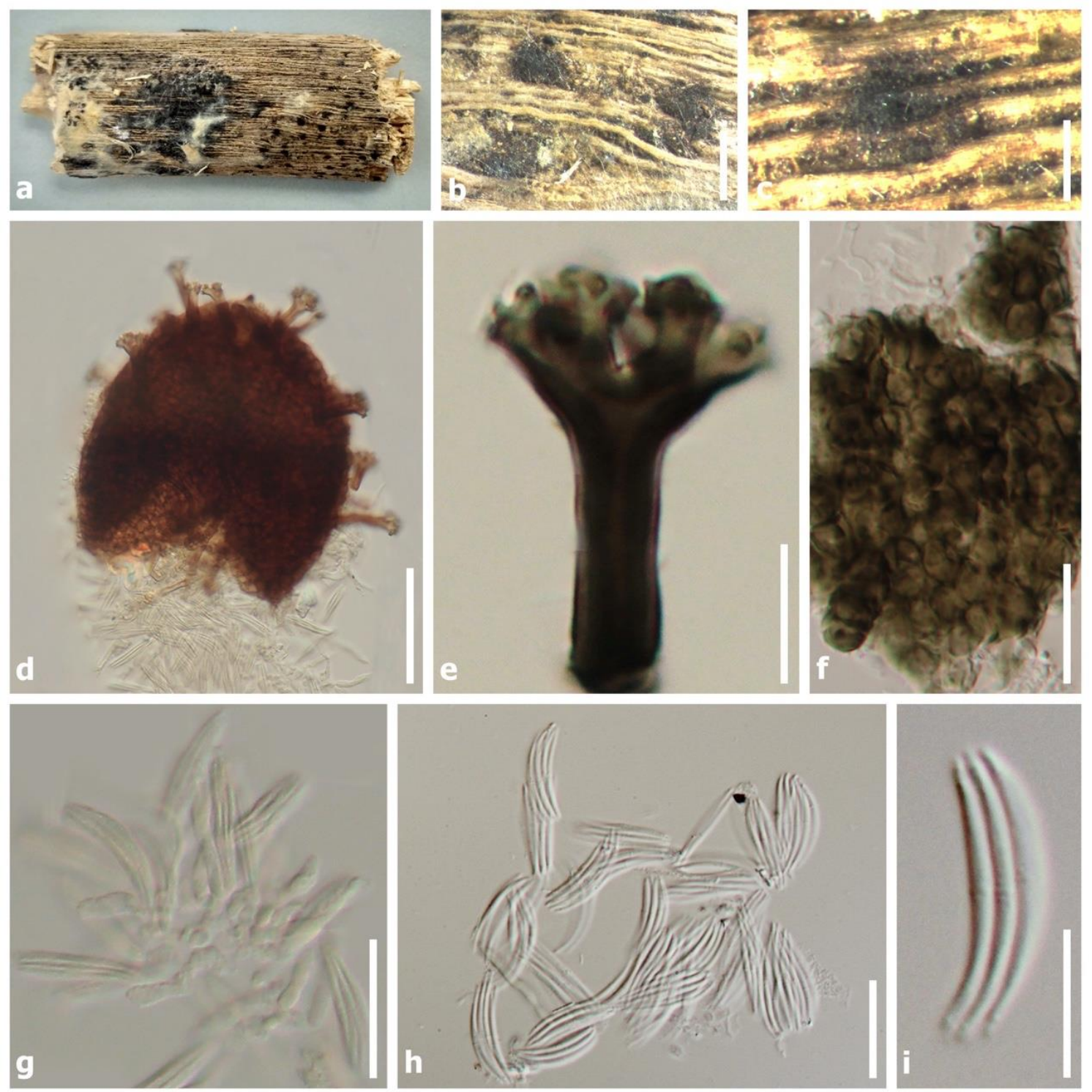

Figure 39 - Taiwanascus tetrasporus: (IMI-364835, holotype). a Material. b-c Ascomata on the host. $d$ Squashed ascoma. e Seta. f Surface view of ascoma. g-h Asci. i Ascospores. Scale bars: $b=$ $1 \mathrm{~mm}, \mathrm{c}=500 \mu \mathrm{m}, \mathrm{d}=50 \mu \mathrm{m}, \mathrm{f}-\mathrm{h}=20 \mu \mathrm{m}, \mathrm{e} . \mathrm{i}=10 \mu \mathrm{m}$.

Known hosts and distribution - on decayed wood in China (type locality) (Sivanesan \& Chang 1997).

Notes - Sivanesan \& Chang (1997) introduced Taiwanascaceae based on Taiwanascus tetrasporus and Samuels \& Barr (1997) treated this family as a synonym of Niessliaceae. Therefore, T. tetrasporus was placed in Niessliaceae, but sequence data is not available.

Trichosphaerella E. Bommer, M. Rousseau \& Sacc., in Bommer \& Rousseau, Bull. Soc. R. Bot. Belg. 29(no. 1): 261 (1890)

Saprobic or parasitic on wood or stems, sometimes fungicolous. Sexual morph: Ascomata perithecial, scattered or gregarious, superficial, sometimes sitting on a subiculum, globose to subglobose, brown, membranaceous, glabrous or with brown setae, ostiolate, periphysate. Peridium composed of membranaceous, brown to hyaline cells of textura angularis to textura prismatica. Paraphyses absent. Asci 8-spored, unitunicate, cylindrical to clavate, pedicellate or sessile, apex rounded, apical ring indistinct or absent, evanescent. Ascospores uni- or bi-seriate or overlapping, hyaline, ellipsoidal to fusiform, straight or slightly curved, usually 1-septate, constricted at the septum to form ascoconidia, guttulate. Ascoconidia globose to subglobose, hyaline, smooth-walled 
or spinulose or verrucose, sometimes becoming red in Melzer's reagent. Asexual morph: Hyphomycetous. Conidiophores mononematous, macronematous, hyaline, branched, straight or curved. Conidia globose to ellipsoidal, usually aseptate, hyaline, smooth-walled or verrucose (adapted from Müller \& Samuels 1982, Samuels 1983, Samuels \& Barr 1997).

Notes - Trichosphaerella was introduced by Bommer \& Rousseau (1890) for T. decipiens. von Höhnel (1903) subsequently introduced Bresadolella with B. aurea. However, Samuels \& Barr (1997) treated $B$. aurea as a synonym of $T$. decipiens based on similar morphology and associated with acremonium-like fungi. Lombard et al. (2015) sequenced the T. ceratophora which is sister to Hyaloseta nnolinae in Niessliaceae. In this study, T. ceratophora is sister to Valetoniellopsis, differing from the latter that has glabrous ascomata with ellipsoidal ascospores. However, there is no molecular data for the type T. decipiens.

Trichosphaerella decipiens Sacc., E. Bommer \& M. Rousseau, in Bommer \& Rousseau, Bull. Soc. R. Bot. Belg. 29(no. 1): 261 (1890)

Fig. 40

Facesoffungi number: FoF 10080

Saprobic or parasitic on wood or stems, sometimes fungicolous. Sexual morph: Ascomata perithecial, scattered or gregarious, superficial, sitting on a subiculum with hyaline, coiled, verrucose, septate hyphae, globose to subglobose, brown, membranaceous, with brown, cylindrical, tapering setae, 74-120 ×9-16 $\mu \mathrm{m}$, ostiolate, periphysate. Peridium composed of membranaceous, brown to hyaline cells of textura angularis to textura prismatica. Paraphyses absent. Asci 24-28($32) \times 3-5 \mu \mathrm{m}(\bar{x}=27 \times 4.5 \mu \mathrm{m}, \mathrm{n}=20), 8$-spored, unitunicate, cylindrical to clavate, pedicellate or sessile, apex rounded, apical ring indistinct or absent, evanescent. Ascospores bi-seriate, hyaline, ellipsoidal to fusiform, straight or slightly curved, 1-septate, constricted at the septum to form ascoconidia, guttulate. Ascoconidia globose to subglobose, hyaline, verrucose. Asexual morph: Hyphomycetous. Conidiophores mononematous, macronematous, hyaline, branched, straight. Conidia terminal, oval to ellipsoidal, aseptate, hyaline, smooth-walled (adapted from Bommer \& Rousseau 1890, Höhnel 1903, Samuels \& Barr 1997).

Material examined - Austria, Niederösterreich, Pressbaum, on decayed wood of Fagus, September 1903, v. Höhnel (S-F10868; S-F10869, slide of isotype of Bresadolella aurea).

Known hosts and distribution - on wood or basidiomycete in Austria, Belgium (type locality), Canada, Estonia, Guyana and Luxembourg (von Höhnel 1903, Samuels \& Barr 1997).

Notes - Trichosphaerella decipiens was collected on decorticated brahces of Fagus sylvatica in Belgium (Bommer \& Rousseau 1890). Afterwards, von Höhnel (1903) introduced Bresadolella for B. aurea collected on decayed wood of Fagus in Austria. Samuels \& Barr (1997) accepted B. aurea as a synonym of $T$. decipiens based on similar characteristics and obtained its culture from a material made in Guiana. However, there is no sequence data available for $T$. decipiens.

Valetoniella Höhn., Sber. Akad. Wiss. Wien, Math.-naturw. Kl., Abt. 1 118: 1499 (1909)

Saprobic on wood. Sexual morph: Ascomata perithecial, solitary or scattered, superficial on decorticated wood, sometimes sitting on a subiculum, globose to subglobose, translucent and pale brown when fresh, brown or black when dry, membranaceous, tuberculate, ostiolate, periphysate, collapsing when dry. Setae cylindrical, brown, with several conical, brown to pale brown ornamentals at apex. Peridium composed of membranaceous, yellow or pale brown to hyaline cells of textura angularis to textura prismatica. Paraphyses absent. Asci 8-spored, unitunicate, clavate, pedicellate, apex rounded, apical ring absent, evanescent. Ascospores bi-seriate or overlapping, hyaline, usually becoming red in Melzer's reagent, ellipsoidal or fusiform, 1-septate, smoothwalled, faintly striate, guttulate. Asexual morph: Undetermined (adapted from von Höhnel 1909b, Samuels \& Barr 1997).

Notes - Valetoniella was established by von Höhnel (1909b) for V. crucipila, which was found on decorticated wood and accompanied Nectria species. Afterwards, Samuels \& Barr (1997) introduced V. claviornata and V. pauciornata based on their ascomata that have obvious setae with several conical ornamentals at apex, but no molecular data is available for the Valetoniella. 


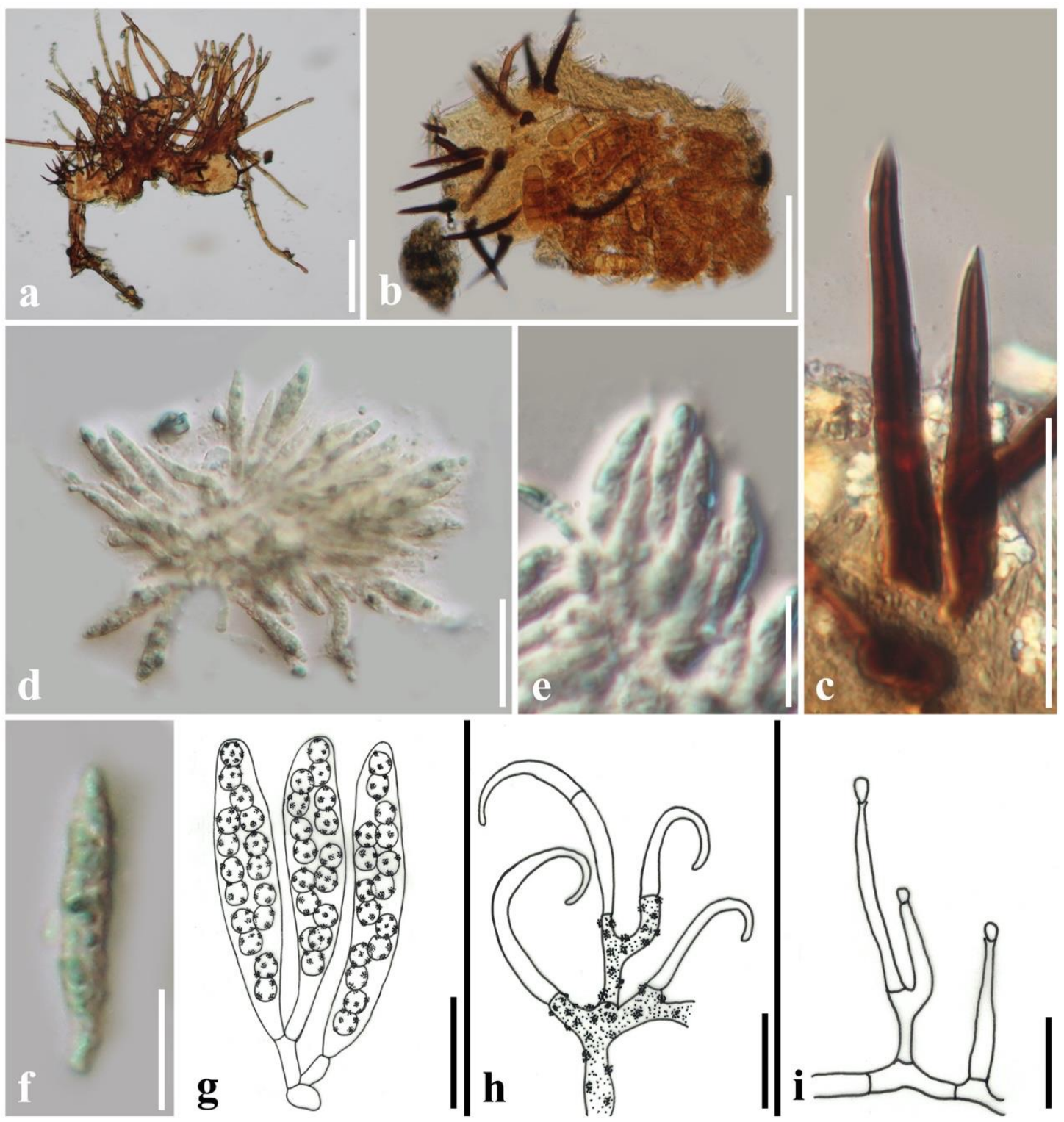

Figure 40 - Trichosphaerella decipiens (= Bresadolella aurea): b-c, e-f (S-F10868, isotype); a, d (S-F10869, isotype); g-i (redrawn from Samuels \& Barr 1997). a-b Squashed ascoma. c Seta. $\mathrm{d}-\mathrm{g}$ Asci ( $\mathrm{g}$ ascoconidia in asci). h Hyphae of subiculum. i Conidiophores and conidia. - Scale bars: $\mathrm{a}=200 \mu \mathrm{m}, \mathrm{b}=100 \mu \mathrm{m}, \mathrm{c}=50 \mu \mathrm{m}, \mathrm{d}-\mathrm{e}=20 \mu \mathrm{m}, \mathrm{f}-\mathrm{i}=10 \mu \mathrm{m}$.

Valetoniella crucipila Höhn., Sber. Akad. Wiss. Wien, Math.-naturw. Kl., Abt. 1 118: 1500 (1909)

Fig. 41

Facesoffungi number: FoF 10081

Saprobic on wood. Sexual morph: Ascomata 160-290 $\mu \mathrm{m}(\bar{x}=240 \mu \mathrm{m}, \mathrm{n}=10)$, perithecial, solitary or scattered, superficial on decorticated wood, sometimes sitting on a subiculum, globose to subglobose, translucent and pale brown when fresh, brown or black when dry, membranaceous, tuberculate, ostiolate, periphysate, collapsing when dry. Setae 35-45 $\times 5-8 \mu \mathrm{m}(\bar{x}=40 \times 6 \mu \mathrm{m}, \mathrm{n}=$ 20 ), cylindrical, brown, with 2-6 conical, brown to pale brown ornamentals at apex. Peridium 25$35 \mu \mathrm{m}$ wide, membranaceous, comprising two layers, outer layer composed of yellow or pale brown cells of textura angularis; inner layer composed of hyaline cells of textura prismatica. Paraphyses absent. Asci (35-)42-46(-60) $\times(7-) 8-10 \mu \mathrm{m}(\bar{x}=45 \times 9 \mu \mathrm{m}, \mathrm{n}=20)$, 8-spored, unitunicate, clavate, pedicellate, apex rounded, apical ring absent, evanescent. Ascospores (7.5-)8$10(-12) \times(3-) 3.5-4.5(-5.2) \mu \mathrm{m}(\bar{x}=9 \times 4 \mu \mathrm{m}, \mathrm{n}=50)$, bi-seriate or overlapping, hyaline, usually 
becoming red in Melzer's reagent, ellipsoidal or fusiform, 1-septate, smooth-walled, faintly striate, guttulate. Asexual morph: Undetermined (adapted from von Höhnel 1909b, Samuels \& Barr 1997).

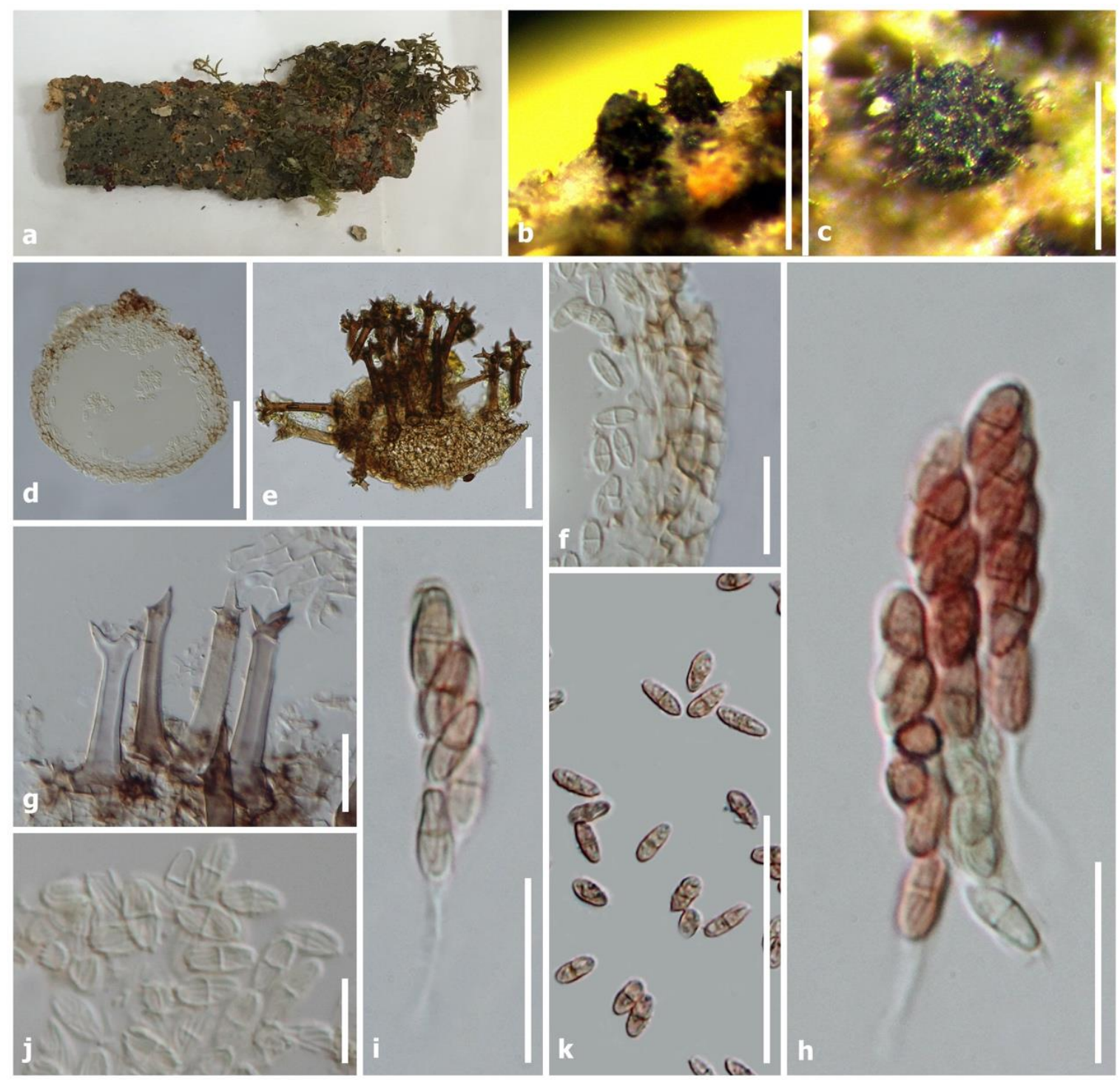

Figure 41 - Valetoniella crucipila: a-b, d, fj (PDD-41743); c, e, k (PDD-50069). a Material. b-c Ascomata on the host. d Ascoma cross section. e Squashed ascoma. f Peridium. g Setae. h-i Asci. j-k Ascospores. Notes: d. f. j from Permanent slide; $\mathrm{h}-\mathrm{i}$, $\mathrm{k}$ stained in Melzer's reagent. Scale bars: $b=500 \mu \mathrm{m}, \mathrm{c}=200 \mu \mathrm{m}, \mathrm{d}=100 \mu \mathrm{m}, \mathrm{e}, \mathrm{k}=50 \mu \mathrm{m}, \mathrm{f}-\mathrm{i}=20 \mu \mathrm{m}, \mathrm{j}=10 \mu \mathrm{m}$.

Material examined - New Zealand, Auckland, Titirangi beach reserve, on ascomata of Nectria haematococca and N. mammoidea, 18 September 1980, G.J. Samuels and P.R. Johnston (PDD-41743); New Zealand, Southland, Catlins state Forest Park, lake Wilkie, on ascomata of Nectria westlandica, 18 April 1985, G.J. Samuels, P.K. Buchanan and L.M. Kohn (PDD-50069).

Known hosts and distribution - on decayed wood and usually accompanied Nectria species in Guyana, Indonesia (type locality), New Zealand, Puerto Rico and Venezuela (von Höhnel 1909b, Samuels \& Barr 1997).

Notes - Valetoniella crucipila was first collected on decorticated wood of Albizia moluccana and accompanied Nectria species (von Höhnel 1909b). Subsequently, Samuels (1983) redescribed this species from New Zealand. Then, Samuels \& Barr (1997) noted that it has been recollected in Guyana, Puerto Rico and Venezuela. This species is characterized by ascomata with special setae, clavate asci and ellipsoidal ascospores that turn red in Melzer's reagent (von Höhnel 1909b, 
Samuels 1983, Samuels \& Barr 1997). In this study, the type material is unable to obtain, thus, we re-examined the authentic materials collected from New Zealand.

\section{Valetoniellopsis Samuels \& M.E. Barr, Can. J. Bot. 75(12): 2175 (1998) [1997]}

Saprobic on leaves. Sexual morph: Ascomata perithecial, solitary or scattered, superficial, globose to subglobose, or collapsing as cupuliform, reddish brown or brown, multiloculated, membranaceous, tuberculate, glabrous or with brown, septate, lax setae at apex, ostiolate, periphysate. Peridium composed of membranaceous, brown to hyaline cells of textura angularis to textura prismatica. Paraphyses absent. Asci 8-spored, unitunicate, clavate, pedicellate or sessile, apex rounded or blunt, apical ring absent, evanescent. Ascospores uni- or bi-seriate, hyaline, cylindrical to oblong, straight or slightly curved, 1-septate, smooth-walled, guttulate. Asexual morph: Hyphomycetous. Conidiophores mononematous, macronematous, hyaline, unbranched, straight. Conidia terminal, ellipsoidal, aseptate, hyaline, smooth-walled, guttulate (adapted from Samuels \& Barr 1997).

Notes - The monotypic Valetoniellopsis is typified by $V$. laxa and placed in Niessliaceae (Samuels \& Barr 1997). It is similar to Circinoniesslia with setose ascomata and acremonium-like asexual morph (Samuels \& Barr 1997). Subsequently, the type $V$. laxa (CBS:191.97) was sequenced and nested in Niessliaceae (Tang et al. 2007, Vu et al. 2019). In this study, Valetoniellopsis is sister to Trichosphaerella in Niessliaceae (Fig. 1).

Valetoniellopsis laxa Samuels \& M.E. Barr, Can. J. Bot. 75(12): 2175 (1998) [1997]

Fig. 42

Facesoffungi number: FoF 10082

Saprobic on leaves. Sexual morph: Ascomata (50-)100-500(-700) $\mu \mathrm{m}(\bar{x}=370 \mu \mathrm{m}, \mathrm{n}=10)$, perithecial, solitary or scattered, superficial, globose to subglobose, or collapsing as cupuliform, reddish brown or brown to black, multiloculated, membranaceous, tuberculate, glabrous or with brown, septate, lax setae at apex, ostiolate, periphysate. Peridium 18-85 $\mu \mathrm{m}$ wide, membranaceous, comprised of two layers, outer layer composed of brown cells of textura angularis; inner layer composed of hyaline cells of textura prismatica. Paraphyses absent. Asci (18-)24-28(-32) $\times(5-$ )6-7.5(-8.5) $\mu \mathrm{m}(\bar{x}=25 \times 6.5 \mu \mathrm{m}, \mathrm{n}=20), 8$-spored, unitunicate, clavate, pedicellate or sessile, apex rounded or blunt, apical ring absent, evanescent. Ascospores (5-)5.5-6.5(-8) $\times(1.5-) 2-2.5$ $\mu \mathrm{m}(\bar{x}=6 \times 2.2 \mu \mathrm{m}, \mathrm{n}=50)$, uni- or bi-seriate, hyaline, cylindrical to oblong, straight or slightly curved, 0-1-septate, smooth-walled, guttulate. Asexual morph: Hyphomycetous. Conidiophores mononematous, macronematous, hyaline, unbranched, straight. Conidia terminal, ellipsoidal, aseptate, hyaline, smooth-walled, guttulate (adapted from Samuels \& Barr 1997).

Material examined - USA, Louisiana, Iberia Parish, Avery Island, Jungle Garden, on dead leaves of palm, 16 August 1996, G.J. Samuels, M. Blackwell, M. Camara (BPI-748357, holotype).

Known hosts and distribution - on dead rachis of palm in the USA (type locality) (Samuels \& Barr 1997).

Notes - Valetoniellopsis laxa was introduced by Samuels \& Barr (1997) from the USA. In this study, this species is sister to Trichosphaerella ceratophora (Fig. 1), but can be differentiated from $V$. laxa that has cylindrical to oblong ascospores without ascoconidia (Samuels \& Barr 1997).

\section{Other genera in Hypocreomycetidae}

Glomerellales genera incertae sedis

Ascocodinaea Samuels, Cand. \& Magni, Mycologia 89(1): 156 (1997)

Fungicolous. Sexual morph: Ascomata perithecial, solitary or scattered, superficial, globose to subglobose, black, membranaceous, tuberculate, with cylindrical, unbranched, dark brown, tapering setae, collapsing when dry, ostiolate, periphysate. Peridium composed of brown to hyaline cells of textura epidermoidea to textura prismatica. Paraphyses filiform, septate, branched. Asci 8spored, unitunicate, cylindrical, pedicellate, apex blunt, apical ring indistinct, evanescent. Ascospores uni-seriate, ellipsoidal to fusiform, straight or slightly curved, hyaline, aseptate, becoming brown median cells and hyaline end cells, usually 3 -septate, constricted at the middle 
septum, smooth-walled, guttulate. Asexual morph: Hyphomycetous. Conidiophores mononematous, macronematous, hyaline, unbranched, brown to dark brown, swollen at base. Conidiogenous cells monophialidic, enteroblastic, thicken. Conidia terminal, oval to ellipsoidal, straight or slightly curved, 0-1-septate, hyaline, smooth-walled, guttulate (adapted from Samuels et al. 1997).

Notes - Two Ascocodinaea species, A. polyporicola and A. stereicola (type), were collected from basidiomata of Polyporus sp., Stereum sp. and Trichaptum sp. in the USA (Samuels et al. 1997). This genus was initially placed in Hypocreomycetidae (Lumbsch \& Huhndorf 2007). However, Huhndorf et al. (2004a) analyzed LSU sequence data of A. stereicola and found that this species is sister to Colletotrichum gloeosporioides (= Glomerella cingulata). Subsequently, Ascocodinaea was transferred to Glomerellales genera incertae sedis (Hyde et al. 2020e, Wijayawardene et al. 2020). In this study, Ascocodinaea is basal to Plectosphaerellaceae in Glomerellales as an independent clade (Fig. 1).
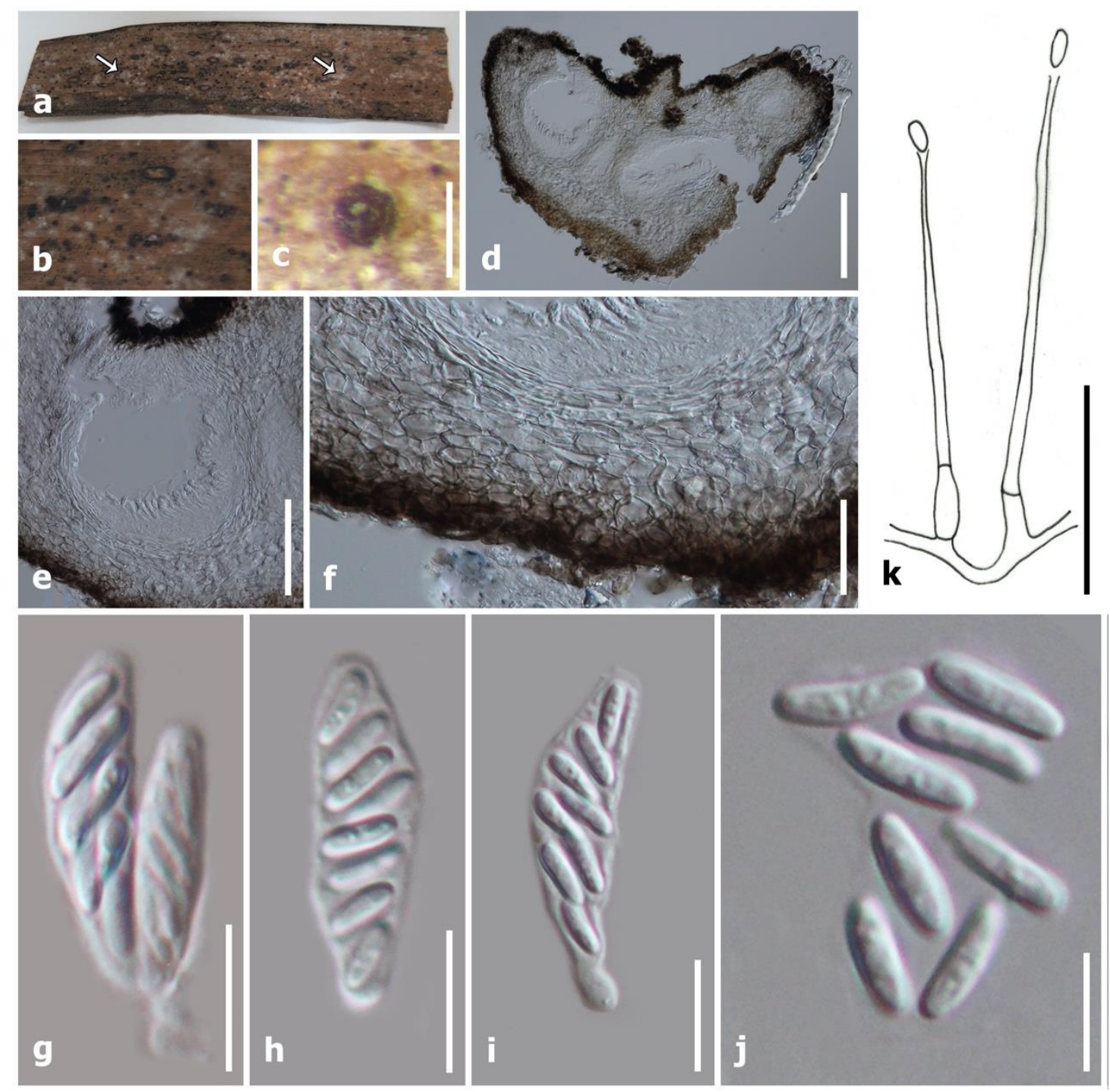

Figure 42 - Valetoniellopsis laxa: a-j (BPI-748357, holotype); k (redrawn from Samuels \& Barr 1997). a Material. b Ascomata on the host. c Ascoma. d Ascomata cross section. e A locule. f Peridium. g-i Asci. j Ascospores. k Conidiophores and conidia. Scale bars: $\mathrm{c}-\mathrm{d}=100 \mu \mathrm{m}, \mathrm{e}=50$ $\mu \mathrm{m}, \mathrm{f}, \mathrm{k}=20 \mu \mathrm{m}, \mathrm{g}-\mathrm{i}=10 \mu \mathrm{m}, \mathrm{j}=5 \mu \mathrm{m}$.

Ascocodinaea stereicola Samuels, Cand. \& Magni, Mycologia 89(1): 156 (1997)

Fig. 43

Facesoffungi number: FoF 10083 
Fungicolous. Sexual morph: Ascomata 150-180 × 120-180 $\mu \mathrm{m}(\bar{x}=160 \times 155 \mu \mathrm{m}, \mathrm{n}=10)$, perithecial, solitary or scattered, superficial, globose to subglobose, black, membranaceous, tuberculate, with cylindrical, unbranched, dark brown, tapering setae, 50-90 $\times 3-8 \mu \mathrm{m}$, collapsing when dry, ostiolate, periphysate. Peridium 15-30 $\mu \mathrm{m}$ wide, comprising two layers, outer layer composed of brown cells of textura epidermoidea; inner layer composed of hyaline cells of textura prismatica. Paraphyses 1.5-3 $\mu \mathrm{m}$ wide, filiform, septate, branched. Asci (90-)95-110(-120) $\times(5-$ 6-7(-9) $\mu \mathrm{m}(\bar{x}=100 \times 6.5 \mu \mathrm{m}, \mathrm{n}=20), 8$-spored, unitunicate, cylindrical, pedicellate, apex blunt, apical ring indistinct, evanescent. Ascospores (9-)10-13(-15) $\times(4-) 5-7(-8) \mu \mathrm{m}(\bar{x}=11 \times 5.5 \mu \mathrm{m}$, $\mathrm{n}=50$ ), uni-seriate, ellipsoidal to broadly fusiform, straight or slightly curved, hyaline, aseptate, becoming brown median cells and hyaline end cells, usually 3-septate, constricted at the middle septum, smooth-walled, guttulate. Asexual morph: Hyphomycetous. Conidiophores $2-8 \mu \mathrm{m}$ wide, mononematous, macronematous, hyaline, unbranched, brown to dark brown, swollen at base. Conidiogenous cells monophialidic, enteroblastic, thicken. Conidia (6-)7.5-9(-12) $\times(2-) 3-4(-6)$ $\mu \mathrm{m}(\bar{x}=8.5 \times 3.5 \mu \mathrm{m}, \mathrm{n}=50)$, terminal and lateral, oval to ellipsoidal, straight or slightly curved, 0-1-septate, hyaline, smooth-walled, guttulate (adapted from Samuels et al. 1997).

Material examined - USA, Kentucky. Laurel Co., Daniel Boone National Forest, Laurel River Lake Recreation Area, Cane Creek Wildlife Refuge, alt. 350 m, on Stereum sp., 27 September 1995, G.J. Samuels (BPI-749458, holotype); ibid. (BPI-749459, isotype).

Known hosts and distribution - on Stereum in the USA (type locality) (Samuels et al. 1997).

Notes - The fungicolous Ascocodinaea stereicola usually found on Stereum (Samuels et al. 1997). It is closely related to members of Glomerellales based on LSU sequence data (Huhndorf et al. 2004b, Hyde et al. 2020e, this study, Fig. 1).

Torpedosporales E.B.G. Jones, Abdel-Wahab \& K.L. Pang

Etheirophoraceae Rungjind., Somrith. \& Suetrong

Etheirophora Kohlm. \& Volkm.-Kohlm., Mycol. Res. 92(4): 414 (1989)

Saprobic on wood in marine habitats. Sexual morph: Ascomata perithecial, solitary, immersed, pyriform, pale brown, coriaceous, papillate. Papilla conical, brown, ostiolate, periphysate, sometimes erumpent through the wood surface and surrounded by irregular, brown clypeus. Peridium composed of pale brown cells of textura angularis. Paraphyses filiform, septate, branched. Asci 8-spored, unitunicate, cylindrical to clavate, pedicellate, apex rounded or blunt, apical ring absent, evanescent. Ascospores bi-seriate, hyaline, ellipsoidal, straight or slightly curved, 1-septate, smooth-walled, with 5-8 filiform appendages at one or each end, guttulate. Asexual morph: Undetermined (adapted from Kohlmeyer \& Volkmann-Kohlmeyer 1989).

Notes - Kohlmeyer \& Volkmann-Kohlmeyer (1989) found Etheirophora bijubata (type), E. blepharospora and E. unijubata on rotten wood collected in Hawaii. They have ellipsoidal ascospores with several filiform terminal appendages at one or each end (Kohlmeyer \& VolkmannKohlmeyer 1989). However, Schoch et al. (2007) sequenced E. blepharospora and E. unijubata. Subsequently, Jones et al. (2014) established Etheirophoraceae, which accommodated Etheirophora and Swampomyces. Etheirophora and Swampomyces that form a clade as Etheirophoraceae (Jones et al. 2014, this study, 100\%ML/1.00BY, Fig. 1). Swampomyces is different from Etheirophora in that its ellipsoidal ascospores lacks appendages (Jones et al. 2014).

Etheirophora bijubata Kohlm. \& Volkm.-Kohlm., Mycol. Res. 92(4): 414 (1989)

Fig. 44a-n

Facesoffungi number: FoF 10084

Saprobic on wood in marine habitats. Sexual morph: Ascomata 140-260 $\times 270-475 \mu \mathrm{m}(\bar{x}=$ $200 \times 340 \mu \mathrm{m}, \mathrm{n}=10$ ), perithecial, solitary, immersed, pyriform, pale brown, coriaceous, papillate. Papilla conical, brown, ostiolate, periphysate, sometimes erumpent through the wood surface and surrounded by irregular, brown clypeus. Peridium 5-18 $\mu \mathrm{m}$ wide, comprising two layers, outer layer composed of brown to pale brown cells of textura angularis; inner layer composed of hyaline cells of textura prismatica. Paraphyses 0.6-1.6 $\mu \mathrm{m}$ wide, filiform, septate, branched. Asci (60-)65$75(-90) \times(9-) 10-12(-15) \mu \mathrm{m}(\bar{x}=74 \times 11.5 \mu \mathrm{m}, \mathrm{n}=20), 8$-spored, unitunicate, cylindrical to 
clavate, pedicellate, apex rounded or blunt, apical ring absent, evanescent. Ascospores (14-)16$18(-21) \times(5-) 5.5-7(-8) \mu \mathrm{m}(\bar{x}=17 \times 6 \mu \mathrm{m}, \mathrm{n}=50)$, bi-seriate, hyaline, ellipsoidal, straight or slightly curved, 1-septate, smooth-walled, with 5-8 filiform, appendages at each end, guttulate. Asexual morph: Undetermined (adapted from Kohlmeyer \& Volkmann-Kohlmeyer 1989).

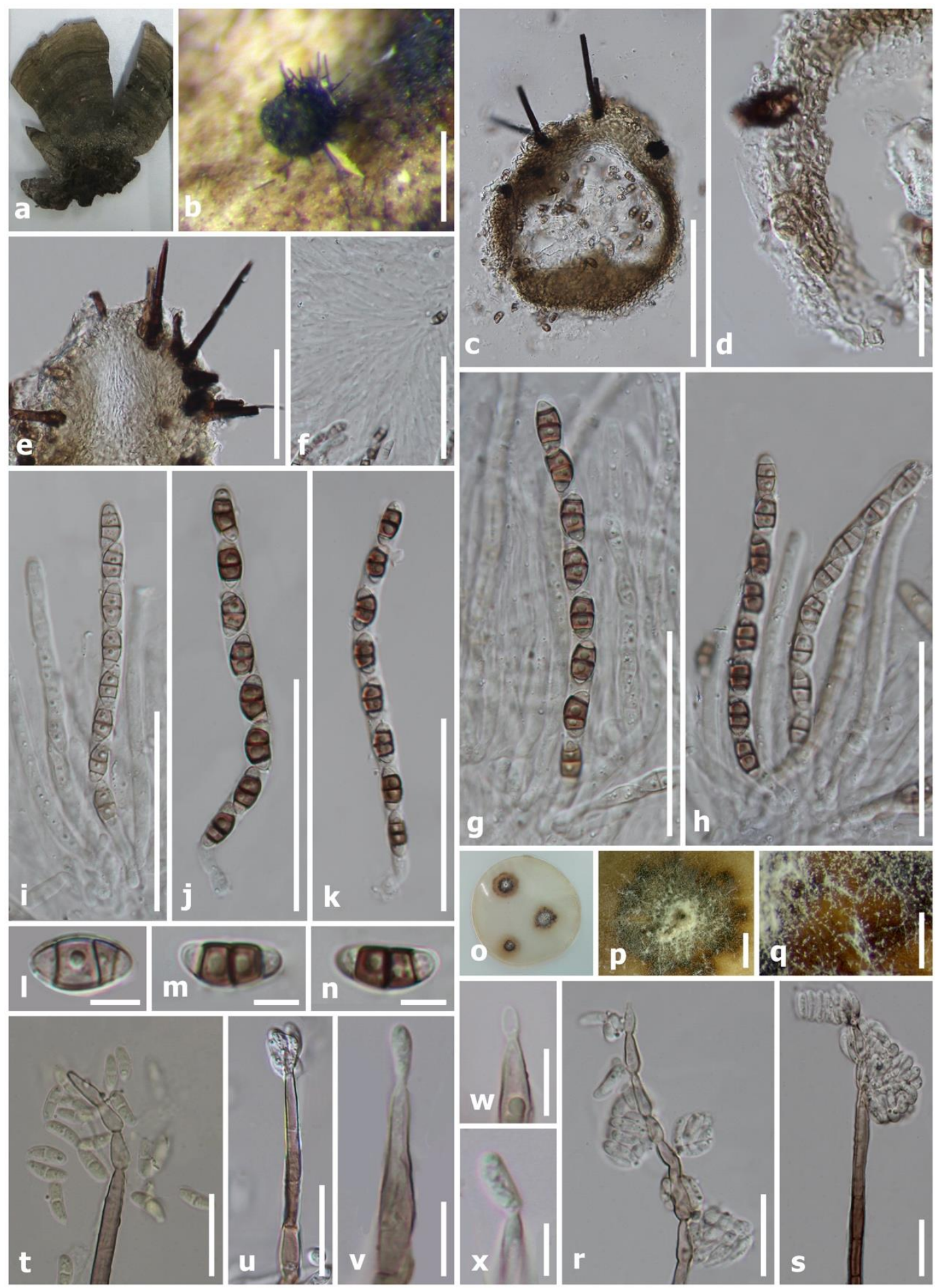

Figure 43 - Ascocodinaea stereicola: b-n (BPI-749458, holotype); a, o-x (BPI-749459, isotype). a Material (Stereum sp.). b Ascoma on host. c Ascoma cross section. d Peridium. e Ostiole surrounded by setae. f Paraphyses. g-k Asci. 1-n Ascospores. o-q Colonies on dry culture on surface view. $r-x$ Conidiophores and conidia. Scale bars: $\mathrm{p}=2 \mathrm{~mm}, \mathrm{q}=500 \mu \mathrm{m}, \mathrm{b}=200 \mu \mathrm{m}, \mathrm{c}=$ $100 \mu \mathrm{m}, \mathrm{e}-\mathrm{k}=50 \mu \mathrm{m}, \mathrm{d}, \mathrm{r}-\mathrm{u}=20 \mu \mathrm{m}, \mathrm{v}-\mathrm{w}=10 \mu \mathrm{m}, \mathrm{l}-\mathrm{n}, \mathrm{x}=5 \mu \mathrm{m}$. 

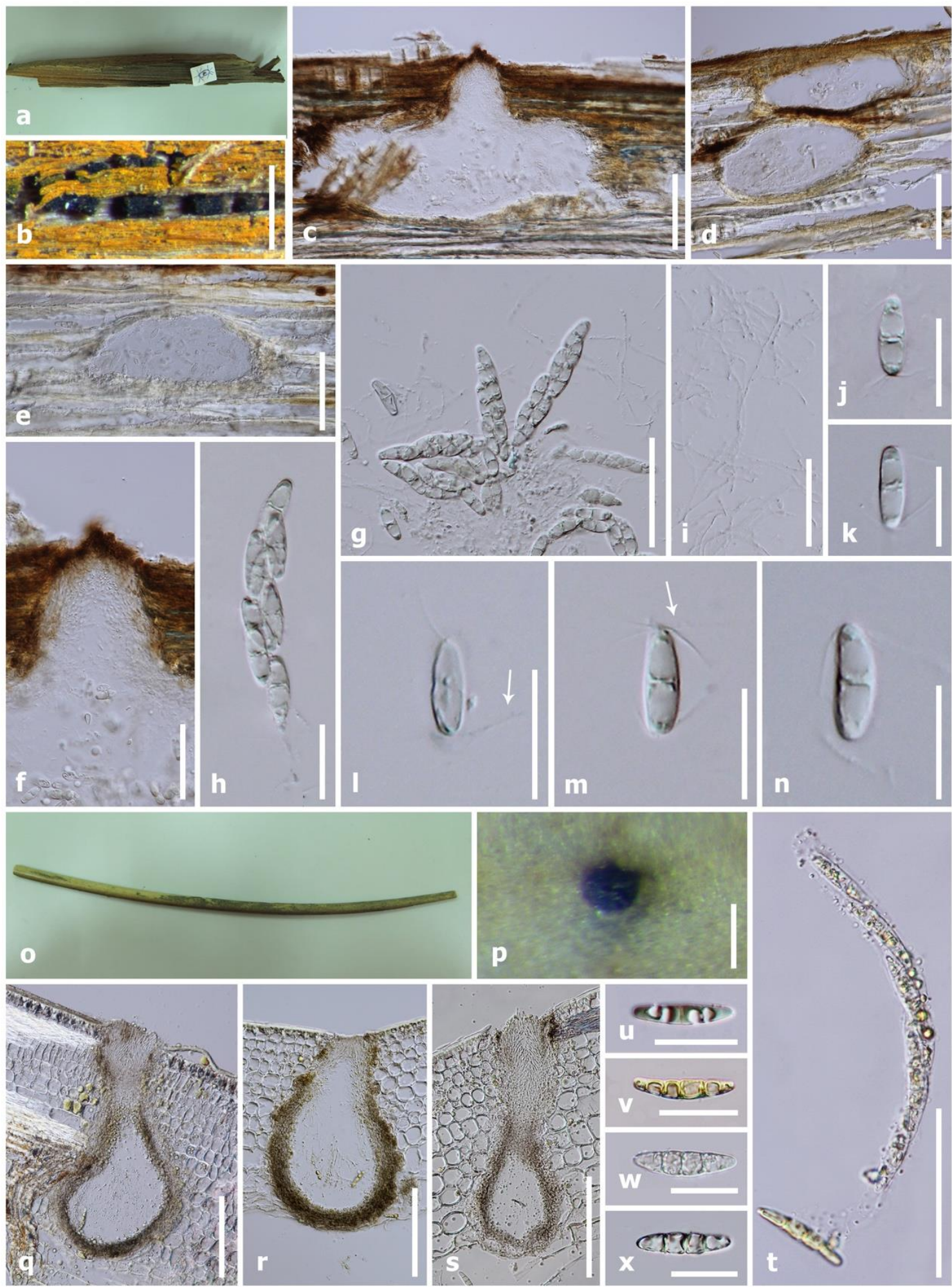

Figure 44 - Etheirophora bijubata: a-n (NY-1315470, microslide of holotype). a Material. b Immersed ascomata. c-e Ascomata cross section. f Ostiole with periphyses. g-h Asci. i Paraphyses. j-n Ascospores; Juncigena adarca: o-x (NY-1276214, holotype). o Material. $\mathrm{p}$ Immersed ascoma on surface view. q-s Ascomata cross section. $t$ Evanescent ascus. $\mathrm{u}-\mathrm{x}$ Ascospores. Notes: $\mathrm{t}, \mathrm{v}-\mathrm{x}$ stained in Melzer's reagent. Scale bars: $\mathrm{b}=500 \mu \mathrm{m}, \mathrm{c}-\mathrm{e}, \mathrm{p}-\mathrm{s}=100$ $\mu \mathrm{m}, \mathrm{f}-\mathrm{g}, \mathrm{i}, \mathrm{t}=50 \mu \mathrm{m}, \mathrm{h}, \mathrm{j}-\mathrm{n}, \mathrm{u}-\mathrm{x}=20 \mu \mathrm{m}$.

Material examined - USA, Hawaii. Haena Beach, Hanalei, Kauai (Pacific Ocean), $22^{\circ} 13^{\prime} 18^{\prime \prime} \mathrm{N}, 159^{\circ} 34^{\prime} 16^{\prime \prime} \mathrm{W}(22.222,-159.571)$, on intertidal wood which embedded in concrete 
(incubated in a moist chamber for 9 months), 8 March 1987, J.J. Kohlmeyer, B. VolkmannKohlmeyer (NY-1315470, microslide of holotype).

Known hosts and distribution - on intertidal wood in the USA (type locality) (Kohlmeyer \& Volkmann-Kohlmeyer 1989).

Notes - The marine fungus Etheirophora bijubata was introduced as type (Kohlmeyer \& Volkmann-Kohlmeyer 1989), but no sequence data is available.

Swampomyces Kohlm. \& Volkm.-Kohlm., Bot. Mar. 30(3): 198 (1987)

Saprobic on wood in marine habitats. Sexual morph: Ascomata perithecial, solitary, immersed, pyriform, pale brown, with black papilla on surface view, coriaceous, ostiolate, periphysate. Peridium composed of pale brown to hyaline cells of textura epidermoidea to textura angularis to textura prismatica. Pseudoparaphyses filiform, septate, branched, attached at the top and bottom. Asci 8-spored, unitunicate, cylindrical, pedicellate, apex rounded or blunt, apical ring absent, evanescent. Ascospores uni-seriate, hyaline, ellipsoidal, hyaline to yellowish, septate, verrucose, guttulate. Asexual morph: Undetermined (adapted from Kohlmeyer \& VolkmannKohlmeyer 1987).

Notes - Swamponyces was established for S. armeniacus which was collected on mangrove wood in Belize (Kohlmeyer \& Volkmann-Kohlmeyer 1987). Subsequently, S. aegyptiacus, S. clavatisporus and $S$. triseptatus were introduced from mangrove substrates with immersed ascomata and ellipsoidal, septate ascospores (Hyde \& Nakagiri 1992, Abdel-Wahab et al. 2001). These species were sequenced by Sakayaroj et al. (2005) and Schoch et al. (2007). Thus, phylogenetically, Swampomyces aegyptiacus and S. clavatisporus were clarified as Fulvocentrum species in Juncigenaceae; while, Etheirophora and Swampomyces clustered in Etheirophoraceae (Jones et al. 2014, this study, Fig. 1).

Swampomyces armeniacus Kohlm. \& Volkm.-Kohlm., Bot. Mar. 30(3): 200 (1987)

Fig. 45

Facesoffungi number: FoF 05390

Saprobic on wood in marine habitats. Sexual morph: Ascomata 300-400 $\times 350-600 \mu \mathrm{m}(\bar{x}=$ $345 \times 480 \mu \mathrm{m}, \mathrm{n}=10$ ), perithecial, solitary, immersed, pyriform, pale brown, with black papilla on surface view, coriaceous, ostiolate, periphysate. Peridium 24-35 $\mu \mathrm{m}$ wide, carbonaceous, black tissues at apex, fused with cells of substrate, venter wall comprising two layers, membranaceous, outer layer composed of pale brown to hyaline cells of textura epidermoidea to textura angularis; inner layer composed of hyaline cells of textura prismatica. Pseudoparaphyses $1.2-2.5 \mu \mathrm{m}$ wide, filiform, septate, branched, attached at the top and bottom. Asci $(100-) 125-140(-160) \times(15-) 17-$ 18(-20) $\mu \mathrm{m}(\bar{x}=135 \times 17.5 \mu \mathrm{m}, \mathrm{n}=20), 8$-spored, unitunicate, cylindrical, pedicellate, apex rounded or blunt, apical ring absent, evanescent. Ascospores $(11-) 14-18(-22) \times(6.5-) 7.5-9(-10)$ $\mu \mathrm{m}(\bar{x}=16.5 \times 8 \mu \mathrm{m}, \mathrm{n}=50)$, uni-seriate, hyaline, ellipsoidal, hyaline to yellowish, 1-septate, verrucose, guttulate. Asexual morph: Undetermined (adapted from Kohlmeyer \& VolkmannKohlmeyer 1987).

Material examined - Belize, Man-Of-War Cay (Atlantic Ocean). 16 $6^{\circ} 53^{\prime} 00^{\prime \prime} \mathrm{N}, 88^{\circ} 06^{\prime} 15^{\prime \prime} \mathrm{W}$ (16.883, -88.104), on driftwood, 23 November 1984, J.J. Kohlmeyer (NY-1271822, paratype).

Known hosts and distribution - on decayed wood of Rhizophora in Australia and Belize (type locality) (Kohlmeyer \& Volkmann-Kohlmeyer 1987, Read et al. 1995).

Notes - Swampomyces armeniacus was introduced by Kohlmeyer \& Volkmann-Kohlmeyer (1987) from Belize. It is sister to S. triseptatus in Etheirophoraceae (Sakayaroj et al. 2005, Schoch et al. 2007, Jones et al. 2014, this study, 96\%ML/1.00BY, Fig. 1), differing from it in the possessing of 1-septate ascospores, whereas the latter that has 3-septate ascospores.

Juncigenaceae E.B.G. Jones, Abdel-Wahab \& K.L. Pang

Juncigena Kohlm., Volkm.-Kohlm. \& O.E. Erikss., Bot. Mar. 40(4): 291 (1997)

Saprobic on leaves or culms in marine habitats. Sexual morph: Ascomata perithecial, solitary, immersed, pyriform to subglobose, brown, coriaceous, ostiolate, periphysate. Peridium composed 
of membranaceous, pale brown to hyaline cells of textura angularis to textura prismatica. Pseudoparaphyses filiform, septate, unbranched, attached at the top and bottom. Asci 8-spored, unitunicate, cylindrical, pedicellate, apex blunt, apical ring, blue in methylene blue, evanescent. Ascospores uni- to bi-seriate, ellipsoidal to fusiform, straight or slightly curved, hyaline, 3-septate, constricted at the septa, smooth-walled, guttulate. Asexual morph: Hyphomycetous. Hyphae hyaline to pale brown, septate, branched. Conidia developing directly on hyphae or on nonspecialized short lateral conidiogenous cells, solitary, irregularly helicoid, pale brown to dark brown, 4-9-septate, smooth-walled, guttulate (adapted from Kohlmeyer et al. 1997).

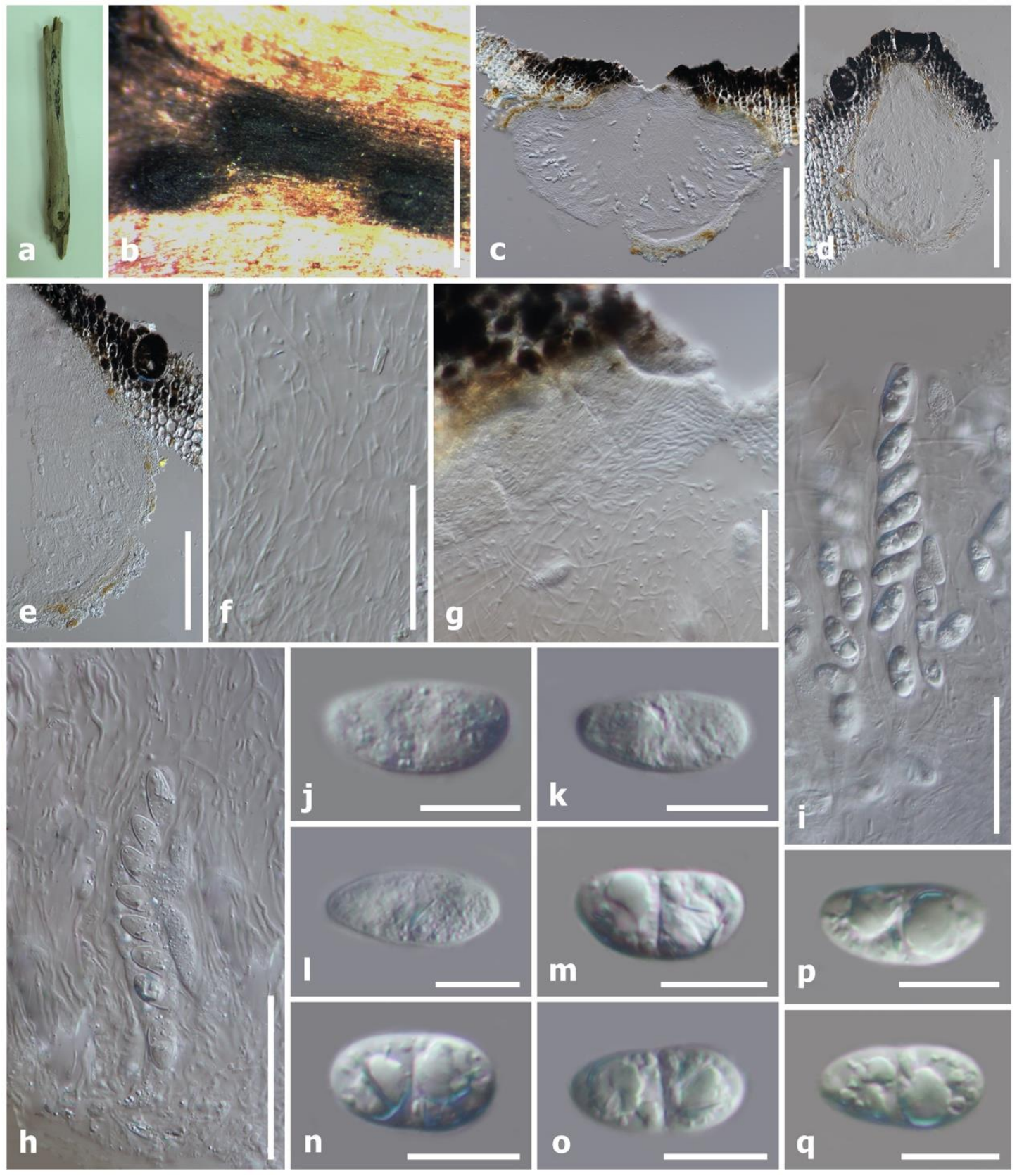

Figure 45 - Swampomyces armeniacus: (NY-1271822, paratype). a Material. b Ascomata on the host. c-d Ascomata cross section. e Peridium. f Pseudoparaphyses. g Ostiole with periphyses. $\mathrm{h}-\mathrm{i}$ Asci. j-q Ascospores. Scale bars: $\mathrm{b}=1 \mathrm{~mm}, \mathrm{c}-\mathrm{d}=200 \mu \mathrm{m}, \mathrm{e}=100 \mu \mathrm{m}, \mathrm{f}-\mathrm{i}=50 \mu \mathrm{m}, \mathrm{j}-\mathrm{q}=10$ $\mu \mathrm{m}$.

Notes - Juncigena was introduced as a monotypic genus for J. adarca in Magnaporthaceae (Kohlmeyer et al. 1997). Schoch et al. (2007) sequenced the type and placed this genus in 
Juncigenaceae (Jones et al. 2014). Later, the second species $J$. fruticosae was introduced from the hyphomycetous Moheitospora fruticosae based on sequence data (Abdel-Wahab et al. 2010). In this study, Juncigena is sister to Khaleijomyces and Marinokkulati (75\%ML/0.91BY, Fig. 1).

Juncigena adarca Kohlm., Volkm.-Kohlm. \& O.E. Erikss., Bot. Mar. 40(4): 291 (1997)

Facesoffungi number: FoF 10085

Fig. $440-x$

Saprobic on leaves or culms in marine habitats. Sexual morph: Ascomata 220-300 × 150-180 $\mu \mathrm{m}(\bar{x}=270 \times 160 \mu \mathrm{m}, \mathrm{n}=5)$, perithecial, solitary, immersed, pyriform to subglobose, brown, coriaceous, ostiolate, periphysate. Peridium 7-35 $\mu \mathrm{m}$ wide, comprising two layers, outer layer composed of pale brown cells of textura angularis; inner layer composed of hyaline cells of textura prismatica. Pseudoparaphyses filiform, septate, unbranched, attached at the top and bottom. Asci 8spored, unitunicate, cylindrical, pedicellate, apex blunt, apical ring, blue in methylene blue, evanescent. Ascospores (23-)26-30(-32) $\times(5-) 6-7 \mu \mathrm{m}(\bar{x}=27 \times 56 \mu \mathrm{m}, \mathrm{n}=10)$, uni- to bi-seriate, ellipsoidal to fusiform, straight or slightly curved, hyaline, 3-septate, constricted at the septa, smooth-walled, guttulate. Asexual morph: Hyphomycetous. Hyphae hyaline to pale brown, septate, branched. Conidia developing directly on hyphae or on non-specialized short lateral conidiogenous cells, solitary, irregularly helicoid, pale brown to dark brown, 4-9-septate, smooth-walled, guttulate (adapted from Kohlmeyer et al. 1997).

Material examined - USA, North Carolina, Broad Creek (Atlantic Ocean), 34 $43^{\prime} 00^{\prime \prime} \mathrm{N}$, $76^{\circ} 55^{\prime} 07^{\prime \prime} \mathrm{W}$ (34.717, -76.919), on dead culms of Juncus roemerianus, 9 October 1994, J.J. Kohlmeyer (NY-1276214, holotype).

Known hosts and distribution - on dead leaves and culms of Juncus roemerianus (Juncaceae) in the USA (type locality) (Kohlmeyer et al. 1997).

Notes - Juncigena adarca was collected on leaves of Juncus at atlantic coast in the USA and its asexual morph produced on seawater agar medium (Kohlmeyer et al. 1997). Later, it was placed in Juncigenaceae based on phylogenetic results (Schoch et al. 2007, Jones et al. 2014). In this study, J. adarca is sister to hyphomycetous $J$. fruticosae (Abdel-Wahab et al. 2010, this study, 93\%ML/0.98BY, Fig. 1).

Sordariomycetes genera incertae sedis

Cryptosphaerella Sacc., Syll. fung. (Abellini) 1: 186 (1882)

Saprobic on wood. Sexual morph: Ascomata perithecial, scattered to gregarious, immersed to erumpent, coriaceous to membranaceous, brown to black, globose to subglobose, ostiolate, periphysate. Peridium composed of membranaceous, brown to hyaline cells of textura angularis to textura prismatica. Paraphyses absent. Asci polysporous, unitunicate, cylindrical, pedicellate, apex rounded, without apical ring, evanescent. Ascospores overlapping, hyaline, allantoid to cylindrical, aseptate, usually slightly curved, smooth-walled, guttulate. Asexual morph: Undetermined (adapted from Saccardo 1882b, Spegazzini 1909, 1922, 1926).

Notes - Cryptosphaerella was introduced similar to Cryptosphaeria (Diatrypaceae) in having ostiolate ascomata and allantoid, aseptate ascospores (Saccardo 1882a). Later, because of the polysporous asci, it was considered similar to Coronophora (von Höhnel 1907), but sequence data is not available for the type $C$. nitschkei. Mugambi \& Huhndorf (2010) sequenced six 'Cryptosphaerella' species, C. celata, C. costaricensis, C. cylindriformis, C. elliptica, C. globosa and $C$. malindensis, which have ascomata lacking ostioles and with Quellkörper. Thus, Cryptosphaerella was transferred to Scortechiniaceae based on the phylogenetic analysis of these six species. Mugambi \& Huhndorf (2010) believed that Quellkörper is a key feature of Scortechiniaceae, while the type of Cryptosphaerella does not have this character (Fig. 25i). Therefore, these six species are related to Scortechiniaceae, but do not belong to Cryptosphaerella. We have reassigned them based on morphology and phylogenetic result (see notes for Neocryptosphaerella and Pseudocryptosphaerella). Here, we transfer Cryptosphaerella to Sordariomycetes genera incertae sedis pending future work. 
Cryptosphaerella nitschkei (Auersw.) Sacc., Syll. fung. (Abellini) 1: 186 (1882)

Fig. $25 \mathrm{~g}-\mathrm{k}$

Basionym - Valsa nitschkei Auersw., in Nitschke, Pyrenomyc. Germ. 2: 163 (1870)

Facesoffungi number: FoF 10182

Saprobic on wood. Sexual morph: Ascomata perithecial, densely gregarious, immersed to erumpent, coriaceous to membranaceous, brown to black, globose to subglobose, with periphyses inside of the ostioles. Peridium composed of membranaceous, brown cells of textura angularis. Paraphyses absent. Asci polysporous, unitunicate, cylindrical, pedicellate, apex rounded, without apical ring, evanescent. Ascospores overlapping, hyaline, allantoid, aseptate, slightly curved, smooth-walled, guttulate. Asexual morph: Undetermined (adapted from Saccardo 1882b).

Material examined - GERMANY, Oederan, on rotten wood, September 1871, H.G. Winter (IMI-K-M251354); ibid. (NY-02934200).

Known hosts and distribution - on decayed wood of Salix in Germany (type locality) (Saccardo 1882a).

Notes - The type material is unable to obtain. We re-examined two authentic specimens collected by Winter from Germany, but fruiting bodies are empty.

\section{Discussion}

Taxonomy is the science of classification, including naming, describing, classifying plants, animals and microorganisms (https://www.cbd.int/gti/taxonomy.shtml, Kirk et al. 2008, Enghoff 2009). Initially, fungi were described and classified based on shared morphological characteristics (Nannfeldt 1932, Lundqvist 1972). Many species collected and examined earlier have been described only based on morphological data, and some have drawings. This information is not enough to allow these species to be easily identified in the current research arena. For example, Cryptosphaerella, was believe to possess Quellkörper (Mugambi \& Huhndorf 2010) but in this study, we observed that the type species of Cryptosphaerella (C. nitschkei) has ostiolate ascomata instead of Quellkörper. Mugambi \& Huhndorf (2010) redefined the families in Coronophorales based on morphology and LSU, TEF and RPB2 genes analyses. They proposed that usually, Bertiaceae has robust ascomata with warted or tuberculate walls; Scortechiniaceae has quellkörper structure in ascomata (Mugambi \& Huhndorf 2010), which is similar to what we have observed in this study. However, based on the review of the type species, we found that it is difficult to distinguish other Coronophorales families by the number of ascospores per ascus, ascospore appendages or ascomatal vestiture. We recommend determining the taxonomic placement of each family by multi-gene analyses. Podospora anserina has been used as a model filamentous organism for more than 100 years and it is widely used in various research in biological science (Scheckhuber \& Osiewacz 2008, Ament-Velásquez et al. 2020), but its taxonomy has been controversial. Wang et al. (2019a) combined P. anserina under Triangularia anserina based on its type strain, CBS 433.50, which was phylogenetically related to Triangularia. Ament-Velásquez et al. (2020) believes that the widely used name $P$. anserina should be retained to avoid confusion in research. In the past two decades, many novel taxa in Ascomycota have been discovered based on morphological examination coupled with sequence data (Cai et al. 2005, Wang et al. 2019a, MarinFelix et al. 2020, Hyde et al. 2020e). Therefore, it is necessary to supplement the descriptions, photoplates and molecular information of the species that have been discovered. This will improve the classification system of fungi and allow us to find some overlooked species or characteristics, like in Synaptospora. Huhndorf et al. (1999) and Réblová (2002) noted that the ascospores of Synaptospora fuse into several groups in the ascus when mature; however, Huang et al. (2021) reexamined the type $S$. petrakii and found that the ascospores began to produce septa when immature and split into individual spore cells when mature.

We provide descriptions, photoplates or drawings by reviewing type/authentic material together with the literature in Coronophorales and Niessliaceae. In this study, several type materials are not reviewed. This is because 1) the sample information is missing, including the herbarium details; 2) the samples were lost, destroyed or contaminated; 3) the samples are fragile and/or cannot be transported and 4) the species has been published recently, with detailed photoplates and 
descriptions. We also found that some morphological characters of some species were hard to or could not be observed when re-examined, especially for older type material. For example, Patouillard (1922) noted that Spinulosphaeria thaxteri has hyaline and evanescent paraphyses, but we did not observe paraphyses in the holotype material of $S$. thaxteri collected in 1898. Engler (1895) recorded that Euacanthe usambarensis has elongated fusiform asci with a long pedicel about $21 \mu \mathrm{m}$. We reviewed its holotype material from 1893 and found that most of the pedicels of the asci could not be observed; thus, we could not provide a measurement for the pedicel.

Some studies have published DNA based information on known species, e.g Cai et al. (2006) and $\mathrm{Vu}$ et al. (2019). These data provided better insights into the taxonomic placement of some controversial taxa. For example, the polyphyletic Lasiosphaeriaceae with cylindrical to pod-like ascospores is divided into six families based on phylogenetic results ( $\mathrm{Vu}$ et al. 2019, Wang et al. 2019a, Marin-Felix et al. 2020, Huang et al. 2021). However, we have not been able to sequence the reviewed materials in this study. We expect that the sequence data of all species can eventually be published. This allows us to determine the classification of taxa more accurately, and makes the taxa easier to be identified and used in other researches. Likewise, it is necessary to recollect and identify species based on type material collection information, morphology and molecular data. These will be meaningful for various biological research, such as evolution, ecology and chemistry.

\section{Acknowledgements}

This work was jointly supported by the National Natural Science Foundation of China (No. 31760014) and the Science and Technology Foundation of Guizhou Province (No. [2019]2451-3). Shi-Ke Huang thanks to Ming Zeng, Drs. S. Boonmee, P. Chomnunti, A.H. Ekanayaka, R. Jeewon, Ji-Chuan Kang, Xiang-Yu Zeng and Qi Zhao for their invaluable suggestions and help in this study. Kevin D. Hyde acknowledges the future of specialist fungi in a changing climate: baseline data for generalist and specialist fungi associated with ants, Rhododendron species and Dracaena species (grant no: DBG6080013) and Impact of climate change on fungal diversity and biogeography in the Greater Mekong Subregion (grant no: RDG6130001). Shaun Pennycook is thanked for checking and correcting the Latin names.

\section{References}

Abdel-Wahab MA, El-Sharouney H, Jones EBG. 2001 - Two new intertidal lignicolous Swampomyces species from Red Sea Mangroves in Egypt. Fungal Diversity 8, 35-40.

Abdel-Wahab MA, Pang KL, Nagahama T, Abdel-Aziz FA, Jones EBG. 2010 - Phylogenetic evaluation of anamorphic species of Cirrenalia and Cumulospora with the description of eight new genera and four new species. Mycological Progress 9(4), 537-558.

Ament-Velásquez SL, Johannesson H, Giraud T, Debuchy R et al. 2020 - The taxonomy of the model filamentous fungus Podospora anserina. MycoKeys 75, 51-69.

Ashrafi S, Stadler M, Dababat AA, Richert-Pöggeler KR et al. 2017 -Monocillium gamsii sp. nov. and i: two nematode-associated fungi parasitising the eggs of Heterodera filipjevi. MycoKeys $27,21-38$.

Auerswald B. 1869 - Synopsis pyrenomycetum europaeorum. In: Gonnerman W, Rabenhorst GL (eds). Mycologia Europaea 5-6, 1-30.

Barr ME. 1983 - The ascomycete connection. Mycologia 75(1), 1-13.

Barr ME. 1985 - Notes on the Calosphaeriales. Mycologia 77(4), 549-565.

Barr ME. 1990 - Prodromus to nonlichenized, pyrenomycetous members of class Hymenomycetes. Mycotaxon 39, 43-184.

Batista AC, Bezerra JL, Castrillon AL, da Matta EAF. 1964 - Novos Ascomycetos foliícolas e caulinares. Publicações do Instituto de Micologia da Universidade do Recife 431, 1-22.

Berkeley MJ, Broome CE. 1873 - Enumeration of the fungi of Ceylon. Part II. Journal of the Linnean Society Botany 14, 29-141.

Berkeley MJ. 1875 - Notices of North American fungi. Grevillea 4(30), 45-52. 
Berkeley MJ. 1876 - Notices of North American fungi. Grevillea 4(32), 141-162.

Bommer E, Rousseau M. 1890 - Contributions à la Flore Mycologique de Belgique. IV. Bulletin de la Société Royale de Botanique de Belgique 29(1), 205-302.

Booth C. 1958 - The genera Chaetosphaeria and Thaxteria in Britain. Naturalist, 83-90.

Bory de Saint-Vincent JBGM, Durieu de Maisonneuve MC. 1849 - Exploration scientifique de l'Algérie. 1 13, 481-520.

Boudier E. 1904 - Sur un nouveau genre et une nouvelle espèce de Myriangiacées, le Guilliermondia saccoboloides. Bulletin de la Société Mycologique de France 20, 19-22.

Bundhun D, Maharachchikumbura SSN, Jeewon R, Senanayake IC et al. 2020 https://sordariomycetes. org/, a platform for the identification, ranking. Asian Journal of Mycology 3(1), 13-21.

Cai L, Jeewon R, Hyde KD. 2005 - Phylogenetic evaluation and taxonomic revision of Schizothecium based on ribosomal DNA and protein coding genes. Fungal Diversity 19, 121.

Cai L, Jeewon R, Hyde KD. 2006 - Phylogenetic investigations of Sordariaceae based on multiple gene sequences and morphology. Mycological research 110(2), 137-150.

Calabon MS, Hyde KD, Jones EBG, Chandrasiri S et al. 2020 - www.freshwaterfungi.org, an online platform for the taxonomic classification of freshwater fungi. Asian Journal of Mycology 3(1), 419-445.

Cannon PF, Hawksworth DL. 1983 - Arxiomyces, a new name for Phaeostoma von Arx \& E. Müller. Transactions of the British Mycological Society 81(3), 644-645.

Cannon PF. 1982 - Pustulipora, a new genus of the Melanosporaceae. Mycotaxon 15, 523-528.

Cannon PF, Hawksworth DL. 1982 - A re-evaluation of Melanospora Corda and similar Pyrenomycetes, with a revision of the British species. Botanical Journal of the Linnean Society 84(2), 115-160.

Carneiro de Almeida DA, Pascholati Gusmão LF, Miller AN. 2016 - Brazilian Semi-Arid Ascomycetes II: New and interesting records of Bertiaceae, Nitschkiaceae and Scortechiniaceae (Coronophorales, Sordariomycetes). Nova Hedwigia 102(3-4), 513-522.

Chaudhary P, Campbell J, Hawksworth DL, Sastry KN. 2006 - Vittatispora, a new melanosporaceous genus from Indian soil. Mycologia 98(3), 460-467.

Corda ACJ. 1837 - Icones fungorum hucusque cognitorum. Prague 1, 1-31.

Corda ACJ. 1838 - Icones fungorum hucusque cognitorum. Prague 2, 1-43.

Corda ACJ. 1839 - Pracht - Flora. Europaeischer Schimmel-Bildungen. G. Fleischer.

Corda ACJ. 1842 - Icones fungorum hucusque cognitorum. Prague 5, 1-92.

Costantin J. 1888 - Les mucédinées simples. Histoire, classification, culture et rôle des champignons inférieurs dans les maladies des végétaux et des animaux. Paris: P. Klincksieck.

Courtecuisse R, Samuels GJ, Hoff M, Rossman AY et al. 1996 - Check-list of Fungi from French Guiana. Mycotaxon 57, 1-85.

Crous PW, Mohammed C, Glen M, Verkley GJM, Groenewald JZ. 2007 - Eucalyptus microfungi known from culture. 3. Eucasphaeria and Sympoventuria genera nova, and new species of Furcaspora, Harknessia, Heteroconium and Phacidiella. Fungal Diversity 25, 19-36.

Crous PW, Wingfield MJ, Guarro J, Cheewangkoon R et al. 2013 - Fungal Planet description sheets: 154-213. Persoonia 31, 188-296.

Crous PW, Wingfield MJ, Burgess TI, Hardy GEStJ et al. 2016 - Fungal Planet description sheets: 469-557. Persoonia 37, 218-403.

Crous PW, Wingfield MJ, Burgess TI, Hardy GEStJ et al. 2017 - Fungal Planet description sheets: 558-624. Persoonia 38, 240-384.

Crous PW, Luangsa-ard JJ, Wingfield MJ, Carnegie AJ et al. 2018 - Fungal Planet description sheets: 785-867. Persoonia 41, 238-417.

Crous PW, Carnegie AJ, Wingfield MJ, Sharma R et al. 2019a - Fungal Planet description sheets: 868-950. Persoonia: Molecular Phylogeny and Evolution of Fungi 42(291-473), 
Crous PW, Wingfield MJ, Lombard L, Roets F et al. 2019b - Fungal Planet description sheets: 951-1041. Persoonia 43, 223-425.

Crous PW, Cowan DA, Maggs-Kölling G, Yilmaz N et al. 2020a - Fungal Planet description sheets: 1112-1181. Persoonia 45, 251-409.

Crous PW, Wingfield MJ, Schumacher RK, Akulov A et al. 2020b - New and interesting fungi. 3. Fungal Systematics and Evolution 6, 157-231.

Dayarathne MC, Boonmee S, Braun U, Crous PW et al. 2016 - Taxonomic utility of old names in current fungal classification and nomenclature: Conflicts, confusion \& clarifications. Mycosphere 7(11), 1622-1648.

De Notaris G. 1844 - Cenni sulla tribù dei Pirenomiceti sferiacei e descrizione di alcuni generi spettanti alla medesima. Giornale Botanico Italiano 1, 322-355.

Dulymamode R, Cannon PF, Sivanesan A, Peerally A. 2001 - Fungi from Mauritius: four new ascomycetes on native plants. Mycological Research 105(2), 247-254.

Ellis JB, Everhart BM. 1892 - Norht American Pyrenomycetes. Newfield, 793.

Enghoff H. 2009 - What is taxonomy?-An overview with myriapodological examples. Soil organisms 81(3), 441-451.

Engler A. 1895 - Die Pflanzenwelt Ost-Afrikas und der Nachbargebiete. Teil C, 1-433.

Eriksson OE, Hawksworth DL. 1987 - Outline of the Ascomycetes. Syst Ascomycetum 6, 259337.

Eriksson OE. 1992 - The nonlichenized pyrenomycetes of Sweden. Lund, 208.

Eriksson OE, Hawksworth DL. 1993 - Outline of the Ascomycetes-1993. Systema Ascomycetum $12,51-257$.

Eriksson OE, Winka K. 1997 - Supraordinal taxa of Ascomycota. Myconet 1(1), 1-16.

Etayo J. 2002 - Aportación al conocimiento de los hongos liquenícolas de Colombia. Bibliotheca Lichenologica 84, 1-154.

Etayo J, Sancho LG. 2008 - Hongos liquenícolas del sur de Sudamérica, especialmente de Isla Navarino (Chile). Bibliotheca Lichenologica 98, 1-302.

Etayo J. 2017 - Hongos liquenícolas de Ecuador. Opera Lilloana 50, 1-535.

Fan L, Hou CL, Cannon PF, Li Y. 2012 - A new species of Melanospora on truffles from China. Mycologia 104(6), 1433-1442.

Farr DF, Bills GF, Chamuris GP, Rossman AY. 1989 - Fungi on plants and plant prodducts in the United States. Minnesota, 1252.

Fitzpatrick HM. 1923 - Monograph of the Nitschkieae. Mycologia 15(1), 23-44.

Fitzpatrick HM. 1924 - The genus Fracchiaea. Mycologia 16(3), 101-114.

Flakus A, Etayo J, Miadlikowska J, Lutzoni F et al. 2019 - Biodiversity assessment of ascomycetes inhabiting Lobariella lichens in Andean cloud forests led to one new family, three new genera and 13 new species of lichenicolous fungi. Plant and Fungal Systematics 64(2), 283-344.

Fuckel KWGL. 1864 - Fungi Rhenani Exsiccati. Fasc. 10, no. 901-no. 1000.

Fuckel L. 1870a - Symbolae Mycologicae. Jahrb Nassauischen Ver Naturk 23-24, 1-459.

Fuckel L. 1870b - Symbolae mycologicae. Beiträge zur Kenntniss der Rheinischen Pilze. Jahrbücher des Nassauischen Vereins für Naturkunde 23-24, 1-459.

Gams W. 2000 - Phialophora and some similar morphologically little-differentiated anamorphs of divergent ascomycetes. Studies in Mycology, 187-200.

Gams W, Stielow B, Gräfenhan T, Schroers H-J. 2019 - The ascomycete genus Niesslia and associated monocillium-likeanamorphs. Mycological Progress 18(1-2), 5-76.

García D, Stchigel AM, Guarro J. 2002 - A new species of Syspastospora from tropical soils. Mycologia 94(5), 862-865.

García D, Stchigel AM, Guarro J. 2004 - Two new species of Sphaerodes from Spanish soils. Studies in Mycology 50, 63-68.

Hafellner J. 2015 - Lichenicolous Biota (Nos 201-230). Fritschiana (Graz) 80, 21-41. 
Hapuarachchi KK, Karunarathna SC, Phengsintham P, Yang HD et al. 2019 - Ganodermataceae (Polyporales): Diversity in Greater Mekong Subregion countries (China, Laos, Myanmar, Thailand and Vietnam). Mycosphere 10(1), 221-309.

Hara K. 1913 - Fungi on Japanese bamboo. II. Botanical Magazine Tokyo 27, 245-256.

Hawksworth DL. 1975 - Chaetoceratostoma Turc. \& Maffei, a genus to be rejected. Transactions of the British Mycological Society 64(3), 447-453.

Hawksworth DL, Udagawa S. 1977 - Contributions to a monograph of Microthecium. Transactions of the Mycological Society of Japan 18, 143-154.

Hawksworth DL. 1980 - Notes on some fungi occurring on Peltigera, with a key to accepted species. Transactions of the British Mycological Society 74(2), 363-386.

Hawksworth DL, Kirk PM, Sutton BC, Pegler DN. 1995 - Ainsworth \& Bisby's Dictionary of the Fungi. 8th edn CAB International. International Mycological Institute.

Hernández-Restrepo M, Gené J, Castañeda-Ruiz RF, Mena-Portales J et al. 2017 - Phylogeny of saprobic microfungi from Southern Europe. Studies in Mycology 86, 53-97.

Hibbett DS, Binder M, Bischoff JF, Blackwell M et al. 2007 - A higher-level phylogenetic classification of the Fungi. Mycological research 111(5), 509-547.

Hoch H. 1977 - Mycoparasitic relationships: Gonatobotrys simplex parasitic on Alternaria tenuis. Phytopathology 67(19771), 309-314.

Hongsanan S, Maharachchikumbura SSN, Hyde KD, Samarakoon MC et al. 2017 - An updated phylogeny of Sordariomycetes based on phylogenetic and molecular clock evidence. Fungal diversity 84, 25-41.

Horie Y, Udagawa S-1, Cannon P. 1986 - Four new Japanese species of the Ceratostomataceae (Ascomycetes). Mycotaxon 25(1), 229-245.

Huang SK, Hyde KD, Mapook A, Maharachchikumbura SSN et al. 2021 - Taxonomic studies of some often over-looked Diaporthomycetidae and Sordariomycetidae. Fungal diversity, in process.

Huelsenbeck JP, Rannala B. 2004 - Frequentist properties of bayesian posterior probabilities of phylogenetic trees under simple and complex substitution models. Systematic Biology 53(6), 904-913.

Huhndorf SM, Fernández FA, Candoussau F. 1999 - Two new species of Synaptospora. Sydowia 51: 176-182.

Huhndorf SM, Miller AN, Fernández FA. 2004a - Molecular systematics of the Sordariales: the order and the family Lasiosphaeriaceae redefined. Mycologia 96(2), 368-387.

Huhndorf SM, Miller AN, Fernández FA. 2004b - Molecular systematics of the Coronophorales and new species of Bertia, Lasiobertia and Nitschkia. Mycological Research 108(12), 13841398.

Hyde KD, Nakagiri A. 1992 - Intertidal fungi from Australia. The genus Swampomyces including S. triseptatus sp. nov. Sydowia 44, 122-130.

Hyde KD, Hongsanan S, Jeewon R, Bhat DJ et al. 2016 - Fungal diversity notes 367-490: taxonomic and phylogenetic contributions to fungal taxa. Fungal Diversity 80, 1-270.

Hyde KD, Maharachchikumbura SSN, Hongsanan S, Samarakoon MC et al. 2017 - The ranking of fungi: a tribute to David L. Hawksworth on his 70th birthday. Fungal Diversity 84(1), 1-23.

Hyde KD, Danushka S, Tennakoon DS, Jeewon R et al. 2019 - Fungal diversity notes 1036-1150: taxonomic and phylogenetic contributions on genera and species of fungal taxa. Fungal Diversity 96, 1-242.

Hyde KD, Chethana KWT, Jayawardena RS, Luangharn T et al. 2020a - The rise of mycology in Asia. ScienceAsia 46S, 1-11.

Hyde KD, de Silva NI, Jeewon R, Bhat DJ et al. 2020b - AJOM new records and collections of fungi: 1-100. Asian Journal of Mycology 3, 22-294.

Hyde KD, Dong Y, Phookamsak R, Jeewon R et al. 2020c - Fungal diversity notes 1151-1276: taxonomic and phylogenetic contributions on genera and species of fungal taxa. Fungal diversity 100, 5-277. 
Hyde KD, Jeewon R, Chen YJ, Bhunjun CS et al. 2020d - The numbers of fungi: is the descriptive curve flattening? Fungal diversity 103, 219-271.

Hyde KD, Norphanphoun C, Maharachchikumbura SSN, Bhat DJ et al. 2020e - Refined families of Sordariomycetes. Mycosphere, 11(1), 305-1059.

Index Fungorum. 2021 - http://www.indexfungorum.org/-Name/Names.asp.

Jaklitsch WM, Voglmayr H. 2011 - Stromatonectria gen. nov. and notes on Myrmaeciella. Mycologia 103(2), 431-440.

Jaklitsch WM, Voglmayr H. 2012 - Phylogenetic relationships of five genera of Xylariales and Rosasphaeria gen. nov. (Hypocreales). Fungal Diversity 52, 75-98.

Jayawardena RS, Hyde KD, Chethana KWT, Daranagama DA et al. 2018 - Mycosphere notes 102168: Saprotrophic fungi on Vitis in China, Italy, Russia and Thailand. Mycosphere 9(1), 1114.

Jeng RS, Cain RF. 1977 - Rhytidospora, a new cleistocarpous genus of the Melanosporaceae. Mycotaxon 5(1), 278-282.

Jones EBG, Suetrong S, Cheng WH, Rungjindamati N et al. 2014 - An additional fungal lineage in the Hypocreomycetidae (Falcocladium species) and the taxonomic re-evaluation of Chaetosphaeria chaetosa and Swampomyces species, based on morphology, ecology and phylogeny. Cryptogamie, Mycologie 35(2), 119-138.

Jones EBG, Suetrong S, Sakayaroj J, Bahkali AH et al. 2015 - An updated classification of marine Ascomycota, Basidiomycota, Blastocladiomycota and Chytridiomycota. Fungal Diversity 73, $1-72$.

Karsten PA. 1873 - Mycologia fennica. Pars secunda. Pyrenomycetes. Bidrag till Kännedom av Finlands Natur och Folk 23, 1-252.

Keissler Kv. 1930 - Rabenhorst's Kryptogamen-Flora, Pilze - Die Flechtenparasiten. 2(8), 1-712.

Kepler RM, Luangsa-Ard JJ, Hywel-Jones NL, Quandt CA et al. 2017 - A phylogenetically-based nomenclature for Cordycipitaceae (Hypocreales). IMA fungus 8(2), 335-353.

Kirk PM, Cannon PF, Minter DW, Stalpers JA. 2008 - Ainsworth and Bisby's Dictionary of The Fungi. 10th edition. Wallingford, UK: CAB International.

Kirschstein W. 1939 - Über neue, seltene und kritische Ascomyceten und Fungi imperfecti. II. Annales Mycologici 37, 88-140.

Koch J, Jones EBG, Moss ST. 1983 - Groenhiella bivestia, gen. et sp. nov., a lignicolous marine fungus from Denmark. Botanica Marina 26, 265-270.

Kohlmeyer J, Volkmann-Kohlmeyer B. 1987 - Marine fungi from Belize with a description of two new genera of ascomycetes. Botanica Marina 30, 195-204.

Kohlmeyer J, Volkmann-Kohlmeyer B. 1989 - Hawaiian marine fungi, including two new genera of Ascomycotina. Mycological Research 92(4), 410-421.

Kohlmeyer J, Volkmann-Kohlmeyer B, Eriksson OE. 1997 - Fungi on Juncus roemerianus. 9. New obligate and facultative marine Ascomycotina. Botanica Marina 40, 291-300.

Körber GW. 1865 - Parerga lichenologica. Ergänzungen zum Systema lichenum Germaniae, 385501.

Krug JC, Jeng RS. 1979 - Rhytidospora and Pteridiosperma, gen. nov. (Melanosporaceae). Mycotaxon 10(1), 41-45.

Léveillé DM. 1847 - Mycétologie. Orbigny Dictionnaire Universel d'Histoire Naturelle. Mycologie 8, 454-496.

Lombard L, Van der Merwe NA, Groenewald JZ, Crous PW. 2015 - Generic concepts in Nectriaceae. Studies in Mycology 80, 189-245.

Lumbsch HT, Huhndorf SM. 2007 - Outline of ascomycota-2007. Myconet 13, 1-58.

Lumbsch HT, Huhndorf SM. 2010 - Myconet Volume 14. Part One. Outline of Ascomycota 2009. Part Two. Notes on Ascomycete Systematics. Nos. 4751-5113. Fieldiana Life and Earth Sciences 2010(1), 1-64.

Lundqvist N. 1972 - Nordic Sordariaceae s. lat. Symbolae Botanicae Upsalliensis 20, 1-374. 
Luo ZL, Hyde KD, Liu JK, Maharachchikumbura SSN et al. 2019 - Freshwater Sordariomycetes. Fungal diversity 99, 451-660.

Maharachchikumbura SSN, Hyde KD, Jones EBG, McKenzie EHC et al. 2015 - Towards a natural classification and backbone tree for Sordariomycetes. Fungal Diversity 72, 199-301.

Maharachchikumbura SSN, Hyde KD, Jones EBG, McKenzie EHC et al. 2016 - Families of sordariomycetes. Fungal Diversity 79, 1-317.

Maharachchikumbura SSN, Chen Y, Ariyawansa HA, Hyde KD et al. 2021 - Integrative approaches for species delimitation in Ascomycota. Fungal Diversity. https://doi.org/10.1007/s13225-021-00486-6

Marin-Felix Y, Guarro J, Cano-Lira JF, García D et al. 2018 - Melanospora (Sordariomycetes, Ascomycota) and its relatives. MycoKeys(44), 81-122.

Marin-Felix Y, Miller AN, Cano-Lira JF, Guarro J et al. 2020 - Re-evaluation of the order Sordariales: Delimitation of Lasiosphaeriaceae s. str., and introduction of the new families Diplogelasinosporaceae, Naviculisporaceae, and Schizotheciaceae. Microorganisms 8(9), 1430.

Matsushima T. 1995 - Matsushima Mycological Memoires 8. Matsushima Mycological Memoirs $8,1-44$.

Mugambi GK, Huhndorf SM. 2010 - Multigene phylogeny of the Coronophorales: morphology and new species in the order. Mycologia 102(1), 185-210.

Müller E, von Arx JA. 1955 - Einige Beiträge zur Systematik und Synonymie der Pilze. Phytopathologische Zeitschrift 24, 353-372.

Müller E, von Arx JA. 1962 - Die Gattungen der didymosporen Pyrenomyceten. Beitr. Kryptogamenflora Schweiz 11(2), 1-922.

Müller E, Booth C. 1972 - Generic position of Sphaeria phaeostroma. Transactions of the British Mycological Society 58(1), 73-77.

Müller E, von Arx JA. 1973 - Pyrenomycetes: Meliolales Coronophorales, Sphaeriales. Ainsworth GC, Sparrow FK, Sussman AS, eds Fungi 4A, 87-132.

Müller E, Samuels GJ. 1982 - Anamorphs of pyrenomycetous Ascomycetes. I. Rhamphoria Niessel and Trichosphaerella Bommer, Rousseau \& Saccardo. In Sydowia: Annales mycologici 35, 143-149.

Nannfeldt JA. 1932 - Studien über die Morphologie und Systematik der nichtlichenisierten inoperculaten Discomyceten. . Nova Acta Regiae Societatis Scientiarum Upsaliensis 8(2), 1368.

Nannfeldt JA. 1975 - Stray studies in the Coronophorales (Pyrenomycetes) 1-3. Svensk Botanisk Tidskrift 69, 49-66.

Nannfeldt JA, Santesson R. 1975 - Stray studies in the Coronophorales (Pyrenomycetes) 4-8. Svensk Botanisk Tidskrift 69, 289-335.

Navarro-Rosinés P, Hladun N. 1994 - Datos sobre el género Rhagadostoma (ascomicetes liquenícolas, Sordariales). Bull Soc linn Provence 45, 431-442.

Navarro-Rosinés P, Etayo J, Calatayud V. 1999 - Rhagadostoma collematum sp. nov.(ascomicetes liquenícolas, Sordariales) y nuevos datos para otras especies del género. Bull Soc linn Provence 50, 233-241.

Nitschke T. 1870 - Pyrenomycetes Germanici. 2, 161-320.

Olivier H. 1907 - Les principaux parasites de nos lichens francais. (Suite). Bulletin de l'Académie Internationale de Géographie Botanique 17, 162-176.

Pastirčák M, Pastirčáková K. 2007 - Scopinella solani on graminicolous hosts in Slovakia and the Czech Republic. Mycotaxon 102, 383-387.

Patouillard NT. 1922 - Quelques espèces nouvelles de champignons. Bulletin de la Société Mycologique de France 38(2), 83-87.

Patouillard NT, Lagerheim Gd. 1895 - Champignons de l'Équateur (Pugillus V). Bulletin de la Société Mycologique de France 11(4), 205-234. 
Pem D, Hongsanan S, Doilom M, Tibpromma S et al. 2019a - https://www. dothideomycetes. org: An online taxonomic resource for the classification, identification, and nomenclature of Dothideomycetes. Asian Journal of Mycology 2(1), 287-297.

Pem D, Jeewon R, Bhat DJ, Doilom M et al. 2019b - Mycosphere Notes 275-324: A morphotaxonomic revision and typification of obscure Dothideomycetes genera (incertae sedis). Mycosphere 10(1), 1115-1246.

Penzig AJO, Saccardo PA. 1897 - Diagnoses fungorum novorum in insula Java collectorum. Ser. I. Malpighia 11, 387-409.

Pérez-Ortega S, Halici MEHMET. 2008 - Lasiosphaeriopsis lecanorae sp. nov. (Ascomycota, Nitschkiaceae) on Lecanora polytropa from Spain with a key to the known species of the genus. Mycotaxon 104, 247-251.

Petch T. 1916 - Revisions of Ceylon fungi (Part V). Annals of the Royal Botanic Gardens Peradeniya 6, 307-355.

Petrak F. 1952 - Biciliospora n.gen. eine neue Gattung der Sphaeriales. Sydowia 6(5-6), 429-432.

Petrak F. 1959 - Pseudonectriella n.gen., eine neue Gattung der Nectriaceen aus Pakistan. Sydowia 13(1-6), 127-130.

Phookamsak R, Hyde KD, Jeewon R, Bhat DJ et al. 2019 - Fungal diversity notes 929-1035: taxonomic and phylogenetic contributions on genera and species of fungi. Fungal Diversity 95(1), 1-273.

Poursafar A, Ghosta Y, Javan-Nikkhah M. 2017 - Harzia acremonioides, new species for mycobiota of Iran. Rostaniha 18(1), 104-106.

Quandt CA, Kepler RM, Gams W, Araújo JP et al. 2014 - Phylogenetic-based nomenclatural proposals for Ophiocordycipitaceae (Hypocreales) with new combinations in Tolypocladium. IMA fungus 5(1), 121-134.

Rajeshkumar KK, Rossman AY. 2013 - Taiwanascus samuelsii sp. nov., an addition to the Niessliaceae from the Western Ghats of Kerala, India. IMA Fungus 4(1), 1-4.

Ramaley AW. 2001 - Hyaloseta nolinae, its anamorph Monocillium nolinae, and Niesslia agavacearum, new members of the Niessliaceae, Hypocreales, from leaves of Agavaceae. Mycotaxon 79, 267-274.

Read SJ, Jones EBG, Moss ST, Hyde KD. 1995 - Ultrastructure of asci and ascospores of two mangrove fungi: Swampomyces armeniacus and Marinosphaera mangrovei. Mycological Research 99(12), 1465-1471.

Réblová M. 1999a - Studies in Chaetosphaeria sensu lato I. The genera Chaetosphaerella and Tengiomyces gen. nov. of the Helminthosphaeriaceae. Mycotaxon 70, 387-420.

Réblová M. 1999b - Studies in Chaetosphaeria sensu lato IV. Crassochaeta gen. nov., a new lignicolous genus of the Trichosphaeriaceae. Mycotaxon 71, 45-67.

Réblová M. 2002 - Synaptospora olandica, a new species from Sweden. Sydowia 54(2), 248-255.

Réblová M, Miller AN, Rossman AY, Seifert KA et al. 2016 - Recommendations for competing sexual-asexually typified generic names in Sordariomycetes (except Diaporthales, Hypocreales, and Magnaporthales). IMA fungus 7(1), 131-153.

Rehner SA, Samuels GJ. 1995 - Molecular systematics of the Hypocreales: a teleomorph gene phylogeny and the status of their anamorphs. Canadian Journal of Botany 73, 816-823.

Rogerson CT. 1970 - The Hypocrealean Fungi (Ascomycetes, Hypocreales). Mycologia 62, 865910.

Rossman AY, Samuels GJ, Rogerson CT, Lowen R. 1999 - Genera of Bionectriaceae, Hypocreaceae and Nectriaceae (Hypocreales, Ascomycetes). Stud Mycol 42, 1-248.

Saccardo PA. 1873a - Mycologiae venetae specimen. Atti della Società veneto-trentina di scienze naturali residente in Padova, 1-336.

Saccardo PA. 1873b - Fungi Veneti novi vel critici. Series I. Nuovo Giornale Botanico Italiano 5, 269-298.

Saccardo PA. 1878 - Enumeratio pyrnomycetum hypocreaceorum. Hucusque cognitorum. Systemate carpologico dispositorum. Michelia 1, 278-355. 
Saccardo PA. 1880 - Fungorum extra-Europaeorum pugillus. Michelia 2(6), 138.

Saccardo PA. 1882a - Sylloge Pyrenomycetum, Vol. I. Sylloge Fungorum 1, 1-768.

Saccardo PA. 1882b - Sylloge fungorum omnium hucusque cognitorum. typis Seminarii 1, 1-766.

Saccardo PA. 1883 - Sylloge Pyrenomycetum, vol. II. Sylloge Fungorum, 2, 1-813.

Saccardo PA, Berlese AN. 1885 - Miscellania mycologica. Series II. Atti dell'Istituto Veneto Scienze 3, 711-742.

Saccardo PA. 1886 - Sylloge Hyphomycetum. Sylloge Fungorum 4, 1-807.

Saccardo PA. 1891 - Supplementum Universale, Pars I. Agaricaceae-Laboulbeniaceae. Sylloge Fungorum 9, 1-1141.

Saccardo PA, Berlese AN. 1896 - Una nuova malattia del Frumento. Rivista di Patologia Vegetale 4, 56-66.

Saccardo PA. 1918 - 1. Fungi Singaporenses Bakeriani. 2. Fungi Abellinenses novi. Bolletino dell'Orto Botanico Regia dell'Universita de Napoli 6, 39-73.

Sakayaroj J, Pang KL, Jones EBG, Phongpaichit S et al. 2005 - A systematic reassessment of the marine ascomycetes Torpedospora and Swampomyces. Botanica Marina 48(5), 395-406.

Samuels GJ. 1983 - Ascomycetes of New Zealand 4. Valetoniella crucipila Höhnel and Trichosphaerella tuberculata sp. nov., two members of the Trichosphaeriaceae with pseudoamyloid ascospores. New Zealand journal of botany 21(2), 157-161.

Samuels GJ, Barr ME. 1997 - Notes on and additions to the Niessliaceae (Hypocreales). Canadian Journal of Botany 75(12), 2165-2176.

Samuels GJ, Candoussau F, Magni J-F. 1997 - Fungicolous pyrenomycetes 2. Ascocodinaea, gen. nov. and reconsideration of Litschaueria. Mycologia 89, 156-162.

Sanchez RM, Giordano L, Anderson FE, Bianchinotti MV. 2012 - A new species of Scopinella from pampas grass in Argentina. Mycotaxon 122, 265-270.

Scheckhuber CQ, Osiewacz HD. 2008 - Podospora anserina: a model organism to study mechanisms of healthy ageing. Molecular Genetics and Genomics 280(5), 365-374.

Scheuer C. 1993 - Cryptoniesslia setulosa gen. et sp. nov. Mycological Research 97, 543-546.

Schoch CL, Sung GH, Volkmann-Kohlmeyer B, Kohlmeyer J, Spatafora JW. 2007 - Marine fungal lineages in the Hypocreomycetidae. Mycological Research 111(2), 154-162.

Schultes NP, Murtishi B, Li DW. 2017 - Phylogenetic relationships of Chlamydomyces, Harzia, Olpitrichum, and their sexual allies, Melanospora and Sphaerodes. Fungal biology 121(10), 890-904.

Secretariat of Convention on Biological Diversity. 2007 - Guide to the Global Taxonomy Initatiative, CBD Technical Series 27. https://www.cbd.int/gti/taxonomy.shtml

Seifert KA, Morgan-Jones G, Gams W, Kendrick B. 2011 - The Genera of Hyphomycetes. Paper presented at the CBS KNAW Fungal Biodiversity Centre Utrecht, The Netherlands.

Senanayake IC, Rathnayaka AR, Marasinghe DS, Calabon MS et al. 2020 - Morphological approaches in studying fungi: collection, examination, isolation, sporulation and preservation. Mycosphere 11(1), 2678-2754.

Sivanesan A. 1974 - Two new genera of Coronophorales with descriptions and key. Transactions of the British Mycological Society 62(1), 35-43.

Sivanesan A, Chang HS. 1997 - A lignicolous ascomycete, Taiwanascus tetrasporus gen nov. et sp. nov., and a new family Taiwanascaceae. Mycological Research 101(2), 176-178.

Smyk LV. 1981 - Griby poriadku Coronophorales u Mikoflory Ukraniy. Ukraïns'kii Bot Zhurn 38(6), 46-49.

Spegazzini C. 1888 - Fungi Guarinitici. Pugillus II. Anales de la Sociedad Científica Argentina 26(1), 5-74.

Spegazzini C. 1908 - Hongos de la yerba mate. Anales del Museo Nacional de Historia Natural Buenos Aires 17(10), 111-141.

Spegazzini C. 1909 - Mycetes Argentinenses. Series IV. Anales del Museo Nacional de Historia Natural Buenos Aires 3(12), 257-458. 
Spegazzini C. 1922 - Fungi Paraguayenses. Anales del Museo Nacional de Historia Natural Buenos Aires 31, 355-450.

Spegazzini C. 1926 - Contribución al conocimiento de la flora micológica de las Sierras de Córdoba. Boletín de la Academia Nacional de Ciencias en Córdoba 29(2-3), 113-190.

Starbäck K. 1894 - Studier i Elias Fries' svampherbarium. I "Sphaeriaceae imperfecte cognitae". Bihang till Kungliga svenska Vetenskaps-Akademiens Handlingar 19(2), 1-114.

Starbäck K. 1899 - Ascomyceten der ersten Regnell'schen Expedition. I. Bihang till Kungliga svenska Vetenskaps-Akademiens Handlingar 25(1), 1-68.

Strasser PP. 1911 - V. Nachtrag zur Pilzflora des Sonntagberg (Nied.-Öster.). Ann Mycol 11, 7493.

Subramanian CV, Sekar G. 1990 - Coronophorales from India-a monograph. Kavaka 18, 19-90.

Subramanian CV. 1993 - Veramyces, a new hyphomycete genus from Kumaon Himalayas. Czech Mycology 47, 3-5.

Takada M. 1973 - Notes on soil-bore Ascomycetes. Bulletin of the National Science Museum, Tokyo 16(3), 521-535.

Tang AMC, Jeewon R, Hyde KD. 2007 - Phylogenetic utility of protein (RPB2, $\beta$-tubulin) and ribosomal (LSU, SSU) gene sequences in the systematics of Sordariomycetes (Ascomycota, Fungi). Antonie van Leeuwenhoek 91(4), 327-349. Doi 10.1007/s10482-006-9120-8

Teng SC. 1934 - Notes on Sphaeriales from China. Sinensia 4, 359-433.

Teng SJ. 1938 - Additional fungi from China VIII. Sinensia 9, 219-258.

Theissen F. 1910 - Fragmenta Brasilica III. Annales Mycologici 8(4), 452-463.

Theissen F. 1917 - Über Tympanopsis und einige andere Gattungstypen. Annales Mycologici 15, 269-277.

Tibpromma S, Hyde KD, McKenzie EHC, Bhat DJ et al. 2018 - Fungal diversity notes 840-928: micro-fungi associated with Pandanaceae. Fungal Diversity 93, 1-160.

Tode HJ. 1791 - Fungi Mecklenburgenses Selecti (vol. 2). Luneburgi: I.F.G. Lemke.

Tretiach M. 2002 - Niesslia robusta, a new lichenicolous fungus on Tephromela grumosa from Tuscany, Italy. Nova Hedwigia 75, 357-365.

Tsui CKM, Hyde KD, Hodgkiss IJ. 2001 - Paraniesslia tuberculata gen. et sp. nov., and news records of Clypeosphaeria, Leptosphaeria and Astrosphaeriella in Hong Kong freshwater habitats. Mycologia 93, 1002-1009.

Tulasne LR. 1857 - Note sur les Isaria et Sphaeria entomogenes. Annales des Sciences Naturelles Botanique 4(8), 35-43.

Tulasne LR, Tulasne C. 1865 - Selecta Fungorum Carpologia. 3 (Paris: Imperial).

Udagawa SI, Cain RF. 1969 - Notes on the genus Microthecium. Canadian Journal of Botany 47(12), 1915-1933.

Vakili NG. 1989 - Gonatobotrys simplex and its teleomorph, Melanospora damnosa. Mycological Research 93(1), 67-74.

Valldosera M, Guarro J. 1994 - Two new coprophilous ascomycetes from South America. Nova Hedwigia 58(3-4), 447-451.

van Geel B, Aptroot A. 2006 - Fossil ascomycetes in Quaternary deposits. Nova Hedwigia 82(3), 313-330.

Vasilyeva L, Chernyshev A, Stephenson SL. 2010 - Pyrenomycetes of the Russian Far East 4: family Nitschkiaceae (Coronophorales, Ascomycota). Mycologia 102(1), 233-247.

Vasilyeva LN. 1990 - New pyrenomycetous species from Kunashir. Mikologiya i Fitopatologiya 24, 207-210.

Vasilyeva LN, Chernyshev AV, Stephenson SL. 2012 - Neochaetosphaerella thaxteriospora gen. et sp. nov. and Tympanopsis texensis sp. nov. (Coronophorales, Ascomycota) from Texas, USA. Fungal Diversity 52(1), 191-196.

Vasilyeva LN, Chernyshev AV, Stevenson SL, Hyde KD. 2013 - Tortulomyces thailandicus gen. et sp. nov. and Nitschkia siamensis sp. nov.(Coronophorales, Ascomycota) from northern Thailand. mycoscience 54(2), 110-115. 
von Arx JA, Müller E. 1954 - Die Gattungen der amerosporen Pyrenomyceten. Beiträge zur Kryptogamenflora der Schweiz 11(1), 1-434.

von Höhnel F. 1903 - Mycologische Fragmente (Fortsetzung). Annales Mycologici 1(6), 522-534.

von Höhnel F. 1907 - Fragmente zur Mykologie: IV. Mitteilung (Nr. 156 bis 168). Sitzungsberichte der Kaiserlichen Akademie der Wissenschaften Math-naturw Klasse Abt I $116,615-647$.

von Höhnel F. 1909a - Fragmente zur Mykologie: VIII. Mitteilung (Nr. 354 bis 406). Sitzungsberichte der Kaiserlichen Akademie der Wissenschaften Math-naturw Klasse Abt I $118,1157-1246$.

von Höhnel F. 1909b - Fragmente zur Mykologie: IX. Mitteilung (Nr. 407 bis 467). Sitzungsberichte der Kaiserlichen Akademie der Wissenschaften Math-naturw Klasse Abt I 118, 1461-1552.

von Höhnel F. 1918 - Mykologische fragmente. Ann mycol 16, 35-174.

Vu D, Groenewald M, De Vries M, Gehrmann T et al. 2019 - Large-scale generation and analysis of filamentous fungal DNA barcodes boosts coverage for kingdom fungi and reveals thresholds for fungal species and higher taxon delimitation. Studies in mycology 92, 135154.

Walker JC, Minter DW. 1981 - Taxonomy of Nematogonum, Gonatobotrys, Gonatobotryum and Gonatorrhodiella. Transactions of the British Mycological Society 77(2), 299-319.

Wanasinghe DN, Phukhamsakda C, Hyde KD, Jeewon R et al. 2018 - Fungal diversity notes 709839: taxonomic and phylogenetic contributions to fungal taxa with an emphasis on fungi on Rosaceae. Fungal diversity 89(1), 1-236.

Wang XW, Houbraken J, Groenewald JZ, Meijer M et al. 2016 - Diversity and taxonomy of Chaetomium and chaetomium-like fungi from indoor environments. Studies in mycology 84, 145-224.

Wang XW, Bai FY, Bensch K, Meijer M et al. 2019a - Phylogenetic re-evaluation of Thielavia with the introduction of a new family Podosporaceae. Studies in Mycology 93, 155-252.

Wang XW, Yang FY, Meijer M, Kraak B et al. 2019b - Redefining Humicola sensu stricto and related genera in the Chaetomiaceae. Studies in mycology 93, 65-153.

Wang YB, Wang Y, Fan Q, Duan DE et al. 2020 - Multigene phylogeny of the family Cordycipitaceae (Hypocreales): new taxa and the new systematic position of the Chinese cordycipitoid fungus Paecilomyces hepiali. Fungal Diversity 103, 1-46.

Whaley JW, Barnett H. 1963 - Parasitism and nutrition of Gonatobotrys simplex. Mycologia 55(2), 199-210.

Wijayawardene NN, Hyde KD, Lumbsch HT, Liu JK et al. 2018 - Outline of ascomycota: 2017. Fungal Diversity 88, 167-263.

Wijayawardene NN, Hyde KD, Al-Ani LKT, Tedersoo L et al. 2020 - Outline of Fungi and fungus-like taxa. Mycosphere 11(1), 1060-1456.

Wijesinghe SN, Camporesi E, Wanasinghe DN, Maharachchikumbura SSN et al. 2021 - A dynamic online documentation of Italian ascomycetes with hosts and substrates: www. italianmicrofungi. org. Asian Journal of Mycology 4(1), 10-18.

Winter G. 1885 - Rabenhorst's Kryptogamen-Flora. Pilze-Ascomyceten, Edn 2 1(2), 193-528.

Winter G. 1887a - Die Pilze, Ascomyceten: Gymnoasceen und Pyrenomyceten. In: Rabenhorst's Kryptogamen-Flora Deutschl, Öster und der Schweiz, Band 2(1), 1-928.

Winter G. $1887 \mathrm{~b}$ - Die Pilze, II. Ascomyceten. In Rabenhorst's Kryptogamenflora von Deutschland, Oesterreich und der Schweiz 1(2), 1-928.

Yuan HS, Lu X, Dai YC, Hyde KD et al. 2020 - Fungal diversity notes 1277-1386: taxonomic and phylogenetic contributions to fungal taxa. Fungal diversity 104, 1-266.

Zhang N, Blackwell M. 2002 - Molecular phylogeny of Melanospora and similar pyrenomycetous fungi. Mycological Research 106(2), 148-155.

Zhang N, Castlebury LA, Miller AN, Huhndorf SM et al. 2006 - An overview of the systematics of the Sordariomycetes based on a four-gene phylogeny. Mycologia 98(6), 1076-1087. 
Zukal H. 1885 - Ueber einige neue Pilze, Myxomyceten und Bakterien. Verhandlungen der Kaiserlich-Königlichen Zoologisch-Botanischen Gesellschaft in Wien 35, 333-342. 